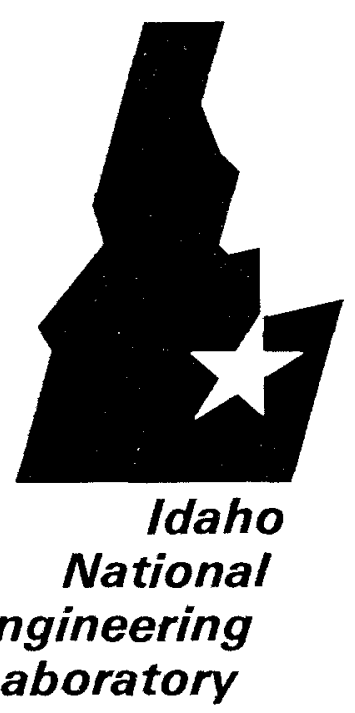

Managed by the U.S. Department of Energy
EGG-NRE-10754

November 1993

CRITICALITY SAFETY EVALUATION FOR TRU WASTE IN STORAGE AT THE RWMC
Maria E. Shaw

J. Blair Briggs

Carol A. Atkinson

Glen J. Briscoe

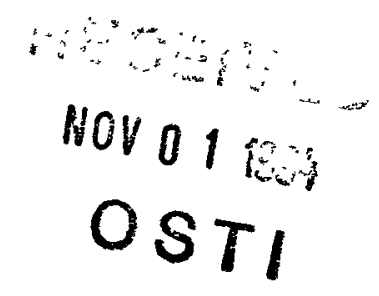





\title{
CRITICALITY SAFETY EVALUATION FOR TRU WASTE IN STORAGE AT THE RWMC
}

\author{
Maria E. Shaw \\ J. Blair Briggs \\ Carol A. Atkinson \\ Glen J. Briscoe
}

Published November 1993

INEL

\section{EG\&G Idaho}

Idaho Falls, ID 84315
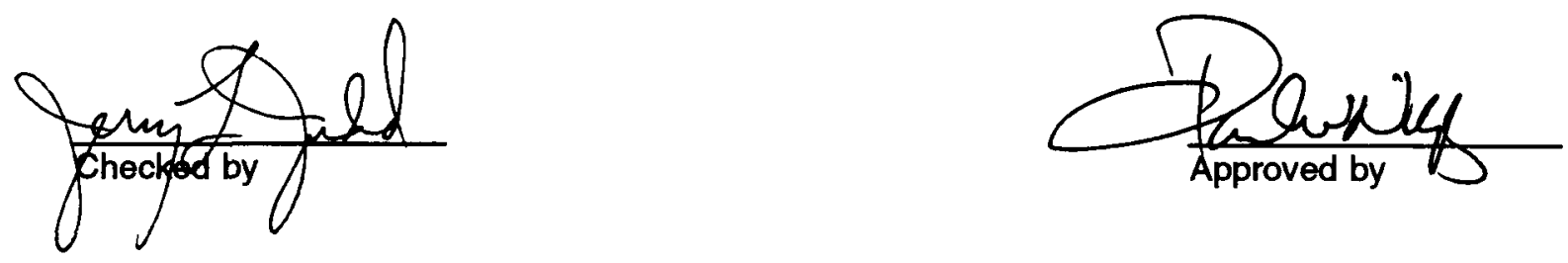

Prepared for the

U.S. Department of Energy

Idaho Operations Office

Under DOE Contract No. DE-AC07-76D01570 


\begin{abstract}
Stored containers (drums, boxes, and bins) of transuranic waste at the Radioactive Waste Management Complex (RWMC) facility located at the Idaho National Engineering Laboratory (INEL) were evaluated based on inherent neutron absorption characteristics of the waste materials. It was demonstrated that these properties are sufficient to preclude an accidental criticality accident at the actual fissile levels present in the waste stored at the RWMC. Based on the database information available, the results reported herein confirm that the waste drums, boxes, and bins currently stored at the RWMC will remain safely subcritical if rearranged, restacked, or otherwise handled. Acceptance criteria for receiving future drum shipments were established based on fully infinite systems.
\end{abstract}




\section{ACKNOWLEDGMENTS}

The authors wish to acknowledge the contributions of several individuals. To assist with the validation section, MCNP calculations were performed by Virginia F. Dean and SCAMP calculations with COMBINE-generated cross section data (ENDF/B, Version 5) were performed by Brian L. Rushton. Kim Culbertson contributed the database summaries which are included in Appendix $D$. Independent review and numerical checking to verify the accuracy of code input and output was performed primarily by Mark N. Neeley. We appreciate the efforts of each of these individuals.

\section{DISCLAIMER}

This report was prepared as an account of work sponsored by an agency of the United States Government. Neither the United States Government nor any agency thereof, nor any of their employees, makes any warranty, express or implied, or assumes any legal liability or responsibility for the accuracy, completeness, or usefulness of any information, apparatus, product, or process disclosed, or represents that its use would not infringe privately owned rights. Reference herein to any specific commercial product, process, or service by trade name, trademark, manufacturer, or otherwise does not necessarily constitute or imply its endorsement, recommendation, or favoring by the United States Government or any agency thereof. The views and opinions of authors expressed herein do not necessarily state or reflect those of the United States Government or any agency thereof. 



\section{TABLE OF CONTENTS}

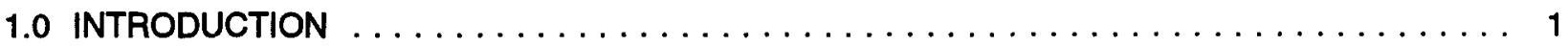

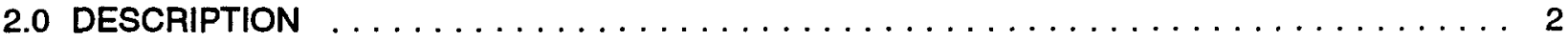

3.0 REQUIREMENTS DOCUMENTATION $\ldots \ldots \ldots \ldots \ldots \ldots \ldots \ldots \ldots \ldots \ldots \ldots$

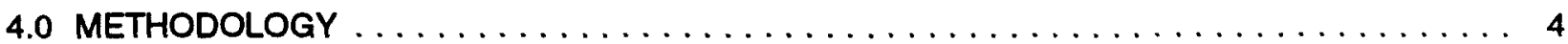

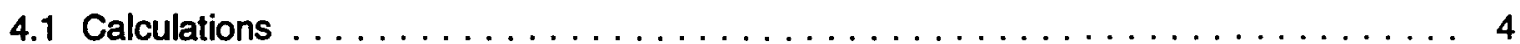

4.2 Validation $\ldots \ldots \ldots \ldots \ldots \ldots \ldots \ldots \ldots \ldots \ldots \ldots \ldots \ldots \ldots \ldots$

5.0 DISCUSSION OF CONTINGENCIES $\ldots \ldots \ldots \ldots \ldots \ldots \ldots \ldots \ldots \ldots \ldots$

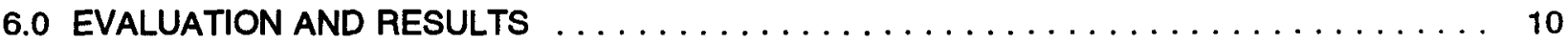

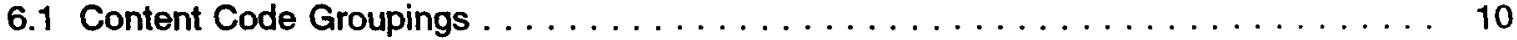

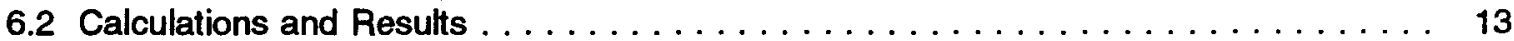

6.2.1 Fully Infinite Systems and Comparison of Results to the Database . . . . . 13

6.2.2 Effects of Discretely Modeled Drums . . . . . . . . . . . . . . . . . . 20

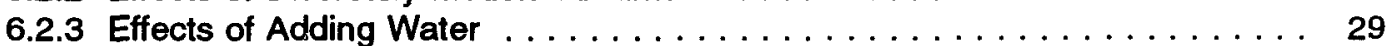

6.2.4 Effects of Heterogeneity . . . . . . . . . . . . . . . . . . . . 31

6.2.5 Effects of Density and Distribution of Material $\ldots \ldots \ldots \ldots \ldots \ldots$

6.4 Single Heavily Loaded Drums . . . . . . . . . . . . . . . . . . . . . 42

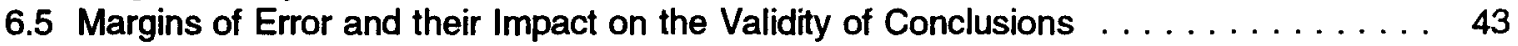

7.0 DESIGN FEATURES (PASSIVE \& ACTIVE) AND ADMINISTRATIVELY CONTROLLED

LIMITS AND REQUIREMENTS $\ldots \ldots \ldots \ldots \ldots \ldots \ldots \ldots \ldots \ldots \ldots \ldots \ldots$

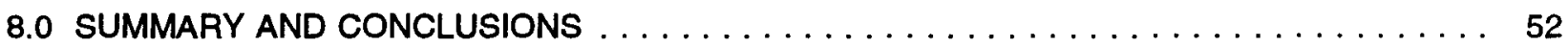

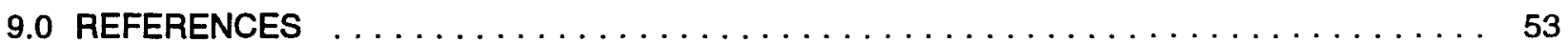

APPENDIX A: MATERIALS AND COMPOSITIONS $\ldots \ldots \ldots \ldots \ldots \ldots \ldots \ldots \ldots \ldots$

APPENDIX B: TYPICAL SCAMP, CSAS, MCNP, KENO, AND COMBINE INPUT LISTINGS . . . . 69

APPENDIX C: TRANSURANIC WASTE CONTENT CODES DESCRIPTIONS $\ldots \ldots \ldots \ldots$

APPENDIX D: SUMMARY OF DATABASE INFORMATION BY MATRIX GROUPS $\ldots \ldots \ldots 131$

APPENDIX E: CALCULATIONAL CONFIGURATION OF EXISTING MORE HEAVILY LOADED

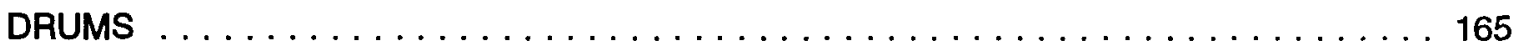

APPENDIX F: INDEPENDENT REVIEW $\ldots \ldots \ldots \ldots \ldots \ldots \ldots \ldots \ldots \ldots \ldots \ldots$ 


\section{LIST OF FIGURES}

1. Calculated $\mathrm{k}_{\mathrm{o}}$ vs. ${ }^{239} \mathrm{Pu}$ concentration in graphite, $\mathrm{MgO}, \mathrm{SiO}_{2}$, and $\mathrm{Al}_{2} \mathrm{O}_{3} \ldots \ldots \ldots$

2. Calculated $k_{\infty}$ vs. ${ }^{239} \mathrm{Pu}$ concentration in $\mathrm{Al}$, concrete, cellulose, water, and polyethylene . . . 17

3. Sketch of 55 gallon waste storage drum showing dimensions and modeled unit cell . . . . . 21

4. Calculated $k_{\text {off }}$ vs. ${ }^{239} \mathrm{Pu}$ concentration in graphite for discretely modeled drums . . . . . . 27

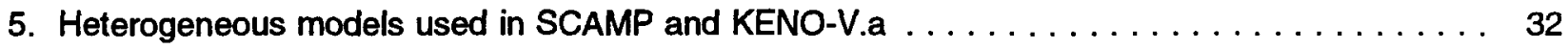

6. Distribution of ${ }^{239} \mathrm{Pu}$ in assayed drums $\ldots \ldots \ldots \ldots \ldots \ldots \ldots \ldots \ldots \ldots \ldots \ldots \ldots$ 


\section{LIST OF TABLES}

1. Code comparisons for initial critical concentrations of ${ }^{239} \mathrm{Pu}$ in waste $\ldots \ldots \ldots \ldots \ldots$

2. Content code grouping for calculations $\ldots \ldots \ldots \ldots \ldots \ldots \ldots \ldots \ldots \ldots \ldots \ldots \ldots \ldots \ldots \ldots \ldots \ldots$

3. Results of SCAMP and KENO-V.a calculations used to determine the calculated critical concentration of ${ }^{239} \mathrm{Pu}$ in various matrix materials $\ldots \ldots \ldots \ldots \ldots \ldots \ldots \ldots$

4. Comparison of calculated threshold concentrations with database information $\ldots \ldots \ldots$

5. Summary of calculations showing the effects of discretely modeled drums and large finite

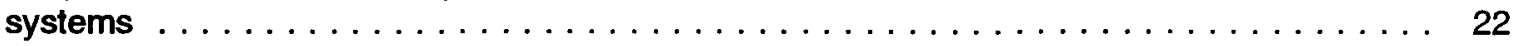

6. Summary of calculations for drums containing graphite with high concentrations of ${ }^{239} \mathrm{Pu}$ used to determine the thickness of surrounding matrix material necessary to eliminate interaction effects between arrays of drums. $\ldots \ldots \ldots \ldots \ldots \ldots \ldots \ldots \ldots \ldots \ldots \ldots$

7. Summary of calculations for drums containing graphite waste used to determine the critical concentration when discretely modeling drums.

8. Summary of calculations for drums containing graphite with threshold concentrations of ${ }^{239} \mathrm{Pu}$ as determined by explicitly modeling drums $\ldots \ldots \ldots \ldots \ldots \ldots \ldots \ldots \ldots \ldots$

9. Results of KENO-V.a calculations showing the effects of adding water to $\mathrm{SiO}_{2}$ systems. . . . 30

10. Results of SCAMP calculations showing the effects of adding water to graphite systems. . . . 30

11. SCAMP or CSAS results showing the effects of layering materials. $\ldots \ldots \ldots \ldots \ldots$

12. Results of SCAMP calculations showing the effects of non-homogeneous distribution of

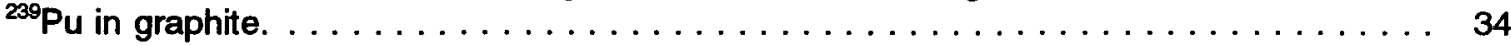

13. Summary of KENO-V.a results showing the effects of graphite density and distribution. $\ldots \ldots$. . 37

14. Results of KENO-V.a calculations for maximum concentrations $\ldots \ldots \ldots \ldots \ldots \ldots$

15. Fissile content and concentrations of assayed drums $\ldots \ldots \ldots \ldots \ldots \ldots \ldots$

16. Percentage of drums exceeding $37.5 \%$ the calculated critical values. $\ldots \ldots \ldots \ldots$

17. Acceptance criteria for future receipt of waste. $\ldots \ldots \ldots \ldots \ldots \ldots \ldots \ldots \ldots \ldots \ldots \ldots \ldots$ 


\section{,}




\subsection{INTRODUCTION}

More than 100,000 drums, 10,000 boxes, and 500 bins of radioactive waste are stored at the Radioactive Waste Management Complex (RWMC) facility located at the Idaho National Engineering Laboratory (INEL). The amount of fissile material in each container is generally very small; however, limits on the vertical height to which the containers may be stacked and on the fissile mass per container have been imposed in order to ensure that adequate criticality safety margins are maintained. The approach taken in past evaluations has been to demonstrate that, up to a certain vertical stack height, neutron leakage is sufficiently high to prevent infinite arrays of containers from becoming critical. The fissile material was very conservatively represented in these past evaluations as optimally moderated (water and/or polyethylene) plutonium systems. The containers at the RWMC will always have vertical stacking requirements because of structural and seismic considerations. However, stacking limits and controls imposed because of criticality safety concerns are much more costly to administer. The approach used in this evaluation to establish a basis for criticality safety of the waste containers stored at the RWMC is to demonstrate that the inherent neutron absorption characteristics of the waste materials are sufficient to preclude the possibility of a criticality at the RWMC with any number of containers in any configuration. The purpose of this evaluation is to demonstrate that stacking limits or other imposed handling restrictions are unnecessary by:

1. Demonstrating that the drums, boxes, and bins that are currently stored at the INEL are safe (from a criticality safety viewpoint) in any configuration (including the loss of container integrity) and

2. Establishing criteria for the receipt of containers that might be shipped to the INEL in the future.

Individual drums loaded at relatively high fissile levels do not present a criticality hazard because their occurrence is rare and when identified are isolated from other heavily loaded drums. If a criticality involving heavily loaded drums can be shown to be incredible, drums can be handled in the most efficient and cost-effective way by eliminating the need for controls on allowable container configurations (stack height, array size, intermixing drums, etc.).

This evaluation focuses on the drums, boxes, and bins that were shipped to the INEL from the Rocky Flats Plant. Data on these containers, which includes data on approximately 73,000 drums, 10,000 boxes, and 500 bins, were readily available and may be used to conservatively envelop containers that were shipped from other waste generators. 


\subsection{DESCRIPTION}

The RWMC provides a temporary storage location for containers of transuranic waste and is designed for use until the waste can be shipped to a permanent repository. Operations at the RWMC include storage, shipping, and receiving of radioactive waste from various Department of Energy (DOE) facilities, primarily the Rocky Flats Plant (RFP) near Denver, Colorado. Historically, storage at RWMC has been in soil vaults or bulk pits, with the waste contained in metal drums or wooden bins. The majority of containment is in $\mathbf{5 5}$ gallon drums, some of which are overpacked in $\mathbf{8 3}$ gallon drums.

Waste stored at the INEL originates from several sources within the DOE facilities. Typically, the waste material is contaminated laboratory clothing, equipment, and tools; contaminated soil from spill cleanup; and filters or other debris from maintenance, renovation, or decommissioning projects. Distribution of fissile material inside the containers ranges from mostly homogeneous mixtures of fines or soil to non-uniform configurations resulting from the use of inner containers or absorbent materials.

Waste that is currently received is stored in enclosed facilities where it is stacked on concrete or asphalt pads with layers of plywood between drums. From 1970 to 1982, drums were stacked on asphalt pads and covered with a two foot layer of soil. Drums are presently stored with various spacing requirements, sometimes in close-packed triangular-pitched arrays. Other containers, such as bins and boxes, are stored in various arrangements at the facility. 


\subsection{REQUIREMENTS DOCUMENTATION}

This analysis is classified as Quality Level A (according to the EG\&G Idaho Quality Manual) and is intended to comply with NQA-1. As required by the Nuclear Engineering Standard Practice, NE-SP-2 ${ }^{\star}$, any operational procedures which result from, or are based on, information contained in this report must be reviewed by Reactor and Radiation Physics personnel to ensure that the technical information given in this Criticality Safety Evaluation has been properly incorporated into the procedures.

Based on the analysis presented in this report, the safety of waste storage at the RWMC will ultimately depend on the concentration of plutonium in the waste. According to DOE ID 5480.5A Chapter I Section 4.b(1)(c), Concentration Control, "For a system to be considered critically safe by concentration alone, the fissile isotope concentration shall be limited to $75 \%$ of the critical concentration for a geometrically infinite system..." Limits established by this document comply with this requirement. There are no other requirements that are unique to this evaluation.

-Criticality Safety Evaluations and Design Calculations, Criticality Safety Analysis Standard Practice for Nuclear Engineering, NE-SP-2, EG\&G Idaho, Idaho National Engineering Laboratory, October, 1991. (Intemal document available for viewing upon request at the Idaho National Engineering Laboratory.) 


\subsection{METHODOLOGY}

The calculations performed for this evaluation were designed with two specific objectives. The first objective was to demonstrate that all of the containers presently in storage at the RWMC are safe from criticality when stored in any configuration. Accomplishment of this objective was based on the concentrations of fissile material actually present, even if concentrations in individual containers exceed the newly established acceptance criteria. The second objective was to determine simplified criteria for the receipt of future shipments of containers. This was accomplished by determining a minimum critical fissile concentration for a fully infinite system of a given waste type. A threshold value or "acceptance criteria" was then established by calculating $75 \%$ of the critical concentration. This value is referred to as an "acceptance criteria" because any number of any size container could be safely accepted for storage and stored in any arrangement provided the contents are within the established criteria. Container acceptance criteria can be simplified in this manner since the calculations are based on fully infinite systems with no credit taken for the neutron absorption properties of the container.

The results of criticality calculations for several concentration ranges of plutonium mixed with non-fissile matrices were compared to the existing database listing information about the stored waste. It was easily demonstrated from the results, that the majority of the containers are of essentially no concern from a criticality safety viewpoint because the concentration of fissile material is so low.

\subsection{Calculations}

Due to the number of containers present and the variety of their contents, the modeling of each individual container is not practical. Simplifications to container contents were made and calculations performed for fully infinite systems of homogeneous ${ }^{239} \mathrm{Pu}$ and matrix material. To increase assurance that the conclusions of this evaluation can be applied confidently to the entire inventory, other models conservatively representing the most heavily loaded containers were utilized.

Several different neutronics codes and cross section data were used for this evaluation. The majority of critical concentrations were found using the results of calculations performed with the onedimensional, discrete ordinates $\left(S_{N}\right)$, transport theory code, SCAMP, ${ }^{b}$ using 16-group Hansen-Roach

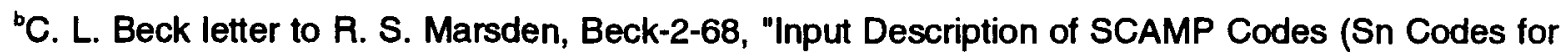
the Analysis of Multigroup Problems)," May 17, 1968. (Internal document available for viewing upon request at the Idaho National Engineering Laboratory.) 
cross sections (Ref. 1). $S_{2}$ calculations were performed for infinite homogeneous systems and $S_{6}$ calculations were performed for heterogeneous systems. Additional calculations necessary to accomplish the objectives of this evaluation were performed with the three-dimensional Monte Carto code, KENO-V.a (Ref. 2), using both 16-group KENO cross section data comprised primarily of Hansen-Roach data and 27-group cross section data based on ENDF/B-IV data (Ref. 3). Calculations intended to verify the original SCAMP results using Hansen-Roach cross sections were performed with the three-dimensional Monte Carlo code, MCNP (Ref. 4), using continuous energy ENDF/B-V cross sections (Ref. 5) and with SCAMP using 16-group ENDF/B-V cross sections generated through the neutron spectrum and cross section generation program, COMBINE (Ref. 6).

\subsection{Validation}

Calculations used to evaluate the majority of drums were performed with Configuration Release A of the one-dimensional, discrete ordinates, transport theory code, SCAMP, on either an HP 9000/720 workstation with Version 8.07 operating system and Version 8.07 of the FORTRAN compiler or on an IBM Model 320 RISC 6000 workstation with the AIX Version 3.1.5 operating system and AIX Version 2.1 of the FORTRAN compiler."

Other calculations were performed using two separate versions of the three-dimensional Monte Carlo code, KENO-V.a. The first version was a stand-alone version using the 16-group KENO cross section data set comprised mainly of Hansen-Roach cross section data. The second was accessed through the Criticality Safety Analytic Sequence (CSAS) Module CSAS25 (Ref. 3) where a problemdependent 27-group cross section data set based on ENDF/B-IV data was generated and used for the KENO-V.a calculations. Both versions of KENO-V.a are available through the SCALE4 collection of codes (Ref. 7). The coding of KENO-V.a itself was identical in both versions.

The KENO code has been used extensively in the criticality safety industry for several years. KENO-V.a is an extension of earlier versions of the KENO code and includes many versatile new geometry capabilities and plot routines to facilitate geometry verification. All KENO-V.a calculations in this evaluation were performed on either an IBM Model 320 RISC 6000 workstation with AIX Version 3.1.5 operating system and Version 2.1 of the FORTRAN compiler, or an HP 9000/720 workstation with Version 8.07 operating system and Version 8.07 of the FORTRAN compiler. Configuration Release

JJ. L. Judd, SCAMP Benchmark Notes, NRRT-N-92-010, May 1992. (Internal document available for viewing upon request at the Idaho National Engineering Laboratory.) 
1.10 of the KENO-V.a code and the associated Hansen-Roach cross section data set were verified for proper operation on these computational platforms by repeating the 25 sample problems that were transmitted with the code. All calculated $k_{\text {eff }}$ values agree well (generally within $1 \%$ ) with the results obtained on the Oak Ridge National Laboratory computer system (Ref. 2).

Hydrogen-moderated plutonium benchmark critical experiments were evaluated with the KENO-V.a code. ${ }^{a}$ These results indicate that a bias in addition to the statistical uncertainties associated with the Monte Carlo calculations is not warranted for hydrogenously moderated systems with H/Pu ratios ranging from about 100 to 1200 . Threshold values in this report were for hydrogenously moderated systems with much higher $\mathrm{H} / \mathrm{Pu}$ ratios (near 3700) and benchmark critical data are not available for systems of this nature. Extensions to the range of applicability are justified by performing comparisons with several independent codes and cross section sets. For an infinite homogeneous system of ${ }^{239} \mathrm{Pu}$ with $\mathrm{H}_{2} \mathrm{O}$ moderator at a concentration of $3.2 \mathrm{~g} \mathrm{Pu} / \mathrm{lb} \mathrm{H} \mathrm{H}_{2} \mathrm{O}$, the SCAMP calculation resulted in a $k_{\text {eff }}$ of 1.004 . This indicates good agreement between the code and literature where the critical concentration for $\mathrm{Pu}$ in water is reported at $7 \mathrm{~g} / \mathrm{\ell}$, which is equivalent to $3.175 \mathrm{~g} \mathrm{Pu} / \mathrm{b}$ $\mathrm{H}_{2} \mathrm{O}$ (Ref. 8).

The same type of large extensions to the range of applicability are necessary for many of the other materials used in this evaluation where benchmark critical data are entirely unavailable. Calculations incorporating identical geometry, atom densities, moderation, and reflection were performed with SCAMP using Hansen-Roach cross sections, KENO-V.a using 16-group cross sections based on Hansen-Roach data, KENO-V.a using 27-group cross sections based on ENDF/B-IV data, and MCNP using continuous energy ENDF/B-V cross-sections. It should be noted that different versions of the Hansen-Roach library were used for SCAMP and KENO-V.a. Additional SCAMP calculations using 16-group ENDF/B-V cross-section data processed by the COMBINE code were included for some materials. The results are reported in Table 1. The calculations were performed to provide validation for the SCAMP results by comparison.

For many of the materials, good agreement was achieved for the results of all of the codes used. Where slight differences exist, SCAMP is generally conservative and for such cases, SCAMP

aL. M. Montierth, Development and Validation Notes - CSAS4/IBM RISC 6000, NRRT-N-91-020 Rev. 1, May 1992.

L. M. Montierth, Development and Validation Notes - CSAS4/HP 9000 720, NRRT-W-92-005, August 1992. (Intemal documents available for viewing upon request at the Idaho National Engineering Laboratory.) 
Table 1. Code comparisons for initial critical concentrations of ${ }^{239} \mathrm{Pu}$ in waste.

\begin{tabular}{|c|c|c|c|c|c|c|c|}
\hline \multirow{3}{*}{ Case } & \multicolumn{2}{|c|}{ Description } & \multirow{2}{*}{\multicolumn{2}{|c|}{$\frac{k}{\text { SCAMP }}$}} & \multicolumn{3}{|c|}{$k_{-} \pm \sigma$} \\
\hline & \multirow{2}{*}{ Matrix material } & \multirow{2}{*}{$\begin{array}{c}{ }^{230} \mathrm{Pu} \\
\text { concentration } \\
\text { (g Pu/b matrix) }\end{array}$} & & & \multicolumn{2}{|c|}{ KENO-V.a } & \multirow{2}{*}{$\frac{\text { MCNP }}{\begin{array}{c}\text { Continuous energy } \\
\text { ENDF/B-V }\end{array}}$} \\
\hline & & & Hansen-Roach & $\begin{array}{c}\text { 16-group COMBINE } \\
\text { ENDF/B-V }\end{array}$ & Hansen-Roach & $\begin{array}{l}\text { 27-group SCALE4 } \\
\text { ENDF/B-IV }\end{array}$ & \\
\hline 1 & water & 3.2 & 1.004 & $0.994^{*}$ & $1.004 \pm 0.001$ & $0.998 \pm 0.001$ & $0.991 \pm 0.001$ \\
\hline 2 & polyethylene & 4.15 & 1.006 & $0.998^{\circ}$ & $1.005 \pm 0.001$ & $1.000 \pm 0.001$ & $0.996 \pm 0.0005$ \\
\hline 3 & cellulose & 1.8 & 1.006 & & $1.007 \pm 0.001$ & $0.999 \pm 0.001$ & $0.989 \pm 0.0005$ \\
\hline 4 & aluminum metal & 1.25 & 1.043 & & $1.041 \pm 0.001$ & $1.038 \pm 0.002$ & $1.007 \pm 0.001$ \\
\hline 5 & concrete $^{b}$ & 0.75 & 0.998 & & $1.010 \pm 0.001$ & $0.995 \pm 0.001$ & $0.990 \pm 0.001$ \\
\hline 6 & $\mathrm{Al}_{2} \mathrm{O}_{3}$ & $0.37^{\circ}$ & 0.995 & $1.097^{\circ}$ & $0.996 \pm 0.001$ & $1.082 \pm 0.001$ & $1.085 \pm 0.001$ \\
\hline 7 & $\mathrm{SiO}_{2}$ & $0.16^{c}$ & $1.018^{d}$ & $0.913^{n}$ & $0.828 \pm 0.001$ & $0.898 \pm 0.001$ & $0893 \pm 0.001$ \\
\hline 8 & MgO & $020^{\circ}$ & $1.002^{d}$ & & $1.178 \pm 0.001$ & $1.236 \pm 0.001$ & $1.238 \pm 0.001$ \\
\hline 9 & graphite & 0.03 & 1.079 & & $1.079 \pm 0.002$ & $1.097 \pm 0.002$ & $1.084 \pm 0.001$ \\
\hline 10 & graphite & $0.6^{\circ}$ & 1.910 & & $1.91 \pm 0.001$ & $1.847 \pm 0.002$ & $1.872 \pm 0.001$ \\
\hline
\end{tabular}

a Calculated on Silicon-Graphics-40/35 Workstation

b Ordinary concrete as given in the KENO Hansen-Roach cross section library

c These "critical concentration" values are based on the intial SCAMP results using Hansen-Roach cross section data Due to the findings discussed in Section 42 , the actual critical values used for subsequent calculations dffer

d There are errors in the SCAMP Hansen-Roach library for this material If corrected, results similar to the KENO-V a results are obtaned Calculations for this material were made with KENO-V a using CSAS processed 27-energy-group cross section data

e This case is supercritical but is included in these results as a comparison for higher plutonium concentrations in graphite 
results were used to determine critical values. However, $\mathrm{SiO}_{2}, \mathrm{MgO}$, and $\mathrm{Al}_{2} \mathrm{O}_{3}$ cases resulted in pronounced discrepancies in the calculated $k_{\text {eff }}$ values for the various codes apparently because of problems with using the Hansen-Roach cross sections for silicon, magnesium, aluminum, and oxygen in dry systems. Throughout the report, cases containing $\mathrm{SiO}_{2}, \mathrm{MgO}$, or $\mathrm{Al}_{2} \mathrm{O}_{3}$, which were originally evaluated using SCAMP or KENO-V.a with Hansen-Roach cross section data, were recalculated using KENO-V.a with 27-energy-group cross sections through the CSAS code sequence. For all except the aluminum metal case, results from KENO-V.a calculations using the 27-group cross section library agreed reasonably well with MCNP calculations using ENDF/B-V cross section data. The cause of the difference for aluminum metal was not determined; however, critical values for the metal matrix (aluminum) were based on SCAMP results since these were conservative.

While the results indicate reasonably good agreement among the different codes and cross section sets, they also indicate a need for benchmark data for typical waste matrices that have not traditionally been included in criticality safety calculations. 


\subsection{DISCUSSION OF CONTINGENCIES}

A criticality in a large array of waste containers is considered to be incredible. To achieve a critical configuration in such containers, unrealistically high (incredible) ${ }^{239} \mathrm{Pu}$ concentrations in a large number of containers would be required. According to the waste database information, the number of drums with fissile material concentrations at $75 \%$ of calculated critical values for fully infinite systems (with no steel or spacing from drums) is insignificant. A situation where many drums exceed the recorded values would only be reached if large errors existed in the database due to a systematic failure of all of the measurement methods and gross violations of the waste packaging and shipping procedures. If such errors exist and if all (rather than a random number) underestimate the amount of fissile material by $100 \%$, the number of drums that exceed threshold values ( $75 \%$ of calculated critical concentration) is still very small, about $6 \%$ of the total number of waste drums (see Table 14, Section 6.5).

As previously stated, the conditions required for an inadvertent criticality are considered to be incredible, therefore, double contingency analysis is not required. 


\subsection{EVALUATION AND RESULTS}

Section 6.1 below contains a discussion of the simplifications used to limit the number of calculations by determining a small number of materials to represent the various types of waste stored at the RWMC. Actual atom densities used for the calculations are listed in Appendix A. Section 6.2 gives the details of the various models used and the results of the calculations. There are some drums listed in the database which exceed calculated threshold values; these are discussed in Section 6.3. The improbability of a criticality in a single drum is discussed in Section 6.4. Section 6.5 contains an analysis of the impact of possible errors in the database. Typical input listings are given in Appendix $B$.

\subsection{Content Code Groupings}

Waste containers at RWMC are labeled with identifying content codes which were developed over time. " For the present analysis, content codes were grouped into several larger categories depending on the main component of the waste form. This allowed a comparison of the reactivity for various matrices while reducing calculations to a manageable number. Code numbers 800-899 appear in the two references with conflicting descriptions. For purposes of this evaluation those code numbers are handled according to Mound Laboratory waste code descriptions ${ }^{a}$ which correspond to the INEL database. The 800-899 numbers are also used as Rocky Flats pre-certified codes, but are preceded by an RF indicator on those containers.

Table 2 shows the major component list for the nine groups of content codes. Each component represents a commonly occurring constituent in a portion of the waste drums stored at the RWMC. Because water is important with regards to criticality concerns, a water matrix has been evaluated and presented in this report even though there are no drums having content codes currently classified as water. The large number of mixtures actually present in the drums would be arduous to model, but knowledge of the neutron moderating or absorbing behavior of some of the materials, coupled with parametric optimization, allows the actual compositions to be conservatively represented by simpler models. Appendix $\mathrm{C}$ contains an abbreviated summary of the content code descriptions and Appendix

$D$ contains the summary database information.

${ }^{2}$ T. L. Clements, Jr., Content Code Assessments for INEL Contact-Handled Stored Transuranic Wastes, WM-F1-82-021, Idaho National Engineering Laboratory, October 1982.

T. L. Clements, Jr., Program Plan for Certifications of INEL Contact-Handled Stored Transuranic Wastes, WM-PD-88-011-4, Idaho National Engineering Laboratory, July 1991. (Intemal documents available for viewing upon request at the Idaho National Engineering Laboratory.) 
Table 2. Content code grouping for calculations.

\begin{tabular}{|c|c|c|c|c|c|c|c|c|c|}
\hline Group \# & 1 & 2 & 3 & 4 & 5 & 6 & 7 & 8 & 9 \\
\hline $\begin{array}{c}\text { Major } \\
\text { Component }\end{array}$ & $\begin{array}{l}\text { Water } \\
\left(\mathrm{H}_{2} \mathrm{O}\right)\end{array}$ & $\begin{array}{l}\text { Polyethylene } \\
\quad\left(\mathrm{CH}_{2}\right)\end{array}$ & $\begin{array}{l}\text { Graphite } \\
\text { (C) }\end{array}$ & $\begin{array}{l}\text { Glass, Slag } \\
\left(\mathrm{SiO}_{2}, \mathrm{MgO}\right)\end{array}$ & $\begin{array}{l}\text { Cellulose } \\
\left(\mathrm{C}_{6} \mathrm{H}_{10} \mathrm{O}_{5}\right) \\
\end{array}$ & Concrete" & $\begin{array}{c}\text { Metals } \\
\text { (Al) }\end{array}$ & $\begin{array}{c}\text { Salt } \\
(\mathrm{NaCl}, \mathrm{CaCl})\end{array}$ & $\begin{array}{c}\text { Brick } \\
\left(\mathrm{Al}_{2} \mathrm{O}_{3}\right)\end{array}$ \\
\hline $\begin{array}{l}\text { Content Codes } \\
\text { Description of } \\
\text { Content Codes } \\
\text { geven in Appendix } \\
\text { C }\end{array}$ & & $\begin{array}{c}3 \\
112 \\
123 \\
153 \\
202 \\
332 \\
337 \\
339 \\
423 \\
430 \\
431 \\
432 \\
460 \\
463 \\
700 \\
802 \\
804 \\
812\end{array}$ & $\begin{array}{l}115 \\
300 \\
301 \\
303 \\
310 \\
311 \\
312 \\
814\end{array}$ & $\begin{array}{c}7 \\
30 \\
40 \\
69 \\
90 \\
100 \\
102 \\
105 \\
114 \\
118 \\
150 \\
241 \\
368 \\
370 \\
372 \\
390 \\
391 \\
392 \\
393 \\
420 \\
421 \\
422 \\
425 \\
440 \\
441 \\
442 \\
470 \\
483 \\
810 \\
813 \\
834 \\
955 \\
990\end{array}$ & $\begin{array}{l}10 \\
116 \\
119 \\
120 \\
121 \\
153 \\
203 \\
302 \\
328 \\
330 \\
331 \\
334 \\
335 \\
336 \\
338 \\
360 \\
361 \\
375 \\
376 \\
438 \\
464 \\
490 \\
491 \\
801 \\
805 \\
826 \\
827 \\
847 \\
900 \\
970\end{array}$ & $\begin{array}{c}1 \\
2 \\
4 \\
15 \\
95 \\
111 \\
113 \\
122 \\
152 \\
154 \\
157 \\
200 \\
204 \\
290 \\
292 \\
295 \\
299 \\
374 \\
701 \\
702 \\
811 \\
812 \\
836 \\
960 \\
976 \\
978 \\
980 \\
995\end{array}$ & $\begin{array}{c}20 \\
101 \\
117 \\
155 \\
156 \\
201 \\
320 \\
321 \\
333 \\
416 \\
480 \\
481 \\
482 \\
488 \\
803 \\
824 \\
825 \\
950\end{array}$ & $\begin{array}{c}5 \\
124 \\
409 \\
410 \\
411 \\
412 \\
413 \\
414 \\
429 \\
454\end{array}$ & $\begin{array}{l}\mathbf{3 7 1} \\
\mathbf{3 7 3} \\
\mathbf{3 7 7} \\
\mathbf{3 7 8} \\
\mathbf{3 7 9}\end{array}$ \\
\hline
\end{tabular}

a Ordinary concrete as given in the KENO Hansen-Roach cross section library 
Aluminum was chosen to represent metal waste such as ducting, cut-up glove boxes, source housings, and other equipment. Preliminary calculations showed that, for the fully infinite systems evaluated, aluminum is a more reactive matrix material than either copper or stainless steel. Lead is a more reactive matrix material than aluminum, but was not a logical choice to represent the types of material actually present since it occurs in much smaller amounts than the other metals. Only 5 of the 23 metal content code descriptions mention that lead may be present in some drums, and for only one code (321) is it the major component.

After initial calculations indicated which pure matrix materials increased reactivity, the content code groupings were reexamined. If there was more than one major constituent for a content code or if the major constituent could not be determined from the description, every effort was made to group that code with the most reactive component. This means that drums containing some amount of more than one of the pure materials are conservatively enveloped by the models used. Due to this method of categorizing code descriptions, one of the more reactive matrix groups (glass/slag modeled as $\mathrm{SiO}_{2}$ or $\mathrm{MgO}$ ) includes the largest number of content codes. Some error may still result from misinterpretation or lack of sufficient documentation about the actual drum contents; however, the approach used is conservative, especially in combination with other factors considered in the evaluation. 


\subsection{Calculations and Results}

This section gives the details of the various models used and the results of the calculations. Section 6.2.1 contain the primary results of the comparison of the database to the calculations. Sections 6.2.2 through 6.2.5 contain the results of parametric studies and other variations used to verify conservatism.

6.2.1 Fully Infinite Systems and Comparison of Results to the Database

SCAMP (Hansen-Roach) or KENO-V.a (27-group) calculations were performed for fully infinite systems of ${ }^{239} \mathrm{Pu}$, at various concentrations, mixed with several non-fissile matrix materials. Fully infinite systems were represented in the code input by applying mirror reflection to the top and bottom faces of a 100-cm-thick slab (SCAMP) or to all faces of a cube having $100-\mathrm{cm}$ sides (KENO-V.a).

Representative input listings for the calculations are included in Appendix $B$ of this document. Parametric calculations were performed in which the plutonium density, in terms of grams of ${ }^{239} \mathrm{Pu}$ per pound of matrix material, was varied to obtain calculated $k_{\infty}$ values in the range of 0.9 to 1.0 . The results of these calculations are given in Table 3; curves generated from these results for each of the matrix materials can be seen in Figures 1 and 2 . From these data, the critical concentration was determined. A calculation for a salt mixture of $\mathrm{NaCl}$ and $\mathrm{CaCl}_{2}$ was also performed. The results are given in Table 3 but have not been included on the plots because the critical concentration $(7.4 \mathrm{~g} \mathrm{Pu} / \mathrm{lb}$ matrix) was much higher than for the other materials.

Once the critical concentration for a fully infinite system was established, the number of drums with a concentration ( $\mathrm{g} \mathrm{Pu} / \mathrm{b}$ matrix) greater than $75 \%$ of critical was determined from fissile gram content and matrix weight reported in the database. (As can be seen from Figures 1 and 2, calculated $k_{\infty}$ values corresponding to a concentration equal to $75 \%$ of the critical value were well below 0.95 .) $A$ summary of comparative information for all waste matrix materials evaluated is provided in Table 4. These results indicate that, except for graphite, fewer than $9 \%$ of the drums in each group contained a concentration of ${ }^{239} \mathrm{Pu}$ at or above this level for all of the selected waste matrix materials. The worst case was graphite for which over $80 \%$ of the drums exceeded the threshold concentration calculated for the fully infinite graphite systems. The next worse case was the glass group using $\mathrm{MgO}$ as the matrix material, in which 887 or $8.96 \%$ of the drums exceeded $0.09 \mathrm{~g} \mathrm{Pu} / \mathrm{lb}$ matrix (75\% of the critical value for an infinite system of ${ }^{239} \mathrm{Pu}$ in $\mathrm{MgO}$ ). Section 6.3 contains further discussion for the drums which exceed the threshold values and the results of calculations which demonstrate, that under the worst conditions, the currently stored drums could not approach a critical configuration. 
Table 3. Results of SCAMP and KENO-V.a calculations used to determine the calculated critical concentration of ${ }^{239} \mathrm{Pu}$ in various matrix materials.

\begin{tabular}{|c|c|c|c|c|c|c|}
\hline \multicolumn{2}{|c|}{ Matrix group } & \multirow{2}{*}{$\begin{array}{l}{ }^{230} \mathrm{Pu} \\
\text { Concentration } \\
\text { (g Pu/b matrix) }\end{array}$} & \multicolumn{2}{|c|}{$k_{-}$} & \multicolumn{2}{|c|}{ Calculated critical concentration } \\
\hline Number & Material & & SCAMP & KENO-V.ab & g Pu/b matnx & g Pu/l matrx \\
\hline 1 & water & $\begin{array}{l}2.0 \\
2.5 \\
3.0 \\
3.5 \\
4.0\end{array}$ & $\begin{array}{l}0.76790 \\
0.87860 \\
0.97159 \\
1.05079 \\
1.11899\end{array}$ & & 3.17 & 6.99 \\
\hline 2 & polyethylene & $\begin{array}{l}2.5 \\
3.0 \\
3.5 \\
4.0 \\
4.5\end{array}$ & $\begin{array}{l}0.75082 \\
0.84034 \\
0.91840 \\
0.98700 \\
1.04770\end{array}$ & & 4.10 & 8.32 \\
\hline 3 & graphite & $\begin{array}{l}0.020 \\
0.025 \\
0.030 \\
0.050\end{array}$ & $\begin{array}{l}0.87119 \\
0.98535 \\
1.07931 \\
1.33341\end{array}$ & & 0.03 & 0.09 \\
\hline 4 & $\begin{array}{l}\text { glass, slag }\left(\mathrm{SiO}_{2}\right) \\
\text { glass, slag (MgO) }\end{array}$ & $\begin{array}{l}0.10 \\
0.12 \\
0.14 \\
0.15 \\
0.16 \\
0.20 \\
0.25 \\
\\
0.05 \\
0.07 \\
0.10 \\
0.12 \\
0.13 \\
0.15 \\
0.20 \\
0.25 \\
0.30\end{array}$ & & $\begin{array}{l}0.67934 \\
0.76000 \\
0.83545 \\
0.86852 \\
0.89770 \\
1.00844 \\
1.11525 \\
\\
0.58225 \\
0.73056 \\
0.90398 \\
0.99442 \\
1.03267 \\
1.10303 \\
1.23570 \\
1.32796 \\
1.39530\end{array}$ & 0.20 & 1.01 \\
\hline 5 & cellulose & $\begin{array}{l}1.0 \\
1.5 \\
2.0 \\
2.5 \\
3.0\end{array}$ & $\begin{array}{l}0.71291 \\
0.91253 \\
1.06017 \\
1.17690 \\
1.26237\end{array}$ & & 1.78 & 2.51 \\
\hline
\end{tabular}


Table 3. Continued.

\begin{tabular}{|c|c|c|c|c|c|c|}
\hline \multicolumn{2}{|c|}{ Matrix group } & \multirow{2}{*}{$\begin{array}{c}{ }^{250} \mathrm{Pu} \\
\text { Concentration } \\
\text { (g Pu/b matrix) }\end{array}$} & \multicolumn{2}{|c|}{$k_{-}$} & \multicolumn{2}{|c|}{ Calculated critical concentration } \\
\hline Number & Material & & SCAMPa & KENO-V. $a^{b}$ & g Pu/b matrix & g Pu/l matrix \\
\hline 6 & concrete & $\begin{array}{l}0.50 \\
0.60 \\
0.75 \\
0.80 \\
1.00\end{array}$ & $\begin{array}{l}0.80125 \\
0.88937 \\
0.99827 \\
1.02957 \\
1.13558\end{array}$ & & 0.75 & 3.93 \\
\hline 7 & metals (Al) & $\begin{array}{l}0.50 \\
0.75 \\
1.00 \\
1.50 \\
2.00\end{array}$ & $\begin{array}{l}0.72271 \\
0.86322 \\
0.96490 \\
1.10633 \\
1.20393\end{array}$ & & 1.10 & 6.54 \\
\hline 8 & salts & $\begin{array}{l}5.0 \\
5.5 \\
6.1 \\
6.5 \\
7.0 \\
8.0\end{array}$ & $\begin{array}{l}0.77896 \\
0.83157 \\
0.88938 \\
0.92561 \\
0.96889 \\
1.04926\end{array}$ & & 7.4 & 35.14 \\
\hline 9 & brick $\left(\mathrm{Al}_{2} \mathrm{O}_{3}\right)$ & $\begin{array}{l}0.20 \\
0.23 \\
0.25 \\
0.28 \\
0.30 \\
0.33 \\
0.37 \\
0.40\end{array}$ & & $\begin{array}{l}0.80372 \\
0.86994 \\
0.90725 \\
0.96033 \\
0.99067 \\
1.03226 \\
1.08136 \\
1.11474\end{array}$ & 0.31 & 2.68 \\
\hline
\end{tabular}

a SCAMP calculations performed using 16-group Hansen-Roach cross sections

b KENO-V a calculations performed using 27-group cross sections based on ENDF/B-IV data

c Ordinary concrete as given in the KENO Hansen-Roach cross section library 


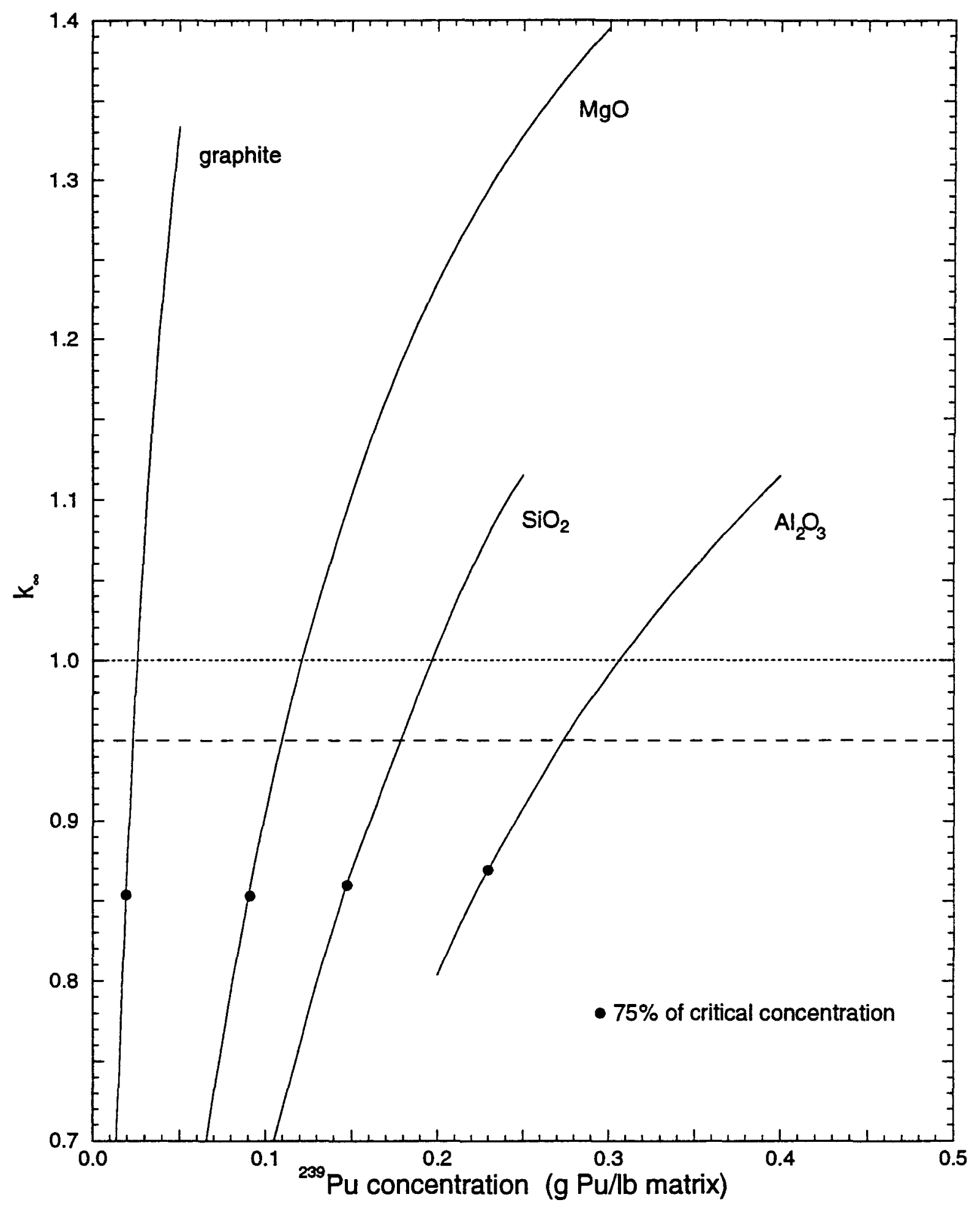

Figure 1. Calculated $\mathrm{k}_{\mathrm{\infty}}$ vs. ${ }^{239} \mathrm{Pu}$ concentration in graphite, $\mathrm{MgO}, \mathrm{SiO}_{2}$, and $\mathrm{Al}_{2} \mathrm{O}_{3}$ 


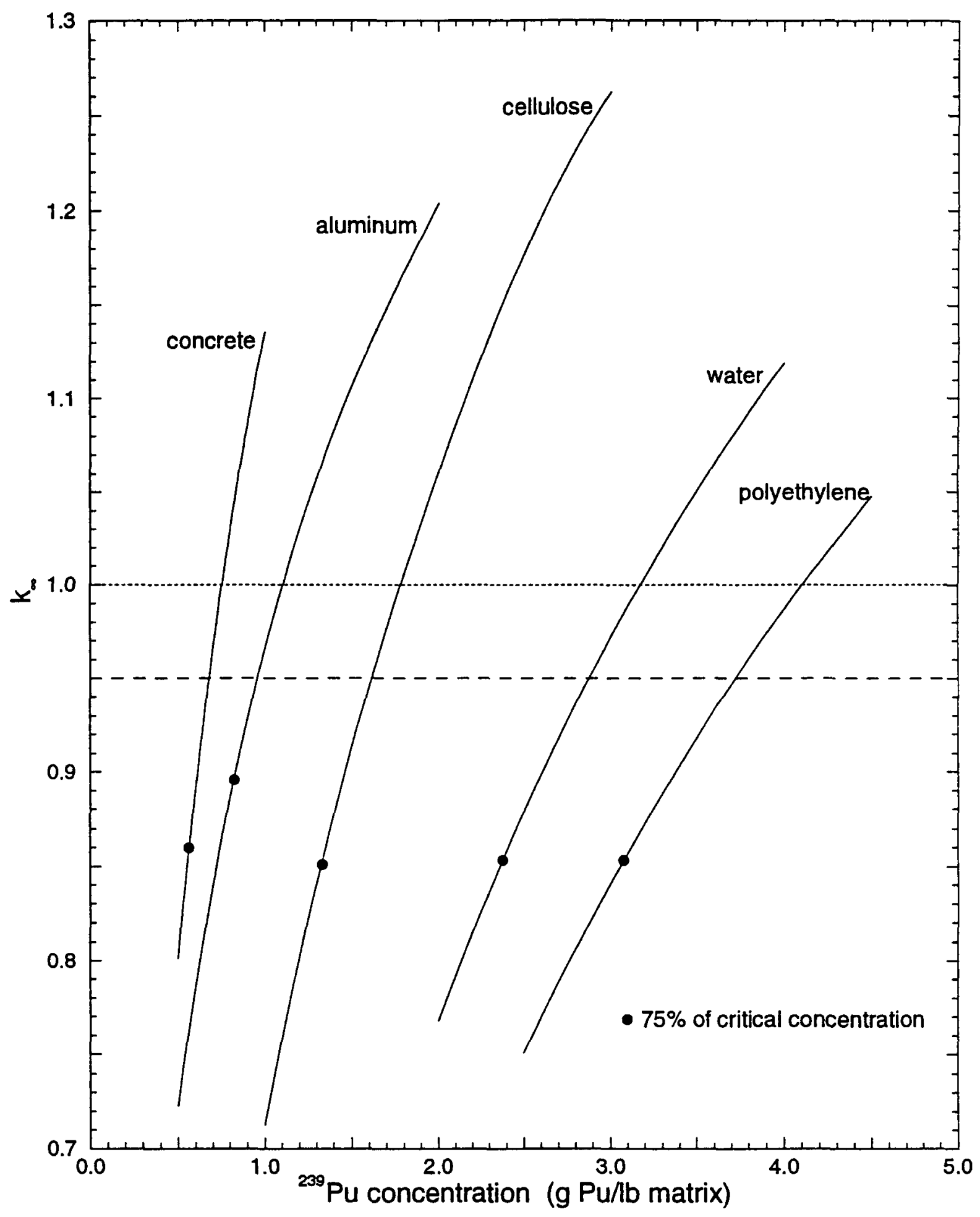

Figure 2. Calculated $\mathrm{k}_{\mathrm{o}}$ vs. ${ }^{239} \mathrm{Pu}$ concentration in $\mathrm{Al}$, concrete, cellulose, water, and polyethylene 
Table 4. Comparison of calculated threshold concentrations with database information.

\begin{tabular}{|c|c|c|c|c|c|c|c|}
\hline \multicolumn{3}{|c|}{ Matrix group } & \multirow{3}{*}{$\begin{array}{c}\text { Threshold } \\
\text { concentration" } \\
\text { (g Pu/b matrix) }\end{array}$} & \multicolumn{4}{|c|}{ Drums } \\
\hline \multirow[t]{2}{*}{ Number } & \multirow[t]{2}{*}{ Material } & \multirow{2}{*}{$\begin{array}{l}\text { Density } \\
\left(\mathrm{g} / \mathrm{cm}^{3}\right)\end{array}$} & & \multirow{2}{*}{$\begin{array}{l}{ }^{230} \mathrm{Pu} \text { mass at } \\
\text { threshold } \\
\text { concentration } \\
\text { (g/drum) }\end{array}$} & \multirow{2}{*}{$\begin{array}{l}\text { Total in } \\
\text { matrix } \\
\text { group } \\
\text { (\#) }\end{array}$} & \multicolumn{2}{|c|}{$\begin{array}{l}\text { Exceeding threshold } \\
\text { concentration }\end{array}$} \\
\hline & & & & & & $\#$ & $\%$ \\
\hline 1 & water & 1.0 & 2.4 & c & c & c & c \\
\hline 2 & polyethylene & 0.92 & 3.1 & 1362.12 & 11376 & 0 & 0.00 \\
\hline 3 & graphite & 1.6 & 0.02 & 14.86 & 2365 & 1904 & 80.51 \\
\hline $4^{c}$ & $\begin{array}{l}\text { glass, slag }\left(\mathrm{SiO}_{2}\right) \\
\text { glass, slag }(\mathrm{MgO})\end{array}$ & $\begin{array}{l}2.32 \\
3.58\end{array}$ & $\begin{array}{l}0.15 \\
0.09\end{array}$ & $\begin{array}{l}166.09 \\
156.94\end{array}$ & $\begin{array}{l}9904^{d} \\
9904^{d}\end{array}$ & $\begin{array}{l}489 \\
887\end{array}$ & $\begin{array}{l}4.94 \\
8.96\end{array}$ \\
\hline 5 & cellulose & 0.64 & 1.3 & 410.49 & 16408 & 308 & 1.88 \\
\hline 6 & concrete ${ }^{\circ}$ & 2.37 & 0.56 & 643.67 & 27526 & 34 & 0.12 \\
\hline 7 & metal (Al) & 2.7 & 0.82 & 1070.19 & 4030 & 59 & 1.46 \\
\hline 8 & salts & 2.16 & 5.53 & 5752.28 & 88 & 1 & 1.14 \\
\hline 9 & brick $\left(\mathrm{Al}_{2} \mathrm{O}_{3}\right)$ & 3.965 & 0.23 & 438.45 & 1031 & 82 & 7.95 \\
\hline
\end{tabular}

a Threshold concentrations correspond to $75 \%$ of the critical concentrations gNen in Table 3

b For information only These mass values should not be construed as mass limits The 200 gram per drum transportation limt still exist and it is assumed that drums do not significantly vilate this limit Under no circumstances should the results of this analysis be applied to drums that contain more than $75 \%$ of the mınımum critıcal mass of plutonum in water (approxımately 380 grams ${ }^{290} \mathrm{Pu}$ ) Special handlıng requirements must be used for drums that exceed 380 grams of ${ }^{200} \mathrm{Pu}$ The handing of highly loaded drums is beyond the scope of this report

c There are no drums in the database classified as water

d Both $\mathrm{SiO}_{2}$ and $\mathrm{MgO}$ were used to evaluate the glass group $\mathrm{SiO}_{2}$ is by far the most predominate of the two The total number of drums in the glass group is 9004. There are not 9904 drums represented as $\mathrm{SiO}_{2}$ and 9904 drums represented as $\mathrm{MgO}$

- Ordinary concrete as given in KENO Hansen-Roach cross section library 
As mentioned in the introduction, boxes and bins of waste are also stored at the RWMC site. Only 37 of the 517 bins $(7.2 \%)$ contain concentrations which are more than the smallest threshold value reported in Table 4 (0.02 g Pu/b matrix calculated for a fully infinite system of ${ }^{239} \mathrm{Pu}$ in graphite). Of these 37 bins, only five have ${ }^{239} \mathrm{Pu}$ concentrations that exceed the threshold value of the next most reactive matrix material, $\mathrm{MgO}(0.09 \mathrm{~g} \mathrm{Pu} / \mathrm{b} \mathrm{MgO})$, and only three exceed the threshold value of the third most reactive matrix material, $\mathrm{SiO}_{2}\left(0.15 \mathrm{~g} \mathrm{Pu}^{\mathrm{lb} \mathrm{SiO}}\right)_{2}$. The database included in Appendix D shows that these three bins contain between 500 and $600 \mathrm{~g}^{299} \mathrm{Pu}$. This amount of fissile material is in excess of the $\mathbf{3 5 0}$ grams per bin limit. However, original manifests were checked by the originator and RWMC and containers in excess of limits were not shipped or accepted. Therefore, these are believed to be errors in the database.

All but nine of the 9943 boxes of radioactive waste $(0.09 \%)$ listed in the database contain concentrations which fall below $75 \%$ of the minimum critical values calculated for fully infinite systems of the various matrix materials. Of these nine boxes, all are categorized as glass or slag. Only one of the nine drums has a concentration that slightly exceeds the minimum critical value of approximately $0.2 \mathrm{~g} \mathrm{Pu} / \mathrm{lb}$ glass. Five boxes, categorized as cellulose, are shown on the database to contain over the 350 gram per box limit, but only two of these boxes exceed $380 \mathrm{~g}^{239} \mathrm{Pu}$. Again, these are believed to be errors in record transcription and not the actual reported gram content.

The average concentration in $\mathrm{g}$ Pu/lb matrix are much smaller for bins and boxes than for drums. The boxes average $0.010 \mathrm{~g} \mathrm{Pu} / \mathrm{b}$ matrix and the bins average $0.007 \mathrm{~g} \mathrm{Pu} / \mathrm{lb}$ matrix compared to $0.018 \mathrm{~g} \mathrm{Pu} / \mathrm{lb}$ matrix in the drums. It may be concluded that the safety of the bins and boxes is adequately demonstrated by the initial calculations for fully infinite systems and by the results in Section 6.3. Waste boxes and bins are not examined further in this report; however, the database information for bins and boxes is included in Appendix $D$. 


\subsubsection{Effects of Discretely Modeled Drums}

Calculations were performed using KENO-V.a to determine the effects of discretely modeled drums. Concrete and cellulose were selected because, as a group, they encompassed the largest number of drums (See Table 4). Graphite was also selected because the threshold concentration for graphite waste is relatively small ( $0.02 \mathrm{~g} \mathrm{Pu} / \mathrm{lb}$ matrix) and because the majority of the drums that are classified as graphite waste exceed the threshold concentration. By applying mirror reflection to all faces of a $57 \times 57 \times 100 \mathrm{~cm}$ cuboid $(57.15 \mathrm{~cm}$ is the inner diameter of a single 55 gallon drum) in a KENO-V.a model, a comparison can be made between the results obtained from Monte Carlo and discrete ordinates methods for fully infinite homogeneous systems. The drums, in a close-packed arrangement, were then modeled using an array of unit cells (Figure 3). Results of calculations using this model, when compared to the homogeneous KENO-V.a results, demonstrate the effects of explicitly modeling the drums in an infinite system. To demonstrate that concrete and water reflectors are no more effective than waste containers, a $42 \times 42 \times 42$ array of explicitly modeled drums, containing either concrete or cellulose matrix, was modeled with a concrete or water reflector on all sides and results are compared to an infinite array of drums (See Cases 3, 4, and 5 of Table 5). Representative input listings for KENO-V.a calculations are included in Appendix B of this document. The results of calculations are reported in Table 5.

A comparison of Cases 2 and 3,7 and 8,12 and 13,15 and 16, and 18 and 19 indicate that the effect of adding steel to represent the drums explicitly depends on the matrix type. The greatest effect of explicitly representing the steel drum structure can be seen in graphite matrix having a low ${ }^{239} \mathrm{Pu}$ concentration (decrease of $30 \%$ ) and the least effect can be seen in the concrete matrix (decrease of $8.5 \%$ ). In all cases, $k_{\infty}$ decreases when the steel drum structure is represented. $A$ comparison of Cases 3,4 and 5, and Cases 8, 9 and 10 indicate that infinite arrays were not substantially more reactive than large finite arrays that are reflected by concrete or water. The results of these two comparisons indicate that the SCAMP and KENO-V.a results for fully infinite, homogenous systems, which are the basis for all threshold values in Table 4, are conservative.

Additional calculations were performed for graphite waste to demonstrate the degree of conservatism in the calculations and to further demonstrate the effects of discretely modeled drums. The results of these calculations are documented in Table 6. The receipt criteria established later in this evaluation are not based in any way on the results in the table nor are these results required to demonstrate the safety of existing containers. However, part of the methodology developed in this section is used in Section 6.3 to demonstrate the safety of existing containers. 


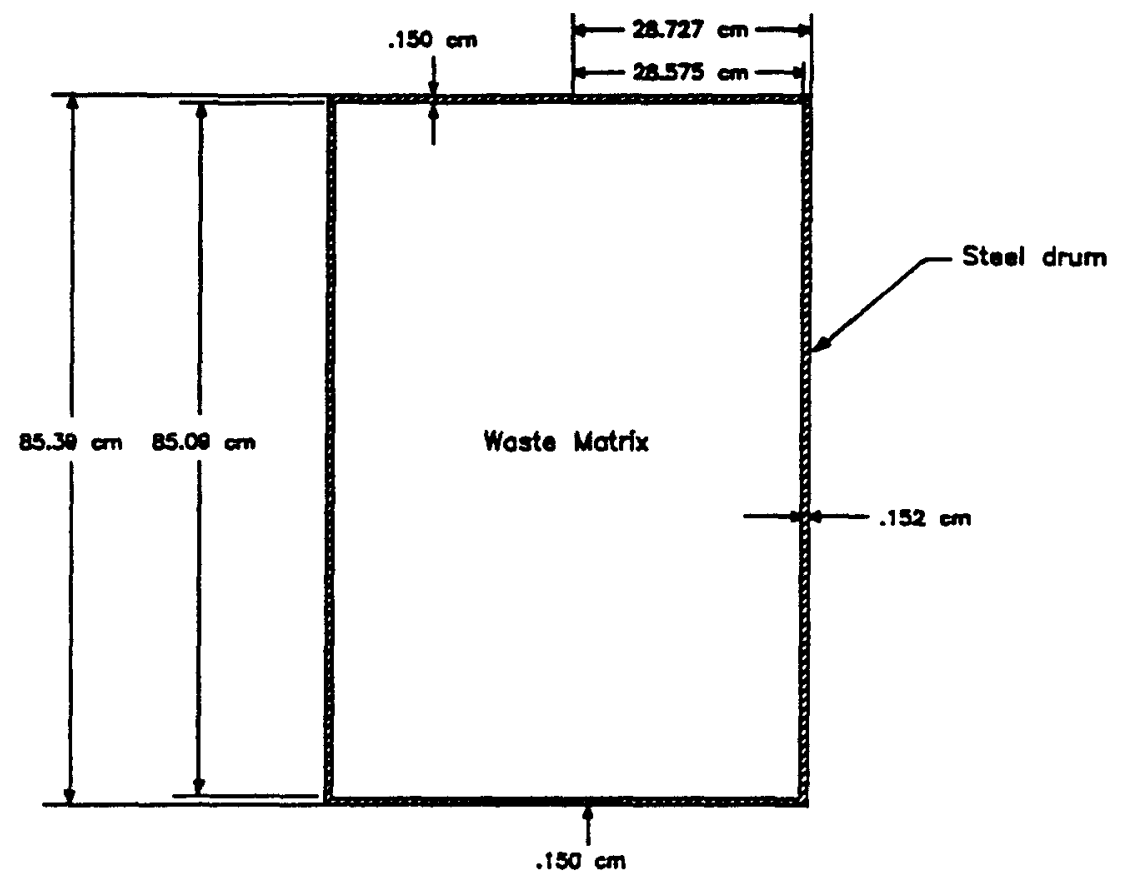

a. Dimensions of 55 gallon storage drum.

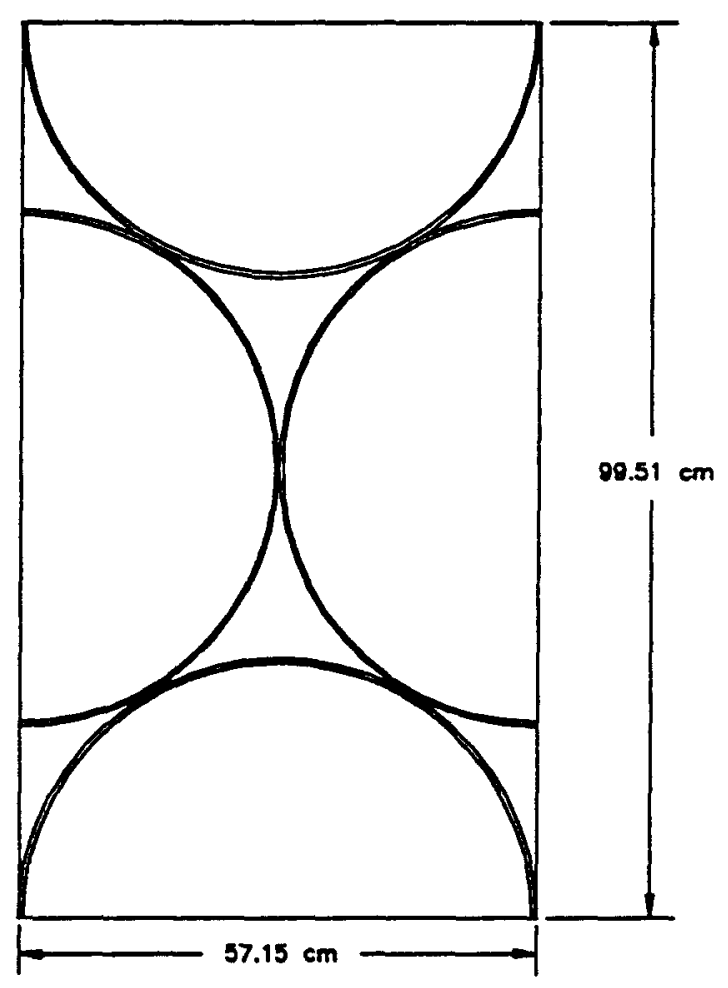

b. Unit cell for KENO model showing four close-pocked 55 gallon drums. cols $-\infty$

Figure 3. Sketch of $\mathbf{5 5}$ gallon waste storage drum showing dimensions and modeled unit cell 
Table 5. Summary of calculations showing the effects of discretely modeled drums and large finite systems.

\begin{tabular}{|c|c|c|c|c|c|c|c|}
\hline \multirow{2}{*}{ Case } & \multicolumn{3}{|c|}{ Model } & \multirow{2}{*}{ Reflector } & \multirow{2}{*}{$\begin{array}{c}\text { SCAMP } \\
k_{\infty}\end{array}$} & \multicolumn{2}{|c|}{ KENO-V.a $a^{b}$} \\
\hline & Description & $\begin{array}{l}\text { Matrix } \\
\text { material }\end{array}$ & $\begin{array}{c}{ }^{230} \mathrm{Pu} \\
\text { concentration } \\
\text { (g Pu/b matrix) }\end{array}$ & & & $k_{\infty} \pm \sigma$ & $k_{\text {off }} \pm \sigma$ \\
\hline 1 & $\begin{array}{l}\text { homogeneous } \\
100 \text {-cm-thick slab }\end{array}$ & concrete ${ }^{c}$ & 0.75 & mirror & 0.998 & & \\
\hline 2 & $\begin{array}{l}57.2 \times 57.2 \times 100 \mathrm{~cm} \\
\text { homogeneous cuboid }\end{array}$ & concrete $^{c}$ & 0.75 & mirror & & $1.010 \pm 0.001$ & \\
\hline 3 & infinite array of drums & concrete $^{c}$ & 0.75 & mirror & & $0.924 \pm 0.001$ & \\
\hline 4 & $\begin{array}{l}42 \times 42 \times 42 \text { array of } \\
\text { steel drums }\end{array}$ & concrete ${ }^{\circ}$ & 0.75 & concrete & & & $0.922 \pm 0.001$ \\
\hline 5 & $\begin{array}{l}42 \times 42 \times 42 \text { array of } \\
\text { steel drums }\end{array}$ & concrete $^{\circ}$ & 0.75 & water & & & $0.922 \pm 0.001$ \\
\hline 6 & $\begin{array}{l}\text { homogeneous } \\
100 \text {-cm-thick slab }\end{array}$ & cellulose & 1.7 & mirror & 0.977 & & \\
\hline 7 & $\begin{array}{l}57.2 \times 57.2 \times 100 \mathrm{~cm} \\
\text { homogeneous cuboid }\end{array}$ & cellulose & 1.7 & mirror & & $0.975 \pm 0.001$ & \\
\hline 8 & infinite array of drums & cellulose & 1.7 & mirror & & $0.850 \pm 0.001$ & \\
\hline 9 & $\begin{array}{l}42 \times 42 \times 42 \text { array of } \\
\text { støel drums }\end{array}$ & cellulose & 1.7 & concrete & & & $0.847 \pm 0.001$ \\
\hline 10 & $\begin{array}{l}42 \times 42 \times 42 \text { array of } \\
\text { ste日l drums }\end{array}$ & cellulose & 1.7 & water & & & $0.847 \pm 0.001$ \\
\hline 11 & $\begin{array}{l}\text { homogeneous } \\
\text { 100-cm-thick slab }\end{array}$ & graphite & 0.5 & mirror & 1.904 & & \\
\hline 12 & $\begin{array}{l}57.2 \times 57.2 \times 100 \mathrm{~cm} \\
\text { homogeneous cuboid }\end{array}$ & graphite & 0.5 & mirror & & $1.906 \pm 0.002$ & \\
\hline 13 & infinite array of drums & graphite & 0.5 & mirror & & $1.328 \pm 0.002$ & \\
\hline 14 & $\begin{array}{l}\text { homogeneous } \\
100 \text {-cm-thick slab }\end{array}$ & graphite & 1.0 & mirror & 1.909 & & \\
\hline 15 & $\begin{array}{l}57.2 \times 57.2 \times 100 \mathrm{~cm} \\
\text { homogeneous cuboid }\end{array}$ & graphite & 1.0 & mirror & & $1.908 \pm 0.002$ & \\
\hline 16 & Infinite array of drums & graphite & 1.0 & mirror & & $1.571 \pm 0.002$ & \\
\hline 17 & $\begin{array}{l}\text { homogeneous } \\
100-\mathrm{cm} \text {-thick slab }\end{array}$ & graphite & 1.5 & mirror & 1.894 & & \\
\hline 18 & $\begin{array}{l}57.2 \times 57.2 \times 100 \mathrm{~cm} \\
\text { homogeneous cuboid }\end{array}$ & graphite & 1.5 & mirror & & $1.892 \pm 0.002$ & \\
\hline 19 & infinite array of drums & graphite & 1.5 & mirror & & $1.662 \pm 0.001$ & \\
\hline
\end{tabular}

\footnotetext{
a SCAMP calculations performed using 16-group Hansen-Poach cross sections

b KENO-V a calculations performed using 16-group KENO cross sections based on Hansen-Poach cross section data

c Ordinary concrete as given in KENO Hansen-Poach cross section library
} 
Table 6. Summary of calculations for drums containing graphite with high concentrations of ${ }^{239} \mathrm{Pu}$ used to determine the thickness of surrounding matrix material necessary to eliminate interaction effects between arrays of drums.

\begin{tabular}{|c|c|c|c|c|}
\hline \multirow{2}{*}{ Case } & \multicolumn{3}{|c|}{ Model of matrix material surrounding array of drums } & \multirow{2}{*}{$\begin{array}{c}k_{\text {off }} \pm \sigma^{2} \\
1.5 g \text { Pu/b of graphite }\end{array}$} \\
\hline & Matrix material & $\begin{array}{c}{ }^{230} \mathrm{Pu} \text { concentration } \\
\text { (g Pu/b matrix) }\end{array}$ & $\begin{array}{l}\text { Thickness } \\
\text { (cm) }\end{array}$ & \\
\hline \multicolumn{5}{|c|}{$\begin{array}{c}\text { Base Model } \\
14 \times 14 \times 14 \text { array of drums (2744 drums) } \\
260 \mathrm{lbs} \text { of graphite per drum based on graphite density of } 1.6 \mathrm{~g} / \mathrm{cm}^{3} \\
\text { array surrounded by thickness of }{ }^{230} \mathrm{Pu} \text { and matrix material on all sides } \\
\text { mirror reflection on all sides }\end{array}$} \\
\hline 1 & $\mathrm{SiO}_{2}$ & 0.15 & 0.001 & $1.347 \pm 0.001$ \\
\hline 2 & $\mathrm{SiO}_{2}$ & 0.15 & 10 & $1.312 \pm 0.001$ \\
\hline 3 & $\mathrm{SiO}_{2}$ & 0.15 & 30 & $1.255 \pm 0.001$ \\
\hline 4 & $\mathrm{SiO}_{2}$ & 0.15 & 60 & $1.216 \pm 0.001$ \\
\hline 5 & $\mathrm{SiO}_{2}$ & 0.15 & 80 & $1.205 \pm 0.001$ \\
\hline 6 & $\mathrm{SiO}_{2}$ & 0.15 & 100 & $1.199 \pm 0.001$ \\
\hline 7 & $\mathrm{SiO}_{2}$ & 0.15 & 110 & $1.194 \pm 0.001$ \\
\hline 8 & $\mathrm{SiO}_{2}$ & 0 & 100 & $1.132 \pm 0.001$ \\
\hline 9 & water & 0 & 100 & $1.034 \pm 0.001$ \\
\hline 10 & $\mathrm{MgO}$ & 0.10 & 100 & $1.193 \pm 0.001$ \\
\hline 11 & Al metal & 0.82 & $2000^{b}$ & $1.180 \pm 0.001$ \\
\hline 12 & $\mathrm{Al}_{2} \mathrm{O}_{3}$ & 0.23 & 100 & $1.187 \pm 0.001$ \\
\hline 13 & cellulose & 1.3 & 100 & $1.113 \pm 0.001$ \\
\hline 14 & polyethylene & 3.1 & 100 & $1.103 \pm 0.001$ \\
\hline 15 & water & 2.4 & 100 & $1.102 \pm 0.001$ \\
\hline
\end{tabular}

a KENO-V a calculations performed using 27-group cross sections based on ENDF/B-N data

b The isolation thickness is much greater for aluminum metal than for compounds containing oxygen and hydrogen 
In a "worst case" scenario, all 2365 drums containing graphite would be stored in a single location. For the calculations documented in Table 6, 2744 drums in a $14 \times 14 \times 14$ array were represented. This size was chosen as a cubic array (cubic by number of drums, not by dimension) with more drums than are actually listed in the inventory data. The volume occupied by the ${ }^{239} \mathrm{Pu} /$ graphite mixture in each drum was based on $260 \mathrm{lbs}$ of the graphite matrix using the theoretical graphite density of $1.6 \mathrm{~g} / \mathrm{cm}^{3}$. As demonstrated in Sections 6.2 .4 and 6.2 .5 , this is a conservative representation for the recorded weight of graphite present in the drums. The weight of $260 \mathrm{lbs}$ was chosen because the information on the database indicated that $98 \%$ of drums containing graphite waste weighed $260 \mathrm{lbs}$ or less. The original intention of this evaluation was to use the maximum recorded weight of drums. Due to changes in the content code groupings, 37 drums heavier than $260 \mathrm{lbs}$ were added to this group after most of the calculations were complete. However, $260 \mathrm{lbs}$ remains the maximum average drum weight when drums are grouped by fissile concentration and the fissile concentration for these drums is low, $0.004 \mathrm{~g}{ }^{239} \mathrm{Pu} / \mathrm{lb}$ graphite. This, along with the fact that the number of drums exceeding $260 \mathrm{lbs}$ is only $2 \%$ of the total number of drums containing graphite on the database supports the decision not to reevaluate all of the graphite cases. Surrounding the array of drums was a cuboid representing the fissile waste contained in the remaining drums (those without graphite). Outside the cuboid surrounding the drums, mirror reflection was applied to all faces to produce an infinite system.

The cuboid surrounding the explicitly modeled drums was parametrically increased in thickness until $k_{\text {eff }}$ was approximately constant. At this point, the interaction between the separate arrays of drums has been eliminated. The additional arrays of drums mentioned here result from the mirror-reflective boundary condition applied to the model. $\mathrm{SiO}_{2}$ matrix was chosen for this parametric study as the material surrounding the array because it is one of the more abundant and more reactive waste matrix materials. An unrealistically high ${ }^{239} \mathrm{Pu}$ concentration of $1.5 \mathrm{~g} \mathrm{Pu} / \mathrm{lb}$ matrix was represented in the graphite matrix in order to maximize interaction effects and isolation thicknesses. The results of this study are shown in Cases 1-7 of Table 6. It can be seen that a 100-cm-thick region surrounding the array of drums $(200 \mathrm{~cm} \mathrm{SiO} 2$ between the arrays) will isolate the modeled array. The $\mathrm{SiO}_{2}$ matrix was replaced by several other matrix materials. Except for aluminum, which has a much larger isolation thickness (2000 cm half-thickness), the 100-cm-thick region, calculated previously, was used in these models. The concentration of ${ }^{239} \mathrm{Pu}$ in each matrix material was held at $75 \%$ of critical value as determined from the previous SCAMP and KENO-V.a calculations. For all of these calculations, the entire array of drums and surrounding cuboid were mirror reflected on all six sides and 5000 neutrons were started in flat distribution. The calculated results for these models are given in Cases 10-15 in Table 6. 
It can be seen from this table that $k_{\text {eff }}$ values for all models are below that calculated for $\mathrm{SiO}_{2}$. $\mathrm{MgO}$ was shown to be more reactive than the other matrix materials, except graphite, in the calculations discussed in Section 6.2.1. However, for these calculations involving drums with graphite, placing $\mathrm{SiO}_{2}$ in the surrounding cuboid was a slightly more reactive configuration. $\mathrm{SiO}_{2}$ has a higher threshold concentration than $\mathrm{MgO}$. Other materials, however, with even higher threshold ${ }^{239} \mathrm{Pu}$ concentrations (water, polyethylene, and cellulose), resulted in significantly lower values of $k_{\text {eff }}$, most likely due to the neutron scattering effects of hydrogen in these materials. Comparing the results of Case 6 to Case 8 and Case 9 to Case 15 in Table 6, in which ${ }^{239} \mathrm{Pu}$ was removed from the surrounding matrix, indicates that the change in $k_{\text {eff }}$ results not only from the choice of matrix, as demonstrated above, but also from the ${ }^{239} \mathrm{Pu}$ concentration in that matrix.

The threshold concentration ( $75 \%$ of the critical concentration) for a fully infinite homogeneous graphite system calculated by SCAMP was $0.02 \mathrm{~g}$ Pulb graphite. A large percentage of drums currently in storage exceed this value. A parametric study was performed to determine the critical concentration of ${ }^{239} \mathrm{Pu}$ in a graphite matrix when 2744 drums are explicitly modeled surrounded by an infinite medium. The results of this study are given in Table 7 and are shown graphically in Figure 4. Table 7 indicates that the calculated $k_{\text {eff }}$ value was approximately 1.0 when the ${ }^{239} \mathrm{Pu}$ concentration was $0.75 \mathrm{~g} / \mathrm{lb}$ graphite with $\mathrm{SiO}_{2}$ as the surrounding infinite medium and $0.80 \mathrm{~g} / \mathrm{lb}$ graphite with $\mathrm{MgO}$ as the surrounding infinite medium. This can also be seen from the results plotted in Figure 4. Using the lower critical concentration of $0.75 \mathrm{~g} \mathrm{Pu} / \mathrm{lb}$ graphite, a threshold concentration (75\% of critical) of $0.56 \mathrm{~g}$ $\mathrm{Pu} / \mathrm{b}$ matrix can be calculated for ${ }^{239} \mathrm{Pu}$ in graphite waste when represented in the discretely modeled drums. This value exceeds the threshold concentration given in Table 4 ( $0.02 \mathrm{~g} \mathrm{Pu} / \mathrm{lb}$ graphite) by a factor of 28.

The calculations documented in Table 6 using a ${ }^{239} \mathrm{Pu}$ concentration in graphite of $1.5 \mathrm{~g} \mathrm{Pu} / \mathrm{lb}$ matrix were repeated using the threshold concentration of $0.56 \mathrm{~g} \mathrm{Pu} / \mathrm{b}$ matrix determined from Table 7. The results of these calculations are given in Table 8 . The results in Table 8 demonstrate that existing drums containing graphite waste will remain in a safely subcritical state when stacked in any configuration. 
Table 7. Summary of calculations for drums containing graphite waste used to determine the critical concentration when discretely modeling drums.

\begin{tabular}{|c|c|c|c|c|}
\hline \multirow{2}{*}{ Case } & \multirow{2}{*}{$\begin{array}{c}{ }^{200} \mathrm{Pu} \text { concentration in } \\
\text { graphite } \\
\text { (g Pu/b graphite) }\end{array}$} & \multicolumn{2}{|c|}{ Matrix material surrounding array of drums } & \multirow{2}{*}{$k_{\text {off }} \pm \sigma^{*}$} \\
\hline & & Material & $\begin{array}{l}{ }^{290} \mathrm{Pu} \text { concentration } \\
\text { (g Pu/b matrix) }\end{array}$ & \\
\hline \multicolumn{5}{|c|}{$\begin{array}{l}\text { Base Model } \\
14 \times 14 \times 14 \text { array of drums (2744 drums) } \\
260 \text { lbs of graphite per drum based on graphite density of } 1.6 \mathrm{~g} / \mathrm{cm}^{3} \\
\text { array surrounded by } 100-\mathrm{cm} \text {-thick region of } 2309 \mathrm{Pu} \text { and matrix material on all sides } \\
\text { mirror reflection on all sides }\end{array}$} \\
\hline 1 & 0.50 & $\mathrm{SiO}_{2}$ & 0.15 & $0.892 \pm 0.001$ \\
\hline 2 & 0.75 & $\mathrm{SiO}_{2}$ & 0.15 & $1.005 \pm 0.001$ \\
\hline 3 & 0.80 & $\mathrm{SiO}_{2}$ & 0.15 & $1.025 \pm 0.001$ \\
\hline 4 & 1.00 & $\mathrm{SiO}_{2}$ & 0.15 & $1.090 \pm 0.001$ \\
\hline 5 & 0.50 & $\mathrm{MgO}$ & 0.10 & $0.853 \pm 0.001$ \\
\hline 6 & 0.75 & $\mathrm{MgO}$ & 0.10 & $0.987 \pm 0.001$ \\
\hline 7 & 0.80 & $\mathrm{MgO}$ & 0.10 & $1.007 \pm 0.001$ \\
\hline 8 & 1.00 & $\mathrm{MgO}$ & 0.10 & $1.079 \pm 0.001$ \\
\hline
\end{tabular}

a KENO-V a calculations performed using 27-group cross sections based on ENDF/B-N data 


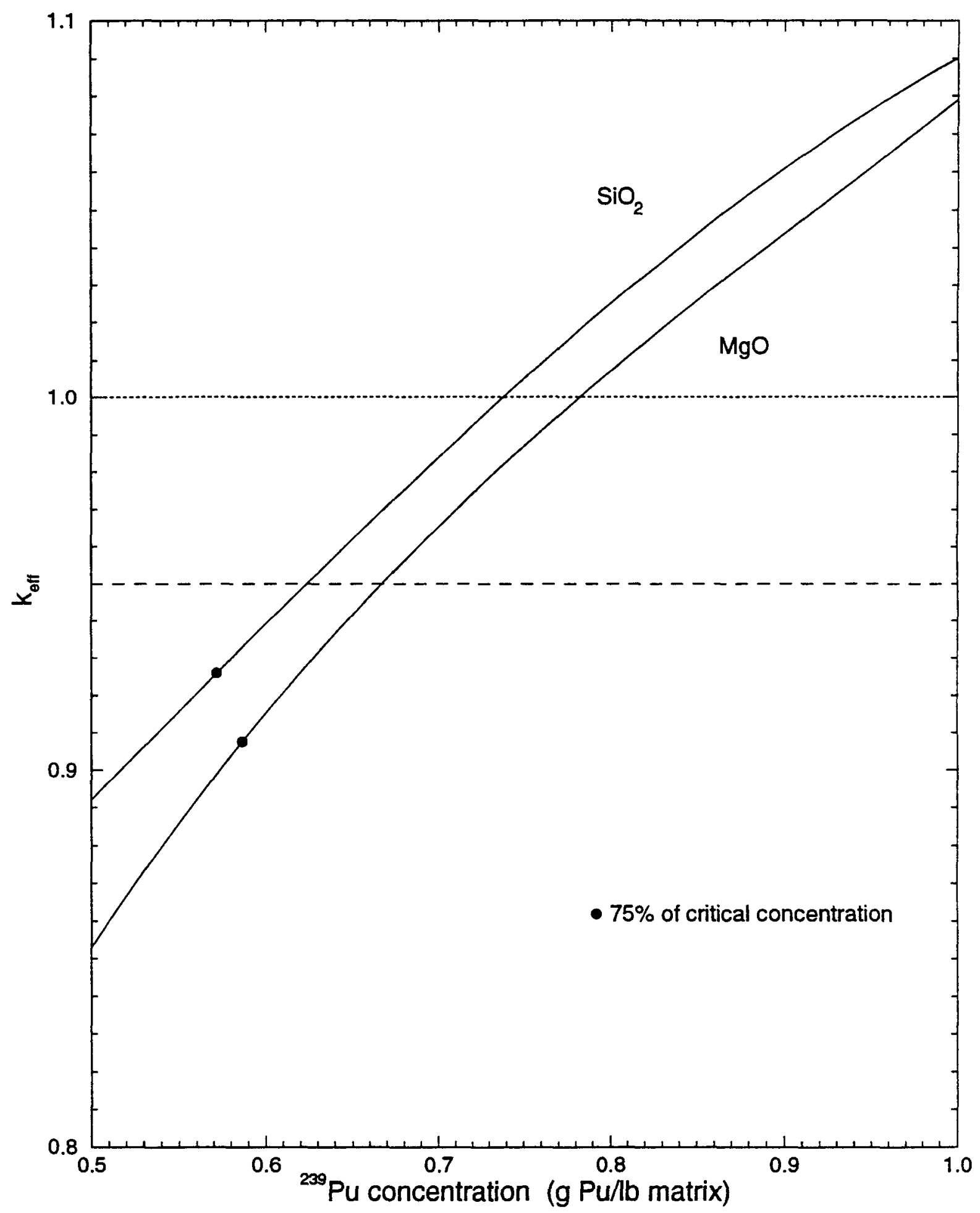

Figure 4. Calculated $k_{\text {off }}$ vs. ${ }^{239} \mathrm{Pu}$ concentration in graphite for discretely modeled drums 
Table 8. Summary of calculations for drums containing graphite with threshold concentrations of ${ }^{239} \mathrm{Pu}$ as determined by explicitly modeling drums.

\begin{tabular}{|c|c|c|c|c|}
\hline \multirow{2}{*}{ Case } & \multicolumn{3}{|c|}{ Model of matrix material surrounding array of drums } & \multirow{2}{*}{$\begin{array}{c}k_{\text {off }} \pm \sigma^{\circ} \\
0.56 g \text { Pu/lb of graphite }\end{array}$} \\
\hline & Matrix material & $\begin{array}{l}{ }^{290} \mathrm{Pu} \text { concentration } \\
\text { (g Pu/b matrix) }\end{array}$ & $\begin{array}{l}\text { Thickness } \\
\text { (cm) }\end{array}$ & \\
\hline \multicolumn{5}{|c|}{$\begin{array}{c}\text { Base Model } \\
14 \times 14 \times 14 \text { array of drums (2744 drums) } \\
260 \mathrm{lbs} \text { of graphite per drum based on graphite density of } 1.6 \mathrm{~g} / \mathrm{cm}^{3} \\
\text { array surrounded by thickness of }{ }^{239} \mathrm{Pu} \text { and matrix material on all sides } \\
\text { mirror reflection on all sides }\end{array}$} \\
\hline 1 & $\mathrm{SiO}_{2}$ & 0.15 & 0.001 & $0.982 \pm 0.001$ \\
\hline 2 & $\mathrm{SiO}_{2}$ & 0.15 & 10 & $0.964 \pm 0.001$ \\
\hline 3 & $\mathrm{SiO}_{2}$ & 0.15 & 30 & $0.947 \pm 0.001$ \\
\hline 4 & $\mathrm{SiO}_{2}$ & 0.15 & 60 & $0.932 \pm 0.001$ \\
\hline 5 & $\mathrm{SiO}_{2}$ & 0.15 & 80 & $0.927 \pm 0.001$ \\
\hline 6 & $\mathrm{SiO}_{2}$ & 0.15 & 100 & $0.921 \pm 0.001$ \\
\hline 7 & $\mathrm{SiO}_{2}$ & 0.15 & 110 & $0.921 \pm 0.001$ \\
\hline 8 & $\mathrm{SiO}_{2}$ & 0 & 100 & $0.800 \pm 0.001$ \\
\hline 9 & water & 0 & 100 & $0.705 \pm 0.001$ \\
\hline 10 & $\mathrm{MgO}$ & 0.10 & 100 & $0.890 \pm 0.001$ \\
\hline 11 & Al metal & 0.82 & $2000^{b}$ & $0.933 \pm 0.001$ \\
\hline 12 & $\mathrm{Al}_{2} \mathrm{O}_{3}$ & 0.23 & 100 & $0.916 \pm 0.001$ \\
\hline 13 & cellutose & 1.3 & 100 & $0.859 \pm 0.001$ \\
\hline 14 & polyethylene & 3.1 & 100 & $0.868 \pm 0.001$ \\
\hline 15 & water & 2.4 & 100 & $0.871 \pm 0.001$ \\
\hline
\end{tabular}

a KENO-V a calculations performed using 27-group cross sections based on ENDF/B-IV data

b The isolation thickness is much greater for aluminum metal than for compounds containing oxygen and hydrogen 


\subsubsection{Effects of Adding Water}

The effect of possible water ingress into the containers in storage was evaluated. Calculations were performed to demonstrate the effect of water addition to only the $\mathrm{SiO}_{2}$ and graphite matrices since these materials have been shown to be two of the most reactive materials. Calculations were performed using infinite homogenous models for water in both $\mathrm{SiO}_{2}$ and graphite matrices. The $\mathrm{SiO}_{2}$ and graphite matrix materials were initially represented at theoretical density. As water was added, these matrix materials were displaced; however, the plutonium concentration conservatively remained at the initial value. Infinite systems were represented by using mirror boundary conditions. Additional calculations were performed for water in the $\mathrm{SiO}_{2}$ matrix where mirror reflection on the top and bottom was replaced with a $30-\mathrm{cm}$-thick concrete reflector. The height of the homogeneous mixture of ${ }^{239} \mathrm{Pu}$ and $\mathrm{SiO}_{2}$ between the concrete reflectors was equivalent to stacking the drums five high.

The results of these calculations are shown in Tables 9 and 10. In all cases, water ingress results in a decrease in $\mathrm{k}$. The results in Table 10 show high $\mathrm{k}_{\infty}$ values resulting from the modeling of unrealistically high ${ }^{239} \mathrm{Pu}$ concentrations in graphite. The negative reactivity effect associated with water addition decreases as ${ }^{239} \mathrm{Pu}$ concentration increases. If a positive reactivity effect, due to water ingress, were to occur, it would be at unrealistically high ${ }^{239} \mathrm{Pu}$ concentrations. Therefore, graphite waste containing realistic ${ }^{239} \mathrm{Pu}$ concentrations will show a larger negative reactivity effect in the event of water ingress and will remain safely subcritical. 
Table 9. Results of KENO-V.a calculations showing the effects of adding water to $\mathrm{SiO}_{2}$ systems.

\begin{tabular}{|c|c|c|c|c|}
\hline \multirow{2}{*}{ Case } & \multicolumn{2}{|c|}{ Volume $\%$} & \multirow{2}{*}{$k_{\text {off }} \pm \sigma^{b, c}$} & \multirow{2}{*}{$k_{\infty} \pm \sigma^{\infty, d}$} \\
\hline & $\mathrm{SiO}_{2}^{*}$ & $\mathrm{H}_{2} \mathrm{O}$ & & \\
\hline 1 & 100 & 0 & $0.819 \pm 0.001$ & $0.869 \pm 0.001$ \\
\hline 2 & 99.5 & 0.5 & $0.799 \pm 0.001$ & $0.841 \pm 0.001$ \\
\hline 3 & 99 & 1 & $0.783 \pm 0.001$ & $0.819 \pm 0.001$ \\
\hline 4 & 98.5 & 1.5 & $0.770 \pm 0.001$ & $0.798 \pm 0.001$ \\
\hline 5 & 98 & 2 & $0.754 \pm 0.001$ & $0.782 \pm 0.001$ \\
\hline 6 & 97.5 & 2.5 & $0.741 \pm 0.001$ & $0.766 \pm 0.001$ \\
\hline 7 & 97 & 3 & $0.727 \pm 0.001$ & $0.751 \pm 0.001$ \\
\hline 8 & 96 & 4 & $0.706 \pm 0.001$ & $0.724 \pm 0.001$ \\
\hline 9 & 95 & 5 & $0.682 \pm 0.001$ & $0.700 \pm 0.001$ \\
\hline 10 & 94 & 6 & $0.663 \pm 0.001$ & $0.677 \pm 0.001$ \\
\hline 11 & 93 & 7 & $0.645 \pm 0.001$ & $0.658 \pm 0.001$ \\
\hline 12 & 92 & 8 & $0.629 \pm 0.001$ & $0.636 \pm 0.001$ \\
\hline 13 & 91 & 9 & $0.611 \pm 0.001$ & $0.622 \pm 0.001$ \\
\hline 14 & 90 & 10 & $0.596 \pm 0.001$ & $0.606 \pm 0.001$ \\
\hline
\end{tabular}

a ${ }^{290} \mathrm{Pu}$ density is held constant at the value established in Case 1 using $015 \mathrm{~g} \mathrm{Pu} / \mathrm{b} \mathrm{S1O}$

b KENO-V a calculations performed using 27 -group cross section based on ENDF/B-IV data

c Homogenous cuboud equivalent to stacking 5 drums high $(42685 \mathrm{~cm})$, 30 -cm-thick concrete reflector on top and bottom and muror reflection on remaining

faces

d Infinite homogenous cubaid with mirror reflection on all faces

Table 10. Results of SCAMP calculations showing the effects of adding water to graphite systems.

\begin{tabular}{|c|c|c|c|c||}
\hline \multirow{2}{*}{ Case } & \multicolumn{2}{|c|}{ Volume \% } & $\begin{array}{c}{ }^{230} \mathrm{Pu} \text { concentration in } \\
\text { graphite } \\
\text { (g Pu/b graphite) }\end{array}$ & $\mathrm{k}$ \\
\cline { 2 - 5 } & graphite & $\mathrm{H}_{2} \mathrm{O}$ & 1.0 & 1.909 \\
\hline 1 & 100 & 0 & 1.0 & 1.661 \\
\hline 3 & 90 & 10 & 1.5 & 1.894 \\
\hline 4 & 100 & 0 & 1.5 & 1.736 \\
\hline 5 & 90 & 10 & 2.0 & 1.878 \\
\hline 6 & 100 & 0 & 2.0 & 1.782 \\
\hline
\end{tabular}

a SCAMP calculations performed using 16-group Hansen-Paach cross sections 100 -cm-thick homogeneous slab with mirror reflection on all sides 


\subsubsection{Effects of Heterogeneity}

The effects of non-homogeneous mixtures of material were studied using SCAMP and KENO-V.a. The calculations were based on the model sketched in Figure 5(a). Layers were formed as shown in the figure and then varied as indicated in Table 11. Variable parameters include region thickness, ${ }^{230} \mathrm{Pu}$ concentration, and mesh intervals (SCAMP calculations only). A complete description of each model variation is included in the table. ${ }^{239} \mathrm{Pu}$ concentrations in each layer were $75 \%$ of critical as determined from the fully infinite homogeneous SCAMP or KENO-V.a results discussed in Section 6.2.1. The calculations were also performed with the ${ }^{239} \mathrm{Pu}$ concentration in graphite layers at $75 \%$ of the critical value as determined from KENO-V.a calculations which included the effects of steel and spacing from explicitly modeled drums as discussed in Section 6.2.2.

The calculated $k_{\infty}$ values are listed in Table 11. The values calculated by SCAMP or KENO-V.a (using 27-group cross sections) for fully infinite homogenous systems of several different matrix materials are also listed for comparison. These results support the use of homogeneous systems. In all cases, the results for layers of different materials produced $k_{\infty}$ values which were no larger than the highest value for the single matrix calculations. Because mixed systems are no more reactive than the single material homogeneous system, the modeling need not include the added complication of layering materials.

As previously stated in Section 6.2.2, special, less conservative, treatment was needed for graphite. Calculated $k_{\infty}$ values are unrealistically high for cases in which $0.56 \mathrm{~g}$ Pulb graphite is included in one or more layers. These values are reduced significantly when the effects of the steel in the drums and actual plutonium concentrations are considered (See Section 6.3). Acceptably low $k_{\infty}$ values are obtained in all cases in which the graphite concentration is fixed at the threshold concentration value ( $0.02 \mathrm{~g} \mathrm{Pu} / \mathrm{lb}$ matrix) established in Section 6.2.1.

Another non-homogeneous configuration to be considered is pieces or strata of fissile material interspersed with the matrix material [See Figure 5(b)]. These calculations were performed with the SCAMP code. The details of layering are described in Table 12. Two models were calculated for each layering scheme. The total thickness of ${ }^{239} \mathrm{Pu}$ in each model was determined by the amount of ${ }^{239} \mathrm{Pu}$ present in a $100-\mathrm{cm}$-thick slab of graphite matrix containing ${ }^{239} \mathrm{Pu}$ concentrations of $1.5 \mathrm{~g} \mathrm{Pu} / \mathrm{lb}$ matrix and $0.03 \mathrm{~g} \mathrm{Pu} / \mathrm{b}$ matrix, respectively. A density of $19.4 \mathrm{~g} / \mathrm{cm}^{3}$ was used for ${ }^{239} \mathrm{Pu}$ metal. The cases in Table 12 show the effects of increasing homogeneity as the ${ }^{239} \mathrm{Pu}$ mass is distributed in one to seven layers. Case 8 is the fully homogeneous calculation. It can be seen from these results that for several 


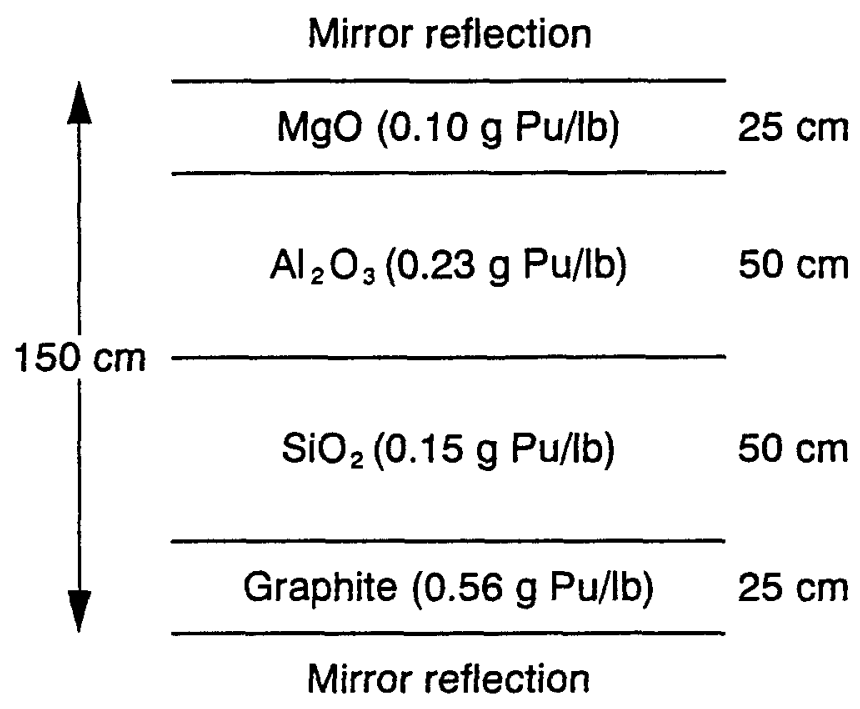

a. Heterogeneous mixture of materials.

(Case 3, Table 11)

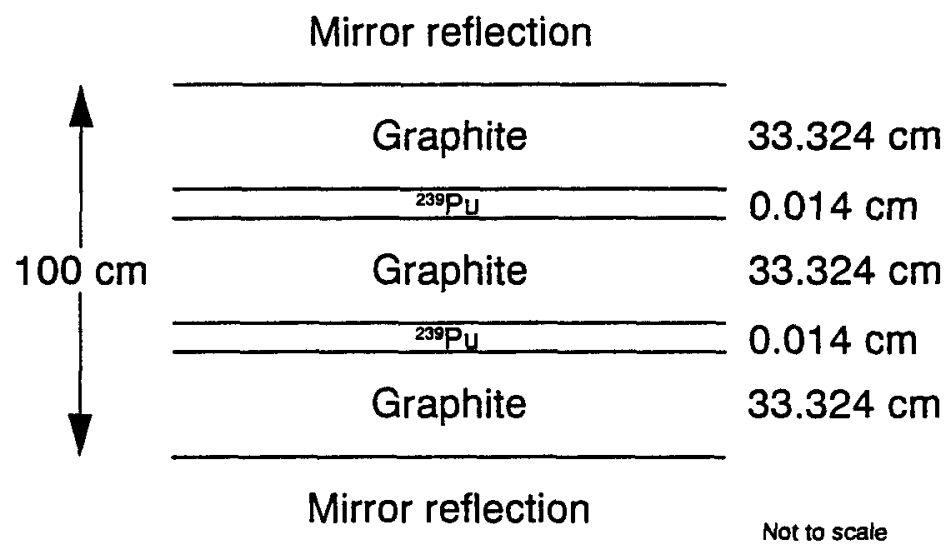

b. Heterogenous layering of $\mathrm{Pu}$. (Case 2, Table 12)

Figure 5. Heterogeneous models used in SCAMP and KENO-V.a 
Table 11. SCAMP or CSAS results showing the effects of layering materials.

\begin{tabular}{|c|c|c|c|c|c|}
\hline Case & $\begin{array}{c}\text { Order and } \\
\text { composition } \\
\text { of layers }\end{array}$ & $\begin{array}{l}\text { Thickness of layers } \\
(\mathrm{cm})\end{array}$ & $\begin{array}{c}{ }^{290} \mathrm{Pu} \\
\text { concentration in } \\
\text { each layer } \\
\text { (g Pu/b matrix) }\end{array}$ & $k^{*}$ & $k_{\infty} \pm \sigma$ \\
\hline 1 & $\begin{array}{c}\mathrm{C} \\
\mathrm{SiO}_{2} \\
\mathrm{Al}_{2} \mathrm{O}_{3} \\
\mathrm{MgO}\end{array}$ & $\begin{array}{c}50 \\
100 \\
100 \\
50\end{array}$ & $\begin{array}{l}0.56^{c} \\
0.15 \\
0.23 \\
0.10\end{array}$ & & $1.521 \pm 0.001$ \\
\hline 2 & $\begin{array}{c}\mathrm{C} \\
\mathrm{SiO}_{2} \\
\mathrm{Al}_{2} \mathrm{O}_{3} \\
\mathrm{MgO}\end{array}$ & $\begin{array}{c}50 \\
100 \\
100 \\
50\end{array}$ & $\begin{array}{l}0.02^{d} \\
0.15 \\
0.23 \\
0.10\end{array}$ & & $0.871 \pm 0.001$ \\
\hline 3 & $\begin{array}{c}\mathrm{C} \\
\mathrm{SiO}_{2} \\
\mathrm{Al}_{2} \mathrm{O}_{3} \\
\mathrm{MgO}\end{array}$ & $\begin{array}{l}25 \\
50 \\
50 \\
25\end{array}$ & $\begin{array}{l}0.56^{c} \\
0.15 \\
0.23 \\
0.10\end{array}$ & & $1.243 \pm 0.001$ \\
\hline 4 & $\begin{array}{c}\mathrm{C} \\
\mathrm{SiO}_{2} \\
\mathrm{Al}_{2} \mathrm{O}_{3} \\
\mathrm{MgO}\end{array}$ & $\begin{array}{l}25 \\
50 \\
50 \\
25\end{array}$ & $\begin{array}{l}0.02^{d} \\
0.15 \\
0.23 \\
0.10\end{array}$ & & $0.862 \pm 0.001$ \\
\hline 5 & $\begin{array}{c}\mathrm{C} \\
\mathrm{H}_{2} \mathrm{O} \\
\mathrm{C} \\
\mathrm{H}_{2} \mathrm{O}\end{array}$ & $\begin{array}{c}50 \\
100 \\
100 \\
50\end{array}$ & $\begin{array}{c}0.56^{c} \\
2.4 \\
0.56^{c} \\
2.4\end{array}$ & 1.307 & \\
\hline 6 & $\begin{array}{l}\mathrm{C} \\
\mathrm{H}_{2} \mathrm{O} \\
\mathrm{C} \\
\mathrm{H}_{2} \mathrm{O}\end{array}$ & $\begin{array}{c}50 \\
100 \\
100 \\
50\end{array}$ & $\begin{array}{c}0.02^{d} \\
2.4 \\
0.02^{d} \\
2.4\end{array}$ & 0.858 & \\
\hline 7 & $\begin{array}{l}\text { poly } \\
\mathrm{H}_{2} \mathrm{O} \\
\text { poly } \\
\mathrm{H}_{2} \mathrm{O}\end{array}$ & $\begin{array}{c}50 \\
100 \\
100 \\
50\end{array}$ & $\begin{array}{l}3.1 \\
2.4 \\
3.1 \\
2.4\end{array}$ & 0.857 & \\
\hline 8 & graphite & full infinite homogeneous system & $0.56^{c}$ & 1.908 & \\
\hline 9 & graphite & full infinite homogeneous system & $0.02^{d}$ & 0.871 & \\
\hline 10 & water & full infinite homogeneous system & 2.4 & 0.858 & \\
\hline 11 & poly & full infinite homogeneous system & 3.1 & 0.857 & \\
\hline 12 & $\mathrm{SiO}_{2}$ & full infinite homogeneous system & 0.15 & & $0.869 \pm 0.001$ \\
\hline 13 & MgO & full infinite homogeneous system & 0.10 & & $0.904 \pm 0.001$ \\
\hline 14 & $\mathrm{Al}_{2} \mathrm{O}_{3}$ & full infinite homogeneous system & 0.23 & & $0.870 \pm 0.001$ \\
\hline
\end{tabular}

a SCAMP calculations performed using 16-group Hansen-Roach cross section data

b KENO-V a calculations using 27-group cross sections based on ENDF/B-IV data

c $75 \%$ of critical concentration from KENO-V a model with partially filled steel drums (Table 7, Section 622 )

d 75\% of critical concentration from infinite homogeneous SCAMP model (Table 4, Section 621 ) 
Table 12. Results of SCAMP calculations showing the effects of non-homogeneous distribution of ${ }^{239} \mathrm{Pu}$ in graphite.

\begin{tabular}{|c|c|c|c|c|c|c|c|c|}
\hline \multirow[t]{3}{*}{ Case } & \multirow{2}{*}{\multicolumn{2}{|c|}{ Number of layers" }} & \multicolumn{4}{|c|}{$\begin{array}{l}\text { Thickness of layers } \\
\text { (cm) }\end{array}$} & \multirow{2}{*}{\multicolumn{2}{|c|}{$k_{m}^{0}$}} \\
\hline & & & \multicolumn{2}{|c|}{$1.5 \mathrm{~g}{ }^{239} \mathrm{Pu} / \mathrm{b}$ graphite } & \multicolumn{2}{|c|}{$0.03 \mathrm{~g}^{239} \mathrm{Pu} / \mathrm{b}$ graphite } & & \\
\hline & graphite & ${ }^{230} \mathrm{Pu}$ & graphite & ${ }^{239} \mathrm{Pu}$ & graphite & ${ }^{290} \mathrm{Pu}$ & $1.5 \mathrm{~g}{ }^{239} \mathrm{Pu} / \mathrm{b}$ graphite & $0.03 \mathrm{~g}^{239} \mathrm{Pu} / \mathrm{b}$ graphite \\
\hline 1 & 2 & 1 & 49.9864 & 0.0272 & 49.999727 & 0.000546 & 1.700 & 0.995 \\
\hline 2 & 3 & 2 & 33.3242 & 0.0136 & 33.333152 & 0.000273 & 1.848 & 1.042 \\
\hline 3 & 4 & 3 & 24.9932 & 0.0091 & 24.999864 & 0.000182 & 1.891 & 1.058 \\
\hline 4 & 5 & 4 & 19.9945 & 0.0068 & 19.999891 & 0.000136 & 1.901 & 1.064 \\
\hline 5 & 6 & 5 & 16.6621 & 0.0055 & 16.666576 & 0.000109 & 1.906 & 1.069 \\
\hline 6 & 7 & 6 & 14.2818 & 0.0045 & 14.285636 & 0.000091 & 1.907 & 1.072 \\
\hline 7 & 8 & 7 & 12.4966 & 0.0039 & 12.499932 & 0.000078 & 1.906 & 1.074 \\
\hline 8 & \multicolumn{2}{|c|}{$1^{\mathrm{c}}$} & \multicolumn{2}{|c|}{$100^{d}$} & \multicolumn{2}{|c|}{$100^{d}$} & 1.894 & 1.079 \\
\hline 9 & \multicolumn{2}{|c|}{$2^{\mathrm{c}}$} & \multicolumn{2}{|c|}{$f$} & \multicolumn{2}{|c|}{$50^{\circ}$} & $f$ & 1.083 \\
\hline
\end{tabular}

a Graphite and ${ }^{239} \mathrm{Pu}$ alternate in model as shown in Figure 5 (b)

b SCAMP calculations performed using 16-group Hansen-Poach cross sections

c Homogeneous mixture of ${ }^{239} \mathrm{Pu}$ and graphite matrx

d Fully infinite homogeneous system

e ${ }^{239} \mathrm{Pu}$ concentration varies between top (0 $02 \mathrm{~g}$ Pulb matrix) and bottom (0 $04 \mathrm{~g}$ Pull matrix) layers

I Not calculated 
layers of metal, the $k_{\text {of }}$ value shows a slight increase (less than $1 \%$ ) over the fully infinite homogeneous system at $1.5 \mathrm{~g} \mathrm{Pu} / \mathrm{lb}$ matrix. These results are reported to demonstrate that homogeneity is an adequately conservative configuration; no major increases in $k_{\text {eff }}$ values or deviations from expected results are observed when the ${ }^{239} \mathrm{Pu}$ is concentrated in layers. 


\subsubsection{Effects of Density and Distribution of Material}

Initial calculations with graphite/Pu mixtures in drums showed that, as expected, drums full of the graphite mixture were more reactive than partially filled drums because filled drums contained a larger mass of fissile material. The weight of a drum completely full of graphite is $770 \mathrm{lbs}$ using the theoretical density of graphite $\left(1.6 \mathrm{~g} / \mathrm{cm}^{3}\right)$. The intention of this evaluation was to use the maximum recorded weight of drums in the distribution. Originally, this weight was $260 \mathrm{lbs}$. Due to changes in the content code groupings, 37 drums with weights greater than $260 \mathrm{lbs}$ were added to this group after most of the calculations were complete. This number represents $2 \%$ of the drums containing graphite that are listed on the database. This, along with the fact that $260 \mathrm{lbs}$ is the maximum average weight when drums are grouped by fissile concentration, support the conclusion that $260 \mathrm{lbs}$ conservatively represents the total graphite and fissile content in the model.

In order to study the effects of density and distribution of the material in the drums, the volume that would be occupied by $260 \mathrm{lbs}$ of graphite was calculated using the theoretical density $\left(1.6 \mathrm{~g} / \mathrm{cm}^{3}\right)$. Maintaining a total weight of $260 \mathrm{lbs}$, the height of the graphite filled region inside the drums was parametrically increased, a new graphite density calculated, and new atom densities determined based on the calculated graphite density and ${ }^{239} \mathrm{Pu}$ concentration of $1.5 \mathrm{~g} \mathrm{Pu} / \mathrm{lb}$ matrix. The results of these calculations are summarized in Table 13. Each decrease in graphite density resulted in a reduced $k_{\text {et }}$ value. This demonstrates that the use of theoretical densities for these calculations is conservative.

Values for $\mathrm{k}_{\text {eff }}$ reported in this section are much higher than would normally be considered. This is because high (relative to critical) ${ }^{239} \mathrm{Pu}$ concentrations and infinite arrays of drums were used. The high fissile loading results in more interaction between drums. This facilitates observing the effects of material distribution. 
Table 13. Summary of KENO-V.a results showing the effects of graphite density and distribution.

\begin{tabular}{|c|c|c|c|c|c|}
\hline Case & $\begin{array}{l}\text { Graphite per } \\
\text { drum } \\
\text { (lbs) }\end{array}$ & $\begin{array}{l}\text { Height of } \\
\text { graphite region } \\
\text { (cm) }\end{array}$ & $\begin{array}{l}\text { Graphite density } \\
\qquad\left(\mathrm{g} / \mathrm{cm}^{3}\right)\end{array}$ & $\begin{array}{c}\text { Volume of } \\
\text { graphite region } \\
\left(\mathrm{cm}^{3}\right)\end{array}$ & $k_{\infty} \pm \sigma^{2}$ \\
\hline \multicolumn{6}{|c|}{$\begin{array}{l}\text { Base Model } \\
\text { infinite array of drums } \\
\text { drums have a modeled inside dimensions of } 28.575 \mathrm{~cm} \text { radius and } 85.09 \mathrm{~cm} \text { height } \\
\text { graphite per drum based on graphite density of } 1.6 \mathrm{~g} / \mathrm{cm}^{3} \\
{ }^{230} \mathrm{Pu} \text { concentration of } 1.5 \mathrm{~g} \text { Pu/b graphite } \\
\text { mirror reflection on all sides }\end{array}$} \\
\hline 1 & 770 & 85.09 & 1.60 & $2.18 \times 10^{5}$ & $1.662 \pm 0.001$ \\
\hline 2 & 260 & 28.81 & 1.60 & $7.39 \times 10^{4}$ & $1.402 \pm 0.001$ \\
\hline 3 & 260 & 38.81 & 1.18 & $9.96 \times 10^{4}$ & $1.382 \pm 0.001$ \\
\hline 4 & 260 & 48.81 & 0.941 & $1.25 \times 10^{5}$ & $1.370 \pm 0.001$ \\
\hline 5 & 260 & 58.81 & 0.782 & $1.51 \times 10^{5}$ & $1.359 \pm 0.001$ \\
\hline 6 & 260 & 68.81 & 0.668 & $1.76 \times 10^{5}$ & $1.348 \pm 0.001$ \\
\hline 7 & 260 & 85.09 & 0.540 & $2.18 \times 10^{5}$ & $1.334 \pm 0.001$ \\
\hline
\end{tabular}

a KENO-V a calculations performed using 16-group Hansen-Foach cross sections 


\subsection{Drums with ${ }^{239} \mathrm{Pu}$ Concentrations in Excess of Threshold Values}

Significant amounts of fissile material are sometimes contained in drums with relatively low overall weights. For certain waste matrix materials, the contents of a portion of those existing drums actually exceeds the calculated critical concentration (i.e., the calculated critical concentration for a fully infinite homogeneous system). Additional calculations were performed for those matrix groups to demonstrate that all existing drums, including those that exceed threshold values, will remain safely subcritical in any possible configuration including compaction due to drum damage. The following methodology was used:

1. The drums with contents that exceed $37.5 \%$ of the critical plutonium concentration were identified in the database. A value of $37.5 \%$ was selected to ensure that all drums that exceed the calculated threshold values reported in Table 4 were included in the study even if errors in the plutonium concentration values reported in the database were as large as a factor of two.

2. Of those drums identified in Item 1, the drum with the maximum average weight for each matrix material was identified. This weight and the theoretical density of the matrix material were used to establish the maximum volume that would be occupied by compacted waste. (Use of the theoretical density was shown to be conservative in Section 6.2.5.) Except in one case which will be discussed later, each of the drums with excessively high plutonium concentrations was represented in a cubical configuration using the maximum volume. The total volume of steel in a drum (-3106 $\mathrm{cm}^{3}$ ) was then uniformly distributed around the cubical waste volume. By representing the drums in this manner, all external and internal void space that is characteristic of a drum array has been removed. Credit is taken for the absorption properties of steel in a conservative fashion. The steel in a drum array is always more effective when uniformly distributed throughout the waste. By representing the steel in the manner described, it is less effective than if the drums were undamaged since realistic damage to steel drums tends to disperse the steel. The thickness of the steel in the cubical drums is actually thicker than in an undamaged drum making it even less effective.

3. Of those drums identified in ltem 1 , the drum with highest ${ }^{239} \mathrm{Pu}$ concentration was identified. This concentration was represented in all drums. In some instances, this method resulted in unacceptably high $k_{\text {eff }}$ values. In these instances, the actual number 
of drums with the higher plutonium concentration were represented and the next highest plutonium concentration was used for the remaining drums. This process was repeated until the calculated $k_{\text {eff }}$ value was reduced to an acceptable level. By following this process, the degree of conservatism is systematically reduced, but in all cases the final representation still includes numerous conservatisms.

4. The drums were arranged within the array so the more highly concentrated waste was positioned near the center of the array. The overall array of drums was forced to be cubic by adding drums of waste material that contain the threshold concentration ( $75 \%$ of the critical concentration) of ${ }^{239} \mathrm{Pu}$ in the $\mathrm{SiO}_{2}$ matrix as reported in Table 4. The actual configurations evaluated may be determined from the input listings given in Appendix $B$ and from the information provided in Appendix $E$.

5. A 100-cm thickness of fissile waste (isolation thickness for $\mathrm{SiO}_{2}$; See Table 6), represented by the threshold concentration of ${ }^{239} \mathrm{Pu}$ in the $\mathrm{SiO}_{2}$ matrix, was represented around the array of drums. Only the fissile and matrix materials were used; the structural material of the drums was not included. Mirror reflective boundary conditions were applied to all faces of the cubic array making the entire system infinite.

The results of these calculations are given in Table 14. Calculations for polyethylene and salts were not performed because none of these drums, or an insignificant number of these drums, exceeded $37.5 \%$ of the critical plutonium concentration. When actual plutonium concentration and number of drums at that concentration is considered, the results in Table 14 indicate that all 55 gallon drums stored at the RWMC will remain safely subcritical in any configuration, even if the drums were to deteriorate significantly. Except for the case in which the waste material is represented as cellulose, all calculated $k_{\text {eff }}$ values are well below 0.95 . Due to very high concentrations $(6.72$ and $5.51 \mathrm{~g} \mathrm{Pu} / \mathrm{lb}$ matrix) in two drums containing cellulose waste, the calculated $k_{\text {eff }}$ value slightly exceeds 0.95 . Both of these drums contain very little waste material. When the actual waste volumes of these two drums are considered, the total contents can be conservatively combined into a single drum. The resulting $k_{\text {eHt }}$ value decreases from 0.954 to 0.864 .

Case 4(c) of Table 14 is included to demonstrate, as was done previously in Section 6.2.5 with graphite, that the use of theoretical densities is conservative. Cases $4(\mathrm{~b})$ and $4(\mathrm{c})$ are for drums 
Table 14. Results of KENO-V.a calculations for maximum concentrations.

\begin{tabular}{|c|c|c|c|c|c|c|c|}
\hline \multirow{2}{*}{ Case } & \multicolumn{2}{|c|}{ Matrix group } & \multirow{2}{*}{$\begin{array}{l}{ }^{230} \mathrm{Pu} \\
\text { concentration } \\
37.5 \% \text { of the } \\
\text { critical } \\
\text { concentration } \\
\text { (g Pu/b matrix) }\end{array}$} & \multicolumn{3}{|c|}{$\begin{array}{l}\text { Drums exceeding } 37.5 \% \text { of the critical } \\
\text { concentration }\end{array}$} & \multirow{2}{*}{$k_{\text {off }} \pm \sigma^{c}$} \\
\hline & Number & Material & & Number & $\begin{array}{l}\text { Maximum } \\
\text { weight } \\
\text { (lb) }\end{array}$ & $\begin{array}{l}\underset{230}{\text { Maximum }} \\
\text { concentration } \\
\text { (g Pu/b matrix) }\end{array}$ & \\
\hline 1 & 1 & water & 1.2 & 0 & & & \\
\hline 2 & 2 & polyethylene & 1.55 & 1 & 41.79 & 2.37 & d \\
\hline 3 & 3 & graphite & 0.01 & 2158 & 203.33 & $1.27-0.10^{\circ}$ & $0.793 \pm 0.0004$ \\
\hline 4 & $\begin{array}{l}4(a) \\
4(b) \\
4(c)\end{array}$ & $\begin{array}{l}\text { glass, slag }\left(\mathrm{SiO}_{2}\right) \\
\text { glass, slag }(\mathrm{MgO})\end{array}$ & $\begin{array}{l}0.075 \\
0.045\end{array}$ & $\begin{array}{l}1015 \\
1202\end{array}$ & $\begin{array}{l}167.63 \\
167.63\end{array}$ & $\begin{array}{l}2.03-0.15^{f} \\
2.03-0.10^{\circ}\end{array}$ & $\begin{array}{l}0.801 \pm 0.0005 \\
0.813 \pm 0.0006 \\
0.800 \pm 0.0004^{n}\end{array}$ \\
\hline 5 & $\begin{array}{l}5(a) \\
5(b)\end{array}$ & cellulose & 0.65 & 484 & 101.05 & $6.72-1.39^{\prime}$ & $\begin{array}{l}0.954 \pm 0.0008 \\
0.864 \pm 0.0006^{4}\end{array}$ \\
\hline 6 & 6 & concrete $^{k}$ & 0.28 & 138 & 202.34 & 1.13 & $0.854 \pm 0.0004$ \\
\hline 7 & 7 & metal (Al) & 0.41 & 209 & 128.83 & 3.44 & $0.872 \pm 0.0004$ \\
\hline 8 & 8 & salts & 2.765 & 10 & 57.32 & 6.09 & d \\
\hline 9 & 9 & brick $\left(\mathrm{Al}_{2} \mathrm{O}_{3}\right)$ & 0.115 & 136 & 185.33 & 0.95 & $0.832 \pm 0.0004$ \\
\hline
\end{tabular}

a Values in this column are $375 \%$ of the crical concentration for a fully infinite system as reported in Table 4

b The equivalent volume of a single drum is based on the maximum average weight of those drums with a concentration greater than $375 \%$ of the critical concentration and on the matrix density listed in Table 4

c KENO-V a calculations performed using 27-group cross sections based on ENDF/B-IV data

d Not calculated

- There were 10 concentration levels modeled for graphte See Section 63

f There were 7 concentration levels modeled for $\mathrm{SiO}_{2}$ See Section 63

g There were 8 concentration levels modeled for $\mathrm{MgO}$ See Section 63

h Base model has been changed to show that using theoretical densities for all calculations is conservative, volume of drum has been doubled and atom densities reduced by a factor of 2

1 There were 6 concentration levels modeled for cellulose See Section 63

1 Two drums have very high concentrations with relatively low weights The calculated $k_{\text {on }}$ value drops from 0954 to 0864 when actual weights of the two most highly concentrated drums are used.

$k$ Ordinary concrete as given in the KENO Hansen-Poach cross section library 
containing waste characterized as MgO. Theoretical density material was used in Case 4(b). In Case 4(c), the volume of the drums was doubled and the atom densities were reduced by a factor of 2. The total mass and ${ }^{239} \mathrm{Pu}$ concentration ( $\mathrm{g}$ Pu/b matrix) remained constant. Calculated $\mathrm{k}_{\text {eff }}$ values of 0.813 and 0.800 resulted for Cases $4(b)$ and $4(c)$, respectively. The closeness of the results of these calculations do not conclusively demonstrate the conservatism of using theoretical densities to model the matrix materials. They do, however, add evidence to the claim that it is not 'less conservative' to model in this manner.

In conclusion, the waste currently stored at RWMC will remain safely subcritical under all normal and credible abnormal conditions. First, because only a small percentage of drums contain excess concentrations, it is incredible that a significant number could be accumulated in one location. Second, even if they are, the containers will still remain safely subcritical. 


\subsection{Single Heavily Loaded Drums}

Placing a sufficiently large mass of fissile material in a single container could result in a criticality accident; however such an event is considered incredible for the following reasons.

1. The mass of plutonium required for a criticality to occur under ideal geometric configurations must exceed $5 \mathrm{~kg}$ of metal, $10 \mathrm{~kg}$ of oxide, or $500 \mathrm{~g}$ of optimally moderated solution (Ref 9). For metal and oxides, it is incredible that mass limit violations of these magnitudes could ever occur and go undetected. Except for special processes, quantities of these magnitudes are never handled at one time. In addition, material accountability requirements are far too rigorous to allow such quantities of plutonium to be inadvertently discarded and such quantities would easily be detected by assay prior to shipment or upon receipt at the INEL.

2. Inadvertently placing $500 \mathrm{~g}$ of solution into a container is more likely. However, an optimal configuration is required for such small quantities of plutonium to result in a criticality. For realistic plutonium concentrations in solution, the minimum critical volume necessary to contain 500 to $1000 \mathrm{~g}$ quantities of fissile material exceeds 7 liters; additional hydrogenous material is also required to provide adequate reflection. Plutonium solutions of this type are processed in containers that do not exceed 1 liter. Damage to a container holding plutonium solution would result in the formation of an even less reactive geometric configuration. Material accountability requirements and assay prior to shipment decrease the possibility that a mass limit violation of this magnitude could occur. A critical configuration requires the combination of a large mass limit violation, optimum geometry, and optimal reflective conditions. This combination in a single container is incredible. 
There are three areas of concern regarding the margins of error in the Rocky Flats (RF) database: (1) The fissile gram concentration of the large stacks of drums at the RWMC versus the calculated threshold concentrations for an infinite array, (2) The number of drums and their concentrations that exceed the threshold concentrations, and (3) The fissile content for single heavily loaded drums. While precise margins of error have not been determined for the Rocky Flats database (and cannot be determined without opening drums), a comparison of the Rocky Flats data with the INEL assay data clearly show that the margins of error are small compared to the margin of safety. A discussion of the two databases and each of the three areas of concern follow.

The Transuranic Waste DataBase (TWDB) contains fissile material content data for the approximately 73,000 drums, 10,000 boxes and 500 bins of Rocky Flats waste stored at the RWMC. Of this waste, approximately 17,000 drums have been assayed by INEL with the data stored in the RKIVE database. Consistency in the ${ }^{239} \mathrm{Pu}$ gram content for these 17,000 drums in these two databases shows that the margin of error is relatively small compared to the margin of safety but there is no data or basis for validating the accuracy of the non RF drums, the boxes or the bins. However, the non RF drums contain only $2.0 \mathrm{~g}{ }^{239} \mathrm{Pu}$ per drum (less than one half as much as the $5.5 \mathrm{~g}{ }^{239} \mathrm{Pu}$ per Rocky Flats drum) and the boxes and bins contain even less $\left(0.01 \mathrm{~g}^{239} \mathrm{Pu}\right.$ per lb and $0.007 \mathrm{~g}{ }^{239} \mathrm{Pu}$ per lb compared to $0.018 \mathrm{~g}^{239} \mathrm{Pu}$ per $\mathrm{lb}$ in the RF drums). The margin of safety, as will be demonstrated, is very large for Rocky Flats drums and should be even larger for the more lightly loaded containers.

Fissile material content data derived from INEL assay of 17,152 waste drums is found in the RKIVE database. Of these drums, 17,073 can be identified in the TWDB which gives fissile content reported by Rocky Flats. All of the drums cannot be identified because in some cases the label has become illegible. In these cases, new identification numbers were assigned for the RKIVE database. Content codes do not always match because the content code was revised in the RKIVE database but not in the TWDB if the Real Time Radiography (RTR) indicated an error in content coding. Finally, the sum of the number of drums in individual matrix groups does not match the total because some drums are coded "unknown." It is also noted that for some of the early Rocky Flats shipments, the fissile content of the individual drums are actually averages for the entire shipment; they are not individual drum determinations. Thus, a few numbers do not match but none of these factors significantly affect the analysis of the accuracy of fissile content data of more than 17,000 drums. 
For the two databases, gram content distribution curves are given in Figure 6 and gram content and concentration data are given in Table 15. Both the distribution and the gram content for the same 17,000 drums in the TWDB and the RKIVE are in excellent agreement. The average content per drum is $8.0 \mathrm{~g}^{239} \mathrm{Pu}$ for the Rocky Flats data and $7.8 \mathrm{~g}^{239} \mathrm{Pu}$ for INEL data, a difference of only $2.6 \%$.

However, the INEL average does not include the drums awaiting assay as they have been placed in a separate database. Assuming these drums each contain $200 \mathrm{~g}{ }^{239} \mathrm{Pu}$ does not significantly affect the average but does narrow the small difference between the RF and INEL fissile content data.

The distribution curves show a small difference in the two data sets below $10 \mathrm{~g}{ }^{239} \mathrm{Pu}$ per drum but converges to near identical averages above $10 \mathrm{~g}{ }^{239} \mathrm{Pu}$ per drum. Furthermore, RF and INEL data show that $98.3 \%$ and $98.4 \%$ of the drums, respectively, contain less than $100 \mathrm{~g}{ }^{239} \mathrm{Pu}$. Both data sets show that $99.4 \%$ of the drums contain less than $150 \mathrm{~g}{ }^{239} \mathrm{Pu}$. The percentage of drums that might contain greater than $200 \mathrm{~g}{ }^{239} \mathrm{Pu}$ cannot be determined from the RF curve because the limit cutoff causes a sharp deviation from the log normal distribution characteristic of the fissile loadings. However, it does appear that both data sets provide evidence that nearly all (greater than $99.9 \%$ ) drums contain less than $200 \mathrm{~g}^{239} \mathrm{Pu}$.

The data in Table 15 is broken into eight different content groups. Included are average ${ }^{239} \mathrm{Pu}$ gram content per drum values and ratios of INEL values to Rocky Flats values. Also included for each content group are the threshold ${ }^{239} \mathrm{Pu}$ concentrations ( $75 \%$ of critical; See Table 4$)$, average concentrations (derived from the known matrix weight and the ${ }^{239} \mathrm{Pu}$ gram content taken from the Rocky Flats database), and margins of safety expressed as ratios of threshold concentration to actual concentration derived from the TWDB (Rocky Flats data).

The averages of the different content groups did not agree as well as the overall average content. The ratios of INEL to RF mass values ranged from 0.5 to 1.4 , less than a factor of two. These differences are small when compared to ratios of proposed threshold concentrations $(75 \%$ of critical) to actual concentrations which range from 2.1 to 170 , excluding the results for graphite waste. This range is highly skewed with most of the drums having very large safety factors. [The neutron cross sections for graphite are so small that very dilute concentrations have high reactivities. However, all existing graphite drums are shown to remain safely subcritical when configured in a single location within an infinite waste matrix. (See Section 6.2.2)]

There is not likely to be a strong bias in one direction in either data set because the different measurement techniques performed by different personnel would not result in the same bias. More 


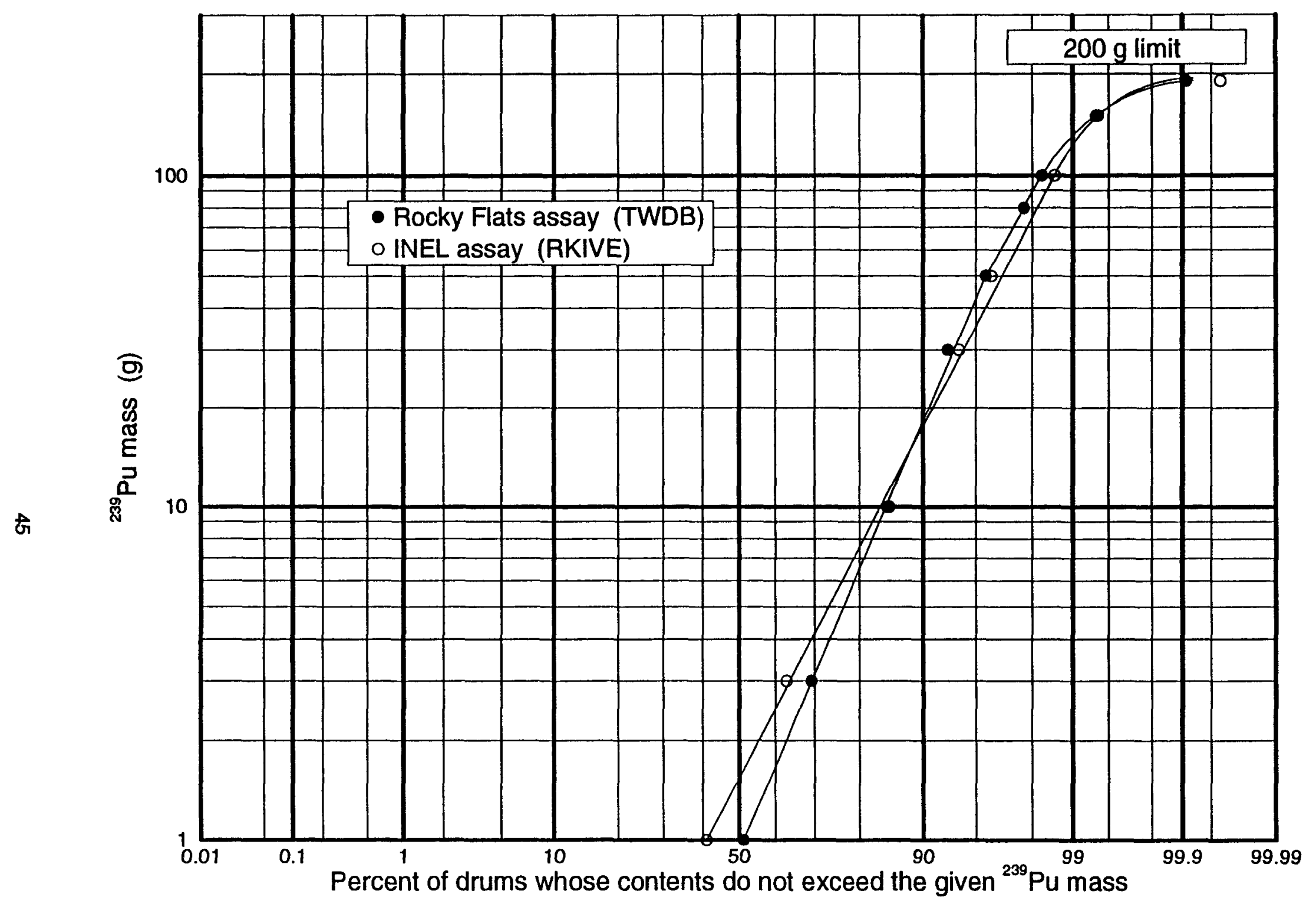

Figure 6. Distribution of ${ }^{239} \mathrm{Pu}$ in assayed drums 
Table 15. Fissile content and concentrations of assayed drums.

\begin{tabular}{|c|c|c|c|c|c|c|c|c|c|}
\hline \multirow{2}{*}{\multicolumn{2}{|c|}{ Matrix group }} & \multicolumn{5}{|c|}{${ }^{299} \mathrm{Pu}$ content of assayed drums } & \multirow{2}{*}{\multicolumn{3}{|c|}{${ }^{230} \mathrm{Pu}$ concentration }} \\
\hline & & \multicolumn{2}{|c|}{ INEL assay } & \multicolumn{2}{|c|}{$\mathrm{RF}$ assay } & \multirow{2}{*}{$\begin{array}{c}\text { Ratio } \\
\text { (INELRF) }\end{array}$} & & & \\
\hline Number & Material & $\#$ & $\begin{array}{l}\text { Average mass } \\
\text { (g) }\end{array}$ & $\#$ & $\begin{array}{l}\text { Average mass } \\
\text { (g) }\end{array}$ & & $\begin{array}{l}\text { Threshold } \\
\text { (g Pulb matrix) }\end{array}$ & $\begin{array}{c}\text { RF average } \\
\text { (g Pu/b matrix) }\end{array}$ & $\begin{array}{c}\text { Ratio } \\
\text { (Threshold/RF) }\end{array}$ \\
\hline 1 & water & 0 & 0.0 & 0 & 0.0 & & 2.4 & 0.0 & \\
\hline 2 & polyethylene & 2242 & 1.95 & 2212 & 3.8 & 0.51 & 3.1 & 0.018 & 170 \\
\hline 3 & graphite & 834 & 19.9 & 822 & 20.3 & 0.98 & 0.02 & 0.095 & 0.21 \\
\hline 4 & glass, slag & 5212 & 3.3 & 4406 & 2.3 & 1.4 & $\begin{array}{ll}\left(\mathrm{SiO}_{2}\right) & 0.15^{\mathrm{b}} \\
(\mathrm{MgO}) & 0.09^{\mathrm{b}}\end{array}$ & 0.043 & $\begin{array}{l}3.5 \\
2.1\end{array}$ \\
\hline 5 & cellulose & 2403 & 19.6 & 2403 & 23.1 & 0.85 & 1.3 & 0.07 & 19 \\
\hline 6 & concrete $^{\circ}$ & 5636 & 5.8 & 6421 & 4.1 & 1.4 & 0.56 & 0.010 & 56 \\
\hline 7 & metals & 672 & 10.5 & 657 & 14.1 & 0.74 & 0.82 & 0.078 & 10.5 \\
\hline 8 & salts & 44 & 100.5 & 44 & 144.2 & 0.70 & 5.53 & 0.51 & 10.8 \\
\hline 9 & brick & 109 & 43.0 & 108 & 38.4 & 1.12 & 0.23 & 0.045 & 5.1 \\
\hline all & & 17152 & 7.8 & 17073 & 8.0 & & & 0.018 & \\
\hline
\end{tabular}

a $75 \%$ of critical concentration as given in Table 4

b Threshold concentrations were calculated for glass using both $\mathrm{SO}_{2}$ and $\mathrm{MgO}$

Ordinary concrete as given in the KENO Hansen-Roach cross section library 
likely, in some cases the bias would be conservative and in others non conservative. The fact that the INEL content is higher than the RF content in some groups and lower in others confirms this observation. In any case, the largest difference between the two data sets is very small compared to the safety factors. Therefore, an adequate margin of safety exists for the large stacks of drums at the RWMC without taking credit for the structural integrity of the drums. It is emphasized that the average gram content and resulting concentration is the parameter of concern for this margin of safety as it has been demonstrated that homogeneity is conservative.

The second area of concern is the margin of safety for drums that exceed threshold concentrations. The number of drums that exceed threshold concentrations was determined from the distribution data and the results from SCAMP and KENO-V.a calculations for the different content groups. An additional margin of safety is introduced by examining numbers of drums that exceed $37.5 \%$ rather than $75 \%$ of the critical concentration. A summary of data used for this comparison is given in Table 16. An inherent assumption in this approach is that all of the errors in the database are biased and the reported concentration values are lower than actual concentrations. As previously discussed, even if large errors are present, they are more likely to be random so that average values would approach real values. The conservative modeling introduces additional margins of safety. For example, there are 209 drums classified as metal with concentrations exceeding $37.5 \%$ of the critical concentration. In this example, the contents of each drum were represented with the maximum concentration and maximum weight resulting in $443 \mathrm{~g}{ }^{239} \mathrm{Pu}$ per drum. A calculation of the actual content for each range in the distribution data indicates that the average for these drums is only $79 \mathrm{~g}$ ${ }^{239} \mathrm{Pu}$ per drum. This conservative modeling results in an additional factor of 5.6 in safety. (Where multiple concentration levels were required, margins of safety are smaller.) It is also noted that at these higher gram loadings there was excellent agreement between the Rocky Flats data and the INEL assay data. In addition, it is extremely improbable that a significant portion of the drums with relatively higher ${ }^{239} \mathrm{Pu}$ concentrations would be in one location. It is clear that criticality is not a concern for the most reactive configuration of drums that exceed the threshold concentration even if large errors exist in the database for individual drums.

The margin of error for the third area of concern, that of single overloaded drums, is also adequate but requires engineering judgement rather than an examination of the database. Single overloaded drums are discussed in Section 6.4 and are not addressed here.

It is of interest to note that the RF and the INEL data (shown in Table 15) indicate, when adjusted for the same number of drums, a total mass of 138 and $134 \mathrm{~kg}$ of ${ }^{239} \mathrm{Pu}$, respectively. Nevertheless, this quantity of fissile material has been conclusively shown to be distributed through the 
Table 16. Percentage of drums exceeding $37.5 \%$ the calculated critical values.

\begin{tabular}{|c|c|c|c|c|c|}
\hline \multicolumn{2}{|c|}{ Matrix group } & \multirow{3}{*}{$\begin{array}{c}37.5 \% \text { of critical } \\
{ }^{230} \mathrm{Pu} \\
\text { concentration } \\
\text { (g Pu/b matrix) }\end{array}$} & \multicolumn{3}{|c|}{ Drums } \\
\hline \multirow[t]{2}{*}{ Number } & \multirow[t]{2}{*}{ Material } & & \multirow{2}{*}{$\begin{array}{l}\text { Total in matrix } \\
\text { group } \\
(\#)\end{array}$} & \multicolumn{2}{|c|}{$\begin{array}{c}\text { Exceeding } 37.5 \% \text { of critical } \\
\text { concentration }\end{array}$} \\
\hline & & & & $\#$ & $\%$ \\
\hline 1 & water & 1.2 & 0 & 0 & 0.0 \\
\hline 2 & polyethylene & 1.55 & 11376 & 1 & 0.009 \\
\hline 3 & graphite & 0.01 & 2365 & 2158 & $91.25^{\circ}$ \\
\hline 4 & $\begin{array}{l}\text { glass, slag }\left(\mathrm{SiO}_{2}\right) \\
\text { glass slag }(\mathrm{MgO})\end{array}$ & $\begin{array}{l}0.075 \\
0.045\end{array}$ & $\begin{array}{l}9904 \\
9904\end{array}$ & $\begin{array}{l}1015 \\
1202\end{array}$ & $\begin{array}{l}10.25 \\
12.14\end{array}$ \\
\hline 5 & cellulose & 0.65 & 16408 & 484 & 2.95 \\
\hline 6 & concrete $\theta^{b}$ & 0.28 & 27526 & 138 & 0.50 \\
\hline 7 & metal (Al) & 0.41 & 4030 & 209 & 5.19 \\
\hline 8 & salts & 2.765 & 88 & 10 & 11.36 \\
\hline 9 & brick $\left(\mathrm{Al}_{2} \mathrm{O}_{3}\right)$ & 0.12 & 1031 & 136 & 13.19 \\
\hline all & & & $72737^{\circ}$ & 4338 & 5.96 \\
\hline
\end{tabular}

a The mayority of the waste drums with contents characterized as graphite have plutonium concentrations that exceed $375 \%$ of the minımum critıcal concentration However, these drums are shown to be salely subcritical when more realistic representations are used

b Ordinary concrete as given in the KENO Hansen-Roach cross section library

c This is the total number given in the database for "all" drums Due to unknown contents in a few drums, the sum of the number of drums in all matnx groups 1872,728 
waste matrix in concentrations that are far below critical. Only a very small percentage of the drums have high gram loadings so that accumulations of highly concentrated drums is extremely improbable. It is concluded that the RF database is adequate for the calculations considering the large margins of safety, the agreement with the INEL assay data, and the conservatisms in the criticality calculations and modeling. It is concluded that margins of safety are such that criticality at the RWMC is incredible. 


\subsection{DESIGN FEATURES (PASSIVE \& ACTIVE) AND ADMINISTRATIVELY CONTROLLED LIMITS AND REQUIREMENTS}

The conclusions stated in this evaluation do not rely upon design features or administrative controls. For most cases, fully infinite systems are modeled which do not incorporate container dimensions. When the containers are modeled explicitly, they are in conservative, close-packed or fully compressed, and infinite arrangements. No special design features or administratively controlled limits are required for handling drums which are now in storage.

Based on the database information available, the results reported herein confirm that the waste drums, bins, and boxes currently stored at the RWMC will remain safely subcritical if rearranged, restacked, or otherwise handled. This is true for all drums presently in storage, including those suspected to be in violation of the $\mathbf{2 0 0}$ gram mass limit as long as they do not contain over 380 grams ( $75 \%$ of the minimum critical mass of plutonium in water) of fissile material. If encountered, such drums will require individual evaluation to determine a safe disposition. The $\mathbf{2 0 0}$ gram limit has been established for shipping purposes.

Drums may be accepted for storage only if: (1) The content code is included in those described in Table 2 and Appendix C, (2) The concentration of fissile material is no greater than that listed in Table 17, and (3) No single drum contains over 380 grams of fissile material. Since the analysis was based on fully infinite systems, any number of drums may be accepted if they meet these conditions. Other criteria may be established for specific waste streams provided criticality analyses that demonstrate an adequate margin of safety without operational or configuration controls have been reviewed and approved by DOE. 
Table 17. Acceptance criteria for future receipt of waste.

\begin{tabular}{|c|c|c|c|}
\hline \multicolumn{3}{|c|}{ Matrix group } & \multirow{2}{*}{$\begin{array}{l}\text { Threshold concentration } \\
\text { (g Pu/b matrix) }\end{array}$} \\
\hline Number & Material & $\begin{array}{l}\text { Density } \\
\left(\mathrm{g} / \mathrm{cm}^{3}\right)\end{array}$ & \\
\hline 1 & water & 1.0 & 2.4 \\
\hline 2 & polyethylene & 0.92 & 3.1 \\
\hline 3 & graphite & 1.6 & 0.02 \\
\hline 4 & glass, slag & 3.58 & 0.09 \\
\hline 5 & cellulose & 0.64 & 1.3 \\
\hline 6 & concrete & 2.37 & 0.56 \\
\hline 7 & metal & 2.7 & 0.82 \\
\hline 8 & salts & 2.16 & 5.53 \\
\hline 9 & brick & 3.965 & 0.23 \\
\hline
\end{tabular}

a Ordinary concrele as given in the KENO Hansen-Roach cross section hbrary 


\subsection{SUMMARY AND CONCLUSIONS}

The methodology and conclusions in this report are based primarily on the assumption that the existing database is reasonably accurate and reliable. As drums are assayed, more information becomes available which may help verify that this is indeed the case. However, until that information is available for a large number of drums, possible inaccuracy in the database remains an issue. The question of possible inaccuracies is addressed by: comparing Rocky Flats data with INEL assay values in Section 6.5; overestimating the number of drums exceeding the threshold values; and demonstrating through calculations that even if major discrepancies and large error factors exist, there are adequate conservatisms and the conclusions remain valid.

The calculational models used in this evaluation contain several conservatisms. Among them are: (1) Limits are established for fully infinite homogeneous systems, (2) Drums are categorized by the most reactive component of the waste matrix material (highly absorbing impurities are neglected), and (3) Fissile concentrations and net drum weights were represented, in most cases, as if all drums had the contents equivalent to the maximum values in the database.

The results from calculations included in this evaluation demonstrate that stored waste under current and any credible, foreseeable conditions, including total drum collapse, will remain subcritical based on the concentrations of fissile material actually present for the types of waste stored at the facility. The results and conclusions presented in this report will be valid so long as future waste shipments are of the same general type and do not exceed the acceptance criteria reported in Section 7.0 of this report.

An independent review of this evaluation verified the calculational results of this CSE and concluded that it provides an adequate basis for criticality safety of TRU waste stored at the RWMC. A copy of the independent review summary is given in Appendix F. 


\subsection{REFERENCES}

1. N. L. Pruvost and M. L. Prueitt, The Hansen-Roach Cross Sections - A Graphical Representation, LALP-88-20, Los Alamos National Laboratory, October 1988.

2. L. M. Petrie and N. F. Landers, KENO-V.a - An Improved Monte Carlo Criticality Program with Supergrouping, NUREG/CR-0200, Oak Ridge National Laboratory, December 1984.

3. L. M. Petrie and N. F. Landers, CSAS4: An Enhanced Criticality Safety Analysis Module with Optimum Pitch Search Option, NUREG/CR-0200,Oak Ridge National Laboratory, December 1984.

4. J. Briesmeister (Editor), MCNP-A General Monte Carlo Code for Neutron and Photon Transport, Version 3A, LA-7396-M, Los Alamos National Laboratory, September 1986.

5. R.C. Little and R.E. Seamon, Summary of Cross-Section Data Provided for MCNP, Version 3A, Informal Notes by R.W. Roussin, March 1987.

6. R. A. Grimesey, D. W. Nigg, R. L. Curtis, COMBINE/PC-A Portable ENDF/B Version 5 Neutron Spectrum and Cross-Sections Generation Program Rev. 1, EGG-2589, Idaho National Engineering Laboratory, February 1991.

7. SCALE: A Modular Code System for Performing Standardized Computer Analyses for Licensing Evaluation, RSIC Computer Code Collection, CCC-545, NUREG/CR-0200, Rev.4, ORNL/NUREG/CSD-2/R4, Oak Ridge National Laboratory.

8. H. C. Paxton and N. L. Pruvost, Critical Dimensions of Systems Containing U-235, ${ }^{239} \mathrm{PU}$, and U-233, LA-10860-MS, Los Alamos National Laboratory, July 1987. 
APPENDIX A:

MATERIALS AND COMPOSITIONS 


\section{SUMMARY OF TABLES IN APPENDIX A}

A-1. Atom densities used to evaluate waste that is characterized as water $\left(\mathrm{H}_{2} \mathrm{O} ; \mathrm{p}=\mathbf{1 . 0 \mathrm { g } / \mathrm { cm } ^ { 3 } ) \ldots \ldots \ldots \ldots \ldots \ldots \ldots \ldots \ldots \ldots \ldots \ldots \ldots \ldots \ldots \ldots \ldots \ldots \ldots}\right.$

A-2. Atom densities used to evaluate waste that is characterized as polyethylene

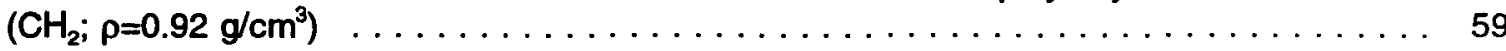

A-3. Atom densities used to evaluate waste that is characterized as graphite $\left(\rho=1.6 \mathrm{~g} / \mathrm{cm}^{3}\right) \ldots 60$

A-4. Atom densities used to evaluate waste that is characterized as silicon dioxide

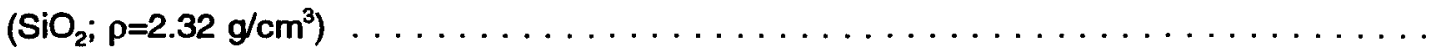

A-5. Atom densities used to evaluate waste that is characterized as magnesium oxide

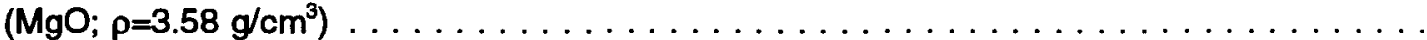

A-6. Atom densities used to evaluate waste that is characterized as cellulose $\left(\mathrm{C}_{6} \mathrm{H}_{10} \mathrm{O}_{5} ; \rho=3.58 \mathrm{~g} / \mathrm{cm}^{3}\right)$.

A-7. Atom densities used to evaluate waste that is characterized as concrete $\left(\rho=2.37 \mathrm{~g} / \mathrm{cm}^{3}\right)$. .

A-8. Atom densities used to evaluate waste that is characterized as aluminum $\left(\rho=2.70 \mathrm{~g} / \mathrm{cm}^{3}\right)$

A-9. Atom densities used to evaluate waste that is characterized as salts $\left(\rho=2.16 \mathrm{~g} / \mathrm{cm}^{3}\right) \ldots \ldots 3$

A-10. Atom densities used to evaluate waste that is characterized as aluminum oxide $\left(\mathrm{Al}_{2} \mathrm{O}_{3} ; \rho=3.965 \mathrm{~g} / \mathrm{cm}^{3}\right)$

A-11. Atom densities used to evaluate waste that is characterized as graphite $\left(C ; 1.6 \mathrm{~g} / \mathrm{cm}^{3}\right)$ with plutonium concentrations that exceed $37.5 \%$ of the calculated critical concentration .

A-12. Atom densities used to evaluate waste that is characterized as glass $\left(\mathrm{SiO}_{2} ; 2.32 \mathrm{~g} / \mathrm{cm}^{3}\right)$ with plutonium concentrations that exceed $37.5 \%$ of the calculated critical concentration

A-13. Atom densities used to evaluate waste that is characterized as glass (MgO; $3.58 \mathrm{~g} / \mathrm{cm}^{3}$ ) with plutonium concentrations that exceed $37.5 \%$ of the calculated critical concentration .

A-14. Atom densities used to evaluate waste that is characterized as cellulose $\left(\mathrm{C}_{6} \mathrm{H}_{10} \mathrm{O}_{5} ; 0.64\right.$ $\mathrm{g} / \mathrm{cm}^{3}$ ) with plutonium concentrations that exceed $37.5 \%$ of the calculated critical concentration

A-15. Atom densities used to evaluate waste that is characterized as concrete $\left(2.37 \mathrm{~g} / \mathrm{cm}^{3}\right)$ with plutonium concentrations that exceed $37.5 \%$ of the calculated critical concentration ..

A-16. Atom densities used to evaluate waste that is characterized as metal (Al; $2.70 \mathrm{~g} / \mathrm{cm}^{3}$ ) with plutonium concentrations that exceed $37.5 \%$ of the calculated critical concentration . . 
Table A-1. Atom densities used to evaluate waste that is characterized as water $\left(\mathrm{H}_{2} \mathrm{O} ; \rho=1.0 \mathrm{~g} / \mathrm{cm}^{3}\right)$.

\begin{tabular}{|c|c|c|c|c|}
\hline $\begin{array}{l}\text { Weste } \\
\text { Component }\end{array}$ & $\begin{array}{l}\text { Plutonium } \\
\text { Concentration } \\
\text { (g Pu/b Matrix) }\end{array}$ & $\begin{array}{c}\text { SCAMP } \\
\text { Library } \\
\text { ID }\end{array}$ & $\begin{array}{l}\text { KENO } \\
\text { Library } \\
\text { ID }\end{array}$ & $\begin{array}{l}\text { Atom Denaity } \\
\text { (Volume Fraction) }\end{array}$ \\
\hline \multirow[t]{12}{*}{${ }^{200} \mathrm{Pu}$} & 1.5 & 616 & 94916 & $8.3321-6$ \\
\hline & 2.0 & 616 & 94916 & $1.1108-5$ \\
\hline & 2.4 & 616 & 94916 & $1.3331-5$ \\
\hline & 2.5 & 616 & 94916 & $1.3888-5$ \\
\hline & 3.0 & 615 & 94915 & 4.50416 \\
\hline & & 616 & 94916 & $1.2160-5$ \\
\hline & 3.2 & 615 & 94915 & $7.2170-6$ \\
\hline & & 616 & 94916 & $1.0532-5$ \\
\hline & 3.5 & 615 & 94915 & $1.1446-5$ \\
\hline & & 616 & 94916 & $7.9953-6$ \\
\hline & 4.0 & 615 & 94915 & $1.8392-5$ \\
\hline & & 616 & 94916 & $3.8278-6$ \\
\hline $\mathrm{H}_{2} \mathrm{O}$ & - & 708 & 502 & $(1.0)$ \\
\hline
\end{tabular}

Table A-2. Atom densities used to evaluate waste that is characterized as polyethylene $\left(\mathrm{CH}_{2} ; \rho=0.92 \mathrm{~g} / \mathrm{cm}^{3}\right)$.

\begin{tabular}{|c|c|c|c|c|}
\hline $\begin{array}{l}\text { Wrete } \\
\text { Component }\end{array}$ & $\begin{array}{l}\text { Plutonium } \\
\text { Concentration } \\
\text { (g Pu/lb Matuix) }\end{array}$ & $\begin{array}{c}\text { SCAMP } \\
\text { LIbrany } \\
\text { ID }\end{array}$ & $\begin{array}{l}\text { KENO } \\
\text { Libray } \\
\text { ID }\end{array}$ & $\begin{array}{l}\text { Atom Density } \\
\text { (Volume Fraction) }\end{array}$ \\
\hline \multirow[t]{9}{*}{${ }^{200} \mathrm{Pu}$} & 2.0 & 616 & 94916 & $1.0221-5$ \\
\hline & 2.5 & 616 & 94916 & $1.2776-5$ \\
\hline & 3.0 & 616 & 94916 & $1.5331-5$ \\
\hline & 3.1 & 616 & 94916 & $1.5842-5$ \\
\hline & 3.5 & 616 & 94916 & $1.7886-5$ \\
\hline & 4.0 & 615 & 94915 & $5.9085-6$ \\
\hline & & 616 & 94916 & $1.4533-5$ \\
\hline & 4.5 & 615 & 94915 & $1.2295-5$ \\
\hline & & 616 & 94916 & $1.0701-5$ \\
\hline $\mathrm{CH}_{2}$ & -. & 706 & 402 & $(1.0)$ \\
\hline
\end{tabular}


Table A-3. Atom densities used to evaluate waste that is characterized as graphite $\left(\rho=1.6 \mathrm{~g} / \mathrm{cm}^{3}\right)$.

\begin{tabular}{|c|c|c|c|c|}
\hline $\begin{array}{c}\text { Waste } \\
\text { Component }\end{array}$ & $\begin{array}{c}\text { Piutonium } \\
\text { Concentration } \\
\text { (g Pu/b Matrix) }\end{array}$ & $\begin{array}{c}\text { SCAMP } \\
\text { Llbrary } \\
\text { ID }\end{array}$ & $\begin{array}{c}\text { KENO } \\
\text { Llbrary } \\
\text { ID }\end{array}$ & $\begin{array}{c}\text { Atom Density } \\
\text { (Volume Fraction) }\end{array}$ \\
\hline \multirow[t]{20}{*}{${ }^{200} \mathrm{Pu}$} & 0.02 & 616 & 94916 & $1.7770-7$ \\
\hline & 0.025 & 616 & 94916 & $2.2220-7$ \\
\hline & 0.03 & 616 & 94916 & $2.6660-7$ \\
\hline & 0.05 & 616 & 94916 & $4.4440-7$ \\
\hline & 0.15 & 616 & 94916 & $1.3328-6$ \\
\hline & 0.20 & 616 & 94916 & $1.7770-6$ \\
\hline & 0.50 & 615 & 94915 & $1.3730-6$ \\
\hline & & 616 & 94916 & $3.0710-6$ \\
\hline & 0.56 & 615 & 94915 & $2.9533-6$ \\
\hline & & 616 & 94916 & $2.0237-6$ \\
\hline & 0.60 & 615 & 94915 & $3.8418-6$ \\
\hline & & 616 & 94916 & $1.4907-6$ \\
\hline & 0.80 & 614 & 94914 & $2.3499-6$ \\
\hline & & 615 & 94915 & $4.7600-6$ \\
\hline & 1.00 & 614 & 94914 & $7.6739-6$ \\
\hline & & 615 & 94915 & $1.2110-6$ \\
\hline & 1.50 & 613 & 94913 & $7.6759-6$ \\
\hline & & 614 & 94914 & $5.6541-6$ \\
\hline & 2.00 & 613 & 94913 & $1.6553-5$ \\
\hline & & 614 & 94914 & $1.2171-6$ \\
\hline$c$ & -- & 8 & 6100 & $8.0233-2^{\circ}$ \\
\hline
\end{tabular}

a Additional calculations were performed in which graphite volume fractions less than 10 were used Atom densities for these cases are obtained by multiplying the carbon atom density given in this table by the volume fraction 
Table A-4. Atom densities used to evaluate waste that is characterized as silicon dioxide $\left(\mathrm{SiO}_{2} ; \rho=2.32 \mathrm{~g} / \mathrm{cm}^{3}\right)$.

\begin{tabular}{|c|c|c||}
\hline Waste Component ID & $\begin{array}{c}\text { Plutonlum } \\
\text { Concentration } \\
\text { (g Pulb Matrix) }\end{array}$ & $\begin{array}{c}\text { Atom Donsity } \\
\text { (Nolume Fraction) }\end{array}$ \\
\hline \hline Pu-239 & 0.10 & $1.2887-6$ \\
& 0.12 & $1.5464-6$ \\
& 0.14 & $1.8042-6$ \\
& 0.15 & $1.9330-6$ \\
& 0.16 & $2.0619-6$ \\
& 0.20 & $2.5774-6$ \\
& 0.25 & $3.2218-6$ \\
\hline $\mathrm{Si}$ & -- & $2.3256-2^{b}$ \\
$\mathrm{O}$ & -- & $4.6513-2^{b}$ \\
\hline
\end{tabular}

SCALE Standard Compostion Library ID used for KENO-V a calculatıons

Additional calculations were performed in which silicon dioxide volume fractions less than 10 were used Atom densities for these cases

are obtained by multuplying the $\mathrm{SI}_{\mathrm{I}}$ and $\mathrm{O}$ atom densities given in this table by the volume fraction

Table A-5. Atom densities used to evaluate waste that is characterized as magnesium oxide ( $\mathrm{MgO} ; \rho=3.58 \mathrm{~g} / \mathrm{cm}^{3}$ ).

\begin{tabular}{|c|c|c||}
\hline Wasto Component ID & $\begin{array}{c}\text { Plutonlum } \\
\text { Concontration } \\
\text { (g Pulb Matrix) }\end{array}$ & $\begin{array}{c}\text { Atom Density } \\
\text { (Nolume Fraction) }\end{array}$ \\
\hline \hline Pu-239 & 0.05 & $9.9435-7$ \\
& 0.07 & $1.3921-6$ \\
& 0.10 & $1.9887-6$ \\
& 0.12 & $2.3864-6$ \\
& 0.13 & $2.5853-6$ \\
& 0.15 & $2.9831-6$ \\
& 0.20 & $3.9774-6$ \\
& 0.25 & $4.9718-6$ \\
$\mathrm{Mg}$ & 0.30 & $5.9661-6$ \\
\hline $\mathrm{O}$ & -- & $5.3499-2$ \\
\hline
\end{tabular}

a

SCALE Standard Composition Library ID used for KENO-V a calculations 
Table A-6. Atom densities used to evaluate waste that is characterized as cellulose $\left(\mathrm{C}_{6} \mathrm{H}_{10} \mathrm{O}_{5} ; \rho=0.64 \mathrm{~g} / \mathrm{cm}^{3}\right)$.

\begin{tabular}{|c|c|c|c|c|}
\hline $\begin{array}{l}\text { Weste } \\
\text { Component }\end{array}$ & $\begin{array}{l}\text { Plutonium } \\
\text { Concentration } \\
\text { (9 Pu/lb Matrb) }\end{array}$ & $\begin{array}{l}\text { SCAMP } \\
\text { Librany } \\
\text { ID }\end{array}$ & $\begin{array}{l}\text { KENO } \\
\text { Llbrary } \\
\text { ID }\end{array}$ & $\begin{array}{c}\text { Atom Denalty } \\
\text { (Volume Fraction) }\end{array}$ \\
\hline \multirow[t]{11}{*}{${ }^{200} \mathrm{Pu}$} & 1.0 & 616 & 94916 & $3.5550-6$ \\
\hline & 1.3 & 616 & 94916 & $4.6216-6$ \\
\hline & 1.5 & 616 & 94916 & $5.3325-6$ \\
\hline & 1.7 & 615 & 94915 & $1.8392-7$ \\
\hline & & 616 & 94916 & $5.8596-6$ \\
\hline & 2.0 & 615 & 94915 & $2.8500-6$ \\
\hline & & 616 & 94916 & $4.2600-6$ \\
\hline & 2.5 & 615 & 94915 & $7.2930-6$ \\
\hline & & 616 & 94916 & $1.5945-6$ \\
\hline & 3.0 & 615 & 94915 & $2.1422-6$ \\
\hline & & 616 & 94916 & $8.5228-6$ \\
\hline C & -- & 8 & 6100 & $1.4260-2$ \\
\hline $\mathrm{H}$ & - & 2 & 1102 & $2.3780-2$ \\
\hline 0 & -- & 10 & 8100 & $1.1890-2$ \\
\hline
\end{tabular}

Table A-7. Atom densities used to evaluate waste that is characterized as concrete $\left(\rho=2.37 \mathrm{~g} / \mathrm{cm}^{3}\right)$.

\begin{tabular}{|c|c|c|c|c|}
\hline $\begin{array}{c}\text { Waste } \\
\text { Component }\end{array}$ & $\begin{array}{c}\text { Plutonium } \\
\text { Concentration } \\
\text { (g Pu/lb Matrix) }\end{array}$ & $\begin{array}{c}\text { SCAMP } \\
\text { Llbrary } \\
\text { ID }\end{array}$ & $\begin{array}{c}\text { KENO } \\
\text { Library } \\
\text { ID }\end{array}$ & $\begin{array}{c}\text { Atom Density } \\
\text { (Volume Fraction) }\end{array}$ \\
\hline \hline${ }^{230} \mathrm{Pu}$ & 0.5 & 615 & 94915 & $3.2034-6$ \\
& 0.6 & 616 & 94916 & $3.3788-6$ \\
& & 615 & 94915 & $1.4941-6$ \\
& 0.75 & 616 & 94916 & $3.1135-6$ \\
& & 615 & 94915 & $5.7599-6$ \\
& 0.8 & 616 & 94916 & $5.0852-6$ \\
& & 615 & 94915 & $5.4464-6$ \\
\hline
\end{tabular}


Table A-8. Atom densities used to evaluate waste that is characterized as aluminum $\left(\rho=2.70 \mathrm{~g} / \mathrm{cm}^{3}\right)$.

\begin{tabular}{|c|c|c|c|c|}
\hline $\begin{array}{l}\text { Waste } \\
\text { Component }\end{array}$ & $\begin{array}{c}\text { Plutonium } \\
\text { Concentration } \\
\text { (g Pu/b Matrix) }\end{array}$ & $\begin{array}{c}\text { SCAMP } \\
\text { Library } \\
\text { ID }\end{array}$ & $\begin{array}{l}\text { KENO } \\
\text { Llbrary } \\
\text { ID }\end{array}$ & $\begin{array}{c}\text { Atom Density } \\
\text { (Volume Fraction) }\end{array}$ \\
\hline \multirow[t]{5}{*}{${ }^{200} \mathrm{Pu}$} & 0.5 & $\begin{array}{l}615 \\
616\end{array}$ & $\begin{array}{l}94915 \\
94916\end{array}$ & $\begin{array}{l}6.8508-6 \\
6.4799-7\end{array}$ \\
\hline & 0.75 & $\begin{array}{l}615 \\
616\end{array}$ & $\begin{array}{l}94915 \\
94916\end{array}$ & $\begin{array}{l}7.7399-6 \\
3.5078-6\end{array}$ \\
\hline & 1.0 & $\begin{array}{l}615 \\
616\end{array}$ & $\begin{array}{l}94915 \\
94916\end{array}$ & $\begin{array}{l}4.2080-6 \\
1.0789-5\end{array}$ \\
\hline & 1.5 & $\begin{array}{l}615 \\
616\end{array}$ & $\begin{array}{l}94915 \\
94916\end{array}$ & $\begin{array}{l}4.1574-6 \\
1.8339-5\end{array}$ \\
\hline & 2.0 & $\begin{array}{l}615 \\
616\end{array}$ & $\begin{array}{l}94915 \\
94916\end{array}$ & $\begin{array}{l}1.9104-5 \\
1.0891-5\end{array}$ \\
\hline Al & - & 14 & 13100 & $6.0271-2$ \\
\hline
\end{tabular}

Table A-9. Atom densities used to evaluate waste that is characterized as salts $\left(\rho=2.16 \mathrm{~g} / \mathrm{cm}^{3}\right)$.

\begin{tabular}{|c|c|c|c|c|}
\hline $\begin{array}{l}\text { Waste } \\
\text { Component }\end{array}$ & $\begin{array}{c}\text { Plutonium } \\
\text { Concentration } \\
\text { (g Pu/lb Matrix) }\end{array}$ & $\begin{array}{c}\text { SCANP } \\
\text { Library } \\
\text { ID }\end{array}$ & $\begin{array}{l}\text { KENO } \\
\text { Llbrary } \\
\text { ID }\end{array}$ & $\begin{array}{c}\text { Atom Density } \\
\text { (Volume Fraction) }\end{array}$ \\
\hline \multirow[t]{6}{*}{${ }^{230} \mathrm{Pu}$} & 5.0 & $\begin{array}{l}609 \\
610\end{array}$ & $\begin{array}{l}94909 \\
94910\end{array}$ & $\begin{array}{l}5.2237-5 \\
7.7536-6\end{array}$ \\
\hline & 5.5 & $\begin{array}{l}609 \\
610\end{array}$ & $\begin{array}{l}94909 \\
94910\end{array}$ & $\begin{array}{l}6.4194-5 \\
1.7948-6\end{array}$ \\
\hline & 6.1 & $\begin{array}{l}608 \\
609\end{array}$ & $\begin{array}{l}94908 \\
94909\end{array}$ & $\begin{array}{l}1.0711-5 \\
6.2477-5\end{array}$ \\
\hline & 6.5 & $\begin{array}{l}608 \\
609\end{array}$ & $\begin{array}{l}94908 \\
94909\end{array}$ & $\begin{array}{l}2.0245-5 \\
5.7743-5\end{array}$ \\
\hline & 7.0 & $\begin{array}{l}608 \\
609\end{array}$ & $\begin{array}{l}94908 \\
94909\end{array}$ & $\begin{array}{l}3.2162-5 \\
5.1825-5\end{array}$ \\
\hline & 8.0 & $\begin{array}{l}608 \\
609\end{array}$ & $\begin{array}{l}94908 \\
94909\end{array}$ & $\begin{array}{l}5.5996-5 \\
3.9988-5\end{array}$ \\
\hline $\mathrm{Na}$ & -- & 12 & 11100 & $1.1156-2$ \\
\hline $\mathrm{Ca}$ & - & 19 & 20100 & $5.8338-3$ \\
\hline $\mathrm{Cl}$ & - & 17 & 17100 & $2.2824-2$ \\
\hline
\end{tabular}


Table A-10. Atom densities used to evaluate waste that is characterized as aluminum oxide $\left(\mathrm{Al}_{2} \mathrm{O}_{3} ; \rho=3.965 \mathrm{~g} / \mathrm{cm}^{3}\right)$.

\begin{tabular}{||c|c|c||}
\hline Wasto Componont ID & $\begin{array}{c}\text { Plutonlum } \\
\text { Concontration } \\
\text { (g Pu/lb Matrix) }\end{array}$ & $\begin{array}{c}\text { Atom Donsity } \\
\text { (Nolumo Fraction) }\end{array}$ \\
\hline \hline Pu-239 & 0.20 & $4.4049-6$ \\
& 0.23 & $5.0656-6$ \\
& 0.25 & $5.5061-6$ \\
& 0.28 & $6.1668-6$ \\
& 0.30 & $6.6072-6$ \\
& 0.33 & $7.2679-6$ \\
& 0.37 & $8.1489-6$ \\
& 0.40 & $8.8097-6$ \\
\hline Al & -- & $4.6844-2$ \\
O & -- & $7.0266-2$ \\
\hline
\end{tabular}

Table A-11. Atom densities used to evaluate waste that is characterized as graphite $\left(C ; 1.6 \mathrm{~g} / \mathrm{cm}_{3}\right)$ with plutonium concentrations that exceed $37.5 \%$ of the calculated critical concentration.

\begin{tabular}{|c|c|c||}
\hline Waste Component ID & $\begin{array}{c}\text { Plutonium } \\
\text { Concentration } \\
\text { (g Pu/lb Matrix) }\end{array}$ & $\begin{array}{c}\text { Atom Donsity } \\
\text { (Atoms/barn-cm) }\end{array}$ \\
\hline Pu-239 & 1.27 & $1.1287-5$ \\
& 0.99 & $8.7986-6$ \\
& 0.85 & $7.5543-6$ \\
& 0.65 & $5.7768-6$ \\
& 0.54 & $4.7992-6$ \\
& 0.44 & $3.9105-6$ \\
\hline C & 0.34 & $3.0217-6$ \\
\hline
\end{tabular}


Table A-12. Atom densities used to evaluate waste that is characterized as glass $\left(\mathrm{SiO}_{2} ; 2.32 \mathrm{~g} / \mathrm{cm}^{3}\right)$ with plutonium concentrations that exceed $37.5 \%$ of the calculated critical concentration.

\begin{tabular}{|c|c|c||}
\hline Wasto Component ID & $\begin{array}{c}\text { Plutonlum } \\
\text { Concontration } \\
\text { (g Pulb Matrix) }\end{array}$ & $\begin{array}{c}\text { Atom Donsity } \\
\text { (Atoma/barn-cm) }\end{array}$ \\
\hline \hline Pu-239 & 2.03 & $2.6160-5$ \\
& 1.34 & $1.7268-5$ \\
& 0.95 & $1.2243-5$ \\
& 0.74 & $9.5362-6$ \\
& 0.55 & $7.0877-6$ \\
& 0.24 & $3.0928-6$ \\
& 0.15 & $1.9330-6$ \\
& $0.15^{\mathrm{b}}$ & $1.9330-6$ \\
\hline $\mathrm{Si}$ & -- & $2.3256-2$ \\
0 & -- & $4.6513-2$ \\
\hline
\end{tabular}

a SCALE Standard Compostion LIbrary ID used for KENO-V a calculations

b This plutonium concentration corresponds to $75 \%$ of the minimum critical plutonium concentration in a tully intinite glass environment and was used to represent surrounding waste material in all calculations that were performed to demonstrate the safety of existing drums that exceed threshold values 
Table A-13. Atom densities used to evaluate waste that is characterized as glass $\left(\mathrm{MgO} ; 3.58 \mathrm{~g} / \mathrm{cm}^{3}\right)$ with plutonium concentrations that exceed $37.5 \%$ of the calculated critical concentration.

\begin{tabular}{|c|c|c||}
\hline Wasto Component ID & $\begin{array}{c}\text { Plutonium } \\
\text { Concentration } \\
\text { (g Pu/lb Matrit) }\end{array}$ & $\begin{array}{c}\text { Atom Donsity } \\
\text { (Atoma/barn-cm) }\end{array}$ \\
\hline Pu-239 & 2.03 & $4.0468-5$ \\
& 1.34 & $2.6647-5$ \\
& 0.95 & $1.8891-5$ \\
& 0.74 & $1.4715-5$ \\
& 0.55 & $1.0937-5$ \\
& 0.24 & $4.7726-6$ \\
& 0.15 & $2.9829-6$ \\
0 & 0.10 & $1.9886-6$ \\
\hline
\end{tabular}

a

SCALE Standard Composition Library ID used lor KENO-V a calculations

Table A-14. Atom densities used to evaluate waste that is characterized as cellulose $\left(\mathrm{C}_{6} \mathrm{H}_{10} \mathrm{O}_{5} ; 0.64\right.$ $\mathrm{g} / \mathrm{cm}^{3}$ ) with plutonium concentrations that exceed $37.5 \%$ of the calculated critical concentration.

\begin{tabular}{|c|c|c||}
\hline Waste Component ID" & $\begin{array}{c}\text { Plutonium } \\
\text { Concentration } \\
\text { (g Pu/l Matrix) }\end{array}$ & $\begin{array}{c}\text { Atom Density } \\
\text { (Atoms/barn-cm) }\end{array}$ \\
\hline Pu-239 & 6.72 & $2.3890-5$ \\
& 5.51 & $1.9588-5$ \\
& 4.64 & $1.6495-5$ \\
& 3.38 & $1.2016-5$ \\
C & 2.32 & $8.2476-5$ \\
H & 1.39 & $4.9414-6$ \\
O & 0.95 & $3.3772-6$ \\
\hline
\end{tabular}


Table A-15. Atom densities used to evaluate waste that is characterized as concrete $\left(2.37 \mathrm{~g} / \mathrm{cm}^{3}\right)$ with plutonium concentrations that exceed $37.5 \%$ of the calculated critical concentration.

\begin{tabular}{|c|c|c|}
\hline Waste Component $\mathrm{ID}^{\circ}$ & $\begin{array}{l}\text { Plutonium } \\
\text { Concentration } \\
\text { (g Pu/lb Matutx) }\end{array}$ & $\begin{array}{c}\text { Atom Density } \\
\text { (Atoms/bam-cm) }\end{array}$ \\
\hline Pu-239 & 1.13 & $1.4875-5$ \\
\hline H & .. & $1.4868-2$ \\
\hline C & - & $3.8140-3$ \\
\hline 0 & -- & $4.1519-2$ \\
\hline $\mathrm{Ca}$ & - & $1.1588-2$ \\
\hline $\mathrm{Si}$ & - & $6.0370-3$ \\
\hline$F_{\theta}$ & - & $1.9680-4$ \\
\hline Al & - & $7.3500-4$ \\
\hline $\mathrm{Na}$ & -- & $3.0400-4$ \\
\hline $\mathbf{M g}$ & - & $5.8700-4$ \\
\hline
\end{tabular}

Table A-16. Atom densities used to evaluate waste that is characterized as metal (Al; $2.70 \mathrm{~g} / \mathrm{cm}^{3}$ ) with plutonium concentrations that exceed $37.5 \%$ of the calculated critical concentration.

\begin{tabular}{|c|c|c|}
\hline Wasto Component ID & $\begin{array}{c}\text { Plutonlum } \\
\text { Concentration } \\
\text { (g Pu/b Matrix) }\end{array}$ & $\begin{array}{c}\text { Atom Density } \\
\text { (Atoma/bam-cm) }\end{array}$ \\
\hline Pu-239 & 3.44 & $5.1592-5$ \\
\hline Al & -- & $1.4260-2$ \\
\hline
\end{tabular}

SCALE Standard Composnion LIbrary ID used for KENO-V a calculations

Table A-17. Atom densities used to evaluate waste that is characterized as brick $\left(\mathrm{Al}_{2} \mathrm{O}_{3}\right.$; $3.965 \mathrm{~g} / \mathrm{cm}^{3}$ ) with plutonium concentrations that exceed $37.5 \%$ of the calculated critical concentration.

\begin{tabular}{|c|c|c||}
\hline Waste Component ID* & $\begin{array}{c}\text { Plutonium } \\
\text { Concentration } \\
\text { (g Pu/b Matrix) }\end{array}$ & $\begin{array}{c}\text { Atom Density } \\
\text { (Atome/barn-cm) }\end{array}$ \\
\hline Pu-239 & 0.95 & $2.0923-5$ \\
\hline Al & -- & $4.6844-2$ \\
O & -- & $7.0266-2$ \\
\hline
\end{tabular}


APPENDIX B:

TYPICAL SCAMP, CSAS, MCNP, KENO, AND COMBINE INPUT LISTINGS 


\section{SUMMARY OF INPUT LISTINGS IN APPENDIX B}

1. Table 1 Case 1 , SCAMP input using Hansen-Roach cross sections $\ldots \ldots \ldots \ldots \ldots$

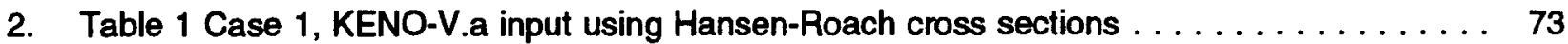

3. Table 1 Case 1, KENO-V.a input using CSAS and 27-group cross sections . . . . . . . . 74

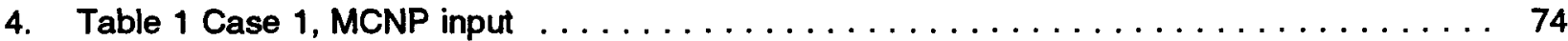

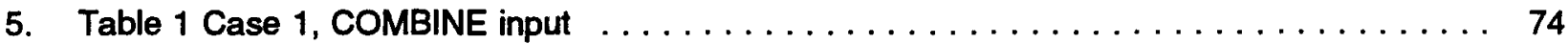

6. Table 1 Case 1, SCAMP input with COMBINE generated cross sections $\ldots \ldots \ldots \ldots \ldots$

7. Table 1 Case 2, SCAMP input using Hansen-Roach cross sections $\ldots \ldots \ldots \ldots \ldots \ldots$

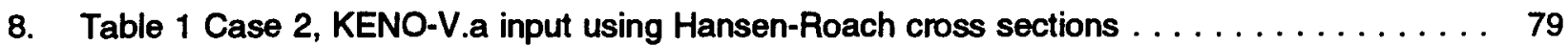

9. Table 1 Case 2, KENO-V.a input using CSAS and 27 -group cross sections $\ldots \ldots \ldots \ldots$

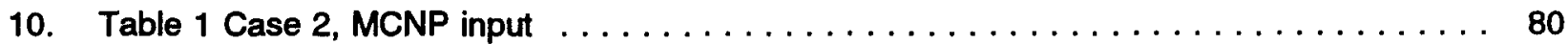

11. Table 1 Case 2, COMBINE input $\ldots \ldots \ldots \ldots \ldots \ldots \ldots \ldots \ldots \ldots \ldots \ldots \ldots \ldots$

12. Table 1 Case 2, SCAMP input with COMBINE generated cross sections $\ldots \ldots \ldots \ldots$

13. Table 1 Case 3, SCAMP input using Hansen-Roach cross sections $\ldots \ldots \ldots \ldots$

14. Table 1 Case 3, KENO-V.a input using Hansen-Roach cross sections . . . . . . . . . 86

15. Table 1 Case 3, KENO-V.a input using CSAS and 27 -group cross sections . . . . . . . 86

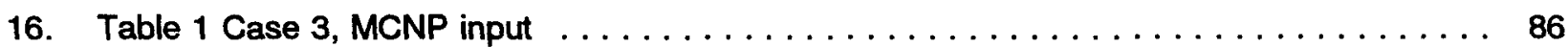

17. Table 1 Case 4, SCAMP input using Hansen-Roach cross sections $\ldots \ldots \ldots \ldots \ldots$

18. Table 1 Case 4, KENO-V.a input using Hansen-Roach cross sections $\ldots \ldots \ldots \ldots \ldots$

19. Table 1 Case 4, KENO-V.a input using CSAS and 27-group cross sections $\ldots \ldots \ldots 8$

20. Table 1 Case 4, MCNP input $\ldots \ldots \ldots \ldots \ldots \ldots \ldots \ldots \ldots \ldots \ldots \ldots \ldots$

21. Table 1 Case 5, SCAMP input using Hansen-Roach cross sections . . . . . . . . . . 89

22. Table 1 Case 5, KENO-V.a input using Hansen-Roach cross sections . . . . . . . . . . . 89

23. Table 1 Case 5, KENO-V.a input using CSAS and 27-group cross sections . . . . . . . . 90

24. Table 1 Case 5, MCNP input $\ldots \ldots \ldots \ldots \ldots \ldots \ldots \ldots \ldots \ldots \ldots \ldots \ldots$

25. Table 1 Case 6 , SCAMP input using Hansen-Roach cross sections $\ldots \ldots \ldots \ldots \ldots$

26. Table 1 Case 6, KENO-V.a input using Hansen-Roach cross sections . . . . . . . . . 91

27. Table 1 Case 6, KENO-V.a input using CSAS and 27-group cross sections . . . . . . . 92

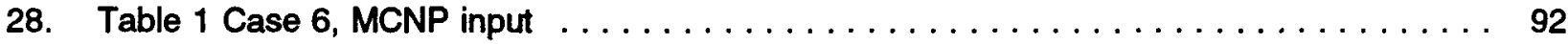

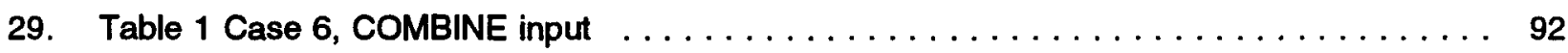

30. Table 1 Case 6, SCAMP input with COMBINE generated cross sections $\ldots \ldots \ldots \ldots \ldots$

31. Table 1 Case 7, SCAMP input using Hansen-Roach cross sections $\ldots \ldots \ldots \ldots \ldots$

32. Table 1 Case 7, KENO-V.a input using Hansen-Roach cross sections . . . . . . . . . . . . 97 
33. Table 1 Case 7, KENO-V.a input using CSAS and 27-group cross sections $\ldots \ldots \ldots . \ldots 9$

34. Table 1 Case 7 , MCNP input $\ldots \ldots \ldots \ldots \ldots \ldots \ldots \ldots \ldots \ldots \ldots \ldots \ldots \ldots \ldots \ldots \ldots \ldots$

35. Table 1 Case 7 , COMBINE input $\ldots \ldots \ldots \ldots \ldots \ldots \ldots \ldots \ldots \ldots \ldots$

36. Table 1 Case 7 , SCAMP input with COMBINE generated cross sections $\ldots \ldots \ldots \ldots$

37. Table 1 Case 9, SCAMP input using Hansen-Roach cross sections $\ldots \ldots \ldots \ldots \ldots 10 \ldots$

38. Table 1 Case 9, KENO-V.a input using Hansen-Roach cross sections . . . . . . . . . . 102

39. Table 1 Case 9, KENO-V.a input using CSAS and 27-group cross sections . . . . . . 102

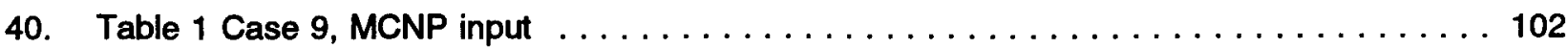

41. Table 5 Case 5, KENO-V.a input $\ldots \ldots \ldots \ldots \ldots \ldots \ldots \ldots \ldots \ldots \ldots \ldots \ldots \ldots \ldots \ldots$

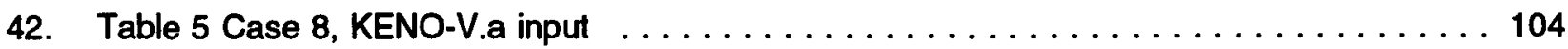

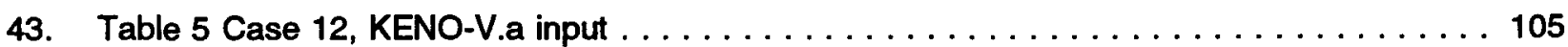

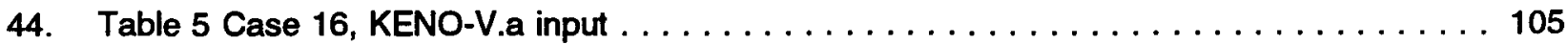

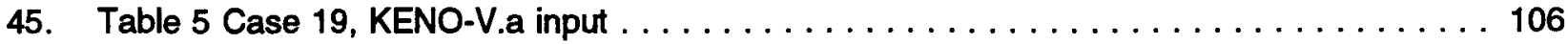

46. Table 6 Case 6 , KENO-V.a input $\ldots \ldots \ldots \ldots \ldots \ldots \ldots \ldots \ldots \ldots \ldots \ldots \ldots \ldots \ldots \ldots$

47. Table 9 Case 9,5 drums high KENO-V.a input $\ldots \ldots \ldots \ldots \ldots \ldots \ldots \ldots \ldots$

48. Table 9 Case 9 , fully infinite, KENO-V.a input $\ldots \ldots \ldots \ldots \ldots \ldots \ldots \ldots \ldots$

49. Table 9 Case 12,5 drums high, KENO-V.a input $\ldots \ldots \ldots \ldots \ldots \ldots \ldots \ldots$

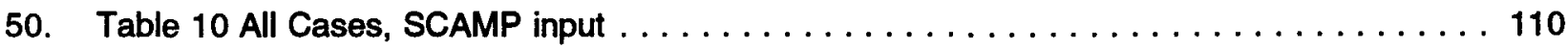

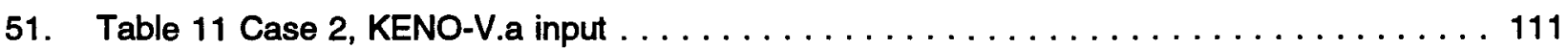

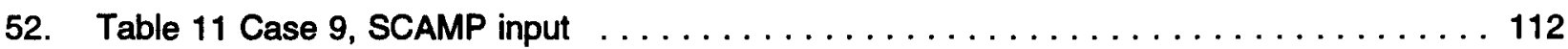

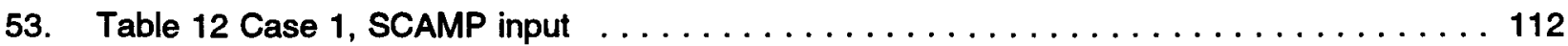

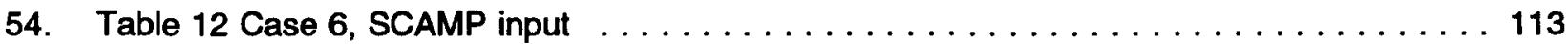

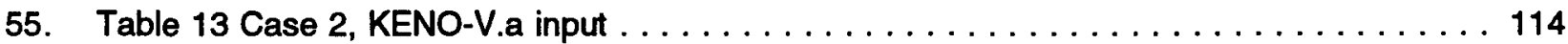

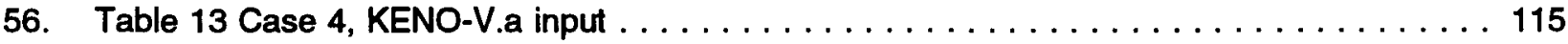

57. Table 14 Case $4 \mathrm{~b}$, Heavily loaded drums with $\mathrm{MgO}$ waste $\ldots \ldots \ldots \ldots \ldots \ldots \ldots$

58. Table 14 Case $4 c$, Heavily loaded drums with MgO waste. Double volume - half

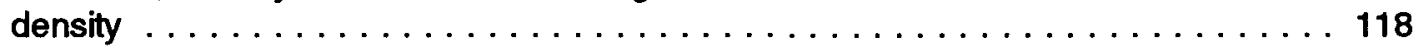

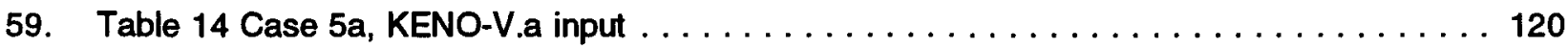

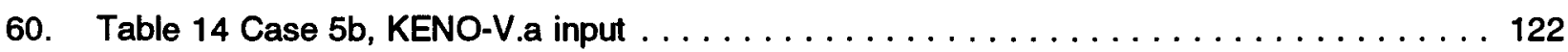

61. Table 14 Case 7, KENO-V.a input . . . . . . . . . . . . . . . . . . . . . . . 124 
Listing 1. Teble 1 case 1, scakp input using Hansen-Roach crose sections.

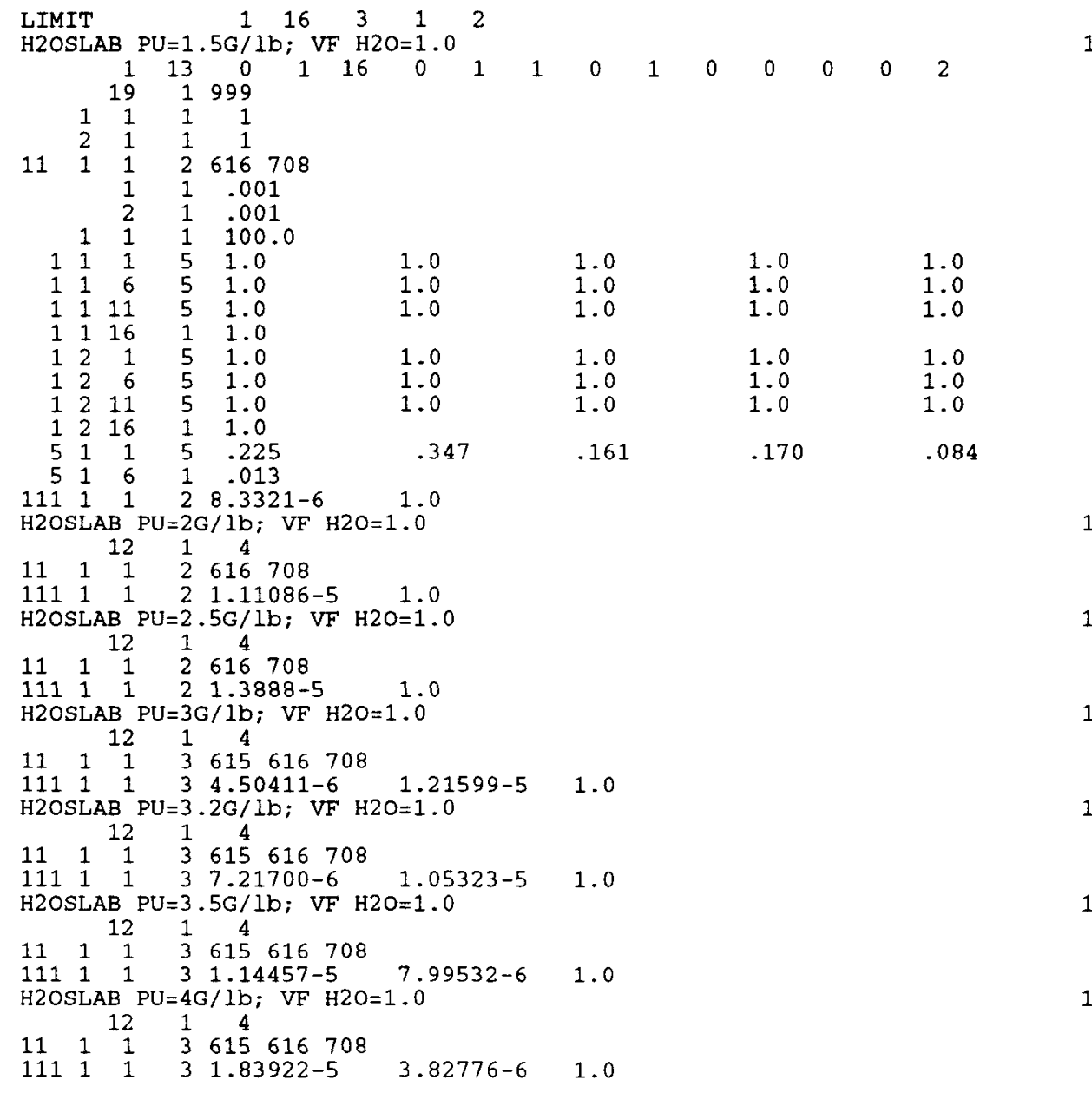

Listing 2. Table 1 Case 1, KENO-V.a Input using Bansen-Roach cross sections.

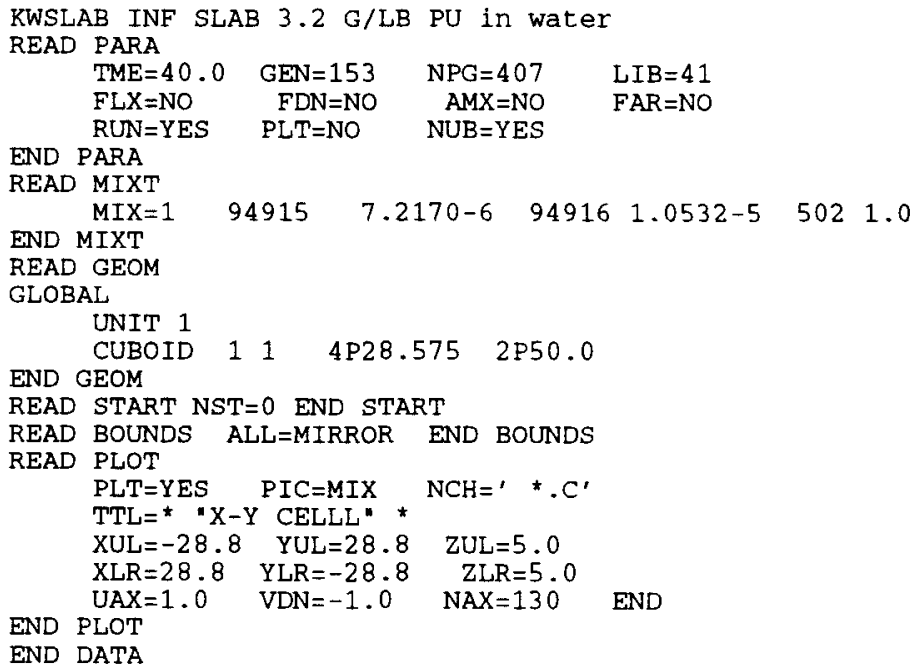


Lieting 3. Table 1 Case 1, Kiwo-v.a Input using csis and 27-group crose enctione.

$=\operatorname{CSAS} 25$

CWSLAB $3.2 \mathrm{~g} \mathrm{Pu} / \mathrm{lb}$ water

27GROUPNDF4 INFHOMMEDIUM

$\begin{array}{llllll}\mathrm{PU}-239 & 1 & 0 & 1.7777-5 & \text { END } \\ \mathrm{H} 2 \mathrm{O} & 1 & & 1.0 & \text { END }\end{array}$

END COMP

KWSLAB INF SLAB $3.2 \mathrm{G} / \mathrm{LB}$ PU in water

READ PARA

$\begin{array}{llll}\text { TME }=40.0 & \text { GEN }=153 & \text { NPG }=407 \\ \text { FLX }=\text { NO } & \text { FDN }=\text { NO } & \text { AMX }=\text { NO } & \text { FAR }=\text { NO }\end{array}$

END PARA

READ GEOM

GLOBAL

UNIT 1

END GEOM

CUBOID 1114 4P28.575 2P50.0

READ START NST=0 END START

READ BOUNDS ALL=MIRROR END BOUNDS

READ PLOT

PLT=YES PIC=MIX NCH='*. $\mathrm{C}^{\prime}$

TTL $=$ * $\mathrm{X}-\mathrm{Y}$ CELLL" *

$X U L=-28.8 \quad$ YUL $=28.8 \quad$ ZUL $=5.0$

$X L R=28.8 \quad Y L R=-28.8 \quad$ ZLR $=5.0$

END PLOT

$\mathrm{UAX}=1.0 \quad \mathrm{VDN}=-1.0 \quad \mathrm{NAX}=130 \quad$ END

END DATA

Listing 4. Table 1 Case 1, MCNP input.

MWSLAB INF SLAB 3.2 G/LB PU IN WATER

$111.00130749 e-1 \quad-1 \quad 2 \quad-3 \quad 4 \quad-5 \quad 6 \quad$ imp:n=1 \$slab

*1 px 28.575 \$asterisk means reflecting surface

$* 2 \quad \mathrm{px}-28.575$

*3 py 28.575

$* 4$ py -28.575

*5 pz 50.0

kcode $100012014550000 \quad \$ n p g=1000$, nsk=20 gen=145

sdef cel=1 \$starting source in cell 1

print

$\mathrm{m} 1 \quad 94239.50 \mathrm{c} \quad 1.7749 \mathrm{e}-5 \quad 1001.50 \mathrm{c} \quad 0.066742 \quad 8016.50 \mathrm{c} \quad 0.033371$

me1 lwtr.01t

Listing 5. Table 1 case 1, couBINB input.

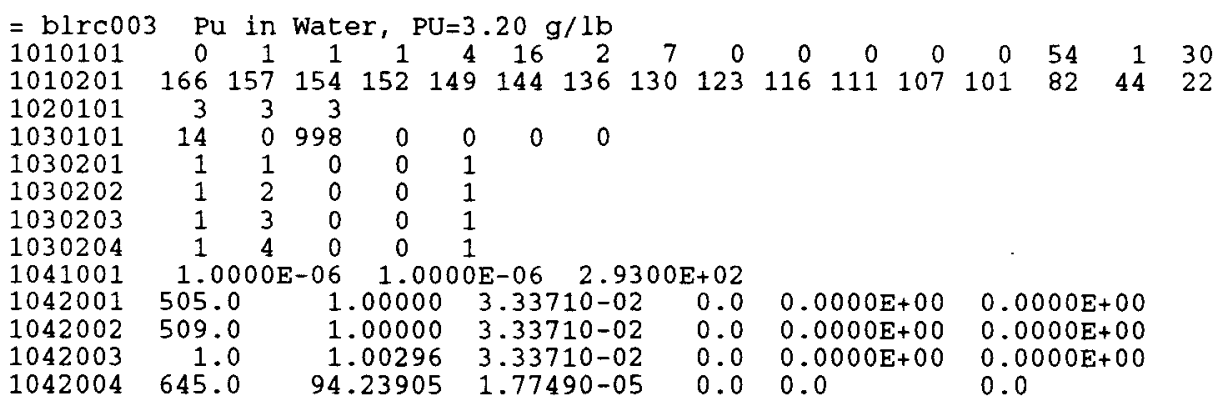


Table 1 case 1, scxup input with covBINE generated crose sectione.

LIMIT
ALCOM16

$\begin{array}{llllll}1 & 2.55974 \mathrm{E}-01 & 3.48185 \mathrm{E}-01 & 1.71622 \mathrm{E}-01 & 1.39795 \mathrm{E}-01 & 7.01995 \mathrm{E}-02\end{array}$ 5 1.34929E-02 $6.54148 \mathrm{E}-04 \quad 7.17970 \mathrm{E}-05 \quad 5.20614 \mathrm{E}-06 \quad 3.44291 \mathrm{E}-07$ $4 \quad 4.84487 \mathrm{E}-08$ 1.24487E-08 9.90516E-10 $3.69914 \mathrm{E}-10$

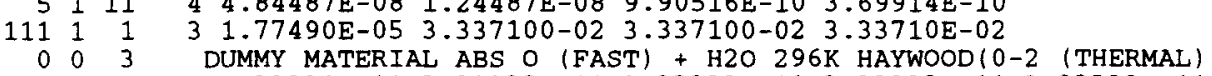

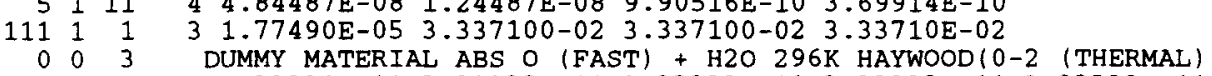

$\begin{array}{llllllllllllll}1 & 3 & 1 & 1 & 5 & 3.33330 \mathrm{E}+11 & 3.33332 \mathrm{E}+11 & 3.33333 \mathrm{E}+11 & 3.33333 \mathrm{E}+11 & 3.33333 \mathrm{E}+11 & 0 .\end{array}$

$\begin{array}{lllllllllllll}1 & 3 & 6 & 1 & 5 & 3.33333 E+11 & 3.33333 E+11 & 3.33333 E+11 & 3.33333 E+11 & 3.33333 E+11 & 0\end{array}$.

$\begin{array}{llllllllllll}1 & 3 & 11 & 1 & 5 & 3.33333 E+11 & 3.33333 E+11 & 3.33333 E+11 & 3.33333 E+11 & 8.72478 E-03 & 0 .\end{array}$

$\begin{array}{lllllllllll}1 & 3 & 16 & 1 & 1 & 4.42902 \mathrm{E}-03 & 0.00000 \mathrm{E}+00 & 0.00000 \mathrm{E}+00 & 0.00000 \mathrm{E}+00 & 0.00000 \mathrm{E}+00 & 0 .\end{array}$

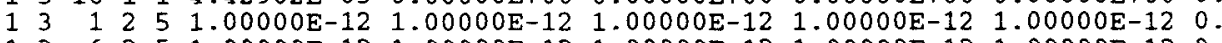

$1362251.00000 \mathrm{E}-12 \quad 1.00000 \mathrm{E}-12 \quad 1.00000 \mathrm{E}-12 \quad 1.00000 \mathrm{E}-12 \quad 1.00000 \mathrm{E}-120$.

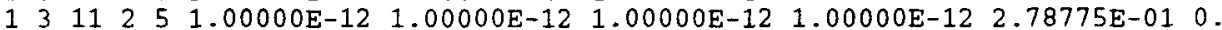

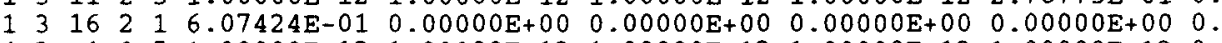

$4310051.00000 E-12 \quad 1.00000 E-12 \quad 1.00000 E-12 \quad 1.00000 E-12 \quad 1.00000 E-120$.

$436055 \quad 1.00000 \mathrm{E}-12 \quad 1.00000 \mathrm{E}-12 \quad 1.00000 \mathrm{E}-12 \quad 1.00000 \mathrm{E}-12 \quad 1.00000 \mathrm{E}-120$.

$43110551.00000 \mathrm{E}-12 \quad 1.00000 \mathrm{E}-12 \quad 1.00000 \mathrm{E}-12 \quad 1.00000 \mathrm{E}-12 \quad 4.27452 \mathrm{E}+010$.

$\begin{array}{llllllllllll}4 & 3 & 16 & 0 & 1 & 8.17683 \mathrm{E}+01 & 0.00000 \mathrm{E}+00 & 0.00000 \mathrm{E}+00 & 0.00000 \mathrm{E}+00 & 0.00000 \mathrm{E}+00 & 0 .\end{array}$

$\begin{array}{llllllllll}3 & 3 & 1511 & 5 & 0.00000 \mathrm{E}+00 & 0.00000 \mathrm{E}+00 & 0.00000 \mathrm{E}+00 & 8.92852 \mathrm{E}-02 & 3.88013 \mathrm{E}+01 & 0 .\end{array}$

$\begin{array}{llllllllll}63 & 1511 & 5 & 0.00000 E+00 & 0.00000 E+00 & 0.00000 E+00 & 1.11441 E-01 & 2.01178 E+01 & 0 .\end{array}$

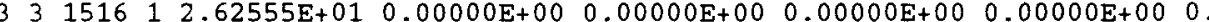

$\begin{array}{lllllllllll}6 & 3 & 1516 & 1 & 2.45044 \mathrm{E}+00 & 0.00000 \mathrm{E}+00 & 0.00000 \mathrm{E}+00 & 0.00000 \mathrm{E}+00 & 0.00000 \mathrm{E}+00 & 0 .\end{array}$

$\begin{array}{llllllllll}3 & 3 & 16115 & 0.00000 \mathrm{E}+00 & 0.00000 \mathrm{E}+00 & 0.00000 \mathrm{E}+00 & 9.30068 \mathrm{E}-06 & 3.59579 \mathrm{E}+00 & 0 .\end{array}$

$\begin{array}{lllllllll}6 & 3 & 1611 & 5 & 0.00000 \mathrm{E}+00 & 0.00000 \mathrm{E}+00 & 0.00000 \mathrm{E}+00-4.19115 \mathrm{E}-07 & 7.65132 \mathrm{E}-01 & 0\end{array}$

$\begin{array}{lllllllllll}3 & 3 & 1616 & 1 & 9.71905 \mathrm{E}+01 & 0.00000 \mathrm{E}+00 & 0.00000 \mathrm{E}+00 & 0.00000 \mathrm{E}+00 & 0.00000 \mathrm{E}+00 & 0\end{array}$

$\begin{array}{llllllllll}163 & 3 & 1616 & 1 & 1.88603 E+01 & 0.00000 E+00 & 0.00000 E+00 & 0.00000 E+00 & 0.00000 E+00 & 0 .\end{array}$ $0 \begin{array}{llll}0 & 0 & 1 & \text { OXYGEN-16 VERS } 5 \text { (FAST) + DUMMY MATERIAL ABS O (THERMAL) }\end{array}$

$\begin{array}{lllllllllll}1 & 1 & 1 & 1 & 5 & 2.70218 \mathrm{E}-01 & 2.34943 \mathrm{E}-01 & 9.30830 \mathrm{E}-02 & 9.44555 \mathrm{E}-02 & 7.58272 \mathrm{E}-02 & 0 .\end{array}$

$116 \begin{array}{llllllll}1 & 1 & 9.09870 \mathrm{E}-02 & 9.27106 \mathrm{E}-02 & 9.27186 \mathrm{E}-02 & 9.27794 \mathrm{E}-02 & 9.29676 \mathrm{E}-02 & 0 .\end{array}$

$\begin{array}{lllllllllll}1 & 1 & 11 & 1 & 5 & 9.26010 \mathrm{E}-02 & 9.28234 \mathrm{E}-02 & 9.28184 \mathrm{E}-02 & 9.27569 \mathrm{E}-02 & 3.33333 \mathrm{E}+06 & 0 .\end{array}$

$\begin{array}{llllllllllll}1 & 1 & 16 & 1 & 1 & 3.33333 \mathrm{E}+06 & 0.00000 \mathrm{E}+00 & 0.00000 \mathrm{E}+00 & 0.00000 \mathrm{E}+00 & 0.00000 \mathrm{E}+00 & 0 .\end{array}$

$\begin{array}{lllllllllll}1 & 1 & 1 & 2 & 5 & 4.15622 \mathrm{E}-02 & 2.19921 \mathrm{E}-08 & 2.76998 \mathrm{E}-08 & 3.71206 \mathrm{E}-08 & 6.11484 \mathrm{E}-08 & 0 .\end{array}$

$\begin{array}{lllllllllll}1 & 1 & 6 & 2 & 5 & 1.41066 \mathrm{E}-07 & 3.42413 \mathrm{E}-07 & 7.80394 \mathrm{E}-07 & 1.87374 \mathrm{E}-06 & 3.90670 \mathrm{E}-06 & 0 .\end{array}$

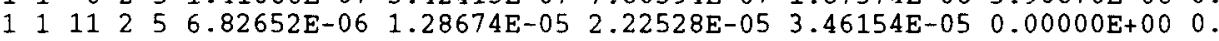

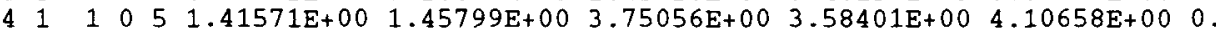

$416 \begin{array}{lllllllll}4 & 6 & 5 & 3.58611 E+00 & 3.57567 E+00 & 3.58742 E+00 & 3.58987 E+00 & 3.59042 E+00 & 0 .\end{array}$

$\begin{array}{lllllllllll}4 & 1 & 11 & 0 & 5 & 3.59052 \mathrm{E}+00 & 3.59052 \mathrm{E}+00 & 3.59053 \mathrm{E}+00 & 3.59057 \mathrm{E}+00 & 1.00000 \mathrm{E}-07 & 0 .\end{array}$

$\begin{array}{llllllllllll}4 & 1 & 16 & 0 & 1 & 1.00000 \mathrm{E}-07 & 0.00000 \mathrm{E}+00 & 0.00000 \mathrm{E}+00 & 0.00000 \mathrm{E}+00 & 0.00000 \mathrm{E}+00 & 0 .\end{array}$

$\begin{array}{lllllllllll}3 & 1 & 1 & 1 & 5 & 1.55783 \mathrm{E}+00 & 3.13866 \mathrm{E}-01 & 4.31109 \mathrm{E}-03 & 3.55220 \mathrm{E}-03 & 1.19044 \mathrm{E}-03 & 0 .\end{array}$

$6111150.17257 \mathrm{E}-01-1.11198 \mathrm{E}-01$ 8.20143E-04-2.89399E-05-2.02343E-04 0 .

$311 \quad 1 \quad 6 \quad 5 \quad 3.54884 \mathrm{E}-05 \quad 0.00000 \mathrm{E}+00 \quad 0.00000 \mathrm{E}+00 \quad 0.00000 \mathrm{E}+000.00000 \mathrm{E}+000$.

$\begin{array}{llllllllll}6 & 1 & 1 & 6 & 5-1.45122 \mathrm{E}-05 & 0.00000 \mathrm{E}+00 & 0.00000 \mathrm{E}+00 & 0.00000 \mathrm{E}+00 & 0.00000 \mathrm{E}+00 & 0\end{array}$

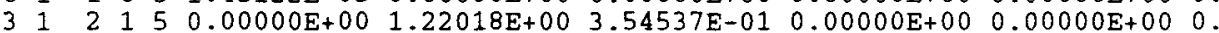

$\begin{array}{llllllllll}6 & 1 & 2 & 1 & 5 & 0.00000 \mathrm{E}+00 & 2.18719 \mathrm{E}-01-1.01992 \mathrm{E}-01 & 0.00000 \mathrm{E}+00 & 0.00000 \mathrm{E}+00 & 0 .\end{array}$

$31131550.00000 \mathrm{E}+00 \quad 0.00000 \mathrm{E}+00 \quad 2.81272 \mathrm{E}+00 \quad 1.04906 \mathrm{E}+00 \quad 0.00000 \mathrm{E}+000$.

$\begin{array}{lllllllllll}6 & 1 & 3 & 1 & 5 & 0.00000 \mathrm{E}+00 & 0.00000 \mathrm{E}+00 & 5.07782 \mathrm{E}-01-3.96553 \mathrm{E}-01 & 0.00000 \mathrm{E}+00 & 0 .\end{array}$

$\begin{array}{lllllllllll}3 & 1 & 4 & 1 & 5 & 0.00000 \mathrm{E}+00 & 0.00000 \mathrm{E}+00 & 0.00000 \mathrm{E}+00 & 3.57594 \mathrm{E}+00 & 8.35280 \mathrm{E}-01 & 0 .\end{array}$

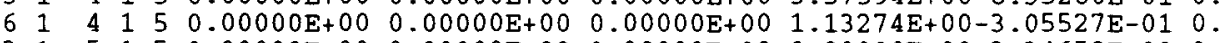

$\begin{array}{lllllllllll}3 & 1 & 5 & 1 & 5 & 0.00000 \mathrm{E}+00 & 0.00000 \mathrm{E}+00 & 0.00000 \mathrm{E}+00 & 0.00000 \mathrm{E}+00 & 3.34658 \mathrm{E}+00 & 0 .\end{array}$

$61151550.00000 \mathrm{E}+00 \quad 0.00000 \mathrm{E}+00 \quad 0.00000 \mathrm{E}+00 \quad 0.00000 \mathrm{E}+00-3.78529 \mathrm{E}-010$.

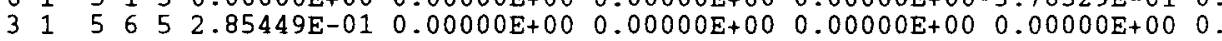

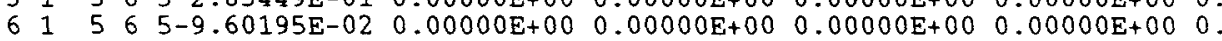

$\begin{array}{llllllllllll}3 & 1 & 6 & 6 & 5 & 3.46328 \mathrm{E}+00 & 1.91393 \mathrm{E}-01 & 0.00000 \mathrm{E}+00 & 0.00000 \mathrm{E}+00 & 0.00000 \mathrm{E}+00 & 0 .\end{array}$

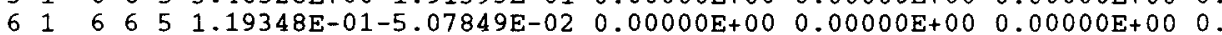

$3 \quad 1 \quad 7 \quad 6 \quad 550.00000 \mathrm{E}+00 \quad 3.43893 \mathrm{E}+00 \quad 2.93641 \mathrm{E}-01 \quad 0.00000 \mathrm{E}+00 \quad 0.00000 \mathrm{E}+00 \quad 0$.

$\begin{array}{llllllllll}6 & 1 & 7 & 6 & 5 & 0.00000 \mathrm{E}+00 & 2.41985 \mathrm{E}-01-8.50785 \mathrm{E}-02 & 0.00000 \mathrm{E}+00 & 0.00000 \mathrm{E}+00 & 0.0\end{array}$

$31886550.00000 \mathrm{E}+00 \quad 0.00000 \mathrm{E}+00 \quad 3.48804 \mathrm{E}+00 \quad 2.56804 \mathrm{E}-01 \quad 0.00000 \mathrm{E}+00 \quad 0$.

$\begin{array}{lllllllllll}6 & 1 & 8 & 6 & 5 & 0.00000 \mathrm{E}+00 & 0.00000 \mathrm{E}+00 & 2.33661 \mathrm{E}-01-7.62301 \mathrm{E}-02 & 0.00000 \mathrm{E}+00 & 0 .\end{array}$

$3199650.00000 \mathrm{E}+00 \quad 0.00000 \mathrm{E}+00 \quad 0.00000 \mathrm{E}+00 \quad 3.48941 \mathrm{E}+00 \quad 2.57998 \mathrm{E}-010$. 
Listing 6 . Continued.

$\begin{array}{lllllllll}6 & 1 & 6 & 5 & 0.00000 \mathrm{E}+00 & 0.00000 \mathrm{E}+00 & 0.00000 \mathrm{E}+00 & 2.35431 \mathrm{E}-01-7.78913 \mathrm{E}-02 & 0 .\end{array}$

$\begin{array}{lllllllllll}3 & 1 & 10 & 6 & 5 & 0.00000 \mathrm{E}+00 & 0.00000 \mathrm{E}+00 & 0.00000 \mathrm{E}+00 & 0.00000 \mathrm{E}+00 & 3.34503 \mathrm{E}+00 & 0 .\end{array}$

$\begin{array}{lllllllllllll}6 & 1 & 10 & 6 & 5 & 0.00000 \mathrm{E}+00 & 0.00000 \mathrm{E}+00 & 0.00000 \mathrm{E}+00 & 0.00000 \mathrm{E}+00 & 2.74157 \mathrm{E}-010 & 0 .\end{array}$

$\begin{array}{llllllllll}3 & 1 & 1011 & 5 & 4.02942 \mathrm{E}-01 & 0.00000 \mathrm{E}+00 & 0.00000 \mathrm{E}+00 & 0.00000 \mathrm{E}+00 & 0.00000 \mathrm{E}+00 & 0 .\end{array}$ $\begin{array}{lllllllll}6 & 1 & 1011 & 5-1.16593 \mathrm{E}-01 & 0.00000 \mathrm{E}+00 & 0.00000 \mathrm{E}+00 & 0.00000 \mathrm{E}+00 & 0.00000 \mathrm{E}+00 & 0 .\end{array}$

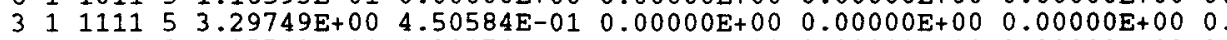
$\begin{array}{llllllllll}6 & 1 & 1111 & 5 & 2.95743 \mathrm{E}-01-1.38174 \mathrm{E}-01 & 0.00000 \mathrm{E}+00 & 0.00000 \mathrm{E}+00 & 0.00000 \mathrm{E}+00 & 0 .\end{array}$

$\begin{array}{llllllllll}3 & 1 & 1211 & 5 & 0.00000 E+00 & 3.44763 E+00 & 3.00449 E-01 & 0.00000 E+00 & 0.00000 E+00 & 0 .\end{array}$

$\begin{array}{lllllllll}6 & 1 & 1211 & 5 & 0.00000 \mathrm{E}+00 & 2.48892 \mathrm{E}-01-9.13235 \mathrm{E}-02 & 0.00000 \mathrm{E}+00 & 0.00000 \mathrm{E}+00 & 0 .\end{array}$

$\begin{array}{llllllllll}3 & 1 & 1311 & 5 & 0.00000 \mathrm{E}+00 & 0.00000 \mathrm{E}+00 & 3.14444 \mathrm{E}+00 & 6.03634 \mathrm{E}-01 & 0.00000 \mathrm{E}+00 & 0 .\end{array}$

$\begin{array}{llllllllll}6 & 1 & 1311 & 5 & 0.00000 \mathrm{E}+00 & 0.00000 \mathrm{E}+00 & 3.41418 \mathrm{E}-01-1.83849 \mathrm{E}-01 & 0.00000 \mathrm{E}+00 & 0\end{array}$

$3114115 \quad 0.00000 \mathrm{E}+00 \quad 0.00000 \mathrm{E}+00 \quad 0.00000 \mathrm{E}+00 \quad 3.29121 \mathrm{E}+00 \quad 4.56890 \mathrm{E}-010$.

$61141150.00000 \mathrm{E}+00 \quad 0.00000 \mathrm{E}+00 \quad 0.00000 \mathrm{E}+00 \quad 2.93675 \mathrm{E}-01-1.36106 \mathrm{E}-010$.

$\begin{array}{lllllllllll}16 & 1 & 1616 & 1 & 0.00000 \mathrm{E}+00 & 0.00000 \mathrm{E}+00 & 0.00000 \mathrm{E}+00 & 0.00000 \mathrm{E}+00 & 0.00000 \mathrm{E}+00 & 0\end{array}$

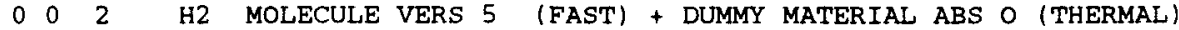

$\begin{array}{llllllllllll}1 & 2 & 1 & 1 & 5 & 1.24447 \mathrm{E}-01 & 9.88194 \mathrm{E}-02 & 1.16788 \mathrm{E}-01 & 9.43891 \mathrm{E}-02 & 7.17987 \mathrm{E}-02 & 0\end{array}$

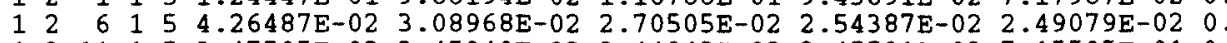

$12111552.47505 \mathrm{E}-02 \quad 2.45940 \mathrm{E}-02 \quad 2.44842 \mathrm{E}-02 \quad 2.45591 \mathrm{E}-02-7.15505 \mathrm{E}-010$.

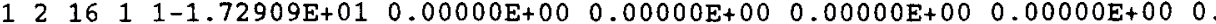

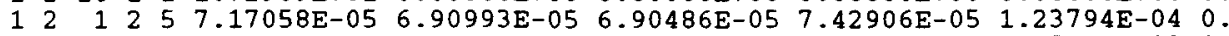

$126 \begin{array}{llllllll}1 & 5 & 4.12788 \mathrm{E}-04 & 1.23471 \mathrm{E}-03 & 2.91047 \mathrm{E}-03 & 6.97159 \mathrm{E}-03 & 1.45644 \mathrm{E}-02 & 0 .\end{array}$

$\begin{array}{lllllllllll}1 & 2 & 11 & 2 & 5 & 2.54520 \mathrm{E}-02 & 4.79799 \mathrm{E}-02 & 8.29830 \mathrm{E}-02 & 1.29094 \mathrm{E}-01 & 0.00000 \mathrm{E}+00 & 0\end{array}$

$4210051.31019 \mathrm{E}+00 \quad 2.00276 \mathrm{E}+00 \quad 2.80474 \mathrm{E}+00 \quad 3.80651 \mathrm{E}+00 \quad 6.25482 \mathrm{E}+000$.

$4260501.07080 \mathrm{E}+01 \quad 1.29825 \mathrm{E}+01 \quad 1.34840 \mathrm{E}+01 \quad 1.36010 \mathrm{E}+01 \quad 1.36246 \mathrm{E}+010$.

$42110051.36355 E+01 \quad 1.36579 E+01 \quad 1.36929 E+01 \quad 1.37391 E+01 \quad 1.00000 E-07 \quad 0$.

$\begin{array}{llllllllllll}4 & 2 & 16 & 0 & 1 & 1.00000 E-07 & 0.00000 E+00 & 0.00000 E+00 & 0.00000 E+00 & 0.00000 E+00 & 0\end{array}$

$\begin{array}{lllllllllll}3 & 2 & 1 & 1 & 5 & 9.68949 \mathrm{E}-01 & 1.43353 \mathrm{E}+00 & 5.08513 \mathrm{E}-01 & 4.14959 \mathrm{E}-01 & 2.65715 \mathrm{E}-01 & 0 .\end{array}$.

$\begin{array}{lllllllllll}6 & 2 & 1 & 1 & 5 & 9.11626 \mathrm{E}-01 & 9.93432 \mathrm{E}-01 & 2.53992 \mathrm{E}-01 & 1.54259 \mathrm{E}-01 & 6.31976 \mathrm{E}-02 & 0 .\end{array}$

$\begin{array}{lllllllllll}3 & 2 & 1 & 6 & 5 & 9.23779 \mathrm{E}-02 & 1.12368 \mathrm{E}-02 & 2.66670 \mathrm{E}-03 & 4.63407 \mathrm{E}-04 & 6.95409 \mathrm{E}-05 & 0\end{array}$

$\begin{array}{llllllllllll}6 & 2 & 1 & 6 & 5 & 1.11319 \mathrm{E}-02 & 6.03812 \mathrm{E}-04 & 1.05844 \mathrm{E}-04 & 2.50283 \mathrm{E}-05 & 7.24633 \mathrm{E}-06 & 0 .\end{array}$

$\begin{array}{llllllllll}32 & 111 & 5 & 1.76515 \mathrm{E}-05 & 7.98059 \mathrm{E}-06 & 1.20373 \mathrm{E}-06 & 4.41833 \mathrm{E}-07 & 0.00000 \mathrm{E}+00 & 0 .\end{array}$

$\begin{array}{llllllllll}62 & 111 & 5 & 3.20090 \mathrm{E}-06 & 2.58264 \mathrm{E}-06 & 7.12684 \mathrm{E}-07 & 3.36318 \mathrm{E}-07 & 0.00000 \mathrm{E}+00 & 0\end{array}$

$\begin{array}{llllllllllll}32 & 2 & 1 & 5 & 0.00000 \mathrm{E}+00 & 1.66048 \mathrm{E}+00 & 1.66642 \mathrm{E}+00 & 1.35810 \mathrm{E}+00 & 8.68778 \mathrm{E}-01 & 0\end{array}$

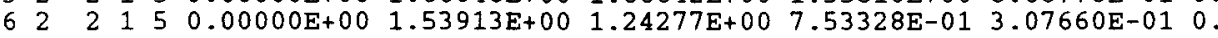

$\begin{array}{lllllllllll}32 & 2 & 6 & 5 & 3.01888 \mathrm{E}-01 & 3.62610 \mathrm{E}-02 & 8.56225 \mathrm{E}-03 & 1.48791 \mathrm{E}-03 & 2.23281 \mathrm{E}-04 & 0 .\end{array}$

$\begin{array}{lllllllllll}6 & 2 & 2 & 6 & 5 & 5.35607 \mathrm{E}-02 & 2.67123 \mathrm{E}-03 & 3.82522 \mathrm{E}-04 & 6.79706 \mathrm{E}-05 & 1.74610 \mathrm{E}-05 & 0\end{array}$

$\begin{array}{llllllllll}3 & 2 & 211 & 5 & 5.66753 \mathrm{E}-05 & 2.56240 \mathrm{E}-05 & 3.88320 \mathrm{E}-06 & 2.18342 \mathrm{E}-06 & 2.12144 \mathrm{E}-07 & 0 .\end{array}$

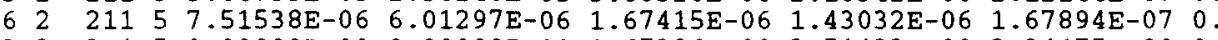

$\begin{array}{lllllllllll}32 & 3 & 1 & 5 & 0.00000 \mathrm{E}+00 & 0.00000 \mathrm{E}+00 & 1.67386 \mathrm{E}+00 & 3.51423 \mathrm{E}+00 & 2.24475 \mathrm{E}+00 & 0\end{array}$

$\begin{array}{llllllllllll}6 & 2 & 3 & 1 & 5 & 0.00000 E+00 & 0.00000 E+00 & 1.61026 E+00 & 2.64305 E+00 & 1.07689 E+00 & 0\end{array}$

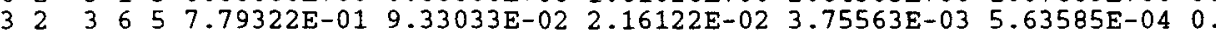

$\begin{array}{lllllllllll}6 & 2 & 3 & 6 & 5 & 1.86414 \mathrm{E}-01 & 8.98541 \mathrm{E}-03 & 1.12755 \mathrm{E}-03 & 1.57070 \mathrm{E}-04 & 3.46667 \mathrm{E}-05 & 0 .\end{array}$

$\begin{array}{llllllllll}3 & 2 & 3115 & 1.43054 \mathrm{E}-04 & 6.46777 \mathrm{E}-05 & 9.80159 \mathrm{E}-06 & 5.54681 \mathrm{E}-06 & 1.92242 \mathrm{E}-06 & 0\end{array}$

623115 1.43502E-05 $1.13309 \mathrm{E}-05 \quad 3.14063 \mathrm{E}-06 \quad 2.70981 \mathrm{E}-06 \quad 1.47596 \mathrm{E}-06 \quad 0$.

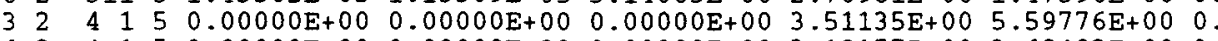

$\begin{array}{llllllllllll}6 & 2 & 4 & 1 & 5 & 0.00000 \mathrm{E}+00 & 0.00000 \mathrm{E}+00 & 0.00000 \mathrm{E}+00 & 3.19157 \mathrm{E}+00 & 3.68482 \mathrm{E}+00 & 0 .\end{array}$

$325466501.94357 \mathrm{E}+00 \quad 2.35581 \mathrm{E}-01 \quad 5.39107 \mathrm{E}-02 \quad 9.36827 \mathrm{E}-03 \quad 1.40584 \mathrm{E}-03 \quad 0$.

$\begin{array}{lllllllllll}6 & 2 & 4 & 6 & 5 & 6.36204 \mathrm{E}-01 & 3.04327 \mathrm{E}-02 & 3.51650 \mathrm{E}-03 & 3.93821 \mathrm{E}-04 & 7.08352 \mathrm{E}-05 & 0\end{array}$

$\begin{array}{llllllllll}3 & 2 & 411 & 5 & 3.56843 \mathrm{E}-04 & 1.61336 \mathrm{E}-04 & 2.44497 \mathrm{E}-05 & 1.38363 \mathrm{E}-05 & 6.41613 \mathrm{E}-06 & 0 .\end{array}$

$\begin{array}{llllllllll}6 & 2 & 411 & 5 & 2.74424 \mathrm{E}-05 & 2.11528 \mathrm{E}-05 & 5.81384 \mathrm{E}-06 & 5.00664 \mathrm{E}-06 & 4.08893 \mathrm{E}-06 & 0\end{array}$

$\begin{array}{lllllllllll}3 & 2 & 416 & 1 & 3.01382 \mathrm{E}-09 & 0.00000 \mathrm{E}+00 & 0.00000 \mathrm{E}+00 & 0.00000 \mathrm{E}+00 & 0.00000 \mathrm{E}+00 & 0 .\end{array}$

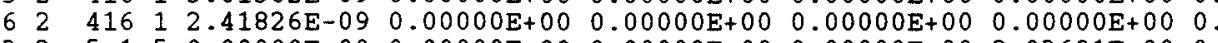

$\begin{array}{llllllllll}32 & 5 & 1 & 0.00000 \mathrm{E}+00 & 0.00000 \mathrm{E}+00 & 0.00000 \mathrm{E}+00 & 0.00000 \mathrm{E}+00 & 8.03691 \mathrm{E}+00 & 0\end{array}$

$\begin{array}{lllllllllll}6 & 2 & 5 & 1 & 5 & 0.00000 \mathrm{E}+00 & 0.00000 \mathrm{E}+00 & 0.00000 \mathrm{E}+00 & 0.00000 \mathrm{E}+00 & 6.90970 \mathrm{E}+00 & 0\end{array}$

$\begin{array}{lllllllllll}3 & 2 & 5 & 6 & 5 & 9.12591 \mathrm{E}+00 & 1.10965 \mathrm{E}+00 & 2.59966 \mathrm{E}-01 & 4.39893 \mathrm{E}-02 & 6.60121 \mathrm{E}-03 & 0 .\end{array}$

$\begin{array}{lllllllllll}6 & 2 & 5 & 6 & 5 & 5.14815 \mathrm{E}+00 & 2.43168 \mathrm{E}-01 & 2.72066 \mathrm{E}-02 & 2.28952 \mathrm{E}-03 & 2.73762 \mathrm{E}-04 & 0 .\end{array}$

$\begin{array}{llllllllll}3 & 2 & 511 & 5 & 1.67558 \mathrm{E}-03 & 7.57562 \mathrm{E}-04 & 1.14805 \mathrm{E}-04 & 6.49692 \mathrm{E}-05 & 3.11059 \mathrm{E}-05 & 0 .\end{array}$

$\begin{array}{llllllllll}62 & 511 & 5 & 8.62624 \mathrm{E}-05 & 6.06892 \mathrm{E}-05 & 1.61138 \mathrm{E}-05 & 1.37640 \mathrm{E}-05 & 1.21716 \mathrm{E}-05 & 0 .\end{array}$

$\begin{array}{lllllllll}32 & 516 & 1 & 5.02173 \mathrm{E}-06 & 0.00000 \mathrm{E}+00 & 0.00000 \mathrm{E}+00 & 0.00000 \mathrm{E}+00 & 0.00000 \mathrm{E}+00 & 0 .\end{array}$

$\begin{array}{lllllllllll}62 & 516 & 1 & 3.31150 \mathrm{E}-06 & 0.00000 E+00 & 0.00000 E+00 & 0.00000 E+00 & 0.00000 E+00 & 0\end{array}$

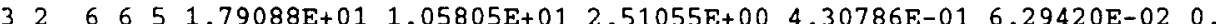

$\begin{array}{lllllllllll}6 & 2 & 6 & 6 & 5 & 1.46354 \mathrm{E}+01 & 5.51971 \mathrm{E}+00 & 6.06656 \mathrm{E}-01 & 4.50233 \mathrm{E}-02 & 3.35348 \mathrm{E}-03 & 0 .\end{array}$

$\begin{array}{llllllllll}3 & 2 & 611 & 5 & 1.59765 \mathrm{E}-02 & 7.22329 \mathrm{E}-03 & 1.09466 \mathrm{E}-03 & 6.19475 \mathrm{E}-04 & 2.86404 \mathrm{E}-04 & 0 .\end{array}$

$62 \quad 61156.55205 \mathrm{E}-04 \quad 3.16282 \mathrm{E}-04 \quad 6.84986 \mathrm{E}-05 \quad 5.53256 \mathrm{E}-05 \quad 4.42407 \mathrm{E}-05 \quad 0$.

$\begin{array}{lllllllll}32 & 616 & 1 & 8.31915 \mathrm{E}-05 & 0.00000 \mathrm{E}+00 & 0.00000 \mathrm{E}+00 & 0.00000 \mathrm{E}+00 & 0.00000 \mathrm{E}+00 & 0 .\end{array}$

$\begin{array}{llllllllll}6 & 2 & 616 & 1 & 2.96623 \mathrm{E}-05 & 0.00000 \mathrm{E}+00 & 0.00000 \mathrm{E}+00 & 0.00000 \mathrm{E}+00 & 0.00000 \mathrm{E}+00 & 0.0\end{array}$

$\begin{array}{lllllllllll}32 & 7 & 6 & 5 & 0.00000 \mathrm{E}+00 & 1.87846 \mathrm{E}+01 & 1.66711 \mathrm{E}+01 & 2.89700 \mathrm{E}+00 & 4.29951 \mathrm{E}-01 & 0\end{array}$

$\begin{array}{lllllllllllll}6 & 2 & 7 & 6 & 5 & 0.00000 \mathrm{E}+00 & 1.58573 \mathrm{E}+01 & 9.37251 \mathrm{E}+00 & 6.83470 \mathrm{E}-01 & 4.62436 \mathrm{E}-02 & 0\end{array}$

$\begin{array}{llllllllll}3 & 2 & 711 & 5 & 1.06079 \mathrm{E}-01 & 4.79606 \mathrm{E}-02 & 7.26820 \mathrm{E}-03 & 4.11314 \mathrm{E}-03 & 1.89116 \mathrm{E}-03 & 0\end{array}$

$\begin{array}{lllllllllll}6 & 2 & 711 & 5 & 6.84526 \mathrm{E}-03 & 2.20126 \mathrm{E}-03 & 3.04741 \mathrm{E}-04 & 2.02762 \mathrm{E}-04 & 1.31832 \mathrm{E}-04 & 0 .\end{array}$

$\begin{array}{lllllllllll}3 & 2 & 716 & 1 & 5.92220 \mathrm{E}-04 & 0.00000 \mathrm{E}+00 & 0.00000 \mathrm{E}+00 & 0.00000 \mathrm{E}+00 & 0.00000 \mathrm{E}+00 & 0\end{array}$

$\begin{array}{lllllllllll}6 & 2 & 716 & 1 & 1.19092 \mathrm{E}-04 & 0.00000 \mathrm{E}+00 & 0.00000 \mathrm{E}+00 & 0.00000 \mathrm{E}+00 & 0.00000 \mathrm{E}+00 & 0 .\end{array}$

$\begin{array}{lllllllllll}3 & 2 & 8 & 6 & 5 & 0.00000 \mathrm{E}+00 & 0.00000 \mathrm{E}+00 & 2.13917 \mathrm{E}+01 & 1.57991 \mathrm{E}+01 & 2.37087 \mathrm{E}+00 & 0 .\end{array}$

$6286650.00000 \mathrm{E}+00 \quad 0.00000 \mathrm{E}+00 \quad 1.75952 \mathrm{E}+01 \quad 8.73622 \mathrm{E}+00 \quad 5.81100 \mathrm{E}-010$.

$\begin{array}{llllllllll}3 & 2 & 811 & 5 & 5.99837 \mathrm{E}-01 & 2.65069 \mathrm{E}-01 & 3.96378 \mathrm{E}-02 & 2.24314 \mathrm{E}-02 & 1.03008 \mathrm{E}-02 & 0 .\end{array}$

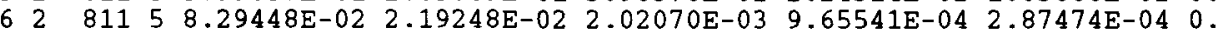


$\begin{array}{llllllllll}32 & 816 & 1 & 3.26412 \mathrm{E}-03 & 0.00000 \mathrm{E}+00 & 0.00000 \mathrm{E}+00 & 0.00000 \mathrm{E}+00 & 0.00000 \mathrm{E}+00 & 0 .\end{array}$

$\begin{array}{llllllllll}6 & 2 & 816 & 1 & 4.64616 \mathrm{E}-04 & 0.00000 E+00 & 0.00000 E+00 & 0.00000 E+00 & 0.00000 E+00 & 0 .\end{array}$

$\begin{array}{llllllllllll}32 & 9 & 6 & 5 & 0.00000 E+00 & 0.00000 E+00 & 0.00000 E+00 & 2.15778 E+01 & 1.37566 E+01 & 0 .\end{array}$

$\begin{array}{lllllllllllll}62 & 9 & 6 & 5 & 0.00000 \mathrm{E}+00 & 0.00000 \mathrm{E}+00 & 0.00000 \mathrm{E}+00 & 1.76733 \mathrm{E}+01 & 8.10452 \mathrm{E}+00 & 0\end{array}$

$\begin{array}{llllllllll}3 & 2 & 911 & 5 & 3.49181 \mathrm{E}+00 & 1.57765 \mathrm{E}+00 & 2.36008 \mathrm{E}-01 & 1.30644 \mathrm{E}-01 & 5.97691 \mathrm{E}-02 & 0\end{array}$

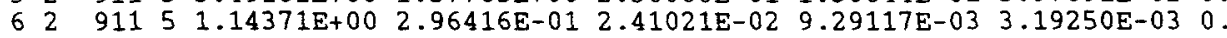

$\begin{array}{lllllllllll}3 & 2 & 916 & 1 & 1.89396 \mathrm{E}-02 & 0.00000 \mathrm{E}+00 & 0.00000 \mathrm{E}+00 & 0.00000 \mathrm{E}+00 & 0.00000 \mathrm{E}+00 & 0\end{array}$

$\begin{array}{llllllllll}62 & 916 & 1 & 6.98574 \mathrm{E}-04 & 0.00000 \mathrm{E}+00 & 0.00000 \mathrm{E}+00 & 0.00000 \mathrm{E}+00 & 0.00000 \mathrm{E}+00 & 0\end{array}$

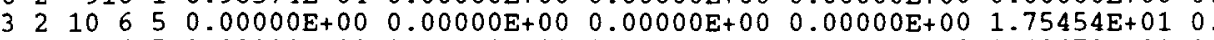

$\begin{array}{lllllllllllll}62 & 10 & 6 & 5 & 0.00000 E+00 & 0.00000 E+00 & 0.00000 E+00 & 0.00000 E+00 & 1.49479 E+01 & 0 .\end{array}$

$32101151.47638 \mathrm{E}+01 \quad 6.67436 \mathrm{E}+00 \quad 1.01100 \mathrm{E}+00 \quad 5.70617 \mathrm{E}-01 \quad 2.52667 \mathrm{E}-01 \quad 0$

$\begin{array}{lllllllll}6 & 2 & 10115 & 9.57736 \mathrm{E}+00 & 2.46620 \mathrm{E}+00 & 1.97745 \mathrm{E}-01 & 7.48229 \mathrm{E}-02 & 2.28535 \mathrm{E}-02 & 0 .\end{array}$

$\begin{array}{llllllllll}3 & 2 & 1016 & 1 & 8.00649 \mathrm{E}-02 & 0.00000 \mathrm{E}+00 & 0.00000 \mathrm{E}+00 & 0.00000 \mathrm{E}+00 & 0.00000 \mathrm{E}+00 & 0\end{array}$

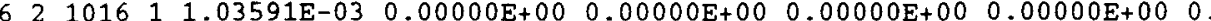

$\begin{array}{llllllllll}3 & 2 & 11115 & 5 & 1.49895 \mathrm{E}+01 & 2.01282 \mathrm{E}+01 & 3.05046 \mathrm{E}+00 & 1.72633 \mathrm{E}+00 & 7.62037 \mathrm{E}-01 & 0\end{array}$

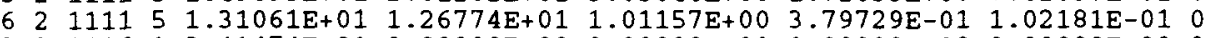

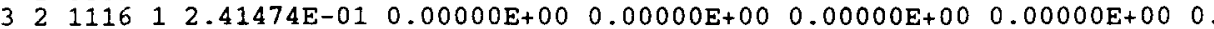

$\begin{array}{llllllllll}6 & 2 & 1116 & 1 & 1.09838 \mathrm{E}-02 & 0.00000 \mathrm{E}+00 & 0.00000 \mathrm{E}+00 & 0.00000 \mathrm{E}+00 & 0.00000 \mathrm{E}+00 & 0\end{array}$

$\begin{array}{lllllllllll}3 & 2 & 1211 & 5 & 0.00000 \mathrm{E}+00 & 1.98180 \mathrm{E}+01 & 1.11246 \mathrm{E}+01 & 6.29539 \mathrm{E}+00 & 2.77916 \mathrm{E}+00 & 0\end{array}$

$\begin{array}{lllllllll}62 & 1211 & 5 & 0.00000 \mathrm{E}+00 & 1.65046 \mathrm{E}+01 & 7.27408 \mathrm{E}+00 & 2.72017 \mathrm{E}+00 & 6.99623 \mathrm{E}-01 & 0\end{array}$

$\begin{array}{llllllllll}3 & 2 & 1216 & 1 & 8.80658 \mathrm{E}-01 & 0.00000 \mathrm{E}+00 & 0.00000 \mathrm{E}+00 & 0.00000 \mathrm{E}+00 & 0.00000 \mathrm{E}+00 & 0 .\end{array}$

$\begin{array}{llllllllll}6 & 2 & 1216 & 1 & 8.93846 \mathrm{E}-02 & 0.00000 \mathrm{E}+00 & 0.00000 \mathrm{E}+00 & 0.00000 \mathrm{E}+00 & 0.00000 \mathrm{E}+00 & 0\end{array}$

$\begin{array}{llllllllll}3 & 2 & 1311 & 5 & 0.00000 \mathrm{E}+00 & 0.00000 \mathrm{E}+00 & 1.21353 \mathrm{E}+01 & 1.81887 \mathrm{E}+01 & 8.02943 \mathrm{E}+00 & 0\end{array}$

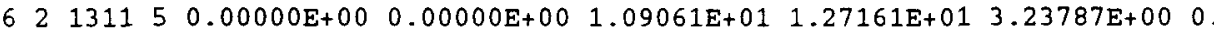

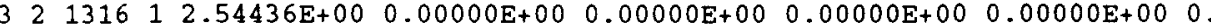

$\begin{array}{lllllllllll}6 & 2 & 1316 & 1 & 4.27689 \mathrm{E}-01 & 0.00000 \mathrm{E}+00 & 0.00000 \mathrm{E}+00 & 0.00000 \mathrm{E}+00 & 0.00000 \mathrm{E}+00 & 0\end{array}$

$\begin{array}{llllllllll}3 & 2 & 1411 & 5 & 0.00000 \mathrm{E}+00 & 0.00000 \mathrm{E}+00 & 0.00000 \mathrm{E}+00 & 1.50696 \mathrm{E}+01 & 1.96134 \mathrm{E}+01 & 0 .\end{array}$

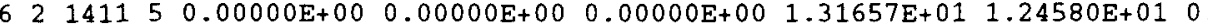

$\begin{array}{llllllllll}3 & 2 & 1416 & 1 & 6.21507 \mathrm{E}+00 & 0.00000 \mathrm{E}+00 & 0.00000 \mathrm{E}+00 & 0.00000 \mathrm{E}+00 & 0.00000 \mathrm{E}+00 & 0 .\end{array}$

$\begin{array}{llllllllll}6 & 2 & 1416 & 1 & 1.66426 \mathrm{E}+00 & 0.00000 \mathrm{E}+00 & 0.00000 \mathrm{E}+00 & 0.00000 \mathrm{E}+00 & 0.00000 \mathrm{E}+00 & 0 .\end{array}$

$\begin{array}{llllllllll}16 & 6 & 1616 & 1 & 0.00000 \mathrm{E}+00 & 0.00000 \mathrm{E}+00 & 0.00000 \mathrm{E}+00 & 0.00000 \mathrm{E}+00 & 0.00000 \mathrm{E}+00 & 0.00 .\end{array}$ $0 \begin{array}{llll}0 & 0 & \text { PLUTONIUM-239 VERS (FAST) + PLUTONIUM-239 VERS (THERMAL) }\end{array}$

$\begin{array}{lllllllllll}1 & 4 & 1 & 1 & 5 & 8.43880 \mathrm{E}-02 & 6.98059 \mathrm{E}-02 & 6.70189 \mathrm{E}-02 & 5.74955 \mathrm{E}-02 & 3.81951 \mathrm{E}-02 & 0\end{array}$

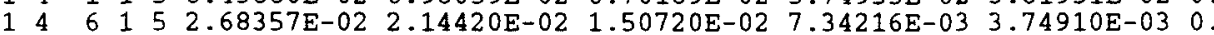

$14111552.08359 \mathrm{E}-03 \quad 6.80786 \mathrm{E}-03 \quad 8.94497 \mathrm{E}-03 \quad 1.72119 \mathrm{E}-03 \quad 2.36149 \mathrm{E}-04 \quad 0$.

$\begin{array}{lllllllllll}1 & 4 & 16 & 1 & 1 & 3.75804 E-04 & 0.00000 E+00 & 0.00000 E+00 & 0.00000 E+00 & 0.00000 E+00 & 0\end{array}$ $\begin{array}{lllllllllll}14 & 1 & 2 & 5 & 1.79071 E+00 & 1.93879 E+00 & 1.78961 E+00 & 1.70879 E+00 & 1.72597 E+00 & 0\end{array}$

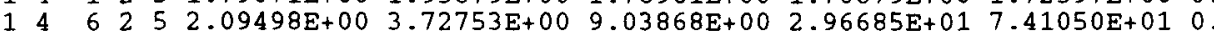
$\begin{array}{lllllllllll}14 & 11 & 2 & 5 & 1.48932 \mathrm{E}+02 & 4.02879 \mathrm{E}+01 & 2.74447 \mathrm{E}+01 & 1.82512 \mathrm{E}+02 & 1.20154 \mathrm{E}+03 & 0\end{array}$

$\begin{array}{llllllllll}14 & 16 & 2 & 1 & 9.65201 \mathrm{E}+02 & 0.00000 \mathrm{E}+00 & 0.00000 \mathrm{E}+00 & 0.00000 \mathrm{E}+00 & 0.00000 \mathrm{E}+00 & 0\end{array}$ $\begin{array}{llllllllllll}14 & 1 & 3 & 5 & 6.35191 \mathrm{E}+00 & 6.08752 \mathrm{E}+00 & 5.33621 \mathrm{E}+00 & 4.80538 \mathrm{E}+00 & 4.46522 \mathrm{E}+00 & 0\end{array}$ $1466356.72170 \mathrm{E}+00 \quad 6.48116 \mathrm{E}+00 \quad 1.37960 \mathrm{E}+01 \quad 4.44853 \mathrm{E}+01 \quad 1.10295 \mathrm{E}+020$. $\begin{array}{lllllllllll}1 & 4 & 11 & 3 & 5 & 2.55653 \mathrm{E}+02 & 7.28810 \mathrm{E}+01 & 6.13872 \mathrm{E}+01 & 3.55707 \mathrm{E}+02 & 2.15866 \mathrm{E}+03 & 0\end{array}$ $14163122.02429 \mathrm{E}+03 \quad 0.00000 \mathrm{E}+00 \quad 0.00000 \mathrm{E}+00 \quad 0.00000 \mathrm{E}+00 \quad 0.00000 \mathrm{E}+000$ $\begin{array}{lllllllllll}1 & 4 & 1 & 4 & 5 & 1.80634 \mathrm{E}+00 & 1.93025 \mathrm{E}+00 & 1.76436 \mathrm{E}+00 & 1.62250 \mathrm{E}+00 & 1.53452 \mathrm{E}+00 & 0 .\end{array}$

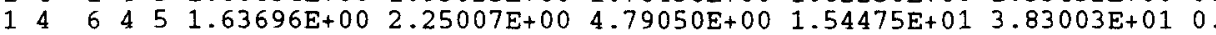
$\begin{array}{llllllllllll}1 & 4 & 11 & 4 & 5 & 8.87760 E+01 & 2.53081 E+01 & 2.13170 E+01 & 1.23520 E+02 & 7.46582 E+02 & 0\end{array}$ $1416417.00109 \mathrm{E}+02 \quad 0.00000 \mathrm{E}+00 \quad 0.00000 \mathrm{E}+00 \quad 0.00000 \mathrm{E}+00 \quad 0.00000 \mathrm{E}+000$ $\begin{array}{lllllllllll}4 & 4 & 1 & 0 & 5 & 4.01287 \mathrm{E}+00 & 4.75819 \mathrm{E}+00 & 4.98201 \mathrm{E}+00 & 5.82337 \mathrm{E}+00 & 8.76123 \mathrm{E}+00 & 0\end{array}$ $4460501.24684 \mathrm{E}+01 \quad 1.55826 \mathrm{E}+01 \quad 2.21729 \mathrm{E}+01 \quad 4.54481 \mathrm{E}+01 \quad 8.88504 \mathrm{E}+01 \quad 0$. $\begin{array}{llllllllllll}4 & 4 & 11 & 0 & 5 & 1.59972 E+02 & 4.88307 E+01 & 3.72701 E+01 & 1.93920 E+02 & 1.20933 E+03 & 0 .\end{array}$ $\begin{array}{lllllllllll}4 & 4 & 16 & 0 & 1 & 9.73058 \mathrm{E}+02 & 0.00000 \mathrm{E}+00 & 0.00000 \mathrm{E}+00 & 0.00000 \mathrm{E}+00 & 0.00000 \mathrm{E}+00 & 0 .\end{array}$ $\begin{array}{lllllllllll}3 & 4 & 1 & 1 & 5 & 4.78343 \mathrm{E}+00 & 2.53963 \mathrm{E}-01 & 2.85347 \mathrm{E}-01 & 3.63082 \mathrm{E}-01 & 2.06905 \mathrm{E}-01 & 0 .\end{array}$ $\begin{array}{llllllllllll}6 & 4 & 1 & 1 & 5 & 3.67741 \mathrm{E}+00 & 4.62685 \mathrm{E}-03 & 0.00000 \mathrm{E}+00 & 0.00000 \mathrm{E}+00 & 0.00000 \mathrm{E}+00 & 0\end{array}$

$\begin{array}{lllllllllll}3 & 4 & 1 & 6 & 5 & 1.14737 \mathrm{E}-02 & 2.72164 \mathrm{E}-07 & 0.00000 \mathrm{E}+00 & 0.00000 \mathrm{E}+00 & 0.00000 \mathrm{E}+00 & 0 .\end{array}$

$\begin{array}{lllllllllll}6 & 4 & 1 & 6 & 5 & 0.00000 \mathrm{E}+00 & 0.00000 \mathrm{E}+00 & 0.00000 \mathrm{E}+00 & 0.00000 \mathrm{E}+00 & 0.00000 \mathrm{E}+00 & 0.0\end{array}$

$342155 \quad 0.00000 \mathrm{E}+00 \quad 4.31791 \mathrm{E}+00 \quad 3.93116 \mathrm{E}-01 \quad 4.01496 \mathrm{E}-01 \quad 2.56352 \mathrm{E}-010$

$\begin{array}{llllllllllll}6 & 4 & 2 & 1 & 5 & 0.00000 \mathrm{E}+00 & 2.56381 \mathrm{E}+00 & 2.59628 \mathrm{E}-03-1.60070 \mathrm{E}-04 & 0.00000 \mathrm{E}+00 & 0 .\end{array}$

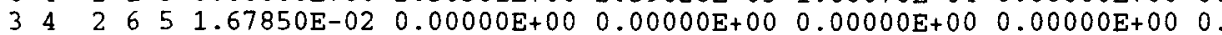

$\begin{array}{lllllllllll}64 & 2 & 6 & 5 & 0.00000 \mathrm{E}+00 & 0.00000 \mathrm{E}+00 & 0.00000 \mathrm{E}+00 & 0.00000 \mathrm{E}+00 & 0.00000 \mathrm{E}+00 & 0 .\end{array}$

$\begin{array}{lllllllllll}3 & 4 & 3 & 1 & 5 & 0.00000 \mathrm{E}+00 & 0.00000 \mathrm{E}+00 & 4.37488 \mathrm{E}+00 & 6.93632 \mathrm{E}-01 & 2.42901 \mathrm{E}-01 & 0\end{array}$

$\begin{array}{lllllllll}6 & 4 & 3 & 1 & 5 & 0.00000 \mathrm{E}+00 & 0.00000 \mathrm{E}+00 & 2.11808 \mathrm{E}+00 & 8.52325 \mathrm{E}-03-1.03201 \mathrm{E}-030\end{array}$

$343655 \quad 6.55569 \mathrm{E}-03 \quad 0.00000 \mathrm{E}+00 \quad 0.00000 \mathrm{E}+00 \quad 0.00000 \mathrm{E}+00 \quad 0.00000 \mathrm{E}+000$.

$\begin{array}{llllllllllll}6 & 4 & 3 & 6 & 5 & 0.00000 \mathrm{E}+00 & 0.00000 \mathrm{E}+00 & 0.00000 \mathrm{E}+00 & 0.00000 \mathrm{E}+00 & 0.00000 \mathrm{E}+00 & 0 .\end{array}$

$344 \quad 4 \quad 1550.00000 \mathrm{E}+00 \quad 0.00000 \mathrm{E}+00 \quad 0.00000 \mathrm{E}+00 \quad 5.94348 \mathrm{E}+00 \quad 4.50153 \mathrm{E}-010$.

$\begin{array}{lllllllll}64 & 4 & 5 & 0.00000 \mathrm{E}+00 & 0.00000 \mathrm{E}+00 & 0.00000 \mathrm{E}+00 & 2.32724 \mathrm{E}+00-5.45163 \mathrm{E}-04 & 0 .\end{array}$

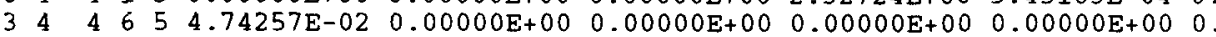

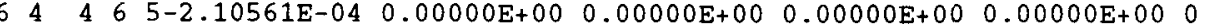

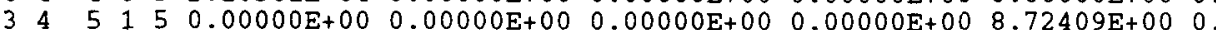

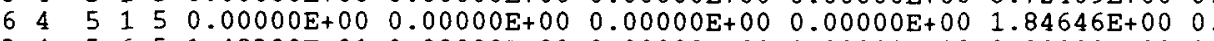

$\begin{array}{lllllllllll}3 & 4 & 5 & 6 & 5 & 1.48300 \mathrm{E}-01 & 0.00000 \mathrm{E}+00 & 0.00000 \mathrm{E}+00 & 0.00000 \mathrm{E}+00 & 0.00000 \mathrm{E}+00 & 0\end{array}$

$\begin{array}{llllllllllll}6 & 4 & 5 & 6 & 5-9.33595 E-03 & 0.00000 E+00 & 0.00000 E+00 & 0.00000 E+00 & 0.00000 E+00 & 0\end{array}$

$\begin{array}{lllllllllll}3 & 4 & 6 & 6 & 5 & 1.08507 \mathrm{E}+01 & 1.09075 \mathrm{E}-01 & 0.00000 \mathrm{E}+00 & 0.00000 \mathrm{E}+00 & 0.00000 \mathrm{E}+00 & 0 .\end{array}$

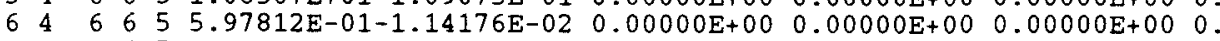

$\begin{array}{lllllllllll}3 & 4 & 7 & 6 & 5 & 0.00000 \mathrm{E}+00 & 1.17761 \mathrm{E}+01 & 1.09779 \mathrm{E}-01 & 2.88866 \mathrm{E}-03 & 5.83747 \mathrm{E}-05 & 0\end{array}$

$647650.00000 \mathrm{E}+00 \quad 5.39618 \mathrm{E}-02-2.01904 \mathrm{E}-02-2.07030 \mathrm{E}-06-3.32253 \mathrm{E}-06 \quad 0$ 
Liating 6. continued.

$\begin{array}{llllllllllll}34 & 8 & 5 & 0.00000 \mathrm{E}+00 & 0.00000 \mathrm{E}+00 & 1.30704 \mathrm{E}+01 & 1.00907 \mathrm{E}-01 & 0.00000 \mathrm{E}+00 & 0 .\end{array}$

$6486650.00000 \mathrm{E}+00 \quad 0.00000 \mathrm{E}+00 \quad 6.96125 \mathrm{E}-02-3.25608 \mathrm{E}-02 \quad 0.00000 \mathrm{E}+00 \quad 0$.

$\begin{array}{llllllllllll}3 & 4 & 9 & 6 & 5 & 0.00000 \mathrm{E}+00 & 0.00000 \mathrm{E}+00 & 0.00000 \mathrm{E}+00 & 1.57787 \mathrm{E}+01 & 4.54604 \mathrm{E}-02 & 0 .\end{array}$

$649655 \quad 0.00000 \mathrm{E}+00 \quad 0.00000 \mathrm{E}+00 \quad 0.00000 \mathrm{E}+00 \quad 5.87709 \mathrm{E}-02-1.42654 \mathrm{E}-020$.

$\begin{array}{lllllllllll}3 & 4 & 10 & 6 & 5 & 0.00000 \mathrm{E}+00 & 0.00000 \mathrm{E}+00 & 0.00000 \mathrm{E}+00 & 0.00000 \mathrm{E}+00 & 1.47297 \mathrm{E}+010 . & 0.0\end{array}$

$\begin{array}{llllllllllll}6 & 4 & 10 & 6 & 5 & 0.00000 \mathrm{E}+00 & 0.00000 \mathrm{E}+00 & 0.00000 \mathrm{E}+00 & 0.00000 \mathrm{E}+00 & 6.04824 \mathrm{E}-02 & 0 .\end{array}$

$\begin{array}{lllllllllll}3 & 4 & 10115 & 5.73258 \mathrm{E}-02 & 0.00000 \mathrm{E}+00 & 0.00000 \mathrm{E}+00 & 0.00000 \mathrm{E}+00 & 0.00000 \mathrm{E}+00 & 0.0\end{array}$

$\begin{array}{llllllllll}64 & 1011 & 5-1.88668 \mathrm{E}-02 & 0.00000 \mathrm{E}+00 & 0.00000 \mathrm{E}+00 & 0.00000 \mathrm{E}+00 & 0.00000 \mathrm{E}+00 & 0 .\end{array}$

$\begin{array}{llllllllll}3411115 & 1.10413 \mathrm{E}+01 & 2.96066 \mathrm{E}-02 & 0.00000 \mathrm{E}+00 & 0.00000 \mathrm{E}+00 & 0.00000 \mathrm{E}+00 & 0 .\end{array}$

$\begin{array}{lllllllll}6 & 4 & 1111 & 5 & 4.09977 \mathrm{E}-02-9.85630 \mathrm{E}-03 & 0.00000 \mathrm{E}+00 & 0.00000 \mathrm{E}+00 & 0.00000 \mathrm{E}+00 & 0 .\end{array}$

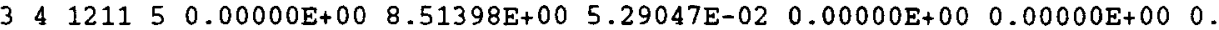

$\begin{array}{lllllllll}6 & 4 & 1211 & 5 & 0.00000 \mathrm{E}+00 & 4.15864 \mathrm{E}-02-1.74887 \mathrm{E}-02 & 0.00000 \mathrm{E}+00 & 0.00000 \mathrm{E}+00 & 0 .\end{array}$

$\begin{array}{lllllllllll}3 & 4 & 1311 & 5 & 0.00000 \mathrm{E}+00 & 0.00000 \mathrm{E}+00 & 9.73857 \mathrm{E}+00 & 1.14577 \mathrm{E}-01 & 0.00000 \mathrm{E}+00 & 0 .\end{array}$

$\begin{array}{lllllllll}6 & 4 & 13115 & 0.00000 \mathrm{E}+00 & 0.00000 \mathrm{E}+00 & 6.56665 \mathrm{E}-02-3.79503 \mathrm{E}-02 & 0.00000 \mathrm{E}+00 & 0 .\end{array}$

$\begin{array}{llllllllll}3 & 4 & 14115 & 0.00000 \mathrm{E}+00 & 0.00000 \mathrm{E}+00 & 0.00000 \mathrm{E}+00 & 1.13162 \mathrm{E}+01 & 1.23985 \mathrm{E}-01 & 0 .\end{array}$

$\begin{array}{lllllllll}6 & 4 & 14115 & 5 & 0.00000 \mathrm{E}+00 & 0.00000 \mathrm{E}+00 & 0.00000 \mathrm{E}+00 & 7.29995 \mathrm{E}-02-4.08232 \mathrm{E}-02 & 0 .\end{array}$

$\begin{array}{llllllllll}3 & 4 & 1511 & 5 & 0.00000 \mathrm{E}+00 & 0.00000 \mathrm{E}+00 & 0.00000 \mathrm{E}+00 & 0.00000 \mathrm{E}+00 & 7.81324 \mathrm{E}+00 & 0 .\end{array}$

$\begin{array}{llllllllll}64 & 15115 & 0.00000 \mathrm{E}+00 & 0.00000 \mathrm{E}+00 & 0.00000 \mathrm{E}+00 & 0.00000 \mathrm{E}+00 & 2.32600 \mathrm{E}-02 & 0 .\end{array}$

$\begin{array}{lllllllllll}34 & 1616 & 1 & 7.87883 E+00 & 0.00000 E+00 & 0.00000 E+00 & 0.00000 E+00 & 0.00000 E+00 & 0 .\end{array}$

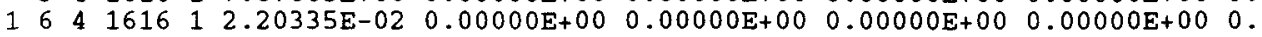


Lleting 7. Table 1 Case 2, scNup Input using Bansen-Roach crose sections.

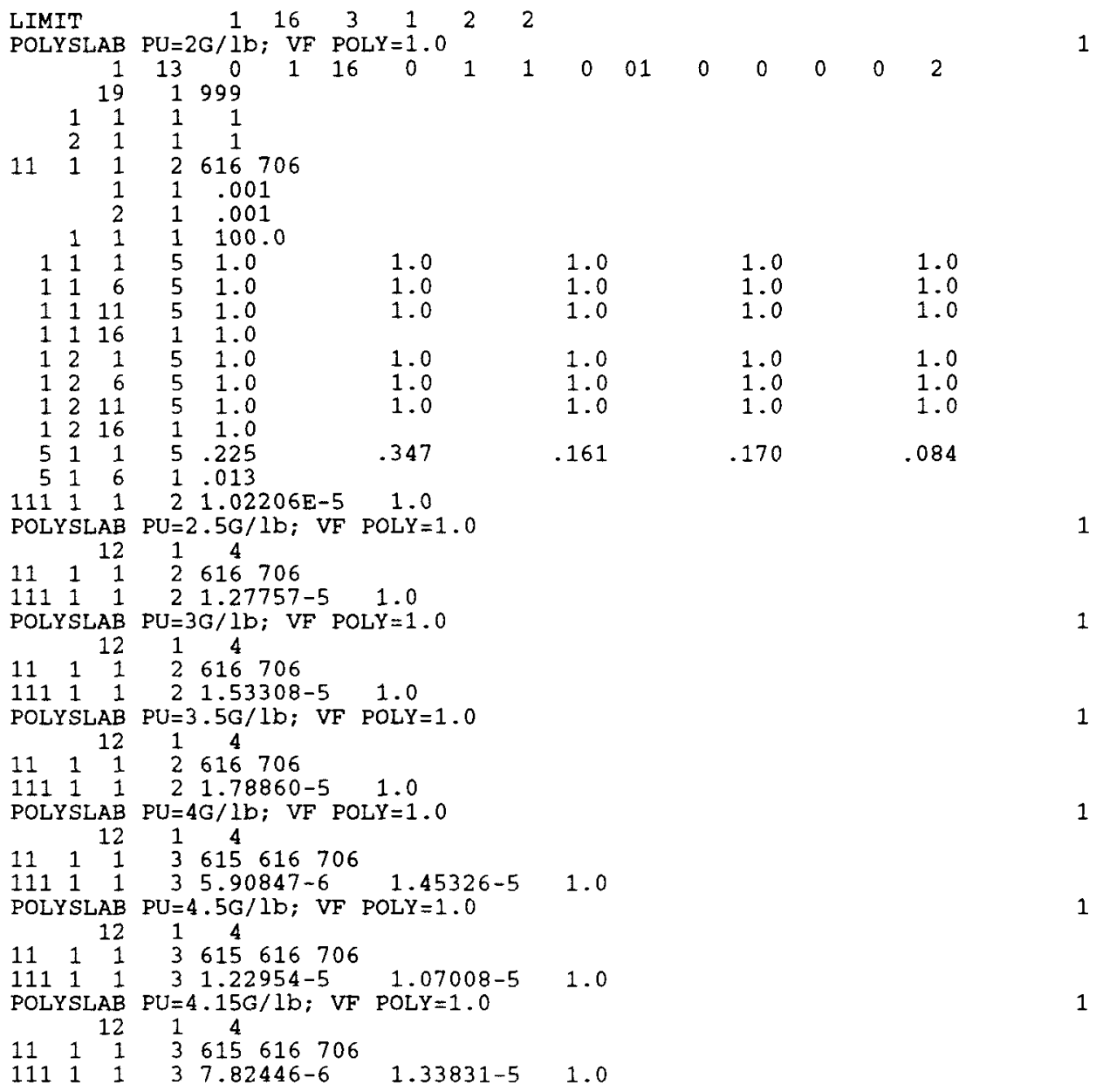

Listing 8. Table 1 case 2, KBNO-V.a Input using Bansen-Roach cross sections.

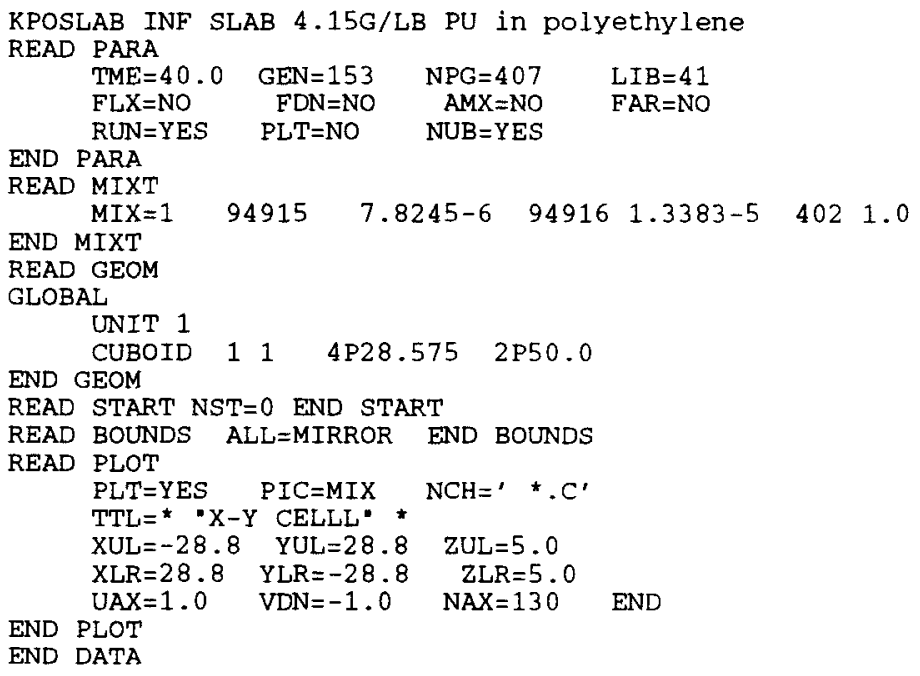


Liating 9. Table 1 case 2, Kwso-v.a Input using csas and 27-group cross sections.

$=\operatorname{CSAS} 25$

CPOSLAB $4.15 \mathrm{~g}$ Pu $/ \mathrm{lb}$ poly

27GROUPNDF4 INFHOMMEDIUM

PU-239 $1002.1208-5$ END

POLYETHYLENE 1 1.0 END

END COMP

KPOSLAB INF SLAB 4.15G/LB PU in poly

READ PARA

\begin{tabular}{|c|c|c|}
\hline $\begin{array}{l}\text { TME }=40.0 \\
F L X=N O\end{array}$ & $\begin{aligned} G E N & =153 \\
F D N & =N O\end{aligned}$ & $\begin{array}{r}N P G=407 \\
A M X=N O\end{array}$ \\
\hline RUN $=Y E S$ & $\mathrm{PLT}=\mathrm{NO}$ & NUB $=Y E S$ \\
\hline
\end{tabular}

END PARA

GLOBAI

UNIT 1

CUBOID 1114 P $28.575 \quad 2$ P50.0

END GEOM

READ START NST $=0$ END START

READ BOUNDS ALL=MIRROR END BOUNDS

READ PLOT

PLT $=$ YES PIC $=$ MIX NCH $={ }^{\prime} * \mathrm{C}^{\prime}$

TTTL $=$ * "X-Y CELLL" *

$X U L=-28.8 \quad$ YUL $=28.8 \quad$ ZUL $=5.0$

$\mathrm{XLR}=28.8 \quad \mathrm{YLR}=-28.8 \quad \mathrm{ZLR}=5.0$

END PLOT

$\mathrm{UAX}=1.0 \quad \mathrm{VDN}=-1.0 \quad \mathrm{NAX}=130 \quad$ END

END DATA

Listing 10. Table 1 Case 2, MCNP Input.

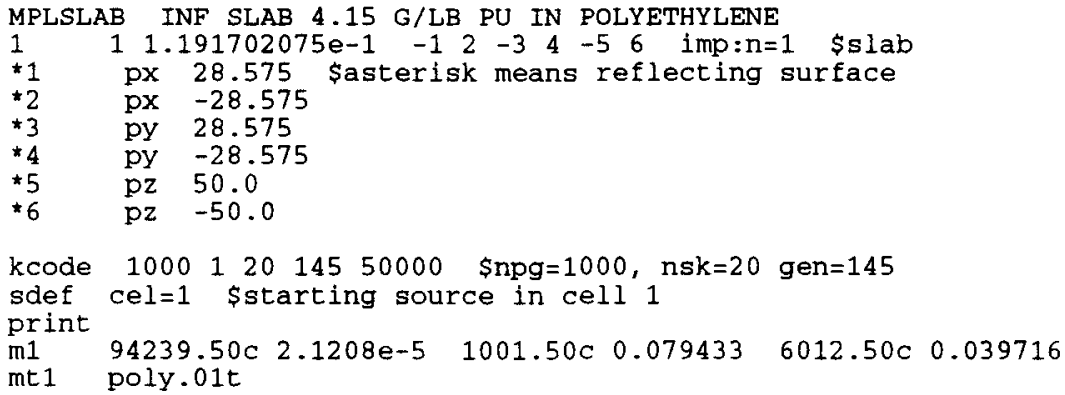

Listing 11. Table 1 case 2, comiss input.

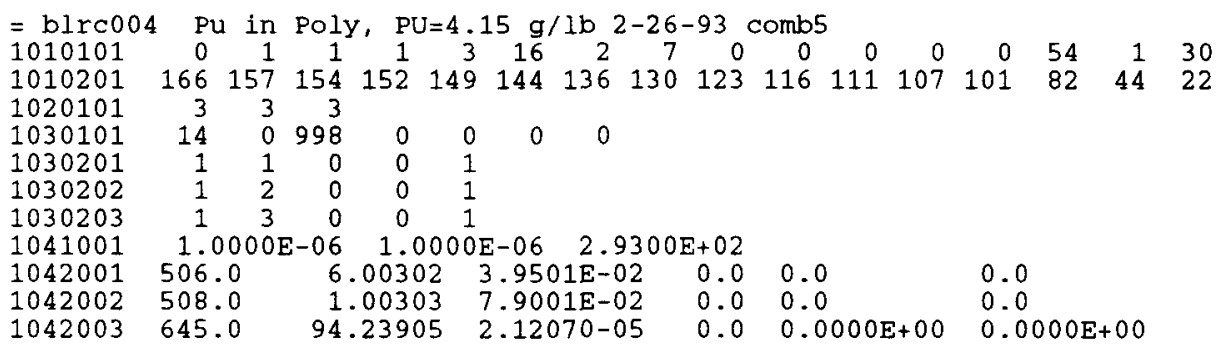


L1sting 12 .

Table 1 case 2, scxp Input with comBIns genorated cross ections.

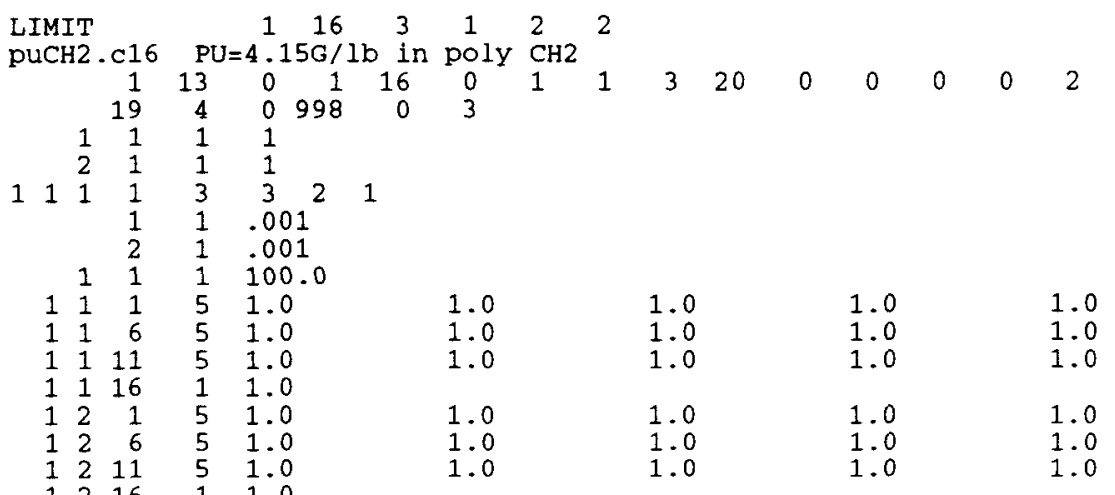

$\begin{array}{rrrrrrrrr}5 & 1 & 1 & 5 & 2.55974 \mathrm{E}-01 & 3.48185 \mathrm{E}-01 & 1.71622 \mathrm{E}-01 & 1.39795 \mathrm{E}-01 & 7.01995 \mathrm{E}-02\end{array}$

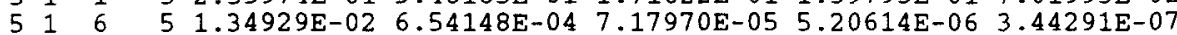

$\begin{array}{llllll}5111 & 4 & 4.84487 \mathrm{E}-08 & 1.24487 \mathrm{E}-08 & 9.90516 \mathrm{E}-10 & 3.69914 \mathrm{E}-10\end{array}$

111 1 $111302.12070 \mathrm{E}-05 \quad 7.900100-02 \quad 3.950100-02$

0 1 11 CARBON VERS 5 (FAST) + CARBON 300K P0+P1 SU (THERMAL)

1111152.70443 E-01 1.83760 E-01 $1.48693 E-01 \quad 1.14686$ E-01 $8.89333 E-02 \quad 0$.

$\begin{array}{lllllllllllll}1 & 1 & 6 & 1 & 5 & 7.66185 \mathrm{E}-02 & 7.45192 \mathrm{E}-02 & 7.44052 \mathrm{E}-02 & 7.44543 \mathrm{E}-02 & 7.44091 \mathrm{E}-02 & 0\end{array}$

$\begin{array}{llllllllllll}1 & 1 & 11 & 1 & 5 & 7.45725 \mathrm{E}-02 & 7.44886 \mathrm{E}-02 & 7.44860 \mathrm{E}-02 & 7.44040 \mathrm{E}-02 & 7.22290 \mathrm{E}-02 & 0 .\end{array}$

$\begin{array}{llllllllllll}1 & 1 & 16 & 1 & 1 & 6.45930 \mathrm{E}-02 & 0.00000 \mathrm{E}+00 & 0.00000 \mathrm{E}+00 & 0.00000 \mathrm{E}+00 & 0.00000 \mathrm{E}+00 & 0.00\end{array}$

$\begin{array}{llllllllllllll}1 & 1 & 2 & 5 & 6.74008 \mathrm{E}-03 & 6.31203 \mathrm{E}-06 & 1.59958 \mathrm{E}-06 & 1.05698 \mathrm{E}-06 & 9.33671 \mathrm{E}-07 & 0\end{array}$

$1166250.54515 \mathrm{E}-07 \quad 6.01811 \mathrm{E}-06 \quad 1.66994 \mathrm{E}-05 \quad 3.57934 \mathrm{E}-05 \quad 7.45418 \mathrm{E}-05 \quad 0$.

$\begin{array}{lllllllllllll}1 & 1 & 11 & 5 & 1.30182 \mathrm{E}-04 & 2.46287 \mathrm{E}-04 & 4.25073 \mathrm{E}-04 & 6.61223 \mathrm{E}-04 & 1.41329 \mathrm{E}-03 & 0 .\end{array}$

$11162113.03740 E-03 \quad 0.00000 E+00 \quad 0.00000 E+00 \quad 0.00000 E+00 \quad 0.00000 E+00 \quad 0$.

$\begin{array}{llllllllllll}4 & 1 & 1 & 0 & 5 & 1.52969 E+00 & 1.69074 E+00 & 2.21020 E+00 & 2.89092 E+00 \quad 3.70040 E+00 & 0 .\end{array}$

$41 \quad 6 \quad 0 \quad 5 \quad 4.27586 \mathrm{E}+00 \quad 4.43993 \mathrm{E}+00 \quad 4.46655 \mathrm{E}+00 \quad 4.47207 \mathrm{E}+00 \quad 4.47336 \mathrm{E}+00 \quad 0$.

$4111=0514.47363 \mathrm{E}+00 \quad 4.47380 \mathrm{E}+00 \quad 4.47401 \mathrm{E}+00 \quad 4.47429 \mathrm{E}+00 \quad 4.59336 \mathrm{E}+00 \quad 0$.

$4116014.95326 \mathrm{E}+00 \quad 0.00000 \mathrm{E}+00 \quad 0.00000 \mathrm{E}+00 \quad 0.00000 \mathrm{E}+00 \quad 0.00000 \mathrm{E}+00 \quad 0$

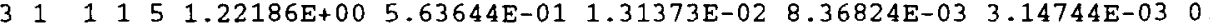

$6111155.15292 \mathrm{E}-01-2.29484 \mathrm{E}-01 \quad 1.20824 \mathrm{E}-03 \quad 6.42717 \mathrm{E}-04-1.49305 \mathrm{E}-04 \quad 0$

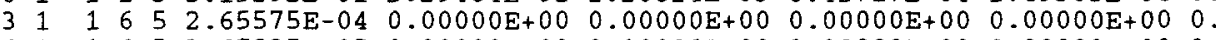

$\begin{array}{llllllllllll}6 & 1 & 1 & 5 & 5-3.67825 \mathrm{E}-05 & 0.00000 \mathrm{E}+00 & 0.00000 \mathrm{E}+00 & 0.00000 \mathrm{E}+00 & 0.00000 \mathrm{E}+00 & 0\end{array}$

$312150.00000 E+00 \quad 1.42909 E+00 \quad 4.00783 E-01 \quad 0.00000 E+00 \quad 0.00000 E+00 \quad 0$.

$\begin{array}{lllllllllll}6 & 1 & 2 & 5 & 0.00000 \mathrm{E}+00 & 2.41616 \mathrm{E}-01-1.02481 \mathrm{E}-01 & 0.00000 \mathrm{E}+00 & 0.00000 \mathrm{E}+00 & 0\end{array}$

$\begin{array}{llllllllllll}3 & 1 & 3 & 1 & 5 & 0.00000 \mathrm{E}+00 & 0.00000 \mathrm{E}+00 & 1.68912 \mathrm{E}+00 & 8.19632 \mathrm{E}-01 & 0.00000 \mathrm{E}+00 & 0.00\end{array}$

$\begin{array}{lllllllllllll}6 & 3 & 1 & 5 & 0.00000 E+00 & 0.00000 E+00 & 4.67252 E-01-1.68692 E-01 & 0.00000 E+00 & 0\end{array}$

$3144150.00000 E+00 \quad 0.00000 E+00 \quad 0.00000 E+00 \quad 2.61927 E+00 \quad 6.16752 E-010$.

$\begin{array}{lllllllllll}6 & 4 & 1 & 5 & 0.00000 \mathrm{E}+00 & 0.00000 \mathrm{E}+00 & 0.00000 \mathrm{E}+00 & 4.86603 \mathrm{E}-01-1.41496 \mathrm{E}-01 & 0.0 .\end{array}$

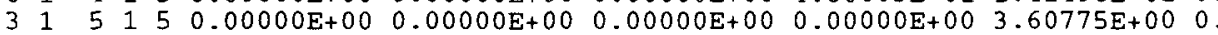

$\begin{array}{lllllllllllllll}6 & 1 & 5 & 1 & 5 & 0.00000 E+00 & 0.00000 E+00 & 0.00000 E+00 & 0.00000 E+00 & 4.41277 E-01 & 0\end{array}$

$\begin{array}{llllllllllll}3 & 1 & 5 & 6 & 5 & 4.24608 \mathrm{E}-01 & 0.00000 \mathrm{E}+00 & 0.00000 \mathrm{E}+00 & 0.00000 \mathrm{E}+00 & 0.00000 \mathrm{E}+00 & 0.00\end{array}$

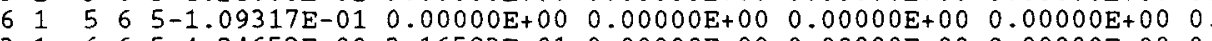

$\begin{array}{llllllllllllll}3 & 1 & 6 & 6 & 5 & 4.24652 \mathrm{E}+00 & 3.16583 \mathrm{E}-01 & 0.00000 \mathrm{E}+00 & 0.00000 \mathrm{E}+00 & 0.00000 \mathrm{E}+00 & 0\end{array}$

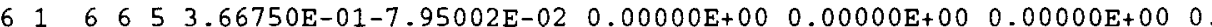

$31176550.00000 \mathrm{E}+00 \quad 4.21855 \mathrm{E}+00 \quad 4.87822 \mathrm{E}-01 \quad 0.00000 \mathrm{E}+00 \quad 0.00000 \mathrm{E}+00 \quad 0$

$\begin{array}{llllllllllll}6 & 7 & 6 & 5 & 0.00000 \mathrm{E}+00 & 4.03013 \mathrm{E}-01-1.36561 \mathrm{E}-01 & 0.00000 \mathrm{E}+00 & 0.00000 \mathrm{E}+00 & 0.0\end{array}$

$31186650.00000 E+00 \quad 0.00000 E+00 \quad 4.30456 E+00 \quad 4.27119 E-01 \quad 0.00000 E+00 \quad 0$

$6188650.00000 \mathrm{E}+00 \quad 0.00000 \mathrm{E}+00 \quad 3.87787 \mathrm{E}-01-1.22643 \mathrm{E}-01 \quad 0.00000 \mathrm{E}+00 \quad 0$.

$\begin{array}{lllllllllllll}3 & 1 & 6 & 5 & 0.00000 E+00 & 0.00000 E+00 & 0.00000 E+00 & 4.30834 E+00 & 4.29175 E-01 & 0 .\end{array}$

$\begin{array}{llllllllll}6 & 9 & 6 & 5 & 0.00000 E+00 & 0.00000 E+00 & 0.00000 E+00 & 3.90920 E-01-1.25444 E-01 & 0 .\end{array}$

$\begin{array}{llllllllllllll}3 & 1 & 10 & 6 & 5 & 0.00000 E+00 & 0.00000 E+00 & 0.00000 E+00 & 0.00000 E+00 & 4.14531 E+00 & 0\end{array}$

$611106650.00000 E+00 \quad 0.00000 E+00 \quad 0.00000 E+00 \quad 0.00000 E+00 \quad 4.39062 E-010$.

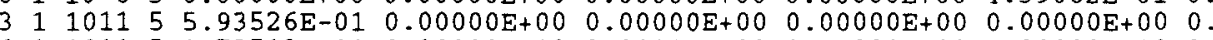

$\begin{array}{llllllllll}6 & 1 & 1011 & 5-1.73512 \mathrm{E}-01 & 0.00000 \mathrm{E}+00 & 0.00000 \mathrm{E}+00 & 0.00000 \mathrm{E}+00 & 0.00000 \mathrm{E}+00 & 0.0\end{array}$

$\begin{array}{llllllllllll}3 & 1 & 1111 & 5 & 3.99198 E+00 & 7.47079 E-01 & 0.00000 E+00 & 0.00000 E+00 & 0.00000 E+00 & 0 .\end{array}$

$\begin{array}{llllllllll}6 & 1 & 1111 & 5 & 4.88528 \mathrm{E}-01-2.22965 \mathrm{E}-01 & 0.00000 \mathrm{E}+00 & 0.00000 \mathrm{E}+00 & 0.00000 \mathrm{E}+000 . & 0.00\end{array}$

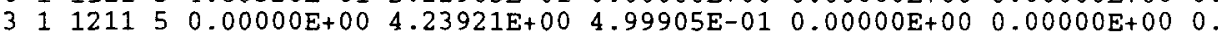

$\begin{array}{llllllllllll}6 & 1 & 1211 & 5 & 0.00000 \mathrm{E}+00 & 4.12732 \mathrm{E}-01-1.47166 \mathrm{E}-01 & 0.00000 \mathrm{E}+00 & 0.00000 \mathrm{E}+00 & 0\end{array}$

$\begin{array}{llllllllllll}3 & 1 & 1311 & 5 & 0.00000 E+00 & 0.00000 E+00 & 3.73538 E+00 & 1.00378 E+00 & 0.00000 E+00 & 0 .\end{array}$

$61131150.00000 E+00 \quad 0.00000 E+00 \quad 5.61697 E-01-2.96129 E-010.00000 E+000$.

$31141150.00000 E+00 \quad 0.00000 E+00 \quad 0.00000 E+00 \quad 3.98371 E+00 \quad 7.55483 E-01 \quad 0$.

$\begin{array}{lllllllll}6 & 1 & 1411 & 5 & 0.00000 E+00 & 0.00000 E+00 & 0.00000 E+00 & 4.83957 E-01-2.18387 E-01 & 0 .\end{array}$

$\begin{array}{llllllllll}3 & 1 & 1511 & 5 & 0.00000 \mathrm{E}+00 & 0.00000 \mathrm{E}+00 & 0.00000 \mathrm{E}+00 & 1.18098 \mathrm{E}-02 & 4.14170 \mathrm{E}+00 & 0.0\end{array}$

$\begin{array}{llllllllllll}6 & 1 & 1511 & 5 & 0.00000 \mathrm{E}+00 & 0.00000 \mathrm{E}+00 & 0.00000 \mathrm{E}+00 & 6.58154 \mathrm{E}-04 & 2.47982 \mathrm{E}-01 & 0.0 .\end{array}$

$\begin{array}{lllllllllll}3 & 1 & 1516 & 1 & 5.91693 \mathrm{E}-01 & 0.00000 \mathrm{E}+00 & 0.00000 \mathrm{E}+00 & 0.00000 \mathrm{E}+00 & 0.00000 \mathrm{E}+00 & 0 .\end{array}$

$\begin{array}{llllllllll}6 & 1 & 1516 & 1-9.53772 \mathrm{E}-02 & 0.00000 \mathrm{E}+00 & 0.00000 \mathrm{E}+00 & 0.00000 \mathrm{E}+00 & 0.00000 \mathrm{E}+00 & 0 .\end{array}$

$\begin{array}{lllllllllll}3 & 1 & 1611 & 5 & 0.00000 \mathrm{E}+00 & 0.00000 \mathrm{E}+00 & 0.00000 \mathrm{E}+00 & 2.50910 \mathrm{E}-08 & 9.76632 \mathrm{E}-02 & 0.0 .\end{array}$

$61161150.00000 \mathrm{E}+00 \quad 0.00000 \mathrm{E}+00 \quad 0.00000 \mathrm{E}+00-1.20752 \mathrm{E}-08-1.74429 \mathrm{E}-020$

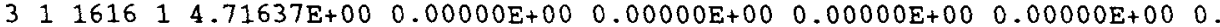


$\begin{array}{lllllllllll}16 & 1 & 1616 & 1-1.18748 \mathrm{E}-01 & 0.00000 \mathrm{E}+00 & 0.00000 \mathrm{E}+00 & 0.00000 \mathrm{E}+00 & 0.00000 \mathrm{E}+000 & 0 .\end{array}$ 0 H HYDROGEN VERS 5 (FAST) + HYDROGEN IN POLYETH (THERMAL)

$121152.53327 \mathrm{E}-011.92194 \mathrm{E}-011.84981 \mathrm{E}-01 \quad 1.79448 \mathrm{E}-01 \quad 1.49469 \mathrm{E}-010$.

$\begin{array}{lllllllllllll}1 & 2 & 6 & 1 & 5 & 9.34230 \mathrm{E}-02 & 6.38813 \mathrm{E}-02 & 5.46883 \mathrm{E}-02 & 5.10160 \mathrm{E}-02 & 4.98216 \mathrm{E}-02 & 0.0\end{array}$

$\begin{array}{llllllllllll}1 & 2 & 11 & 1 & 5 & 4.95292 \mathrm{E}-02 & 4.91947 \mathrm{E}-02 & 4.89648 \mathrm{E}-02 & 4.91166 \mathrm{E}-02 & 2.91199 \mathrm{E}-02 & 0 .\end{array}$

$\begin{array}{llllllllllll}1 & 2 & 16 & 1 & 1 & 2.11467 \mathrm{E}-02 & 0.00000 \mathrm{E}+00 & 0.00000 \mathrm{E}+00 & 0.00000 \mathrm{E}+00 & 0.00000 \mathrm{E}+00 & 0.0 .\end{array}$

$12 \quad 1 \quad 2 \quad 5 \quad 3.58545 E-05 \quad 3.45298 E-05 \quad 3.45235 E-05 \quad 3.72961 E-05 \quad 6.20817 E-05 \quad 0$.

$12662502.06437 E-04 \quad 6.17355 E-04 \quad 1.45524 E-03 \quad 3.48580 E-03 \quad 7.28529 E-03 \quad 0$.

$\begin{array}{lllllllllll}1 & 2 & 11 & 2 & 5 & 1.27271 E-02 & 2.39977 E-02 & 4.14915 E-02 & 6.45472 E-02 & 1.39646 E-01 & 0 .\end{array}$

$1216213.00124 E-01 \quad 0.00000 E+00 \quad 0.00000 E+00 \quad 0.00000 E+00 \quad 0.00000 E+00 \quad 0$.

$\begin{array}{lllllllllll}4 & 2 & 1 & 0 & 5 & 6.55099 \mathrm{E}-01 & 9.94591 \mathrm{E}-01 & 1.39117 \mathrm{E}+00 & 1.92510 \mathrm{E}+00 & 3.18041 \mathrm{E}+00 \quad 0 .\end{array}$

$4266055.37546 \mathrm{E}+00 \quad 6.49236 \mathrm{E}+00 \quad 6.74212 \mathrm{E}+00 \quad 6.80048 \mathrm{E}+00 \quad .81228 \mathrm{E}+00 \quad 0$.

$42110056.81773 \mathrm{E}+00 \quad 6.82897 \mathrm{E}+00 \quad 6.84646 \mathrm{E}+00 \quad 6.86955 \mathrm{E}+00: .28167 \mathrm{E}+010$.

$4216 \quad 0 \quad 12.03668 \mathrm{E}+01 \quad 0.00000 \mathrm{E}+00 \quad 0.00000 \mathrm{E}+00 \quad 0.00000 \mathrm{E}+00 \quad 0.00000 \mathrm{E}+00 \quad 0$.

$\begin{array}{llllllllllll}3 & 2 & 1 & 5 & 4.92094 \mathrm{E}-01 & 7.07536 \mathrm{E}-01 & 2.50980 \mathrm{E}-01 & 2.04806 \mathrm{E}-01 & 1.31145 \mathrm{E}-01 & 0 .\end{array}$

$\begin{array}{llllllllllll}6 & 2 & 1 & 1 & 5 & 4.64324 \mathrm{E}-01 & 4.84286 \mathrm{E}-01 & 1.23817 \mathrm{E}-01 & 7.51996 \mathrm{E}-02 & 3.08096 \mathrm{E}-02 & 0 .\end{array}$

$\begin{array}{llllllllllll}3 & 2 & 1 & 6 & 5 & 4.55937 \mathrm{E}-02 & 5.54599 \mathrm{E}-03 & 1.31616 \mathrm{E}-03 & 2.28717 \mathrm{E}-04 & 3.43224 \mathrm{E}-05 & 0.3 .\end{array}$

$\begin{array}{llllllllllll}6 & 2 & 1 & 6 & 5 & 5.42825 \mathrm{E}-03 & 2.94878 \mathrm{E}-04 & 5.18749 \mathrm{E}-05 & 1.23169 \mathrm{E}-05 & 3.57101 \mathrm{E}-06 & 0 .\end{array}$

$\begin{array}{llllllllllll}3 & 2 & 111 & 5 & 8.71201 \mathrm{E}-06 & 3.93887 \mathrm{E}-06 & 5.93975 \mathrm{E}-07 & 2.15745 \mathrm{E}-07 & 0.00000 \mathrm{E}+00 & 0 .\end{array}$

$\begin{array}{lllllllllll}6 & 2 & 111 & 5 & 1.57786 \mathrm{E}-06 & 1.27320 \mathrm{E}-06 & 3.51065 \mathrm{E}-07 & 1.62428 \mathrm{E}-07 & 0.00000 \mathrm{E}+00 & 0 .\end{array}$

$322150.00000 E+00 \quad 8.16505 E-01 \quad 8.45207 E-01 \quad 6.88810 E-014.40623 E-010$.

$\begin{array}{llllllllllll}6 & 2 & 1 & 5 & 0.00000 E+00 & 7.43894 E-01 & 6.47351 E-01 & 3.92353 E-01 & 1.60217 E-01 & 0 .\end{array}$

$32526 \begin{array}{lllllllll}3 & 2 & 6 & 1.53109 \mathrm{E}-01 & 1.83860 \mathrm{E}-02 & 4.34104 \mathrm{E}-03 & 7.54364 \mathrm{E}-04 & 1.13203 \mathrm{E}-04 & 0 .\end{array}$

$\begin{array}{llllllllllll}6 & 2 & 2 & 6 & 5 & 2.78855 \mathrm{E}-02 & 1.38756 \mathrm{E}-03 & 1.97778 \mathrm{E}-04 & 3.48719 \mathrm{E}-05 & 8.92261 \mathrm{E}-06 & 0 .\end{array}$

$\begin{array}{lllllllllll}3 & 2 & 211 & 5 & 2.87342 \mathrm{E}-05 & 1.29913 \mathrm{E}-05 & 1.96877 \mathrm{E}-06 & 1.10770 \mathrm{E}-06 & 1.09658 \mathrm{E}-07 & 0 .\end{array}$

$\begin{array}{lllllllllll}6 & 2 & 211 & 5 & 3.83680 \mathrm{E}-06 & 3.06884 \mathrm{E}-06 & 8.54345 \mathrm{E}-07 & 7.31110 \mathrm{E}-07 & 9.41546 \mathrm{E}-08 & 0 .\end{array}$

$32 \quad 3150.00000 \mathrm{E}+00 \quad 0.00000 \mathrm{E}+00 \quad 8.40229 \mathrm{E}-011.75403 \mathrm{E}+00 \quad 1.12041 \mathrm{E}+00 \quad 0$.

$623 \quad \begin{array}{llllllllll}6 & 3 & 0.00000 E+00 & 0.00000 E+00 & 7.90151 E-01 & 1.33748 E+00 & 5.44943 E-01 & 0 .\end{array}$

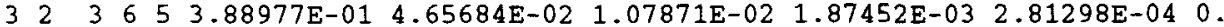

$\begin{array}{lllllllllllll}6 & 2 & 3 & 6 & 5 & 9.43290 \mathrm{E}-02 & 4.54642 \mathrm{E}-03 & 5.69935 \mathrm{E}-04 & 7.92122 \mathrm{E}-05 & 1.74525 \mathrm{E}-05 & 0 .\end{array}$

$\begin{array}{lllllllllll}3 & 2 & 311 & 5 & 7.14015 \mathrm{E}-05 & 3.22821 \mathrm{E}-05 & 4.89219 \mathrm{E}-06 & 2.76854 \mathrm{E}-06 & 9.58702 \mathrm{E}-07 & 0 .\end{array}$

$\begin{array}{llllllllllll}6 & 2 & 311 & 5 & 7.22089 \mathrm{E}-06 & 5.70063 \mathrm{E}-06 & 1.57997 \mathrm{E}-06 & 1.36322 \mathrm{E}-06 & 7.46765 \mathrm{E}-07 & 0 .\end{array}$

$\begin{array}{llllllllll}3 & 2 & 4 & 5 & 0.00000 \mathrm{E}+00 & 0.00000 \mathrm{E}+00 & 0.00000 \mathrm{E}+00 & 1.70178 \mathrm{E}+00 & 2.87294 \mathrm{E}+00 & 0.00\end{array}$

$624150.00000 \mathrm{E}+00 \quad 0.00000 \mathrm{E}+00 \quad 0.00000 \mathrm{E}+00 \quad 1.55367 \mathrm{E}+00 \quad 1.90179 \mathrm{E}+00 \quad 0$.

$3244650.97496 \mathrm{E}-01 \quad 1.20936 \mathrm{E}-01 \quad 2.76684 \mathrm{E}-02 \quad 4.80806 \mathrm{E}-03 \quad 7.21517 \mathrm{E}-04 \quad 0$.

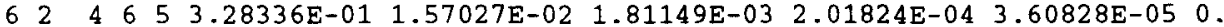

$\begin{array}{lllllllllll}32 & 411 & 5 & 1.83142 \mathrm{E}-04 & 8.28020 \mathrm{E}-05 & 1.25483 \mathrm{E}-05 & 7.10117 \mathrm{E}-06 & 3.31008 \mathrm{E}-06 & 0 .\end{array}$

$\begin{array}{llllllllll}6 & 2 & 411 & 5 & 1.39476 \mathrm{E}-05 & 1.07417 \mathrm{E}-05 & 2.95146 \mathrm{E}-06 & 2.54150 \mathrm{E}-06 & 2.09054 \mathrm{E}-06 & 0 .\end{array}$

$\begin{array}{lllllllllllll}3 & 2 & 416 & 1 & 1.72106 \mathrm{E}-09 & 0.00000 \mathrm{E}+00 & 0.00000 \mathrm{E}+00 & 0.00000 \mathrm{E}+00 & 0.00000 \mathrm{E}+00 & 0 .\end{array}$

$\begin{array}{llllllllllll}62 & 416 & 1 & 1.41174 \mathrm{E}-09 & 0.00000 \mathrm{E}+00 & 0.00000 \mathrm{E}+00 & 0.00000 \mathrm{E}+00 & 0.00000 \mathrm{E}+00 & 0.00\end{array}$

$\begin{array}{lllllllllllll}3 & 2 & 5 & 1 & 5 & 0.00000 \mathrm{E}+00 & 0.00000 \mathrm{E}+00 & 0.00000 \mathrm{E}+00 & 0.00000 \mathrm{E}+00 & 4.00551 \mathrm{E}+00 & 0.00 .\end{array}$

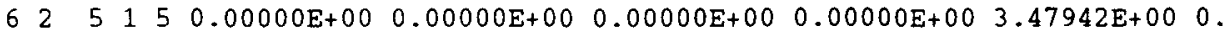

$3255655 \quad 4.59011 E+00 \quad 5.58127 E-01 \quad 1.30768 E-012.21255 E-02 \quad 3.32025 E-03 \quad 0$.

$\begin{array}{lllllllllllll}6 & 2 & 5 & 6 & 5 & 2.51793 \mathrm{E}+00 & 1.18942 \mathrm{E}-01 & 1.33093 \mathrm{E}-02 & 1.12215 \mathrm{E}-03 & 1.34684 \mathrm{E}-04 & 0 .\end{array}$

$\begin{array}{llllllllllll}3 & 2 & 511 & 5 & 8.42773 \mathrm{E}-04 & 3.81035 \mathrm{E}-04 & 5.77440 \mathrm{E}-05 & 3.26779 \mathrm{E}-05 & 1.56427 \mathrm{E}-05 & 0 .\end{array}$

$\begin{array}{llllllllllll}6 & 2 & 511 & 5 & 4.25481 \mathrm{E}-05 & 2.99738 \mathrm{E}-05 & 7.96265 \mathrm{E}-06 & 6.80234 \mathrm{E}-06 & 6.02059 \mathrm{E}-06 & 0 .\end{array}$

$\begin{array}{lllllllllll}32 & 5161 & 2.53499 \mathrm{E}-06 & 0.00000 \mathrm{E}+00 & 0.00000 \mathrm{E}+00 & 0.00000 \mathrm{E}+00 & 0.00000 \mathrm{E}+00 & 0.00\end{array}$

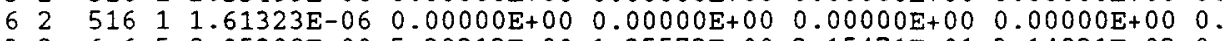

$\begin{array}{lllllllllllll}3 & 2 & 6 & 6 & 5 & 8.95298 \mathrm{E}+00 & 5.29212 \mathrm{E}+00 & 1.25572 \mathrm{E}+00 & 2.15471 \mathrm{E}-01 & 3.14821 \mathrm{E}-02 & 0 .\end{array}$.

$\begin{array}{llllllllllllll}6 & 2 & 6 & 6 & 5 & 7.33977 \mathrm{E}+00 & 2.72180 \mathrm{E}+00 & 2.99157 \mathrm{E}-01 & 2.22045 \mathrm{E}-02 & 1.65576 \mathrm{E}-03 & 0 .\end{array}$

$\begin{array}{llllllllllll}3 & 2 & 611 & 5 & 7.99107 \mathrm{E}-03 & 3.61292 \mathrm{E}-03 & 5.47521 \mathrm{E}-04 & 3.09847 \mathrm{E}-04 & 1.43252 \mathrm{E}-04 & 0 .\end{array}$

$\begin{array}{lllllllllll}6 & 2 & 611 & 5 & 3.24058 \mathrm{E}-04 & 1.56753 \mathrm{E}-04 & 3.39990 \mathrm{E}-05 & 2.74734 \mathrm{E}-05 & 2.19805 \mathrm{E}-05 & 0 .\end{array}$

$\begin{array}{lllllllllllll}32 & 616 & 1 & 4.16116 \mathrm{E}-05 & 0.00000 \mathrm{E}+00 & 0.00000 \mathrm{E}+00 & 0.00000 \mathrm{E}+00 & 0.00000 \mathrm{E}+00 & 0.0 .\end{array}$

$\begin{array}{llllllllll}62 & 616 & 1 & 1.47051 E-05 & 0.00000 E+00 & 0.00000 E+00 & 0.00000 E+00 & 0.00000 E+00 & 0.0\end{array}$

$\begin{array}{lllllllllllll}3 & 2 & 7 & 6 & 5 & 0.00000 \mathrm{E}+00 & 9.39221 \mathrm{E}+00 & 8.33561 \mathrm{E}+00 & 1.44851 \mathrm{E}+00 & 2.14977 \mathrm{E}-01 & 0 .\end{array}$

$\begin{array}{lllllllllll}6 & 2 & 7 & 6 & 5 & 0.00000 \mathrm{E}+00 & 7.94046 \mathrm{E}+00 & 4.67425 \mathrm{E}+00 & 3.40863 \mathrm{E}-01 & 2.30630 \mathrm{E}-02 & 0 .\end{array}$

$\begin{array}{lllllllllllll}32 & 711 & 5 & 5.30400 \mathrm{E}-02 & 2.39805 \mathrm{E}-02 & 3.63412 \mathrm{E}-03 & 2.05658 \mathrm{E}-03 & 9.45584 \mathrm{E}-04 & 0 .\end{array}$

$\begin{array}{llllllllllll}62 & 711 & 5 & 3.41448 \mathrm{E}-03 & 1.09832 \mathrm{E}-03 & 1.52123 \mathrm{E}-04 & 1.01245 \mathrm{E}-04 & 6.58505 \mathrm{E}-05 & 0 .\end{array}$

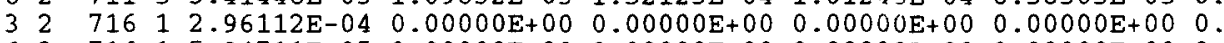

$\begin{array}{llllllllllll}62 & 716 & 1 & 5.94711 \mathrm{E}-05 & 0.00000 \mathrm{E}+00 & 0.00000 \mathrm{E}+00 & 0.00000 \mathrm{E}+00 & 0.00000 \mathrm{E}+00 \quad 0 .\end{array}$

$\begin{array}{lllllllllllll}3 & 2 & 8 & 6 & 5 & 0.00000 E+00 & 0.00000 E+00 & 1.06959 E+01 & 7.89956 E+00 & 1.18544 E+00 & 0 .\end{array}$

$\begin{array}{lllllllllllll}6 & 2 & 8 & 6 & 5 & 0.00000 E+00 & 0.00000 E+00 & 8.80273 E+00 & 4.36324 E+00 & 2.90228 E-01 & 0 .\end{array}$

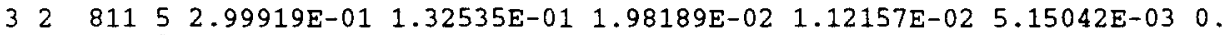

$\begin{array}{lllllllllll}6 & 2 & 811 & 5 & 4.14266 \mathrm{E}-02 & 1.09506 \mathrm{E}-02 & 1.00937 \mathrm{E}-03 & 4.82360 \mathrm{E}-04 & 1.43697 \mathrm{E}-04 & 0 .\end{array}$

$\begin{array}{llllllllll}3 & 2 & 816 & 1 & 1.63206 \mathrm{E}-03 & 0.00000 \mathrm{E}+00 & 0.00000 \mathrm{E}+00 & 0.00000 \mathrm{E}+00 & 0.00000 \mathrm{E}+00 & 0.00\end{array}$

$\begin{array}{llllllllll}62 & 816 & 1 & 2.32127 \mathrm{E}-04 & 0.00000 \mathrm{E}+00 & 0.00000 \mathrm{E}+00 & 0.00000 \mathrm{E}+00 & 0.00000 \mathrm{E}+000 & 0.00\end{array}$

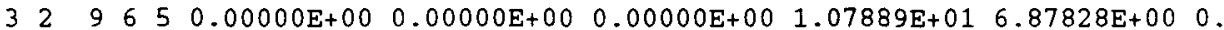

$\begin{array}{lllllllllllll}6 & 2 & 9 & 6 & 5 & 0.00000 \mathrm{E}+00 & 0.00000 \mathrm{E}+00 & 0.00000 \mathrm{E}+00 & 8.83783 \mathrm{E}+00 & 4.05125 \mathrm{E}+00 & 0.00\end{array}$

$\begin{array}{lllllllllll}3 & 2 & 911 & 5 & 1.74590 \mathrm{E}+00 & 7.88825 \mathrm{E}-01 & 1.18004 \mathrm{E}-01 & 6.53222 \mathrm{E}-02 & 2.98845 \mathrm{E}-02 & 0 .\end{array}$

$\begin{array}{lllllllllll}6 & 2 & 911 & 5 & 5.71713 \mathrm{E}-01 & 1.48171 \mathrm{E}-01 & 1.20481 \mathrm{E}-02 & 4.64449 \mathrm{E}-03 & 1.59547 \mathrm{E}-03 & 0 .\end{array}$.

$\begin{array}{lllllllllllll}3 & 2 & 916 & 1 & 9.46978 \mathrm{E}-03 & 0.00000 \mathrm{E}+00 & 0.00000 \mathrm{E}+00 & 0.00000 \mathrm{E}+00 & 0.00000 \mathrm{E}+00 & 0.00 .\end{array}$

$\begin{array}{lllllllllll}6 & 2 & 916 & 1 & 3.49686 \mathrm{E}-04 & 0.00000 \mathrm{E}+00 & 0.00000 \mathrm{E}+00 & 0.00000 E+00 & 0.00000 E+00 & 0.00\end{array}$

$\begin{array}{lllllllllllll}3 & 2 & 10 & 6 & 5 & 0.00000 E+00 & 0.00000 E+00 & 0.00000 E+00 & 0.00000 E+00 & 8.76252 E+00 & 0.0\end{array}$

$\begin{array}{llllllllllll}62 & 10 & 6 & 5 & 0.00000 E+00 & 0.00000 E+00 & 0.00000 E+00 & 0.00000 E+00 & 7.47197 E+00 & 0.0\end{array}$

$32101157.38835 E+00 \quad 3.34009 E+00 \quad 5.05943 E-012.85559 E-011.26444 E-010$.

$\begin{array}{llllllllll}6 & 2 & 1011 & 5 & 4.79023 \mathrm{E}+00 & 1.23350 \mathrm{E}+00 & 9.89043 \mathrm{E}-02 & 3.74234 \mathrm{E}-02 & 1.14299 \mathrm{E}-02 & 0 .\end{array}$ 
Listing 12. Continued.

$\begin{array}{llllllllllll}3 & 2 & 1016 & 1 & 4.00674 \mathrm{E}-02 & 0.00000 \mathrm{E}+00 & 0.00000 \mathrm{E}+00 & 0.00000 \mathrm{E}+00 & 0.00000 \mathrm{E}+00 & 0 .\end{array}$

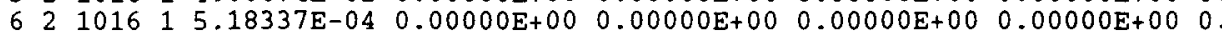

$\begin{array}{lllllllllll}3 & 2 & 1111 & 5 & 7.49276 \mathrm{E}+00 & 1.00656 \mathrm{E}+01 & 1.52546 \mathrm{E}+00 & 8.63299 \mathrm{E}-01 & 3.81077 \mathrm{E}-01 & 0 .\end{array}$

$\begin{array}{llllllllllll}6 & 2 & 1111 & 5 & 6.55419 \mathrm{E}+00 & 6.33768 \mathrm{E}+00 & 5.05704 \mathrm{E}-01 & 1.89834 \mathrm{E}-01 & 5.10829 \mathrm{E}-02 & 0\end{array}$

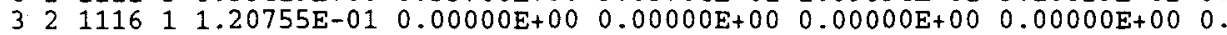

$\begin{array}{llllllllll}6 & 2 & 1116 & 1 & 5.49092 \mathrm{E}-03 & 0.00000 \mathrm{E}+00 & 0.00000 \mathrm{E}+00 & 0.00000 \mathrm{E}+00 & 0.00000 \mathrm{E}+00 & 0 .\end{array}$

$\begin{array}{lllllllll}32 & 1211 & 5 & 0.00000 \mathrm{E}+00 & 9.90305 \mathrm{E}+00 & 5.56543 \mathrm{E}+00 & 3.14947 \mathrm{E}+00 & 1.39036 \mathrm{E}+00 & 0 .\end{array}$

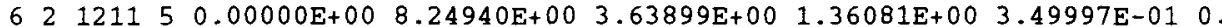

$\begin{array}{llllllllll}3 & 2 & 1216 & 1 & 4.40577 \mathrm{E}-01 & 0.00000 \mathrm{E}+00 & 0.00000 \mathrm{E}+00 & 0.00000 \mathrm{E}+00 & 0.00000 \mathrm{E}+00 & 0 .\end{array}$

$\begin{array}{lllllllllll}6 & 2 & 1216 & 1 & 4.47166 \mathrm{E}-02 & 0.00000 \mathrm{E}+00 & 0.00000 \mathrm{E}+00 & 0.00000 \mathrm{E}+00 & 0.00000 \mathrm{E}+00 & 0 .\end{array}$

$\begin{array}{lllllllllll}3 & 2 & 1311 & 5 & 0.00000 \mathrm{E}+00 & 0.00000 \mathrm{E}+00 & 6.06762 \mathrm{E}+00 & 9.09436 \mathrm{E}+00 & 4.01472 \mathrm{E}+00 & 0\end{array}$

$\begin{array}{llllllllll}6 & 2 & 1311 & 5 & 0.00000 \mathrm{E}+00 & 0.00000 \mathrm{E}+00 & 5.45304 \mathrm{E}+00 & 6.35808 \mathrm{E}+00 & 1.61894 \mathrm{E}+00 & 0 .\end{array}$

$\begin{array}{llllllllll}3 & 2 & 1316 & 1 & 1.27218 \mathrm{E}+00 & 0.00000 \mathrm{E}+00 & 0.00000 \mathrm{E}+00 & 0.00000 \mathrm{E}+00 & 0.00000 \mathrm{E}+00 & 0.0\end{array}$

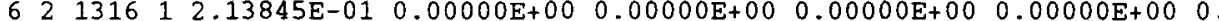

$\begin{array}{lllllllllll}3 & 2 & 1411 & 5 & 0.00000 \mathrm{E}+00 & 0.00000 \mathrm{E}+00 & 0.00000 \mathrm{E}+00 & 7.53460 \mathrm{E}+00 & 9.80683 \mathrm{E}+00 & 0 .\end{array}$

$\begin{array}{llllllllll}6 & 2 & 1411 & 5 & 0.00000 \mathrm{E}+00 & 0.00000 \mathrm{E}+00 & 0.00000 \mathrm{E}+00 & 6.58294 \mathrm{E}+00 & 6.22893 \mathrm{E}+00 & 0 .\end{array}$

$\begin{array}{llllllllll}3 & 2 & 1416 & 1 & 3.10758 \mathrm{E}+00 & 0.00000 \mathrm{E}+00 & 0.00000 \mathrm{E}+00 & 0.00000 \mathrm{E}+00 & 0.00000 \mathrm{E}+00 & 0 .\end{array}$

$\begin{array}{llllllllll}6 & 2 & 1416 & 1 & 8.32120 \mathrm{E}-01 & 0.00000 \mathrm{E}+00 & 0.00000 \mathrm{E}+00 & 0.00000 \mathrm{E}+00 & 0.00000 \mathrm{E}+00 & 0 .\end{array}$

$\begin{array}{lllllllllll}3 & 2 & 1511 & 5 & 0.00000 \mathrm{E}+00 & 0.00000 \mathrm{E}+00 & 0.00000 \mathrm{E}+00 & 2.39296 \mathrm{E}-02 & 1.61604 \mathrm{E}+01 & 0 .\end{array}$

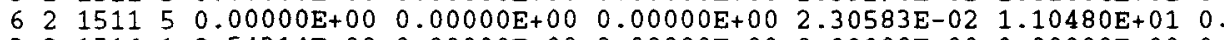

$\begin{array}{llllllllll}32 & 1516 & 1 & 8.54314 \mathrm{E}+00 & 0.00000 \mathrm{E}+00 & 0.00000 \mathrm{E}+00 & 0.00000 \mathrm{E}+00 & 0.00000 \mathrm{E}+00 & 0 .\end{array}$

$\begin{array}{llllllllll}6 & 2 & 1516 & 1 & 9.79431 \mathrm{E}-01 & 0.00000 \mathrm{E}+00 & 0.00000 \mathrm{E}+00 & 0.00000 \mathrm{E}+00 & 0.00000 \mathrm{E}+00 & 0\end{array}$

$\begin{array}{llllllllll}3 & 2 & 1611 & 5 & 0.00000 E+00 & 0.00000 E+00 & 0.00000 E+00 & 6.32213 E-06 & 1.18831 E+00 & 0 .\end{array}$

$\begin{array}{lllllllllll}6 & 2 & 1611 & 5 & 0.00000 \mathrm{E}+00 & 0.00000 \mathrm{E}+00 & 0.00000 \mathrm{E}+00 & 5.51435 \mathrm{E}-07 & 2.28547 \mathrm{E}-01 & 0 .\end{array}$

$\begin{array}{llllllllll}32 & 1616 & 1 & 4.54245 \mathrm{E}+01 & 0.00000 \mathrm{E}+00 & 0.00000 \mathrm{E}+00 & 0.00000 \mathrm{E}+00 & 0.00000 \mathrm{E}+00 & 0 .\end{array}$

$\begin{array}{lllllllllll}16 & 2 & 1616 & 1 & 2.63176 \mathrm{E}+01 & 0.00000 E+00 & 0.00000 E+00 & 0.00000 E+00 & 0.00000 E+00 & 0 .\end{array}$ $0 \begin{array}{lll}0 & 0 & 3\end{array}$ PLUTONIUM-239 VERS (FAST) + PLUTONIUM-239 VERS (THERMAL)

$\begin{array}{llllllllllll}1 & 3 & 1 & 1 & 5 & 8.46874 \mathrm{E}-02 & 6.96306 \mathrm{E}-02 & 6.69624 \mathrm{E}-02 & 5.71760 \mathrm{E}-02 & 3.83585 \mathrm{E}-02 & 0 .\end{array}$

$\begin{array}{lllllllllll}1 & 3 & 6 & 1 & 5 & 2.68659 \mathrm{E}-02 & 2.14478 \mathrm{E}-02 & 1.50743 \mathrm{E}-02 & 7.34266 \mathrm{E}-03 & 3.75016 \mathrm{E}-03 & 0\end{array}$

$\begin{array}{llllllllllll}1 & 3 & 11 & 1 & 5 & 2.08397 \mathrm{E}-03 & 6.83842 \mathrm{E}-03 & 8.94495 \mathrm{E}-03 & 1.72123 \mathrm{E}-03 & 2.62799 \mathrm{E}-04 & 0 .\end{array}$

$\begin{array}{lllllllllll}1 & 3 & 16 & 1 & 1 & 3.99705 \mathrm{E}-04 & 0.00000 \mathrm{E}+00 & 0.00000 \mathrm{E}+00 & 0.00000 \mathrm{E}+00 & 0.00000 \mathrm{E}+00 & 0 .\end{array}$

$\begin{array}{lllllllllll}1 & 3 & 1 & 2 & 5 & 1.78932 \mathrm{E}+00 & 1.94036 \mathrm{E}+00 & 1.78997 \mathrm{E}+00 & 1.70827 \mathrm{E}+00 & 1.72613 \mathrm{E}+00 & 0 .\end{array}$

$\begin{array}{lllllllllll}1 & 3 & 6 & 2 & 5 & 2.09511 \mathrm{E}+00 & 3.72755 \mathrm{E}+00 & 9.03869 \mathrm{E}+00 & 2.96685 \mathrm{E}+01 & 7.40186 \mathrm{E}+01 & 0\end{array}$

$\begin{array}{llllllllllll}1 & 3 & 11 & 2 & 5 & 1.48989 E+02 & 3.99224 E+01 & 2.74447 E+01 & 1.82520 E+02 & 1.19673 E+03 & 0 .\end{array}$

$\begin{array}{lllllllllll}1 & 3 & 16 & 2 & 1 & 9.54277 \mathrm{E}+02 & 0.00000 \mathrm{E}+00 & 0.00000 \mathrm{E}+00 & 0.00000 \mathrm{E}+00 & 0.00000 \mathrm{E}+00 & 0 .\end{array}$

$\begin{array}{llllllllllll}1 & 3 & 1 & 3 & 5 & 6.35933 \mathrm{E}+00 & 6.08649 \mathrm{E}+00 & 5.33778 \mathrm{E}+00 & 4.79561 \mathrm{E}+00 & 4.46463 \mathrm{E}+00 & 0 .\end{array}$

$\begin{array}{llllllllllllll}1 & 3 & 6 & 3 & 5 & 4.72182 \mathrm{E}+00 & 6.48117 \mathrm{E}+00 & 1.37961 \mathrm{E}+01 & 4.44853 \mathrm{E}+01 & 1.10163 \mathrm{E}+02 & 0\end{array}$

$\begin{array}{lllllllllllll}1 & 3 & 11 & 3 & 5 & 2.55754 \mathrm{E}+02 & 7.23323 \mathrm{E}+01 & 6.13873 \mathrm{E}+01 & 3.55722 \mathrm{E}+02 & 2.14995 \mathrm{E}+03 & 0 .\end{array}$

$\begin{array}{llllllllllll}1 & 3 & 16 & 3 & 1 & 1.99900 \mathrm{E}+03 & 0.00000 \mathrm{E}+00 & 0.00000 \mathrm{E}+00 & 0.00000 \mathrm{E}+00 & 0.00000 \mathrm{E}+00 & 0 .\end{array}$

$\begin{array}{lllllllllll}1 & 3 & 1 & 4 & 5 & 1.80541 \mathrm{E}+00 & 1.93166 \mathrm{E}+00 & 1.76479 \mathrm{E}+00 & 1.61989 \mathrm{E}+00 & 1.53439 \mathrm{E}+000 & 0\end{array}$

$136 \quad 6 \quad 4 \quad 5 \quad 1.63700 \mathrm{E}+00 \quad 2.25008 \mathrm{E}+00 \quad 4.79050 \mathrm{E}+00 \quad 1.54475 \mathrm{E}+01 \quad 3.82544 \mathrm{E}+010$

$\begin{array}{lllllllllllll}1 & 3 & 11 & 4 & 5 & 8.88113 \mathrm{E}+01 & 2.51176 \mathrm{E}+01 & 2.13170 \mathrm{E}+01 & 1.23525 \mathrm{E}+02 & 7.43568 \mathrm{E}+02 & 0 .\end{array}$

$\begin{array}{lllllllllllll}1 & 3 & 16 & 4 & 1 & 6.91363 \mathrm{E}+02 & 0.00000 \mathrm{E}+00 & 0.00000 \mathrm{E}+00 & 0.00000 \mathrm{E}+00 & 0.00000 \mathrm{E}+00 & 0 .\end{array}$

$\begin{array}{llllllllllll}4 & 3 & 1 & 0 & 5 & 4.00458 \mathrm{E}+00 & 4.78336 \mathrm{E}+00 & 4.97913 \mathrm{E}+00 & 5.86391 \mathrm{E}+00 & 8.76095 \mathrm{E}+00 & 0\end{array}$

$43660501.24632 \mathrm{E}+01 \quad 1.55826 \mathrm{E}+01 \quad 2.21729 \mathrm{E}+01 \quad 4.54481 \mathrm{E}+01 \quad 8.87533 \mathrm{E}+010$.

$43110051.60031 E+02 \quad 4.84627 E+01 \quad 3.72701 E+01 \quad 1.93929 E+02 \quad 1.20449 E+03 \quad 0$.

$\begin{array}{lllllllllll}4 & 3 & 16 & 0 & 1 & 9.62127 \mathrm{E}+02 & 0.00000 \mathrm{E}+00 & 0.00000 E+00 & 0.00000 E+00 & 0.00000 E+00 & 0 .\end{array}$

$\begin{array}{llllllllllll}3 & 3 & 1 & 1 & 5 & 4.78398 \mathrm{E}+00 & 2.51872 \mathrm{E}-01 & 2.84829 \mathrm{E}-01 & 3.61921 \mathrm{E}-01 & 2.06069 \mathrm{E}-01 & 0\end{array}$

$\begin{array}{lllllllllllll}6 & 3 & 1 & 1 & 5 & 3.68059 E+00 & 4.26559 E-03 & 0.00000 E+00 & 0.00000 E+00 & 0.00000 E+00 & 0 .\end{array}$

$\begin{array}{lllllllllll}3 & 3 & 1 & 6 & 5 & 1.14430 \mathrm{E}-02 & 2.98313 \mathrm{E}-07 & 0.00000 \mathrm{E}+00 & 0.00000 \mathrm{E}+00 & 0.00000 \mathrm{E}+00 & 0.0 .\end{array}$

$\begin{array}{lllllllllll}6 & 3 & 1 & 6 & 5 & 0.00000 \mathrm{E}+00 & 0.00000 \mathrm{E}+00 & 0.00000 \mathrm{E}+00 & 0.00000 \mathrm{E}+00 & 0.00000 \mathrm{E}+00 & 0 .\end{array}$

$\begin{array}{lllllllllllll}3 & 3 & 2 & 1 & 5 & 0.00000 \mathrm{E}+00 & 4.30020 \mathrm{E}+00 & 3.96271 \mathrm{E}-01 & 4.00502 \mathrm{E}-01 & 2.56277 \mathrm{E}-01 & 0 .\end{array}$

$\begin{array}{lllllllllll}6 & 3 & 2 & 1 & 5 & 0.00000 \mathrm{E}+00 & 2.52439 \mathrm{E}+00 & 2.93320 \mathrm{E}-03-1.79535 \mathrm{E}-04 & 0.00000 \mathrm{E}+00 & 0 .\end{array}$

$\begin{array}{llllllllllll}3 & 3 & 2 & 6 & 5 & 1.68921 \mathrm{E}-02 & 0.00000 \mathrm{E}+00 & 0.00000 \mathrm{E}+00 & 0.00000 \mathrm{E}+00 & 0.00000 \mathrm{E}+00 & 0 .\end{array}$

$\begin{array}{lllllllllllll}6 & 3 & 2 & 6 & 5 & 0.00000 \mathrm{E}+00 & 0.00000 \mathrm{E}+00 & 0.00000 \mathrm{E}+00 & 0.00000 \mathrm{E}+00 & 0.00000 \mathrm{E}+00 & 0.0\end{array}$

$\begin{array}{llllllllllll}3 & 3 & 3 & 5 & 0.00000 \mathrm{E}+00 & 0.00000 \mathrm{E}+00 & 4.37488 \mathrm{E}+00 & 6.92555 \mathrm{E}-01 & 2.42598 \mathrm{E}-01 & 0 .\end{array}$

$\begin{array}{llllllllll}6 & 3 & 3 & 1 & 5 & 0.00000 \mathrm{E}+00 & 0.00000 \mathrm{E}+00 & 2.11954 \mathrm{E}+00 & 9.03607 \mathrm{E}-03-1.08627 \mathrm{E}-03 & 0 .\end{array}$

$\begin{array}{llllllllllll}3 & 3 & 3 & 6 & 5 & 6.61040 \mathrm{E}-03 & 0.00000 \mathrm{E}+00 & 0.00000 \mathrm{E}+00 & 0.00000 \mathrm{E}+00 & 0.00000 \mathrm{E}+00 & 0\end{array}$

$\begin{array}{llllllllllll}6 & 3 & 3 & 6 & 5 & 0.00000 \mathrm{E}+00 & 0.00000 \mathrm{E}+00 & 0.00000 \mathrm{E}+00 & 0.00000 \mathrm{E}+00 & 0.00000 \mathrm{E}+00 & 0 .\end{array}$

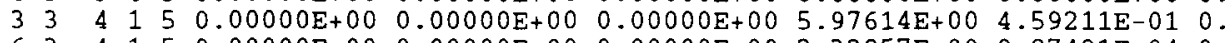

$\begin{array}{llllllllll}6 & 3 & 4 & 1 & 5 & 0.00000 \mathrm{E}+00 & 0.00000 \mathrm{E}+00 & 0.00000 \mathrm{E}+00 & 2.32857 \mathrm{E}+00-9.87491 \mathrm{E}-04 & 0 .\end{array}$

$\begin{array}{lllllllllll}3 & 3 & 4 & 6 & 5 & 4.76583 \mathrm{E}-02 & 0.00000 \mathrm{E}+00 & 0.00000 \mathrm{E}+00 & 0.00000 \mathrm{E}+00 & 0.00000 \mathrm{E}+00 & 0 .\end{array}$

$\begin{array}{lllllllllll}6 & 3 & 4 & 6 & 5-2.24539 \mathrm{E}-04 & 0.00000 \mathrm{E}+00 & 0.00000 \mathrm{E}+00 & 0.00000 \mathrm{E}+00 & 0.00000 \mathrm{E}+00 & 0 .\end{array}$

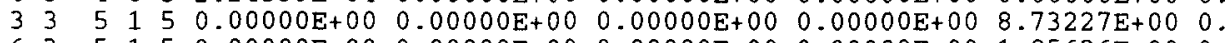

$\begin{array}{lllllllllll}6 & 3 & 5 & 1 & 5 & 0.00000 \mathrm{E}+00 & 0.00000 \mathrm{E}+00 & 0.00000 \mathrm{E}+00 & 0.00000 \mathrm{E}+00 & 1.85626 \mathrm{E}+00 & 0\end{array}$

$\begin{array}{llllllllllll}3 & 3 & 5 & 6 & 5 & 1.49904 \mathrm{E}-01 & 0.00000 \mathrm{E}+00 & 0.00000 \mathrm{E}+00 & 0.00000 \mathrm{E}+00 & 0.00000 \mathrm{E}+00 & 0 .\end{array}$

$\begin{array}{lllllllllll}6 & 3 & 5 & 6 & 5-8.89649 \mathrm{E}-03 & 0.00000 \mathrm{E}+00 & 0.00000 \mathrm{E}+00 & 0.00000 \mathrm{E}+00 & 0.00000 \mathrm{E}+00 & 0.0 .\end{array}$

$\begin{array}{llllllllllll}3 & 3 & 6 & 6 & 5 & 1.08508 \mathrm{E}+01 & 1.09157 \mathrm{E}-01 & 0.00000 \mathrm{E}+00 & 0.00000 \mathrm{E}+00 & 0.00000 \mathrm{E}+00 & 0.0 .\end{array}$

$\begin{array}{llllllllllll}6 & 3 & 6 & 6 & 5 & 6.03042 \mathrm{E}-01-1.11443 \mathrm{E}-02 & 0.00000 \mathrm{E}+00 & 0.00000 \mathrm{E}+00 & 0.00000 \mathrm{E}+00 & 0\end{array}$

$\begin{array}{lllllllllll}3 & 3 & 7 & 5 & 0.00000 \mathrm{E}+00 & 1.17761 \mathrm{E}+01 & 1.09780 \mathrm{E}-01 & 2.88850 \mathrm{E}-03 & 5.83714 \mathrm{E}-05 & 0\end{array}$

$6337650.00000 E+005.38414 E-02-2.00726 E-02-2.07126 E-06-3.32407 E-06 \quad 0$.

$\begin{array}{llllllllllll}3 & 3 & 8 & 6 & 5 & 0.00000 \mathrm{E}+00 & 0.00000 \mathrm{E}+00 & 1.30704 \mathrm{E}+01 & 1.00908 \mathrm{E}-01 & 0.00000 \mathrm{E}+00 & 0\end{array}$

$\begin{array}{llllllllllll}6 & 3 & 8 & 6 & 5 & 0.00000 \mathrm{E}+00 & 0.00000 \mathrm{E}+00 & 6.95402 \mathrm{E}-02-3.24882 \mathrm{E}-02 & 0.00000 \mathrm{E}+00 & 0 .\end{array}$

$\begin{array}{llllllllllll}3 & 3 & 9 & 6 & 5 & 0.00000 \mathrm{E}+00 & 0.00000 \mathrm{E}+00 & 0.00000 \mathrm{E}+00 & 1.57787 \mathrm{E}+01 & 4.54604 \mathrm{E}-02 & 0 .\end{array}$

$\begin{array}{llllllllll}6 & 3 & 9 & 6 & 5 & 0.00000 \mathrm{E}+00 & 0.00000 \mathrm{E}+00 & 0.00000 \mathrm{E}+00 & 5.87636 \mathrm{E}-02-1.42585 \mathrm{E}-02 & 0 .\end{array}$

$\begin{array}{lllllllllll}3 & 3 & 10 & 6 & 0.00000 \mathrm{E}+00 & 0.00000 \mathrm{E}+00 & 0.00000 \mathrm{E}+00 & 0.00000 \mathrm{E}+00 & 1.47187 \mathrm{E}+010 .\end{array}$ 
Listing 12. Continued.

$\begin{array}{llllllllllll}63 & 1065 & 0.00000 E+00 & 0.00000 E+00 & 0.00000 E+00 & 0.00000 E+00 & 6.05063 E-02 & 0 .\end{array}$

$\begin{array}{llllllllll}3 & 3 & 1011 & 5 & 5.76656 \mathrm{E}-02 & 0.00000 \mathrm{E}+00 & 0.00000 \mathrm{E}+00 & 0.00000 \mathrm{E}+00 & 0.00000 \mathrm{E}+00 & 0 .\end{array}$

$\begin{array}{llllllllll}6 & 3 & 1011 & 5-1.88986 \mathrm{E}-02 & 0.00000 \mathrm{E}+00 & 0.00000 E+00 & 0.00000 E+00 & 0.00000 \mathrm{E}+00 & 0 .\end{array}$

$\begin{array}{lllllllllll}3 & 3 & 1111 & 5 & 1.10432 \mathrm{E}+01 & 2.96321 \mathrm{E}-02 & 0.00000 \mathrm{E}+00 & 0.00000 \mathrm{E}+00 & 0.00000 \mathrm{E}+00 & 0 .\end{array}$

$\begin{array}{llllllllll}6 & 3 & 1111 & 5 & 4.09983 \mathrm{E}-02-9.85503 \mathrm{E}-03 & 0.00000 \mathrm{E}+00 & 0.00000 \mathrm{E}+00 & 0.00000 \mathrm{E}+00 & 0 .\end{array}$

$\begin{array}{llllllllll}3 & 3 & 1211 & 5 & 0.00000 \mathrm{E}+00 & 8.51153 \mathrm{E}+00 & 5.29369 \mathrm{E}-02 & 0.00000 \mathrm{E}+00 & 0.00000 \mathrm{E}+00 & 0 .\end{array}$

$\begin{array}{llllllllll}6 & 3 & 1211 & 5 & 0.00000 \mathrm{E}+00 & 4.15925 \mathrm{E}-02-1.74989 \mathrm{E}-02 & 0.00000 \mathrm{E}+00 & 0.00000 \mathrm{E}+00 & 0 .\end{array}$

$\begin{array}{llllllllll}3 & 3 & 1311 & 5 & 0.00000 \mathrm{E}+00 & 0.00000 \mathrm{E}+00 & 9.73858 \mathrm{E}+00 & 1.14577 \mathrm{E}-01 & 0.00000 \mathrm{E}+00 & 0 .\end{array}$

$\begin{array}{lllllllll}6 & 3 & 1311 & 5 & 0.00000 \mathrm{E}+00 & 0.00000 \mathrm{E}+00 & 6.56671 \mathrm{E}-02-3.79508 \mathrm{E}-02 & 0.00000 \mathrm{E}+00 & 0 .\end{array}$

$\begin{array}{llllllllll}3 & 3 & 1411 & 5 & 0.00000 \mathrm{E}+00 & 0.00000 \mathrm{E}+00 & 0.00000 \mathrm{E}+00 & 1.13162 \mathrm{E}+01 & 1.23996 \mathrm{E}-01 & 0 .\end{array}$

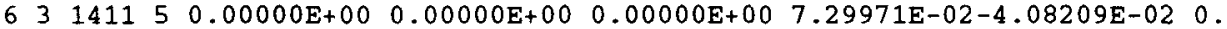

$\begin{array}{llllllllll}3 & 3 & 1511 & 5 & 0.00000 \mathrm{E}+00 & 0.00000 \mathrm{E}+00 & 0.00000 \mathrm{E}+00 & 0.00000 \mathrm{E}+00 & 7.78186 \mathrm{E}+00 & 0 .\end{array}$

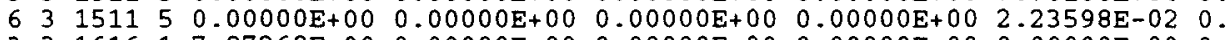

$\begin{array}{lllllllllll}3 & 3 & 1616 & 1 & 7.87268 \mathrm{E}+00 & 0.00000 \mathrm{E}+00 & 0.00000 \mathrm{E}+00 & 0.00000 \mathrm{E}+00 & 0.00000 \mathrm{E}+00 & 0 .\end{array}$

$\begin{array}{llllllllll}163161612.20415 E-02 & 0.00000 E+00 & 0.00000 E+00 & 0.00000 E+00 & 0.00000 E+00 & 0 .\end{array}$ 
Lieting 13. Table 1 Case 3, scupp tnput using Bansen-Ronch crose wections.

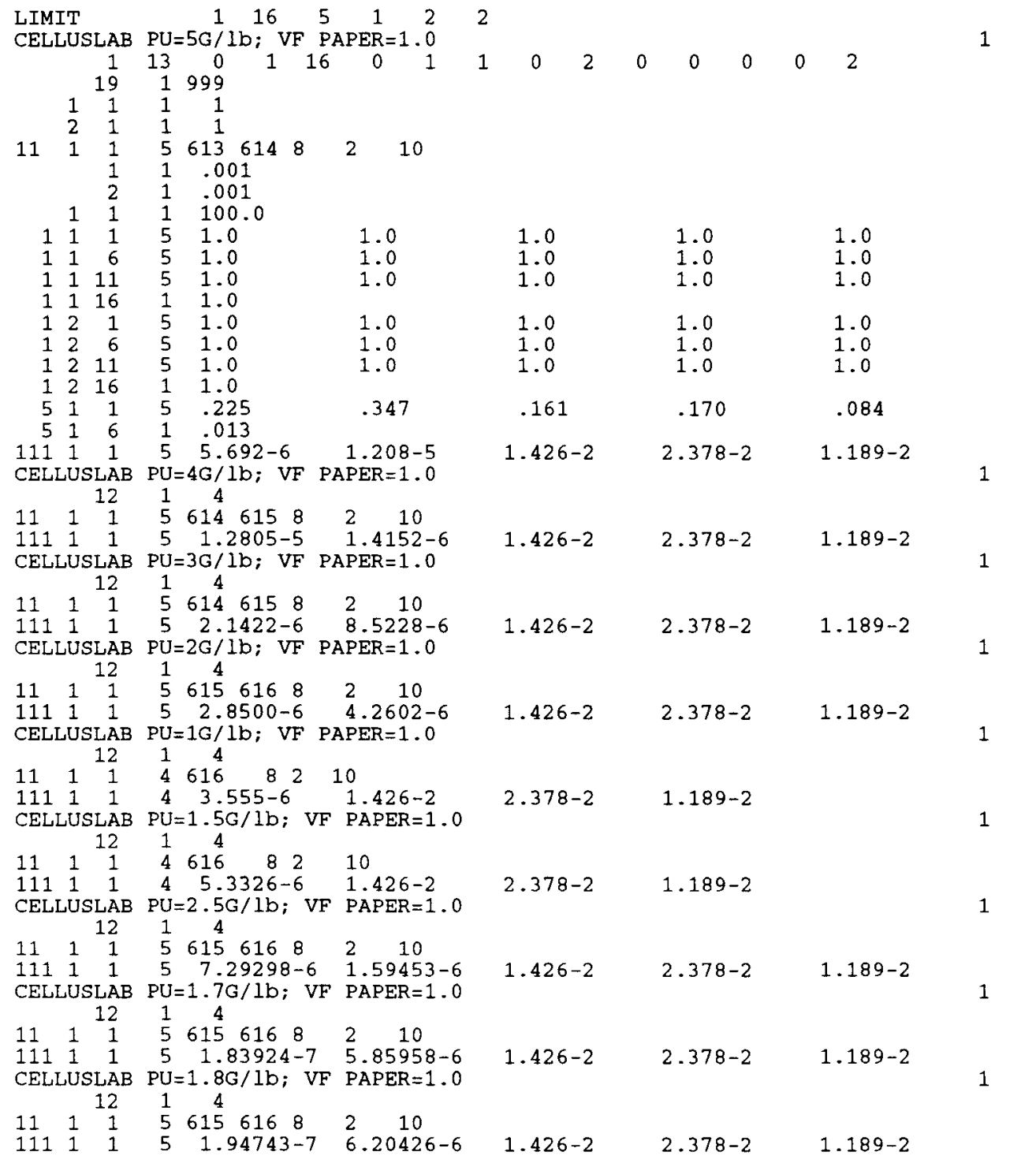


Listing 14. Table 1 Case 3, KGNO-V.a input using Bansen-Roach cross sections.

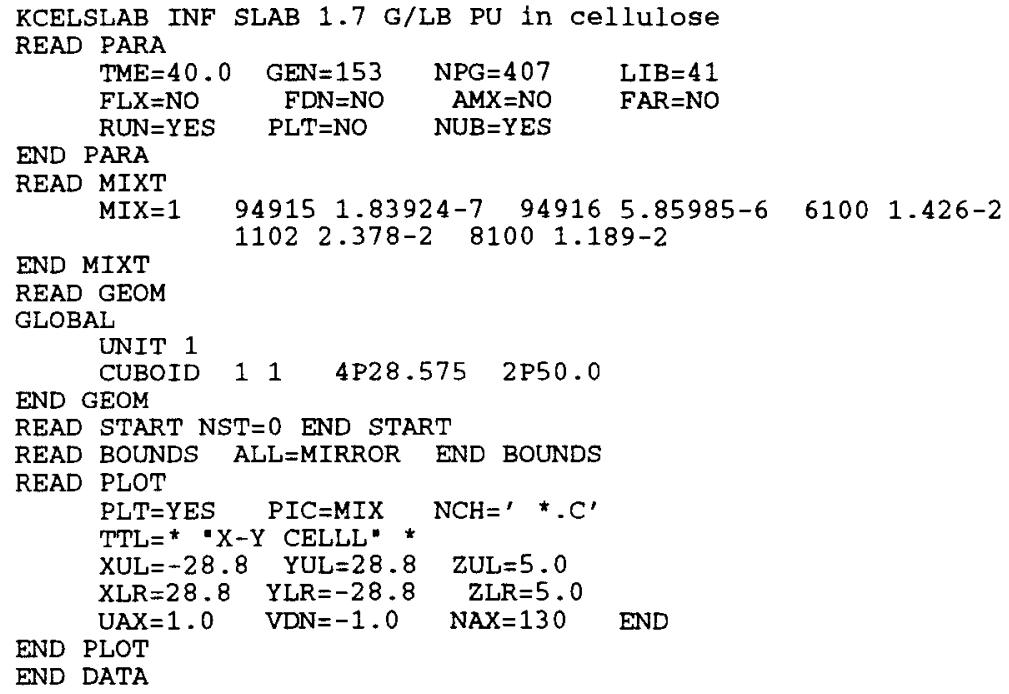

Listing 15. Table 1 Case 3, KBNo-V.a input using csis and 27-group cross sections. 
Listing 17. Table 1 Case 4, scMMP Input using Bansen-Roach cross sections.

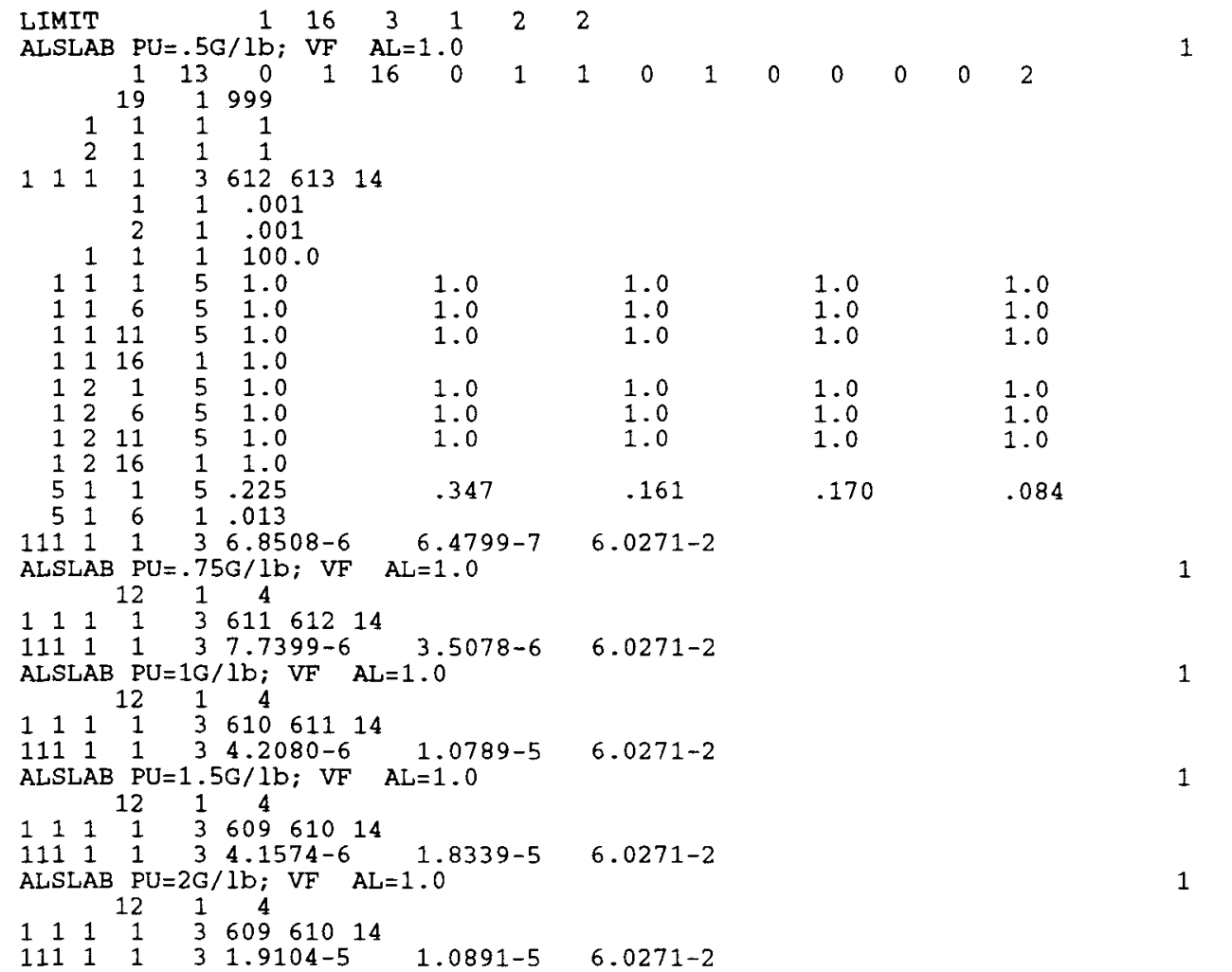

Listing 18. Table 1 Case 4, KBNO-V.a input using Bansen-Roach cross sections.

KAMSLAB INF SLAB $1.25 \mathrm{G} / \mathrm{LB}$ PU in aluminum

READ PARA

$T M E=40.0 \quad G E N=153 \quad N P G=407 \quad L I B=41$

FLX $=$ NO $\quad F D N=N O \quad A M X=N O \quad F A R=N O$

END PARA

RUN $=$ YES $\quad P L T=N O \quad N U B=Y E S$

READ $\underset{M I X T}{M I X=1}$

MIX=1 $94910 \quad 1.5432-5 \quad 94911 \quad 3.3154-6 \quad 13100 \quad 6.0271-2$

ND MIXT

READ GEOM

GLOBAL

UNIT 1

CUBOID $1114 \mathrm{P} 28.575 \quad 2 \mathrm{P} 50.0$

END GEOM

READ START NST $=0$ END START

READ BOUNDS ALL=MIRROR END BOUNDS

READ PLOT

PLT $=$ YES PIC $=\mathrm{MIX} \quad \mathrm{NCH}=$ ' *. $\mathrm{C}^{\prime}$

TTL $=$ * 'X X CELLL' *

$\mathrm{XUL}=-28.8 \quad \mathrm{YUL}=28.8 \quad \mathrm{ZUL}=5.0$

$X L R=28.8 \quad Y L R=-28.8 \quad$ ZLR $=5.0$

END PLOT

$\mathrm{UAX}=1.0 \quad \mathrm{VDN}=-1.0 \quad \mathrm{NAX}=130 \quad$ END

END DATA 
Listing 19. Table 1 Case 4, KBNO-V.a Input using csis and 27-group crose sections.

$=$ CSAS 25

CAMSLAB $1.25 \mathrm{~g}$ Pu $/ \mathrm{lb}$ aluminum

27GROUPNDF4 INFHOMMEDIUM

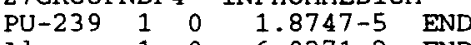

Al $11006.0271-2$ END

END COMP

KAMSLAB INF SLAB $1.25 \mathrm{G} / \mathrm{LB}$ PU in aluminum

READ PARA

$T M E=40.0 \quad G E N=153 \quad N P G=407$

FLX $=$ NO $\quad \mathrm{FDN}=\mathrm{NO} \quad \mathrm{AMX}=\mathrm{NO} \quad \mathrm{FAR}=\mathrm{NO}$

END PARA

RUN=YES PLT $=$ NO NUB $=$ YES

READ GEOM

GLOBAL

UNIT 1

END GEOM

CUBOID 1114 4P28.575 2P50.0

READ START NST=0 END START

READ BOUNDS ALL=MIRROR END BOUNDS

READ PLOT

PLT $=$ YES PIC=MIX NCH=' *. $\mathrm{C}^{\prime}$

TTTL $=$ * *X-Y CELLL' *

$X U L=-28.8 \quad Y U L=28.8 \quad Z U L=5.0$

$\mathrm{XLR}=28.8 \quad \mathrm{YLR}=-28.8 \quad \mathrm{ZLR}=5.0$

END PLO'T

$\mathrm{UAX}=1.0 \quad \mathrm{VDN}=-1.0 \quad \mathrm{NAX}=130 \quad$ END

END DATA

Listing 20. Table 1 Case 4, MCNP input.

MAMSLAB INF SLAB 1.25 G/LB PU IN ALUMINUM

$1 \quad \begin{array}{lllllllll}1 & 6.02897474 \mathrm{e}-2 & -1 & 2 & -3 & 4 & -5 & 6 & \text { imp: } n=1\end{array}$ \$slab

*1 px 28.575 sasterisk means reflecting surface

$\star 2 \quad \mathrm{px}-28.575$

$* 3$ py 28.575

*4 py -28.575

$* 5 \quad$ pz 50.0

kcode $1000120145 \quad 50000 \quad \$ n p g=1000, \quad n s k=20$ gen $=145$

sdef cel $=1$ \$starting source in cell 1

$\begin{array}{llll}\text { print } & 94239.50 \mathrm{c} & 1.87474 \mathrm{e}-5 & 13027.50 \mathrm{c} \quad 6.0271 \mathrm{e}-2\end{array}$ 
Listing 21. Table 1 Case 5, scukp input uaing Hansen-Roach crose sectlons.

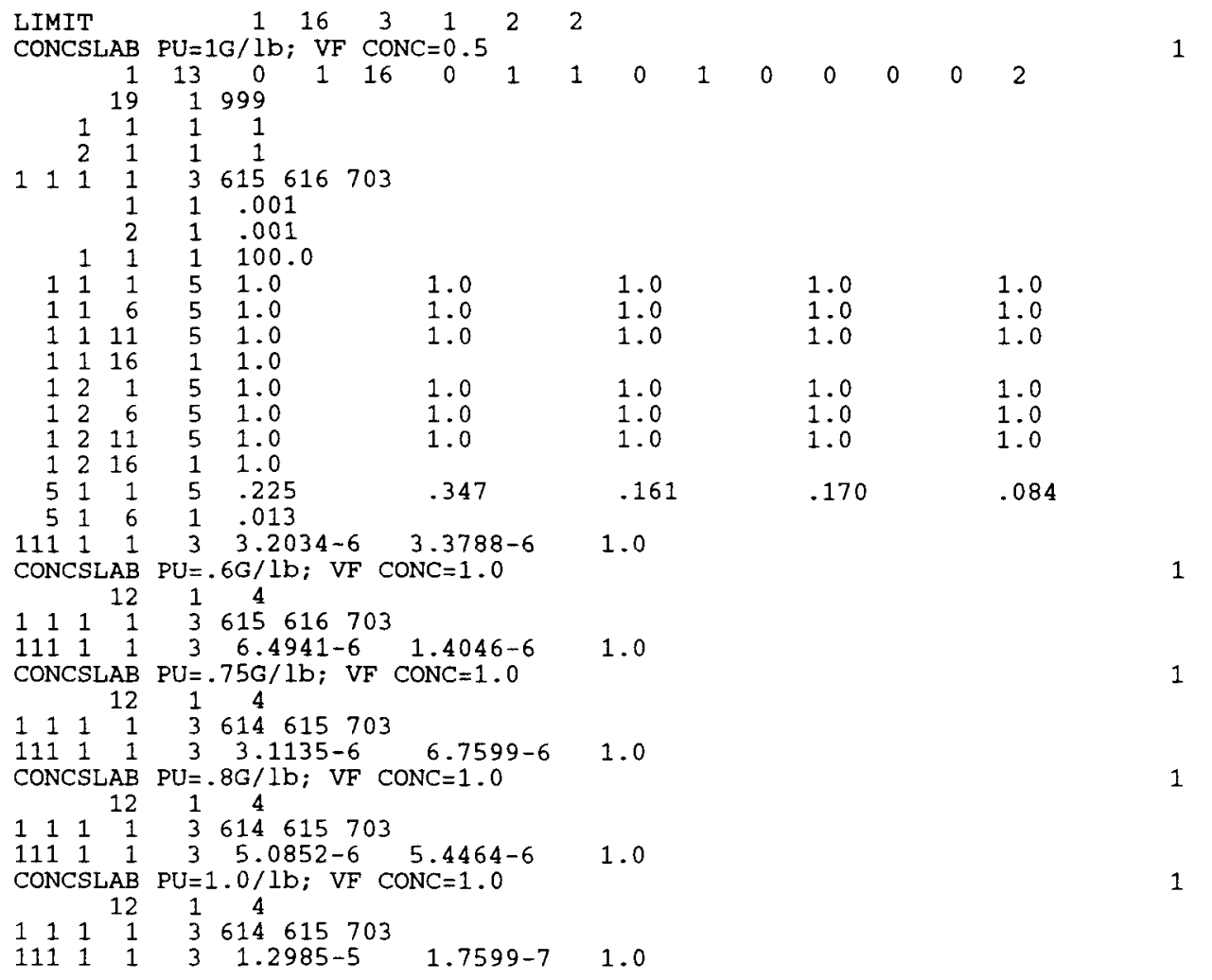

Listing 22. Table 1 Case 5, KRNO-V.a input using Hansen-Roach crons mections.

KCONSLAB INF SLAB $0.75 \mathrm{G} / \mathrm{LB}$ PU in concrete

READ PARA

TME $=40.0 \quad$ GEN $=153 \quad \mathrm{NPG}=407 \quad \mathrm{LIB}=41$

$F L X=N O \quad F D N=N O \quad A M X=N O \quad F A R=N O$

END PARA

RUN=YES PLT=NO NUB=YES

READ MIXT

END MIXT

MIX $=1 \quad 94914 \quad 3.1135-6 \quad 94915 \quad 6.7599-6 \quad 301 \quad 1.0$

READ GEOM

GLOBAL

UNIT 1

CUBOID 1114 4P28.575 2P50.0

END GEOM

READ START NST $=0$ END START

READ BOUNDS ALL=MIRROR END BOUNDS

READ PLOT

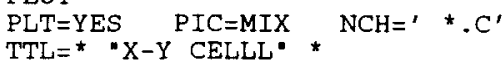

XUL $=-28.8 \quad$ YUL $=28.8 \quad$ ZUL $=5.0$

$\mathrm{XLR}=28.8 \quad \mathrm{YLR}=-28.8 \quad \mathrm{ZLR}=5.0$

END PLOT

$\mathrm{UAX}=1.0 \quad \mathrm{VDN}=-1.0 \quad \mathrm{NAX}=130 \quad$ END

END DATA 
Lleting 23. Table 1 case 5, krNO-V.a Input using csAs and 27-group cross eactions.

$=\operatorname{CSAS} 25$

CCONSLAB INF SLAB $0.75 \mathrm{G} / \mathrm{LB}$ PU in concrete

27GROUPNDF4 INFHOMMEDIUM

PU-239 $100 \quad 9.8734-6$ (NDD

$\begin{array}{lllll}H & 1 & 0 & 0.014868 & \text { END } \\ C & 1 & 0 & 0.003814 & \text { END }\end{array}$

$0 \quad 1 \quad 000.041519 \quad$ END

$\begin{array}{lllll}\text { CA } & 1 & 0 & 0.011588 \quad \text { END }\end{array}$

SI $1100.006037 \quad$ END

FE $1100.0001968 \quad$ END

AL $1100.000735 \quad$ END

$\begin{array}{lllll}\text { NA } & 1 & 0 & 0.000304 & \text { END } \\ \text { MG } & 1 & 0 & 0.000587 & \text { END }\end{array}$

KCONSLAB INF SLAB $0.75 \mathrm{G} / \mathrm{LB}$ PU in concrete

READ PARA

TME $=40.0 \quad$ GEN $=153 \quad$ NPG $=407$

$\mathrm{FLX}=\mathrm{NO} \quad \mathrm{FDN}=\mathrm{NO} \quad \mathrm{AMX}=\mathrm{NO} \quad \mathrm{FAR}=\mathrm{NO}$

END PARA

RUN=YES PLT=NO NUB=YES

READ GEOM

GLOBAL

UNIT 1

CUBOID 114 P $28.575 \quad 2$ P 50.0

END GEOM

READ START NST $=0$ END START

READ BOUNDS ALL=MIRROR END BOUNDS

READ PLOT

PLT $=$ YES PIC $=$ MIX $\mathrm{NCH}=$ ' *. $\mathrm{C}^{\prime}$

TTL $=$ * "X-Y CELLL" *

XUL $=-28.8 \quad$ YUL $=28.8 \quad \mathrm{ZUL}=5.0$

$X L R=28.8 \quad Y L R=-28.8 \quad Z L R=5.0$

END PLOT

$\mathrm{UAX}=1.0 \quad \mathrm{VDN}=-1.0 \quad \mathrm{NAX}=130 \quad$ END

Listing 24. Table 1 Case 5, MCNP input.

MHCSLAB INF SLAB $0.75 \mathrm{G} / \mathrm{LB}$ PU IN CONCRETE (KENO/H-R)

$1 \quad 17.96586734 \mathrm{e}-2 \quad-1 \quad 2 \quad-3 \quad 4 \quad-5 \quad 6 \quad$ imp:n=1 \$slab

*1 px 28.575 sasterisk means reflecting surface

$\star 2 \quad \mathrm{px}-28.575$

$* 3$ py 28.575

* 4 py -28.575

$* 5 \quad \mathrm{pz} \quad 50.0$

kcode $100012014550000 \quad \$ n p g=1000, n s k=20$ gen $=145$

sdef cel=1 \$starting source in cell 1

print

$\begin{array}{lllll}\text { print } & 94239.50 \mathrm{C} & 9.8734 \mathrm{e}-6 & 13027.50 \mathrm{c} & 0.000735\end{array}$

$\begin{array}{llllllll}8016.50 \mathrm{c} & 0.041519 & 1001.50 \mathrm{c} & .014868 & 20000.50 \mathrm{c} & .011588\end{array}$

$\begin{array}{llllllll}14000.50 \mathrm{C} & 0.006037 & 26000.50 \mathrm{c} & 0.0001968 & 11023.50 \mathrm{c} & 0.000304\end{array}$

$6000.50 \mathrm{c} .003814 \quad 12000.50 \mathrm{c} \cdot .000587$ 
Ifsting 25. Table 1 case 6, scnup lnput using Bansen-Roach cross sections.

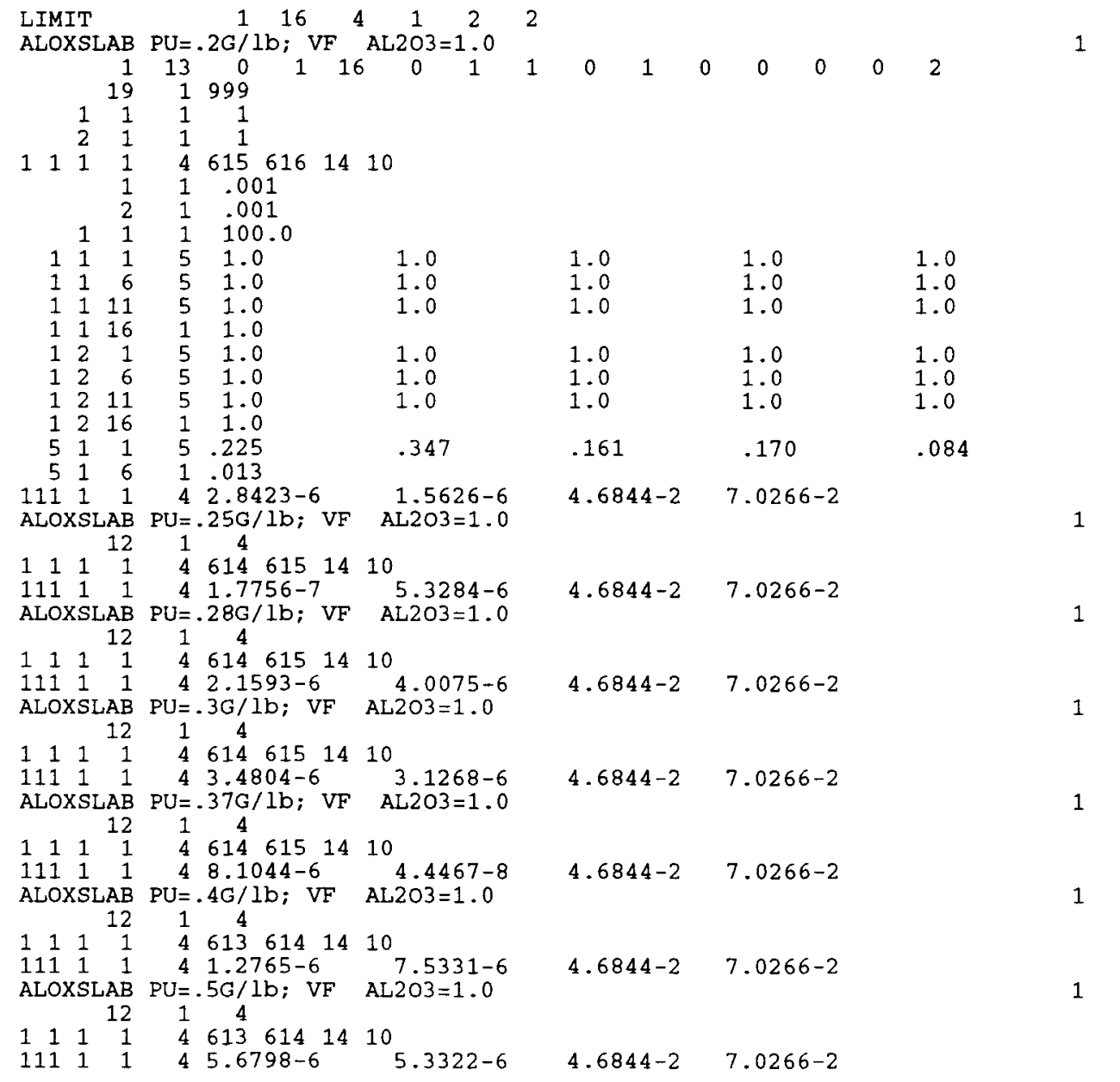

Llsting 26. Table 1 Case 6, KENO-V.a Input using Hansen-Roach cross sections.

KAOXSLAB INF SLAB $0.37 \mathrm{G} / \mathrm{LB}$ PU in aluminum oxide

READ PARA

$\begin{array}{lrrr}\text { TME }=40.0 & \text { GEN }=153 & \text { NPG }=407 & \text { LIB }=41 \\ \text { FLX }=\text { NO } & \text { FDN }=\text { NO } & \text { AMX }=\text { NO } & \text { FAR }=\text { NO }\end{array}$

END PARA

$A M X=N O \quad F A R=N O$

READ MIXT

$M I X=1 \quad 94914 \quad 8.1044-6 \quad 94915 \quad 4.4467-8 \quad 13100 \quad 4.6844-2 \quad 8100 \quad 7.0266-2$

END MIXT

READ GEOM

GLOBAL

UNIT 1

END GEOM

CUBOID 1114 P28.575 2 P50.0

READ START NST $=0$ END START

READ BOUNDS ALL=MIRROR END BOUNDS

READ PLOT

PLT $=$ YES PIC $=$ MIX $\mathrm{NCH}={ }^{\prime} * \mathrm{C}^{\prime}$

TTL $=$ * "X $Y$ CELLL" *

$\mathrm{XUL}=-28.8 \quad \mathrm{YUL}=28.8 \quad \mathrm{ZUL}=5.0$

$\mathrm{XLR}=28.8 \quad \mathrm{YLR}=-28.8 \quad \mathrm{ZLR}=5.0$

END PLOT

$\mathrm{UAX}=1.0 \quad \mathrm{VDN}=-1.0 \quad \mathrm{NAX}=130 \quad$ END

END DATA 
$=\operatorname{CSAS} 25$

CAOXSLAB $0.37 \mathrm{Pu} / \mathrm{lb}$ aluminum oxide

27GROUPNDF 4 INFHOMMEDIUM

$\begin{array}{lllll}\mathrm{PU}-239 & 1 & 0 & 8.1489-6 & \text { END } \\ \mathrm{Al} & 1 & 0 & 4.6844-2 & \text { END }\end{array}$

$\begin{array}{lllll}\text { Al } & 1 & 0 & 4.6844-2 & \text { END } \\ 0 & 1 & 0 & 7.0266-2 & \text { END }\end{array}$

END COMP

KAOXSLAB INF SLAB $0.37 \mathrm{G} / \mathrm{LB}$ PU in aluminum oxide

READ PARA

$\begin{array}{lrrr}\text { TME }=40.0 & \text { GEN }=153 & \text { NPG }=407 & \\ \text { FLX }=\text { NO } & \text { FDN=NO } & \text { AMX=NO } & \text { FAR=NO } \\ \text { RUN=YES } & \text { PLT }=\text { NO } & \text { NUB }=\text { YES } & \\ \text { PARA } & & & \end{array}$

END PARA

READ GEOM

GLOBAL

UNIT 1

END GEOM

CUBOID 1114 P $28.575 \quad 2$ P50.0

READ START NST $=0$ END START

READ BOUNDS ALL=MIRROR END BOUNDS

READ PLOT

PLT=YES PIC $=$ MIX NCH $=$ ' * $C^{\prime}$

TTL $=$ * "X-Y CELLL" *

$\mathrm{XUL}=-28.8 \quad \mathrm{YUL}=28.8 \quad \mathrm{ZUL}=5.0$

$\mathrm{XLR}=28.8 \quad \mathrm{YLR}=-28.8 \quad \mathrm{ZLR}=5.0$

END PLOT

$\mathrm{UAX}=1.0 \quad \mathrm{VDN}=-1.0 \quad \mathrm{NAX}=130^{\circ} \quad$ END

END DATA

Iisting 28. Table 1 Case 6, uCNP input.

MAOSLAB INF SLAB $0.37 \mathrm{G} / \mathrm{LB}$ PU IN ALUMINUM OXIDE

$1 \quad 1 \quad 1.17118148867 e-1 \quad-1 \quad 2 \quad-3 \quad 4 \quad-5 \quad 6 \quad$ imp:n=1 \$slab

*1 px 28.575 \$asterisk means reflecting surface

*2 px -28.575

*3 py 28.575

*4 py -28.575

$\begin{array}{lll}\star 5 & \text { pz } & 50.0 \\ \star 6 & \text { pz } & -50.0\end{array}$

kcode $100012014550000 \quad \$ n p g=1000, n s k=20 \quad$ gen $=145$

sdef cel=1 \$starting source in cell 1

print

m1 $94239.50 \mathrm{c} \quad 8.148867 \mathrm{e}-6 \quad 13027.50 \mathrm{c} \quad 4.6844 \mathrm{e}-2$

$8016.50 \mathrm{C} \quad 7.0266 \mathrm{e}-2$

Listing 29. Table 1 Case 6, combIrs 1nput.

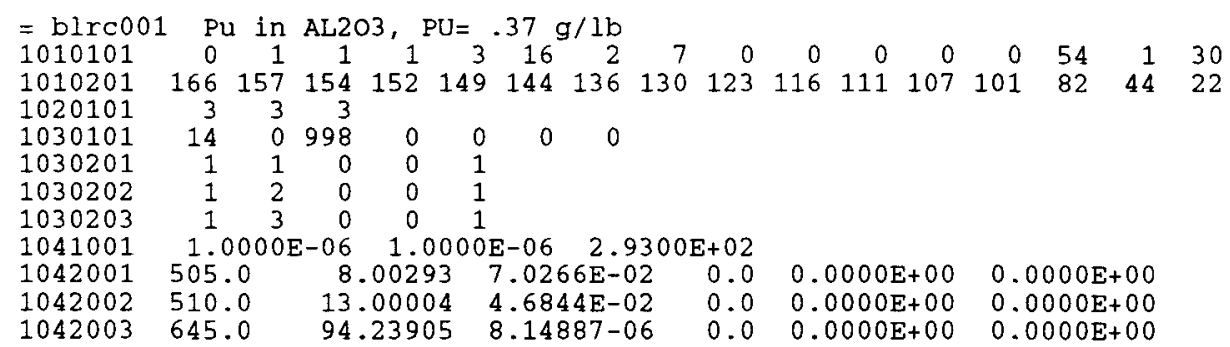


L1sting 30. Table 1 case 6, scAup input with coMBINB generated cross sections.

LIMIT
ALCOM16

$\begin{array}{rrrrrrrrr}5 & 1 & 1 & 5 & 2.55974 \mathrm{E}-01 & 3.48185 \mathrm{E}-01 & 1.71622 \mathrm{E}-01 & 1.39795 \mathrm{E}-01 & 7.01995 \mathrm{E}-02\end{array}$

$\begin{array}{llllllllll}5 & 1 & 6 & 5 & 1.34929 \mathrm{E}-02 & 6.54148 \mathrm{E}-04 & 7.17970 \mathrm{E}-05 & 5.20614 \mathrm{E}-06 & 3.44291 \mathrm{E}-07\end{array}$

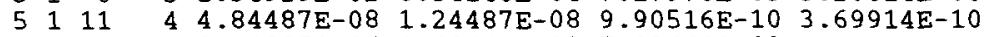

$\begin{array}{lllllll}111 & 1 & 1 & 3 & 8.148870-06 & 4.684400-02 & 7.026600-02\end{array}$

0 0 11 OXYGEN-16 VERS 5 (FAST) + OXYGEN 293K FREE GAS (THERMAL)

$\begin{array}{llllllllllll}1 & 1 & 1 & 5 & 2.63334 \mathrm{E}-01 & 2.64069 \mathrm{E}-01 & 9.13996 \mathrm{E}-02 & 1.12207 \mathrm{E}-01 & 8.36516 \mathrm{E}-02 & 0\end{array}$

$\begin{array}{lllllllllll}1 & 1 & 6 & 1 & 5 & 9.43623 \mathrm{E}-02 & 9.29318 \mathrm{E}-02 & 9.28946 \mathrm{E}-02 & 9.28137 \mathrm{E}-02 & 9.26112 \mathrm{E}-02 & 0 .\end{array}$

$\begin{array}{llllllllllll}1 & 1 & 11 & 1 & 5 & 9.28413 \mathrm{E}-02 & 9.27295 \mathrm{E}-02 & 9.26654 \mathrm{E}-02 & 9.23394 \mathrm{E}-02 & 8.96236 \mathrm{E}-02 & 0 .\end{array}$

$\begin{array}{llllllllllll}1 & 1 & 16 & 1 & 1 & 8.85972 \mathrm{E}-02 & 0.00000 \mathrm{E}+00 & 0.00000 \mathrm{E}+00 & 0.00000 \mathrm{E}+00 & 0.00000 \mathrm{E}+00 & 0.0\end{array}$

$\begin{array}{lllllllllll}1 & 1 & 1 & 2 & 5 & 3.40840 \mathrm{E}-02 & 2.20520 \mathrm{E}-08 & 2.76976 \mathrm{E}-08 & 3.70282 \mathrm{E}-08 & 6.32470 \mathrm{E}-08 & 0 .\end{array}$

$\begin{array}{llllllllllllll}1 & 1 & 6 & 2 & 5 & 1.52465 \mathrm{E}-07 & 3.42509 \mathrm{E}-07 & 7.80789 \mathrm{E}-07 & 1.87179 \mathrm{E}-06 & 3.88178 \mathrm{E}-06 & 0\end{array}$

$\begin{array}{lllllllllllll}1 & 1 & 11 & 2 & 5 & 6.82728 \mathrm{E}-06 & 1.27306 \mathrm{E}-05 & 2.22330 \mathrm{E}-05 & 3.44602 \mathrm{E}-05 & 6.35669 \mathrm{E}-05 & 0 .\end{array}$

$11162211.42812 \mathrm{E}-04 \quad 0.00000 \mathrm{E}+000000000 \mathrm{E}+00 \quad 0.00000 \mathrm{E}+00 \quad 0.00000 \mathrm{E}+000$.

$41110051.47432 \mathrm{E}+00 \quad 1.45927 \mathrm{E}+00 \quad 3.74808 \mathrm{E}+00 \quad 3.43973 \mathrm{E}+00 \quad 4.01535 \mathrm{E}+00 \quad 0$.

$41 \quad 6 \quad 0 \quad 5 \quad 3.55890 \mathrm{E}+00 \quad 3.57563 \mathrm{E}+00 \quad 3.58742 \mathrm{E}+00 \quad 3.58987 \mathrm{E}+00 \quad 3.59041 \mathrm{E}+00 \quad 0$

$411110053.59052 E+00 \quad 3.59052 E+00 \quad 3.59053 E+00 \quad 3.59057 E+00 \quad 3.62300 E+00 \quad 0$

$41160013.69651 \mathrm{E}+00 \quad 0.00000 \mathrm{E}+00 \quad 0.00000 \mathrm{E}+00 \quad 0.00000 \mathrm{E}+00 \quad 0.00000 \mathrm{E}+000$.

$\begin{array}{lllllllllll}3 & 1 & 1 & 5 & 1.58216 \mathrm{E}+00 & 3.84998 \mathrm{E}-01 & 2.69085 \mathrm{E}-03 & 2.35068 \mathrm{E}-03 & 7.97236 \mathrm{E}-04 & 0 .\end{array}$

$6111156.76516 \mathrm{E}-01-1.44253 \mathrm{E}-01$ 6.87530E-04-2.48563E-05-1.31321E-04 0

$\begin{array}{lllllllllll}3 & 1 & 1 & 6 & 5 & 2.43051 \mathrm{E}-05 & 0.00000 \mathrm{E}+00 & 0.00000 \mathrm{E}+00 & 0.00000 \mathrm{E}+00 & 0.00000 \mathrm{E}+000 . & 0.000\end{array}$

$\begin{array}{lllllllll}6 & 1 & 6 & 5-1.01821 \mathrm{E}-05 & 0.00000 \mathrm{E}+00 & 0.00000 \mathrm{E}+00 & 0.00000 \mathrm{E}+00 & 0.00000 \mathrm{E}+000 . & 0.000\end{array}$

$31221150.00000 E+00 \quad 1.20257 E+00 \quad 3.70891 E-01 \quad 0.00000 E+00 \quad 0.00000 E+00 \quad 0$.

$\begin{array}{llllllllllll}6 & 1 & 2 & 1 & 5 & 0.00000 \mathrm{E}+00 & 2.00672 \mathrm{E}-01-8.64833 \mathrm{E}-02 & 0.00000 \mathrm{E}+00 & 0.00000 \mathrm{E}+00 & 0\end{array}$

$\begin{array}{llllllllllll}3 & 1 & 3 & 1 & 5 & 0.00000 E+00 & 0.00000 E+00 & 2.81357 E+00 & 1.04774 E+00 & 0.00000 E+00 & 0.0 .\end{array}$

$613150.00000 \mathrm{E}+00 \quad 0.00000 \mathrm{E}+00 \quad 4.72860 \mathrm{E}-01-3.59629 \mathrm{E}-010.00000 \mathrm{E}+000$.

$\begin{array}{llllllllllllll}3 & 4 & 1 & 5 & 0.00000 E+00 & 0.00000 E+00 & 0.00000 E+00 & 3.50060 E+00 & 6.72785 E-01 & 0.0\end{array}$

$6144150.00000 \mathrm{E}+00 \quad 0.00000 \mathrm{E}+00 \quad 0.00000 \mathrm{E}+00 \quad 8.93923 \mathrm{E}-01-1.60268 \mathrm{E}-010$

$31151150.00000 \mathrm{E}+00 \quad 0.00000 \mathrm{E}+000.00000 \mathrm{E}+000.00000 \mathrm{E}+00 \quad 3.17792 \mathrm{E}+000$.

$\begin{array}{lllllllllll}6 & 5 & 1 & 5 & 0.00000 \mathrm{E}+00 & 0.00000 \mathrm{E}+00 & 0.00000 \mathrm{E}+00 & 0.00000 \mathrm{E}+00-2.56367 \mathrm{E}-01 & 0.00 .\end{array}$

$31156561.14442 \mathrm{E}-01 \quad 0.00000 \mathrm{E}+00 \quad 0.00000 \mathrm{E}+00 \quad 0.00000 \mathrm{E}+00 \quad 0.00000 \mathrm{E}+00 \quad 0$

$\begin{array}{llllllllllll}6 & 5 & 6 & 5-1.66624 \mathrm{E}-01 & 0.00000 \mathrm{E}+00 & 0.00000 \mathrm{E}+00 & 0.00000 \mathrm{E}+00 & 0.00000 \mathrm{E}+00 & 0.0 .\end{array}$

$\begin{array}{llllllllllll}3 & 1 & 6 & 6 & 5 & 3.38938 \mathrm{E}+00 & 2.78034 \mathrm{E}-01 & 0.00000 \mathrm{E}+00 & 0.00000 \mathrm{E}+00 & 0.00000 \mathrm{E}+00 & 0.0 .\end{array}$

$\begin{array}{lllllllllllll}6 & 6 & 6 & 5 & 2.11713 \mathrm{E}-01-1.03199 \mathrm{E}-01 & 0.00000 \mathrm{E}+00 & 0.00000 \mathrm{E}+00 & 0.00000 \mathrm{E}+00 & 0\end{array}$

$31176550.00000 \mathrm{E}+00 \quad 3.42722 \mathrm{E}+00 \quad 3.05314 \mathrm{E}-01 \quad 0.00000 \mathrm{E}+00 \quad 0.00000 \mathrm{E}+000$

$\begin{array}{lllllllllll}6 & 1 & 6 & 5 & 0.00000 \mathrm{E}+00 & 2.51449 \mathrm{E}-01-9.45390 \mathrm{E}-02 & 0.00000 \mathrm{E}+00 & 0.00000 \mathrm{E}+00 & 0.00\end{array}$

$\begin{array}{llllllllllll}3 & 1 & 8 & 6 & 5 & 0.00000 \mathrm{E}+00 & 0.00000 \mathrm{E}+00 & 3.48754 \mathrm{E}+00 & 2.57314 \mathrm{E}-01 & 0.00000 \mathrm{E}+00 & 0.0 .\end{array}$

$\begin{array}{llllllllllll}6 & 8 & 6 & 5 & 0.00000 \mathrm{E}+00 & 0.00000 \mathrm{E}+00 & 2.35938 \mathrm{E}-01-7.85051 \mathrm{E}-02 & 0.00000 \mathrm{E}+00 & 0\end{array}$

$3196650.00000 \mathrm{E}+00 \quad 0.00000 \mathrm{E}+00 \quad 0.00000 \mathrm{E}+00 \quad 3.49125 \mathrm{E}+00 \quad 2.56153 \mathrm{E}-010$.

$\begin{array}{llllllllll}6 & 9 & 6 & 5 & 0.00000 \mathrm{E}+00 & 0.00000 \mathrm{E}+00 & 0.00000 \mathrm{E}+00 & 2.35691 \mathrm{E}-01-7.81508 \mathrm{E}-02 & 0 .\end{array}$

$\begin{array}{lllllllllllll}3 & 1 & 6 & 5 & 0.00000 \mathrm{E}+00 & 0.00000 \mathrm{E}+00 & 0.00000 \mathrm{E}+00 & 0.00000 \mathrm{E}+00 & 3.38173 \mathrm{E}+00 & 0.0 .\end{array}$

$\begin{array}{lllllllllllllllll}6 & 1 & 10 & 6 & 5 & 0.00000 E+00 & 0.00000 E+00 & 0.00000 E+00 & 0.00000 E+00 & 2.62473 E-01 & 0\end{array}$

$\begin{array}{llllllllll}3 & 1 & 1011 & 5 & 3.66243 \mathrm{E}-01 & 0.00000 \mathrm{E}+00 & 0.00000 \mathrm{E}+00 & 0.00000 \mathrm{E}+00 & 0.00000 \mathrm{E}+00 & 0 .\end{array}$

$\begin{array}{llllllllll}6 & 1 & 1011 & 5-1.04909 E-01 & 0.00000 E+00 & 0.00000 E+00 & 0.00000 E+00 & 0.00000 E+00 & 0.000\end{array}$

$\begin{array}{lllllllllllll}3 & 1 & 1111 & 5 & 3.29601 \mathrm{E}+00 & 4.52065 \mathrm{E}-01 & 0.00000 E+00 & 0.00000 E+00 & 0.00000 E+00 & 0\end{array}$

$\begin{array}{llllllllllll}6 & 1 & 1111 & 5 & 2.94731 \mathrm{E}-01-1.37163 \mathrm{E}-01 & 0.00000 \mathrm{E}+00 & 0.00000 \mathrm{E}+00 & 0.00000 \mathrm{E}+00 & 0\end{array}$

$\begin{array}{llllllllll}3 & 1211 & 5 & 0.00000 E+00 & 3.46294 \mathrm{E}+00 & 2.85134 \mathrm{E}-01 & 0.00000 E+00 & 0.00000 \mathrm{E}+00 & 0\end{array}$

$\begin{array}{llllllllll}6 & 1 & 1211 & 5 & 0.00000 \mathrm{E}+00 & 2.44479 \mathrm{E}-01-8.69107 \mathrm{E}-02 & 0.00000 \mathrm{E}+00 & 0.00000 \mathrm{E}+00 & 0.00\end{array}$

$31131150.00000 E+00 \quad 0.00000 E+00 \quad 3.15103 E+00 \quad 5.97046 E-010.00000 E+00 \quad 0$

$\begin{array}{llllllllll}6 & 1311 & 5 & 0.00000 \mathrm{E}+00 & 0.00000 \mathrm{E}+00 & 3.39302 \mathrm{E}-01-1.81733 \mathrm{E}-01 & 0.00000 \mathrm{E}+00 & 0 .\end{array}$

$\begin{array}{lllllllllll}31411 & 5 & 0.00000 \mathrm{E}+00 & 0.00000 \mathrm{E}+00 & 0.00000 \mathrm{E}+00 & 3.31459 \mathrm{E}+00 & 4.33514 \mathrm{E}-01 & 0.0\end{array}$.

$\begin{array}{lllllllllll}6 & 1 & 1411 & 5 & 0.00000 E+00 & 0.00000 E+00 & 0.00000 E+00 & 2.85299 E-01-1.27730 E-01 & 0\end{array}$

$\begin{array}{llllllllll}3 & 1 & 1511 & 5 & 0.00000 \mathrm{E}+00 & 0.00000 \mathrm{E}+00 & 0.00000 \mathrm{E}+00 & 5.43846 \mathrm{E}-02 & 3.40059 \mathrm{E}+00 & 0\end{array}$

$\begin{array}{llllllllllll}6 & 1 & 1511 & 5 & 0.00000 \mathrm{E}+00 & 0.00000 \mathrm{E}+00 & 0.00000 \mathrm{E}+00 & 9.51863 \mathrm{E}-03 & 2.11565 \mathrm{E}-01 & 0 .\end{array}$

$\begin{array}{lllllllllll}3 & 1 & 1516 & 1 & 3.27247 E-01 & 0.00000 E+00 & 0.00000 E+00 & 0.00000 E+00 & 0.00000 E+00 & 0.00\end{array}$

$\begin{array}{lllllllllll}6 & 1 & 1516 & 1-6.18007 E-02 & 0.00000 E+00 & 0.00000 E+00 & 0.00000 E+00 & 0.00000 E+00 & 0\end{array}$

$\begin{array}{lllllllllllll}3 & 1 & 1611 & 5 & 0.00000 \mathrm{E}+00 & 0.00000 \mathrm{E}+00 & 0.00000 \mathrm{E}+00 & 3.08771 \mathrm{E}-14 & 2.46751 \mathrm{E}-01 & 0 .\end{array}$

$61161150.00000 \mathrm{E}+00 \quad 0.00000 \mathrm{E}+00 \quad 0.00000 \mathrm{E}+00-2.80049 \mathrm{E}-14-1.77337 \mathrm{E}-02 \quad 0$.

$\begin{array}{llllllllllll}3 & 1 & 1616 & 1 & 3.61522 \mathrm{E}+00 & 0.00000 E+00 & 0.00000 E+00 & 0.00000 E+00 & 0.00000 E+00 & 0 .\end{array}$

$\begin{array}{llllllllllllll}16 & 1 & 1616 & 1 & 1.83338 \mathrm{E}-01 & 0.00000 \mathrm{E}+00 & 0.00000 \mathrm{E}+00 & 0.00000 \mathrm{E}+00 & 0.00000 \mathrm{E}+00 & 0.0\end{array}$

$0 \begin{array}{lll}0 & 0 & 2\end{array}$ ALUMINUM-27 VERS 5 (FAST) + ALUMINUM VERS 4 MATE (THERMAL)

$121152.25083 \mathrm{E}-01 \quad 1.84379 \mathrm{E}-01 \quad 1.43689 \mathrm{E}-01 \quad 1.10590 \mathrm{E}-01 \quad 8.49440 \mathrm{E}-02 \quad 0$

$126 \begin{array}{llllllllll}5 & 6 & 1.41919 \mathrm{E}-01 & 2.35827 \mathrm{E}-01 & 2.53533 \mathrm{E}-01 & 2.53129 \mathrm{E}-01 & 2.52051 \mathrm{E}-01 & 0 .\end{array}$ 
Ilating 30 . continued.

$\begin{array}{llllllllllllll}12 & 11 & 1 & 5 & 2.52380 \mathrm{E}-01 & 2.50462 \mathrm{E}-01 & 2.48011 \mathrm{E}-01 & 2.44719 \mathrm{E}-01 & 2.38859 \mathrm{E}-01 & 0\end{array}$

$12161112.23006 \mathrm{E}-01 \quad 0.00000 \mathrm{E}+00 \quad 0.00000 \mathrm{E}+00 \quad 0.00000 \mathrm{E}+000.00000 \mathrm{E}+000$.

$\begin{array}{lllllllllllll}1 & 2 & 1 & 2 & 5 & 1.80449 \mathrm{E}-02 & 1.74297 \mathrm{E}-04 & 1.62598 \mathrm{E}-04 & 4.16257 \mathrm{E}-04 & 1.41786 \mathrm{E}-03 & 0 .\end{array}$

$1256 \begin{array}{lllllllllll}6 & 2 & 5 & 3.45517 \mathrm{E}-03 & 8.82689 \mathrm{E}-03 & 2.47629 \mathrm{E}-03 & 2.82994 \mathrm{E}-03 & 5.05645 \mathrm{E}-03 & 0\end{array}$

$\begin{array}{lllllllllllll}1 & 2 & 11 & 2 & 5 & 8.90149 \mathrm{E}-03 & 1.66599 \mathrm{E}-02 & 2.89931 \mathrm{E}-02 & 4.49353 \mathrm{E}-02 & 8.16649 \mathrm{E}-02 & 0 .\end{array}$

$12162211.83868 E-01$ r $00000 E+00 \quad 0.00000 E+00 \quad 0.00000 E+000.00000 E+00 \quad 0$.

$4211051.49392 E+00+.84542 E+00 \quad 2.30728 E+00 \quad 3.03547 E+00 \quad 4.17063 E+00 \quad 0$

$\begin{array}{llllllllllllll}42 & 6 & 0 & 5 & 3.48630 \mathrm{E}+00 & 1.45134 \mathrm{E}+00 & 1.31475 \mathrm{E}+00 & 1.31650 \mathrm{E}+00 & 1.31878 \mathrm{E}+00 & 0 .\end{array}$

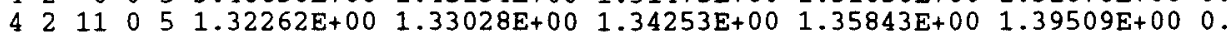

$\begin{array}{llllllllllll}42 & 16 & 0 & 1 & 1.49788 \mathrm{E}+00 & 0.00000 \mathrm{E}+00 & 0.00000 \mathrm{E}+00 & 0.00000 \mathrm{E}+00 & 0.00000 \mathrm{E}+000 . & 0.000\end{array}$

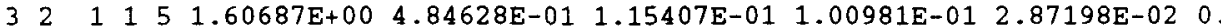

$6211158.47700 E-01 \quad 7.42507 E-03 \quad 9.41498 E-03-1.59475 E-03-4.83591 E-04 \quad 0$

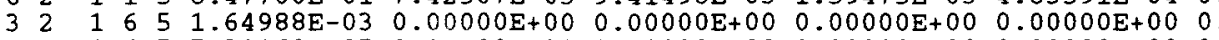

$\begin{array}{lllllllllllll}6 & 2 & 6 & 5-7.30169 E-05 & 0.0 & 000 E+00 & 0.00000 E+00 & 0.00000 E+00 & 0.00000 E+00 & 0.0\end{array}$

$3225150.00000 E+002 .-759 E+00 \quad 2.90984 E-01 \quad 1.05055 E-012.82620 E-02 \quad 0$

$622150.00000 E+001.1700 E+00-1.82424 E-02 \quad 1.44200 E-03-7.54219 E-04 \quad 0$

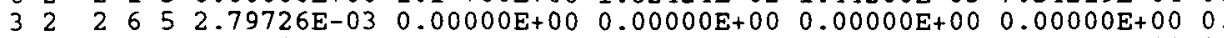

$6226 \quad 65-7.27289 E-06 \quad 0.00000 E+00 \quad 0.00000 E+00 \quad 0.00000 E+00 \quad 0.00000 E+00 \quad 0$.

$\begin{array}{lllllllllllll}3 & 2 & 3 & 1 & 5 & 0.00000 \mathrm{E}+00 & 0.00000 \mathrm{E}+00 & 2.85514 \mathrm{E}+00 & 4.96239 \mathrm{E}-01 & 6.01466 \mathrm{E}-02 & 0\end{array}$

$623 \quad 1 \quad 5 \quad 0.00000 \mathrm{E}+00 \quad 0.00000 \mathrm{E}+00 \quad 1.14728 \mathrm{E}+00-3.61674 \mathrm{E}-02 \quad 3.38988 \mathrm{E}-030$.

$3236565.50889 \mathrm{E}-03 \quad 0.00000 \mathrm{E}+00 \quad 0.00000 \mathrm{E}+00 \quad 0.00000 \mathrm{E}+000.00000 \mathrm{E}+00 \quad 0$.

$623365-5.85105 E-04 \quad 0.00000 E+00 \quad 0.00000 E+00 \quad 0.00000 E+00 \quad 0.00000 E+00 \quad 0$

$\begin{array}{llllllllllllll}3 & 2 & 4 & 1 & 5 & 0.00000 \mathrm{E}+00 & 0.00000 \mathrm{E}+00 & 0.00000 \mathrm{E}+00 & 3.72493 \mathrm{E}+00 & 2.11088 \mathrm{E}-01 & 0.0 .\end{array}$

$\begin{array}{lllllllllll}6 & 2 & 4 & 1 & 5 & 0.00000 \mathrm{E}+00 & 0.00000 \mathrm{E}+00 & 0.00000 \mathrm{E}+00 & 9.28508 \mathrm{E}-01-2.75444 \mathrm{E}-02 & 0\end{array}$

$325150.00000 E+00 \quad 0.00000 E+00 \quad 0.00000 E+00 \quad 0.00000 E+00 \quad 4.19662 E+00 \quad 0$.

$\begin{array}{llllllllllllll}6 & 2 & 5 & 1 & 5 & 0.00000 E+00 & 0.00000 E+00 & 0.00000 E+00 & 0.00000 E+00 & 3.73364 E-01 & 0 .\end{array}$

$32556552.45740 E-01 \quad 0.00000 E+00 \quad 0.00000 E+00 \quad 0.00000 E+00 \quad 0.00000 E+00 \quad 0$.

$62565-1.00213 \mathrm{E}-01 \quad 0.00000 \mathrm{E}+00 \quad 0.00000 \mathrm{E}+00 \quad 0.00000 \mathrm{E}+00 \quad 0.00000 \mathrm{E}+00 \quad 0$.

$32566 \begin{array}{lllllllllll}6 & 6 & 3.49812 \mathrm{E}+00 & 4.41375 \mathrm{E}-02 & 0.00000 \mathrm{E}+00 & 0.00000 \mathrm{E}+00 & 0.00000 \mathrm{E}+00 & 0\end{array}$

$\begin{array}{lllllllllllll}6 & 6 & 6 & 5 & 7.60891 \mathrm{E}-02-1.66757 \mathrm{E}-02 & 0.00000 \mathrm{E}+00 & 0.00000 \mathrm{E}+00 & 0.00000 \mathrm{E}+00 \quad 0 .\end{array}$

$\begin{array}{lllllllllllll}3 & 2 & 7 & 6 & 5 & 0.00000 \mathrm{E}+00 & 1.41310 \mathrm{E}+00 & 6.54396 \mathrm{E}-02 & 0.00000 \mathrm{E}+00 & 0.00000 \mathrm{E}+00 & 0.0 .\end{array}$

$62576 \begin{array}{lllllllll}6 & 7 & 6 & 0.00000 \mathrm{E}+00 & 5.70282 \mathrm{E}-02-2.10069 \mathrm{E}-02 & 0.00000 \mathrm{E}+00 & 0.00000 \mathrm{E}+00 & 0 .\end{array}$

$32886550.00000 \mathrm{E}+00 \quad 0.00000 \mathrm{E}+00 \quad 1.29014 \mathrm{E}+00 \quad 5.56819 \mathrm{E}-02 \quad 0.00000 \mathrm{E}+00 \quad 0$.

$6288650.00000 \mathrm{E}+00 \quad 0.00000 \mathrm{E}+00 \quad 5.11788 \mathrm{E}-02-1.76382 \mathrm{E}-02 \quad 0.00000 \mathrm{E}+000$.

$3259650.00000 \mathrm{E}+00 \quad 0.00000 \mathrm{E}+00 \quad 0.00000 \mathrm{E}+00 \quad 1.29182 \mathrm{E}+00 \quad 5.54189 \mathrm{E}-02 \quad 0$.

$6296550.00000 \mathrm{E}+00 \quad 0.00000 \mathrm{E}+00 \quad 0.00000 \mathrm{E}+00 \quad 5.11308 \mathrm{E}-02-1.75547 \mathrm{E}-02 \quad 0$.

$32106650.00000 E+00 \quad 0.00000 E+00 \quad 0.00000 E+00 \quad 0.00000 E+00 \quad 1.27731 E+00 \quad 0$.

$\begin{array}{lllllllllllll}6 & 2 & 10 & 6 & 5 & 0.00000 \mathrm{E}+00 & 0.00000 \mathrm{E}+00 & 0.00000 \mathrm{E}+00 & 0.00000 \mathrm{E}+00 & 5.54238 \mathrm{E}-02 & 0.00 .\end{array}$

$32101156.99903 \mathrm{E}-02 \quad 0.00000 \mathrm{E}+00 \quad 0.00000 \mathrm{E}+00 \quad 0.00000 \mathrm{E}+00 \quad 0.00000 \mathrm{E}+00 \quad 0$.

$6210115-2.18463 \mathrm{E}-02 \quad 0.00000 \mathrm{E}+00 \quad 0.00000 \mathrm{E}+00 \quad 0.000 \mathrm{C}+00 \quad 0.00000 \mathrm{E}+00 \quad 0$.

$32111151.25109 E+00 \quad 9.61998 E-02 \quad 0.00000 E+00 \quad 0.000+00 \quad 0.00000 E+000$.

$62111156.39604 \mathrm{E}-02-3.03830 \mathrm{E}-02 \quad 0.00000 \mathrm{E}+00 \quad 0.000 \quad+00 \quad 0.00000 \mathrm{E}+00 \quad 0$.

$32121150.00000 E+00 \quad 1.28543 E+00 \quad 6.17640 \mathrm{E}-02 \quad 0.00000 \mathrm{E}+00 \quad 0.00000 \mathrm{E}+00 \quad 0$

$\begin{array}{llllllllll}62 & 1211 & 5 & 0.00000 \mathrm{E}+00 & 5.31382 \mathrm{E}-02-1.95633 \mathrm{E}-02 & 0.00000 \mathrm{E}+00 & 0.00000 \mathrm{E}+000 . & 0.00\end{array}$

$32131150.00000 \mathrm{E}+00 \quad 0.00000 \mathrm{E}+00 \quad 1.21779 \mathrm{E}+00 \quad 1.29323 \mathrm{E}-010.00000 \mathrm{E}+00 \quad 0$.

$62131150.00000 E+00 \quad 0.00000 E+00 \quad 7.44779 E-02-4.09051 E-02 \quad 0.00000 E+00 \quad 0$

$\begin{array}{llllllllllll}3 & 2 & 1411 & 5 & 0.00000 \mathrm{E}+00 & 0.00000 \mathrm{E}+00 & 0.00000 \mathrm{E}+00 & 1.25181 \mathrm{E}+00 & 9.52593 \mathrm{E}-02 & 0.0 .\end{array}$

$\begin{array}{llllllllll}6 & 2 & 1411 & 5 & 0.00000 \mathrm{E}+00 & 0.00000 \mathrm{E}+00 & 0.00000 \mathrm{E}+00 & 6.29455 \mathrm{E}-02-2.93737 \mathrm{E}-02 & 0.0 .\end{array}$

$32151150.00000 E+00 \quad 0.00000 E+00 \quad 0.00000 E+00 \quad 0.00000 E+00 \quad 1.34700 E+00 \quad 0$.

$622151150.00000 E+00 \quad 0.00000 E+00 \quad 0.00000 E+00 \quad 0.00000 E+00 \quad 3.35703 E-02 \quad 0$.

32161611 1.34760E+00 $0.00000 \mathrm{E}+00 \quad 0.00000 \mathrm{E}+00 \quad 0.00000 \mathrm{E}+00 \quad 0.00000 \mathrm{E}+00 \quad 0$.

$\begin{array}{lllllllllllll}1 & 6 & 2 & 1616 & 1 & 3.35848 \mathrm{E}-02 & 0.00000 \mathrm{E}+00 & 0.00000 \mathrm{E}+00 & 0.00000 \mathrm{E}+00 & 0.00000 \mathrm{E}+00 & 0.00 .\end{array}$ $\begin{array}{llll}0 & 0 & 3 & \text { PLUTONIUM-239 VERS (FAST) + PLUTONIUM-239 VERS (THERMAL) }\end{array}$

$\begin{array}{llllllllllll}1 & 3 & 1 & 1 & 5 & 8.28686 \mathrm{E}-02 & 7.01084 \mathrm{E}-02 & 6.71238 \mathrm{E}-02 & 5.81989 \mathrm{E}-02 & 3.72416 \mathrm{E}-02 & 0 .\end{array}$

$\begin{array}{llllllllllll}1 & 3 & 6 & 1 & 5 & 2.58110 \mathrm{E}-02 & 2.14085 \mathrm{E}-02 & 1.50412 \mathrm{E}-02 & 7.33773 \mathrm{E}-03 & 3.67665 \mathrm{E}-03 & 0 .\end{array}$

$\begin{array}{llllllllllllll}1 & 3 & 11 & 1 & 5 & 2.08546 \mathrm{E}-03 & 5.92669 \mathrm{E}-03 & 8.96149 \mathrm{E}-03 & 1.77517 \mathrm{E}-03 & 1.70648 \mathrm{E}-04 & 0\end{array}$

$\begin{array}{lllllllllllll}1 & 3 & 16 & 1 & 1 & 3.86994 \mathrm{E}-04 & 0.00000 \mathrm{E}+00 & 0.00000 \mathrm{E}+00 & 0.00000 \mathrm{E}+00 & 0.00000 \mathrm{E}+00 & 0\end{array}$

$\begin{array}{llllllllllll}1 & 3 & 1 & 2 & 5 & 1.78883 \mathrm{E}+00 & 1.93799 \mathrm{E}+00 & 1.78966 \mathrm{E}+00 & 1.70751 \mathrm{E}+00 & 1.73155 \mathrm{E}+00 & 0.7 .\end{array}$

$\begin{array}{lllllllllllll}1 & 3 & 6 & 2 & 5 & 2.16192 \mathrm{E}+00 & 3.72921 \mathrm{E}+00 & 9.04315 \mathrm{E}+00 & 2.96344 \mathrm{E}+01 & 7.55658 \mathrm{E}+01 & 0 .\end{array}$

$13111251.48942 \mathrm{E}+02 \quad 4.59209 \mathrm{E}+01 \quad 2.73799 \mathrm{E}+01 \quad 1.77600 \mathrm{E}+02 \quad 2.00923 \mathrm{E}+03 \quad 0$.

$1316218.65119 \mathrm{E}+02 \quad 0.00000 \mathrm{E}+00 \quad 0.00000 \mathrm{E}+00 \quad 0.00000 \mathrm{E}+00 \quad 0.00000 \mathrm{E}+00 \quad 0$.

$\begin{array}{llllllllllll}1 & 3 & 1 & 3 & 5 & 6.23087 \mathrm{E}+00 & 6.08438 \mathrm{E}+00 & 5.33642 \mathrm{E}+00 & 4.80274 \mathrm{E}+00 & 4.46356 \mathrm{E}+00 & 0 .\end{array}$

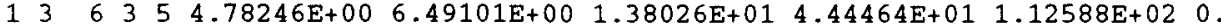

$\begin{array}{lllllllllllll}1 & 3 & 11 & 3 & 5 & 2.55753 E+02 & 8.12811 E+01 & 6.12685 E+01 & 3.46520 E+02 & 3.50592 E+03 & 0 .\end{array}$

$\begin{array}{lllllllllllll}1 & 3 & 16 & 3 & 1 & 1.79053 \mathrm{E}+03 & 0.00000 \mathrm{E}+00 & 0.00000 \mathrm{E}+00 & 0.00000 \mathrm{E}+00 & 0.00000 \mathrm{E}+000 . & 0.00\end{array}$

$\begin{array}{llllllllllll}1 & 3 & 1 & 4 & 5 & 1.79746 \mathrm{E}+00 & 1.92942 \mathrm{E}+00 & 1.76442 \mathrm{E}+00 & 1.62160 \mathrm{E}+00 & 1.53514 \mathrm{E}+00 & 0 .\end{array}$

$133 \quad 6 \quad 4 \quad 5 \quad 1.65845 \mathrm{E}+00 \quad 2.25349 \mathrm{E}+00 \quad 4.79279 \mathrm{E}+00 \quad 1.54340 \mathrm{E}+01 \quad 3.90963 \mathrm{E}+01 \quad 0$

$\begin{array}{lllllllllllll}1 & 3 & 11 & 4 & 5 & 8.88109 \mathrm{E}+01 & 2.82251 \mathrm{E}+01 & 2.12758 \mathrm{E}+01 & 1.20330 \mathrm{E}+02 & 1.21254 \mathrm{E}+03 \quad 0 .\end{array}$

$\begin{array}{llllllllllll}1 & 3 & 16 & 4 & 1 & 6.19264 \mathrm{E}+02 & 0.00000 \mathrm{E}+00 & 0.00000 \mathrm{E}+00 & 0.00000 \mathrm{E}+00 & 0.00000 \mathrm{E}+00 & 0.00\end{array}$

$431105154.06115 \mathrm{E}+00 \quad 4.68554 \mathrm{E}+00 \quad 4.98528 \mathrm{E}+00 \quad 5.80944 \mathrm{E}+00 \quad 8.97957 \mathrm{E}+00 \quad 0$

$\begin{array}{llllllllllllll}43 & 6 & 0 & 5 & 1.28207 \mathrm{E}+01 & 1.55813 \mathrm{E}+01 & 2.21771 \mathrm{E}+01 & 4.54128 \mathrm{E}+01 & 9.04735 \mathrm{E}+01 & 0 .\end{array}$

$43110051.59970 \mathrm{E}+02 \quad 5.44882 \mathrm{E}+01 \quad 3.72036 \mathrm{E}+01 \quad 1.88976 \mathrm{E}+02 \quad 2.01905 \mathrm{E}+030$.

$4316 \quad 0 \quad 1 \quad 8.72907 \mathrm{E}+02 \quad 0.00000 \mathrm{E}+00 \quad 0.00000 \mathrm{E}+00 \quad 0.00000 \mathrm{E}+00 \quad 0.00000 \mathrm{E}+00 \quad 0$.

$\begin{array}{llllllllllllll}3 & 3 & 1 & 1 & 5 & 4.82413 \mathrm{E}+00 & 2.66927 \mathrm{E}-01 & 2.92358 \mathrm{E}-01 & 3.73782 \mathrm{E}-01 & 2.13079 \mathrm{E}-01 & 0 .\end{array}$

$\begin{array}{lllllllllllll}6 & 3 & 1 & 1 & 5 & 3.70356 \mathrm{E}+00 & 5.96342 \mathrm{E}-03 & 0.00000 \mathrm{E}+00 & 0.00000 \mathrm{E}+00 & 0.00000 \mathrm{E}+00 \quad 0\end{array}$

$\begin{array}{llllllllllll}3 & 3 & 1 & 6 & 5 & 1.15699 \mathrm{E}-02 & 1.12137 \mathrm{E}-07 & 0.00000 \mathrm{E}+00 & 0.00000 \mathrm{E}+00 & 0.00000 \mathrm{E}+00 & 0.0\end{array}$

$\begin{array}{llllllllllllll}6 & 3 & 1 & 6 & 5 & 0.00000 \mathrm{E}+00 & 0.00000 \mathrm{E}+00 & 0.00000 \mathrm{E}+00 & 0.00000 \mathrm{E}+00 & 0.00000 \mathrm{E}+00 & 0.0\end{array}$

$\begin{array}{llllllllllllll}3 & 3 & 2 & 1 & 5 & 0.00000 \mathrm{E}+00 & 4.31429 \mathrm{E}+00 & 3.97226 \mathrm{E}-01 & 4.00968 \mathrm{E}-01 & 2.56089 \mathrm{E}-01 & 0 .\end{array}$

$632150.00000 \mathrm{E}+00 \quad 2.63585 \mathrm{E}+00 \quad 2.21696 \mathrm{E}-03-1.35733 \mathrm{E}-04 \quad 0.00000 \mathrm{E}+00 \quad 0$.

$3326551.69048 \mathrm{E}-02 \quad 0.00000 \mathrm{E}+00 \quad 0.00000 \mathrm{E}+00 \quad 0.00000 \mathrm{E}+00 \quad 0.00000 \mathrm{E}+00 \quad 0$. 


\section{Listing 30. continued.}

$\begin{array}{lllllllllll}6326 & 0.00000 \mathrm{E}+00 & 0.00000 \mathrm{E}+00 & 0.00000 \mathrm{E}+00 & 0.00000 \mathrm{E}+00 & 0.00000 \mathrm{E}+00 & 0.0\end{array}$

$33331550.00000 E+00 \quad 0.00000 E+00 \quad 4.37488 E+00 \quad 6.93487 E-012.42860 E-010$.

$63331550.00000 \mathrm{E}+00 \quad 0.00000 \mathrm{E}+00 \quad 2.11549 \mathrm{E}+00 \quad 7.61330 \mathrm{E}-03-9.35741 \mathrm{E}-040$.

$\begin{array}{llllllllllll}3 & 3 & 3 & 5 & 6.56306 \mathrm{E}-03 & 0.00000 \mathrm{E}+00 & 0.00000 \mathrm{E}+00 & 0.00000 \mathrm{E}+00 & 0.00000 \mathrm{E}+00 & 0 .\end{array}$

$\begin{array}{llllllllllll}6 & 3 & 3 & 6 & 5 & 0.00000 \mathrm{E}+00 & 0.00000 \mathrm{E}+00 & 0.00000 \mathrm{E}+00 & 0.00000 \mathrm{E}+00 & 0.00000 \mathrm{E}+00 & 0.0\end{array}$

$\begin{array}{llllllllllll}3 & 3 & 4 & 1 & 5 & 0.00000 \mathrm{E}+00 & 0.00000 \mathrm{E}+00 & 0.00000 \mathrm{E}+00 & 5.95005 \mathrm{E}+00 & 4.25297 \mathrm{E}-01 & 0 .\end{array}$

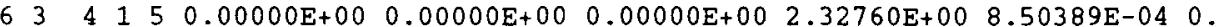

$3344655.48634 \mathrm{E}-02 \quad 0.00000 \mathrm{E}+00 \quad 0.00000 \mathrm{E}+00 \quad 0.00000 \mathrm{E}+00 \quad 0.00000 \mathrm{E}+00 \quad 0$.

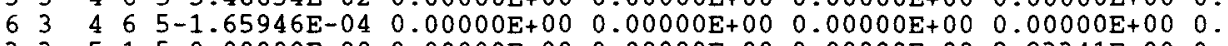

$\begin{array}{lllllllllll}3 & 3 & 1 & 5 & 0.00000 \mathrm{E}+00 & 0.00000 \mathrm{E}+00 & 0.00000 \mathrm{E}+00 & 0.00000 \mathrm{E}+00 & 8.83341 \mathrm{E}+00 & 0 .\end{array}$

$\begin{array}{llllllllllll}6 & 3 & 5 & 1 & 5 & 0.00000 \mathrm{E}+00 & 0.00000 \mathrm{E}+00 & 0.00000 \mathrm{E}+00 & 0.00000 \mathrm{E}+00 & 1.78655 \mathrm{E}+00 & 0 .\end{array}$

$\begin{array}{llllllllllll}3 & 3 & 5 & 6 & 5 & 1.84357 \mathrm{E}-01 & 0.00000 \mathrm{E}+00 & 0.00000 \mathrm{E}+00 & 0.00000 \mathrm{E}+00 & 0.00000 \mathrm{E}+00 & 0 .\end{array}$

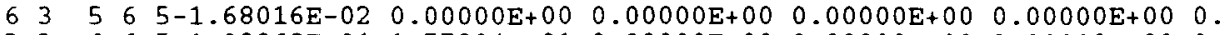

$\begin{array}{llllllllllll}3 & 3 & 6 & 6 & 5 & 1.08868 \mathrm{E}+01 & 1.57804 \mathrm{E}-01 & 0.00000 \mathrm{E}+00 & 0.00000 \mathrm{E}+00 & 0.00000 \mathrm{E}+00 & 0 .\end{array}$

$\begin{array}{llllllllllll}6 & 3 & 6 & 6 & 5 & 4.09032 \mathrm{E}-01-2.32190 \mathrm{E}-02 & 0.00000 \mathrm{E}+00 & 0.00000 \mathrm{E}+00 & 0.00000 \mathrm{E}+00 & 0 .\end{array}$

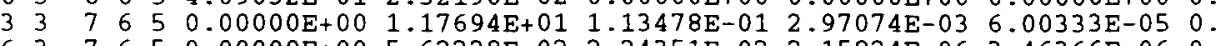

$63776550.00000 \mathrm{E}+00 \quad 5.62228 \mathrm{E}-02-2.24351 \mathrm{E}-02-2.15824 \mathrm{E}-06-3.46366 \mathrm{E}-060$.

$\begin{array}{lllllllllll}3 & 3 & 8 & 6 & 5 & 0.00000 \mathrm{E}+00 & 0.00000 \mathrm{E}+00 & 1.30699 \mathrm{E}+01 & 1.01108 \mathrm{E}-01 & 0.00000 \mathrm{E}+00 & 0 .\end{array}$

$\begin{array}{lllllllllll}6 & 3 & 8 & 6 & 5 & 0.00000 E+00 & 0.00000 E+00 & 7.05821 E-02 & -3.35326 E-02 & 0.00000 E+00 & 0 .\end{array}$

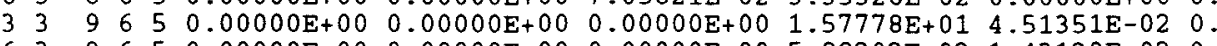

$\begin{array}{llllllllll}6 & 3 & 9 & 6 & 5 & 0.00000 \mathrm{E}+00 & 0.00000 \mathrm{E}+00 & 0.00000 \mathrm{E}+00 & 5.88202 \mathrm{E}-02-1.43129 \mathrm{E}-02 & 0 .\end{array}$

$\begin{array}{llllllllll}3 & 3 & 10 & 6 & 5 & 0.00000 \mathrm{E}+00 & 0.00000 \mathrm{E}+00 & 0.00000 \mathrm{E}+00 & 0.00000 \mathrm{E}+00 & 1.48977 \mathrm{E}+010 .\end{array}$

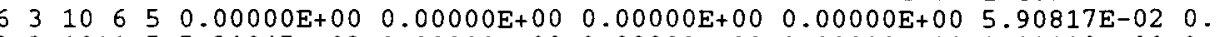

$\begin{array}{lllllllll}3 & 3 & 10115 & 5.21045 \mathrm{E}-02 & 0.00000 \mathrm{E}+00 & 0.00000 \mathrm{E}+00 & 0.00000 \mathrm{E}+00 & 0.00000 \mathrm{E}+00 & 0 .\end{array}$

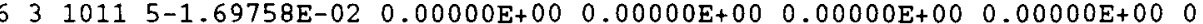

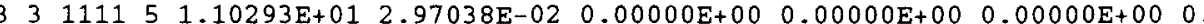

$\begin{array}{lllllllll}6 & 3 & 1111 & 5 & 4.08724 \mathrm{E}-02-9.78399 \mathrm{E}-03 & 0.00000 \mathrm{E}+00 & 0.00000 \mathrm{E}+00 & 0.00000 \mathrm{E}+00 & 0 .\end{array}$

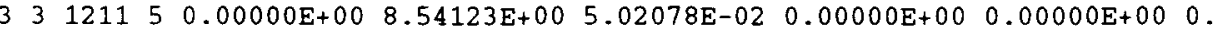

$\begin{array}{llllllllll}6 & 3 & 1211 & 5 & 0.00000 \mathrm{E}+00 & 4.08388 \mathrm{E}-02-1.66436 \mathrm{E}-02 & 0.00000 \mathrm{E}+00 & 0.00000 \mathrm{E}+00 & 0\end{array}$

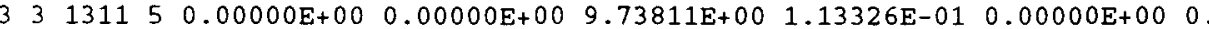

$\begin{array}{lllllllll}6 & 3 & 13115 & 0.00000 \mathrm{E}+00 & 0.00000 \mathrm{E}+00 & 6.52245 \mathrm{E}-02-3.75134 \mathrm{E}-02 & 0.00000 \mathrm{E}+00 & 0 .\end{array}$

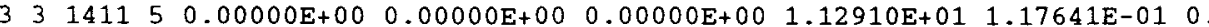

$\begin{array}{lllllllll}6 & 3 & 14115 & 0.00000 \mathrm{E}+00 & 0.00000 \mathrm{E}+00 & 0.00000 \mathrm{E}+00 & 7.03811 \mathrm{E}-02-3.83102 \mathrm{E}-02 & 0\end{array}$

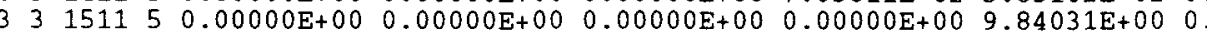

$\begin{array}{llllllllll}6 & 3 & 15115 & 0.00000 \mathrm{E}+00 & 0.00000 \mathrm{E}+00 & 0.00000 \mathrm{E}+00 & 0.00000 \mathrm{E}+00 & 2.74454 \mathrm{E}-02 & 0 .\end{array}$

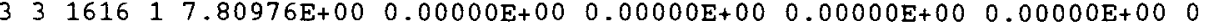

$\begin{array}{llllllllll}163 & 3616 & 1 & 2.19546 \mathrm{E}-02 & 0.00000 \mathrm{E}+00 & 0.00000 \mathrm{E}+00 & 0.00000 \mathrm{E}+00 & 0.00000 \mathrm{E}+00 & 0\end{array}$ 
L1sting 31. Table 1 Case 7, scAup tnput using Bansen-Roach cross sections.

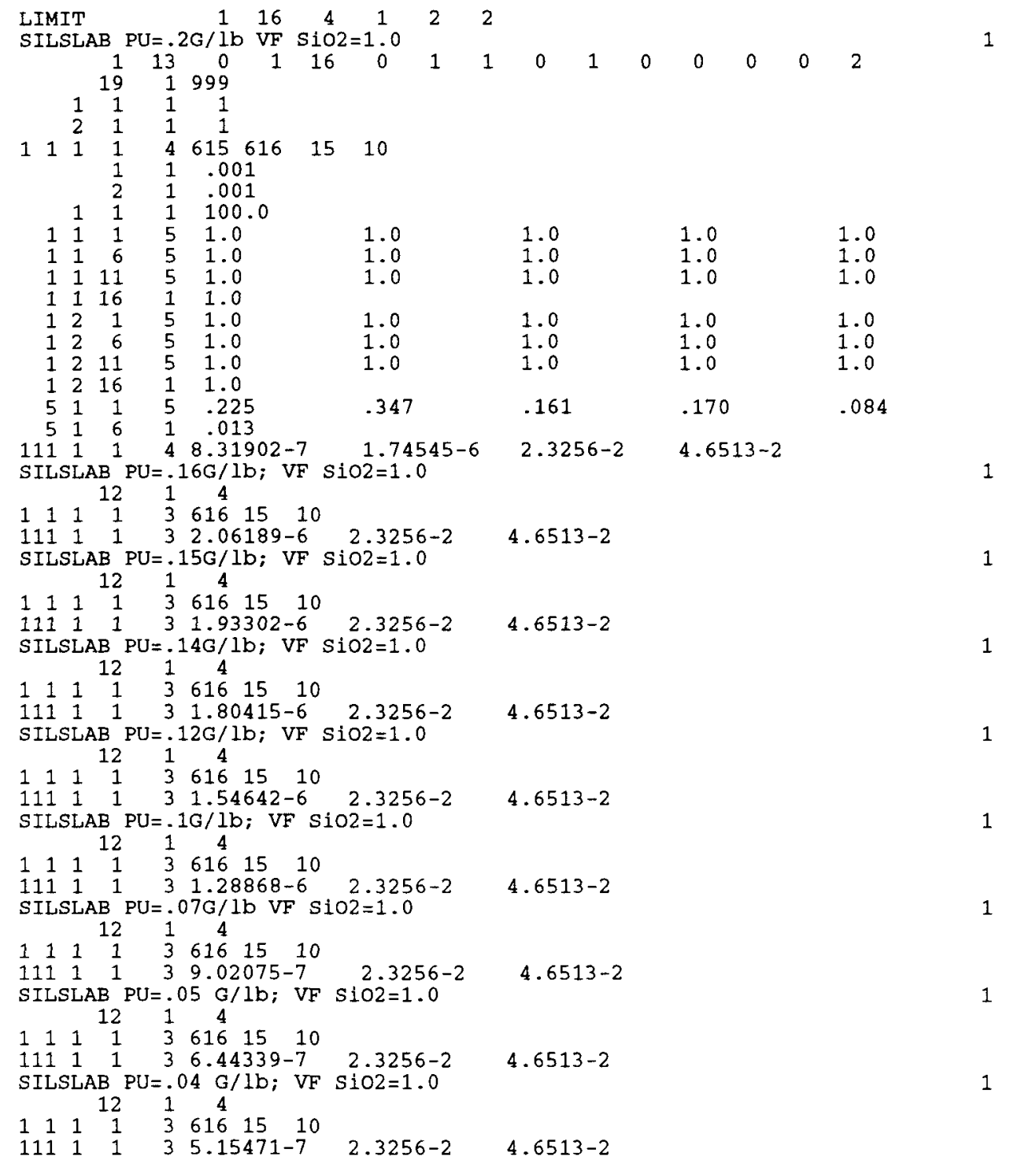


Iisting 32. Table 1 Case 7, KBNO-V.a input using Hanson-Roach cross sections.

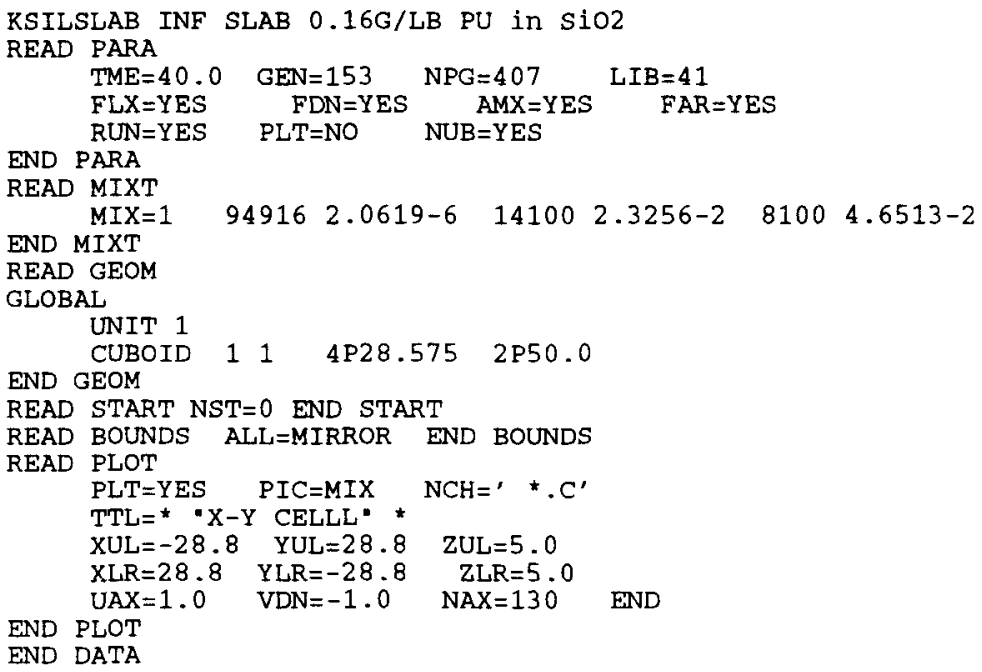

Listing 33. Table 1 Case 7, KRNo-v, a Input using csAs and 27-group cross sections.

$=\operatorname{CSAS} 25$

CSILSLAB $0.16 \mathrm{~g}$ Pu $/ 1 \mathrm{~b}$ SiO2

27GROUPNDF4 INFHOMMEDIUM

PU-239 $1002.0619-6$ END

SI $11002.3256-2$ END

$0 \quad 11004.6513-2$ END

KSILSLAB INF SLAB $0.16 \mathrm{G} / \mathrm{LB}$ PU in SiO2

READ PARA

TME $=60.0 \quad$ GEN $=153 \quad N P G=407$

FLX $=Y E S \quad F D N=Y E S \quad A M X=Y E S \quad F A R=Y E S$

END PARA

RUN $=$ YES PLT $=$ NO NUB $=$ YES

READ GEOM

GLOBAL

$\begin{array}{lllll}\text { UNIT } 1 & & & \\ \text { CUBOID } & 1 & 1 & 4 P 28.575 & 2 P 50.0\end{array}$

END GEOM

READ START NST $=0$ END START

READ BOUNDS ALL=MIRROR END BOUNDS

READ PLO'T

PLT $=$ YES $\quad \mathrm{PIC}=\mathrm{MIX} \quad \mathrm{NCH}=\prime \quad * . \mathrm{C}^{\prime}$

TTL $=$ * 'X $\mathrm{X}$ Y CELLL" *

$X U L=-28.8 \quad$ YUL $=28.8 \quad Z U L=5.0$

$\mathrm{XLR}=28.8 \quad \mathrm{YLR}=-28.8 \quad \mathrm{ZLR}=5.0$

END PLOT

$\mathrm{UAX}=1.0 \quad \mathrm{VDN}=-1.0 \quad \mathrm{NAX}=130 \quad \mathrm{END}$

END DATA

Listing 34. Table 1 Case 7, MCNP input.

MSILSLAB INF SLAB $.16 \mathrm{G} / L B$ PU IN SILICON DIOXIDE

$1 \quad \begin{array}{lllllllll} & 6.97710619 e-2 & -1 & 2 & -3 & 4 & -5 & 6 & \text { imp: } n=1\end{array}$ Slab

*1 px 28.575 \$asterisk means reflecting surface

$\star 2 \quad \mathrm{px}-28.575$

$* 3$ py 28.575

$* 4$ py -28.575

* $5 \quad \mathrm{pz} 50.0$

kcode $100012014550000 \quad \$ n p g=1000, n s k=20$ gen=145

sdef cel=1 \$starting source in cell 1

print

$\mathrm{m} 1 \quad 94239.50 \mathrm{c} \quad 2.0619 \mathrm{e}-6 \quad 14000.50 \mathrm{c} \quad 2.3256 \mathrm{e}-2 \quad 8016.50 \mathrm{c} \quad 4.6513 \mathrm{e}-2$ 
Ileting 35. Table 1 case 7, covorks input.

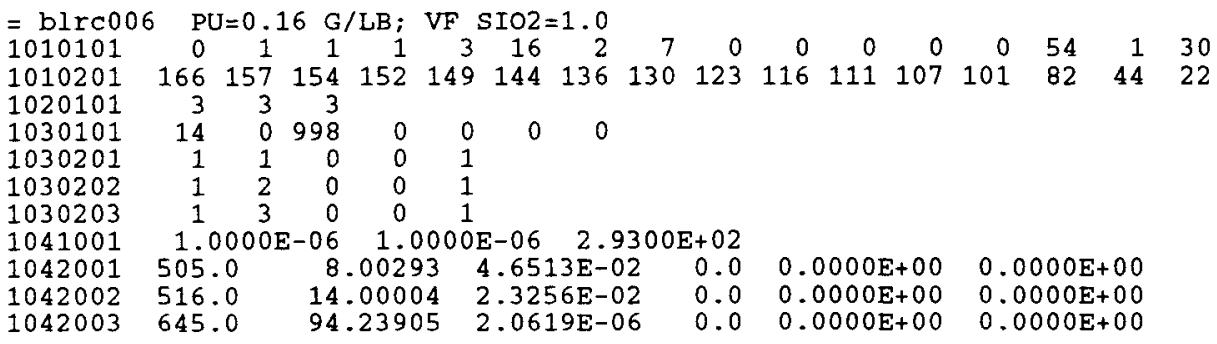

-

Listing 36. Table 1 Case 7, sckMp 1pput with combrks generated crose sections.

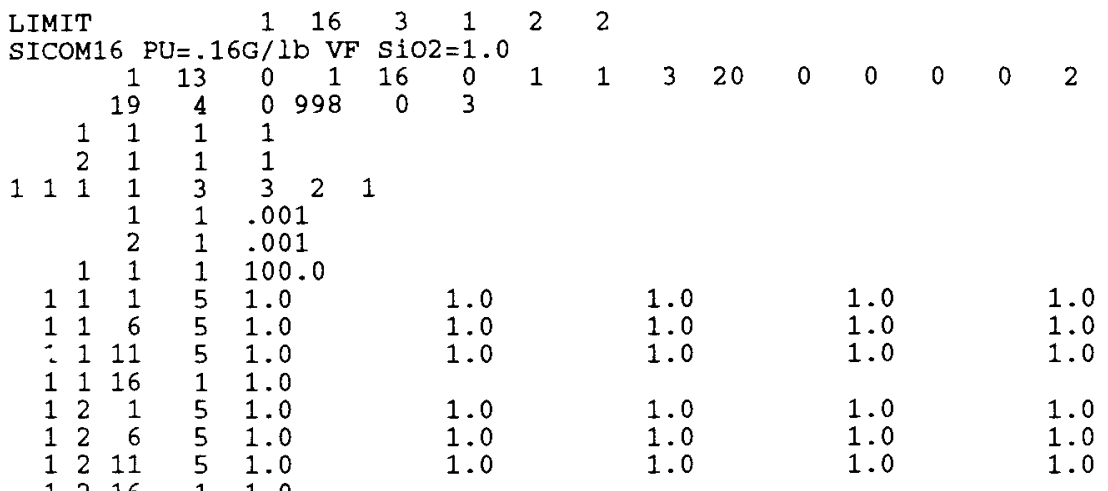

$5255974 E-01348185 E-01 \quad 1.71622 E-01139795 E-017.01995 E-02$

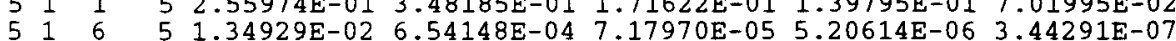

$511144.84487 E-08 \quad 1.24487 E-08 \quad 9.90516 E-10 \quad 3.69914 E-10$

$\begin{array}{llllll}111 & 1 & 1 & 3 & 2.061900-06 & 2.325600-02 \quad 4.651300-02\end{array}$

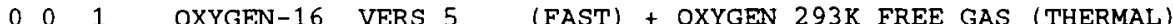

$\begin{array}{llllllllllll}1 & 1 & 1 & 1 & 5 & 2.60897 \mathrm{E}-01 & 2.72274 \mathrm{E}-01 & 9.14483 \mathrm{E}-02 & 1.14400 \mathrm{E}-01 & 8.77847 \mathrm{E}-02 & 0\end{array}$

$\begin{array}{llllllllllll}1 & 1 & 6 & 1 & 5 & 9.24801 \mathrm{E}-02 & 9.31671 \mathrm{E}-02 & 9.28930 \mathrm{E}-02 & 9.28351 \mathrm{E}-02 & 9.26699 \mathrm{E}-02 & 0 .\end{array}$

$\begin{array}{llllllllllll}1 & 1 & 11 & 1 & 5 & 9.29584 \mathrm{E}-02 & 9.27863 \mathrm{E}-02 & 9.27501 \mathrm{E}-02 & 9.25623 \mathrm{E}-02 & 9.10577 \mathrm{E}-02 & 0 .\end{array}$

$\begin{array}{llllllllllllll}1 & 1 & 16 & 1 & 1 & 8.90998 \mathrm{E}-02 & 0.00000 \mathrm{E}+00 & 0.00000 \mathrm{E}+00 & 0.00000 \mathrm{E}+00 & 0.00000 \mathrm{E}+00 & 0\end{array}$

$\begin{array}{llllllllllll}1 & 1 & 1 & 2 & 5 & 3.27739 \mathrm{E}-02 & 2.20760 \mathrm{E}-08 & 2.76403 \mathrm{E}-08 & 3.68787 \mathrm{E}-08 & 6.52450 \mathrm{E}-08 & 0 .\end{array}$

$\begin{array}{lllllllllllll}1 & 1 & 6 & 2 & 5 & 1.46794 \mathrm{E}-07 & 3.43514 \mathrm{E}-07 & 7.81001 \mathrm{E}-07 & 1.87326 \mathrm{E}-06 & 3.88581 \mathrm{E}-06 & 0\end{array}$

$\begin{array}{lllllllllllll}1 & 1 & 11 & 2 & 5 & 6.83591 \mathrm{E}-06 & 1.27525 \mathrm{E}-05 & 2.22439 \mathrm{E}-05 & 3.45389 \mathrm{E}-05 & 6.70957 \mathrm{E}-05 & 0\end{array}$

$\begin{array}{lllllllllllll}1 & 1 & 16 & 2 & 1 & 1.53332 \mathrm{E}-04 & 0.00000 \mathrm{E}+00 & 0.00000 \mathrm{E}+00 & 0.00000 \mathrm{E}+00 & 0.00000 \mathrm{E}+000 & 0.000\end{array}$

$\begin{array}{lllllllllll}4 & 1 & 1 & 0 & 5 & 1.48601 \mathrm{E}+00 & 1.43680 \mathrm{E}+00 & 3.73289 \mathrm{E}+00 & 3.42573 \mathrm{E}+00 & 3.93702 \mathrm{E}+00 & 0 .\end{array}$

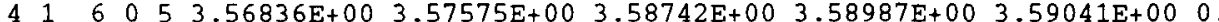

$\begin{array}{lllllllllll}4 & 1 & 11 & 0 & 5 & 3.59052 E+00 & 3.59052 E+00 & 3.59053 E+00 & 3.59057 E+00 & 3.62471 E+00 & 0 .\end{array}$

$\begin{array}{llllllllllll}4 & 1 & 16 & 0 & 1 & 3.71242 \mathrm{E}+00 & 0.00000 \mathrm{E}+00 & 0.00000 \mathrm{E}+00 & 0.00000 \mathrm{E}+00 & 0.00000 \mathrm{E}+000 . & 0.000\end{array}$

$\begin{array}{lllllllllllll}3 & 1 & 1 & 1 & 5 & 1.59044 \mathrm{E}+00 & 3.98766 \mathrm{E}-01 & 2.47518 \mathrm{E}-03 & 2.17020 \mathrm{E}-03 & 7.36352 \mathrm{E}-04 & 0\end{array}$

$6111156.94314 \mathrm{E}-01-1.53430 \mathrm{E}-01 \quad 6.47608 \mathrm{E}-04-2.43361 \mathrm{E}-05-1.20197 \mathrm{E}-04 \quad 0$.

$\begin{array}{llllllllllll}3 & 1 & 1 & 6 & 5 & 2.24819 \mathrm{E}-05 & 0.00000 \mathrm{E}+00 & 0.00000 \mathrm{E}+00 & 0.00000 \mathrm{E}+00 & 0.00000 \mathrm{E}+00 & 0.00\end{array}$

$\begin{array}{llllllllll}6 & 1 & 6 & 5-9.40849 \mathrm{E}-06 & 0.00000 \mathrm{E}+00 & 0.00000 \mathrm{E}+00 & 0.00000 \mathrm{E}+00 & 0.00000 \mathrm{E}+000 . & 0.000\end{array}$

$3112150.00000 E+001.19069 E+00 \quad 3.59744 E-01 \quad 0.00000 E+00 \quad 0.00000 E+00 \quad 0$

$\begin{array}{lllllllllll}6 & 1 & 2 & 1 & 5 & 0.00000 \mathrm{E}+00 & 1.89972 \mathrm{E}-01-7.63356 \mathrm{E}-02 & 0.00000 \mathrm{E}+00 & 0.00000 \mathrm{E}+00 & 0\end{array}$

$\begin{array}{lllllllllll}3 & 1 & 3 & 1 & 5 & 0.00000 \mathrm{E}+00 & 0.00000 \mathrm{E}+00 & 2.83616 \mathrm{E}+00 & 1.01233 \mathrm{E}+00 & 0.00000 \mathrm{E}+00 & 0.00\end{array}$

$\begin{array}{lllllllllllll}6 & 1 & 3 & 1 & 5 & 0.00000 \mathrm{E}+00 & 0.00000 \mathrm{E}+00 & 4.31518 \mathrm{E}-01-3.15919 \mathrm{E}-01 & 0.00000 \mathrm{E}+00 & 0\end{array}$

$\begin{array}{llllllllllll}3 & 1 & 4 & 1 & 5 & 0.00000 \mathrm{E}+00 & 0.00000 \mathrm{E}+00 & 0.00000 \mathrm{E}+00 & 3.46908 \mathrm{E}+00 & 6.45881 \mathrm{E}-01 & 0\end{array}$

$614150.00000 \mathrm{E}+00 \quad 0.00000 \mathrm{E}+00 \quad 0.00000 \mathrm{E}+00 \quad 8.32034 \mathrm{E}-01-1.42800 \mathrm{E}-010$.

$\begin{array}{lllllllllll}3 & 1 & 5 & 1 & 5 & 0.00000 \mathrm{E}+00 & 0.00000 \mathrm{E}+00 & 0.00000 \mathrm{E}+00 & 0.00000 \mathrm{E}+00 & 3.11487 \mathrm{E}+00 \quad 0 .\end{array}$

$\begin{array}{lllllllllll}6 & 1 & 5 & 1 & 5 & 0.00000 \mathrm{E}+00 & 0.00000 \mathrm{E}+00 & 0.00000 \mathrm{E}+00 & 0.00000 \mathrm{E}+00-1.03860 \mathrm{E}-01 & 0\end{array}$

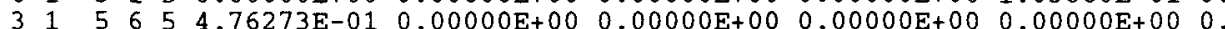

$\begin{array}{llllllllll}6 & 1 & 5 & 6 & 5-2.42010 \mathrm{E}-01 & 0.00000 \mathrm{E}+00 & 0.00000 \mathrm{E}+00 & 0.00000 \mathrm{E}+00 & 0.00000 \mathrm{E}+00 & 0.00\end{array}$

$\begin{array}{llllllllllllll}3 & 1 & 6 & 6 & 5 & 3.43320 \mathrm{E}+00 & 2.27925 \mathrm{E}-01 & 0.00000 \mathrm{E}+00 & 0.00000 \mathrm{E}+00 & 0.00000 \mathrm{E}+00 & 0 .\end{array}$

$\begin{array}{lllllllllllll}61 & 6 & 6 & 5 & 1.62060 \mathrm{E}-01-6.93013 \mathrm{E}-02 & 0.00000 \mathrm{E}+00 & 0.00000 \mathrm{E}+00 & 0.00000 \mathrm{E}+00 & 0 .\end{array}$

$\begin{array}{llllllllllll}3 & 1 & 6 & 5 & 0.00000 \mathrm{E}+00 & 3.43300 \mathrm{E}+00 & 2.99669 \mathrm{E}-01 & 0.00000 \mathrm{E}+00 & 0.00000 \mathrm{E}+00 & 0.00\end{array}$

$\begin{array}{llllllllllll}6 & 1 & 6 & 5 & 0.00000 \mathrm{E}+00 & 2.48248 \mathrm{E}-01-9.13284 \mathrm{E}-02 & 0.00000 \mathrm{E}+00 & 0.00000 \mathrm{E}+00 & 0.00\end{array}$

$31186550.00000 E+00 \quad 0.00000 E+00 \quad 3.48707 E+00 \quad 2.57782 E-01 \quad 0.00000 E+00 \quad 0$

$\begin{array}{llllllllllll}6 & 8 & 6 & 5 & 0.00000 \mathrm{E}+00 & 0.00000 \mathrm{E}+00 & 2.36015 \mathrm{E}-01-7.85824 \mathrm{E}-02 & 0.00000 \mathrm{E}+00 & 0\end{array}$

$\begin{array}{llllllllllll}3 & 1 & 9 & 6 & 5 & 0.00000 \mathrm{E}+00 & 0.00000 \mathrm{E}+00 & 0.00000 \mathrm{E}+00 & 3.48992 \mathrm{E}+00 & 2.57480 \mathrm{E}-01 & 0.01\end{array}$

$\begin{array}{llllllllllll}6 & 1 & 9 & 6 & 5 & 0.00000 \mathrm{E}+00 & 0.00000 \mathrm{E}+00 & 0.00000 \mathrm{E}+00 & 2.36112 \mathrm{E}-01-7.85717 \mathrm{E}-02 & 0\end{array}$

$\begin{array}{lllllllllllllll}3 & 1 & 10 & 6 & 5 & 0.00000 \mathrm{E}+00 & 0.00000 \mathrm{E}+00 & 0.00000 \mathrm{E}+00 & 0.00000 \mathrm{E}+00 & 3.37888 \mathrm{E}+00 & 0 .\end{array}$

$\begin{array}{llllllllllllll}6 & 1 & 10 & 6 & 5 & 0.00000 \mathrm{E}+00 & 0.00000 \mathrm{E}+00 & 0.00000 \mathrm{E}+00 & 0.00000 \mathrm{E}+00 & 2.63251 \mathrm{E}-01 & 0.00\end{array}$

$\begin{array}{lllllllllll}3 & 1 & 1011 & 5 & 3.69091 \mathrm{E}-01 & 0.00000 \mathrm{E}+00 & 0.00000 \mathrm{E}+00 & 0.00000 \mathrm{E}+00 & 0.00000 \mathrm{E}+00 & 0.00\end{array}$

$\begin{array}{lllllllllll}6 & 1 & 1011 & 5-1.05687 \mathrm{E}-01 & 0.00000 \mathrm{E}+00 & 0.00000 \mathrm{E}+00 & 0.00000 \mathrm{E}+00 & 0.00000 \mathrm{E}+00 & 0\end{array}$

$\begin{array}{llllllllllll}3 & 1 & 1111 & 5 & 3.28998 \mathrm{E}+00 & 4.58096 \mathrm{E}-01 & 0.00000 \mathrm{E}+00 & 0.00000 \mathrm{E}+00 & 0.00000 \mathrm{E}+00 & 0\end{array}$

$\begin{array}{lllllllllll}6 & 1 & 1111 & 5 & 2.97044 \mathrm{E}-01-1.39475 \mathrm{E}-01 & 0.00000 \mathrm{E}+00 & 0.00000 \mathrm{E}+00 & 0.00000 \mathrm{E}+00 & 0.00\end{array}$ 
Lieting 36. continued.

$\begin{array}{lllllllllll}3 & 1 & 12115 & 0.00000 \mathrm{E}+00 & 3.45978 \mathrm{E}+00 & 2.88298 \mathrm{E}-01 & 0.00000 \mathrm{E}+00 & 0.00000 \mathrm{E}+00 & 0 .\end{array}$

$\begin{array}{lllllllll}6 & 1 & 1211 & 5 & 0.00000 \mathrm{E}+00 & 2.45498 \mathrm{E}-01-8.79296 \mathrm{E}-02 & 0.00000 \mathrm{E}+00 & 0.00000 \mathrm{E}+00 & 0 .\end{array}$

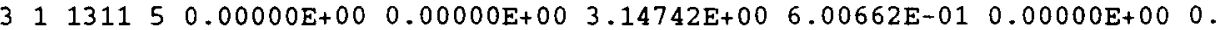

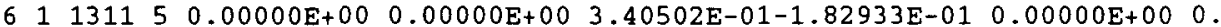

$\begin{array}{llllllllll}3 & 1 & 1411 & 5 & 0.00000 \mathrm{E}+00 & 0.00000 \mathrm{E}+00 & 0.00000 \mathrm{E}+00 & 3.30317 \mathrm{E}+00 & 4.44932 \mathrm{E}-010 .\end{array}$

$\begin{array}{llllllll}6 & 1 & 1411 & 5 & 0.00000 \mathrm{E}+00 & 0.00000 \mathrm{E}+00 & 0.00000 \mathrm{E}+00 & 2.89608 \mathrm{E}-01-1.32039 \mathrm{E}-010 .\end{array}$

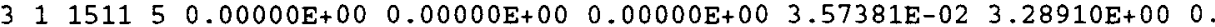

$\begin{array}{lllllllll}61 & 15115 & 0.00000 \mathrm{E}+00 & 0.00000 \mathrm{E}+00 & 0.00000 \mathrm{E}+00 & 5.81033 \mathrm{E}-03 & 2.29541 \mathrm{E}-01 & 0 .\end{array}$

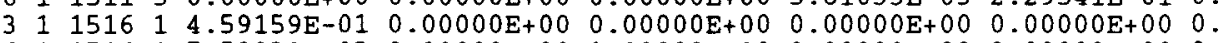

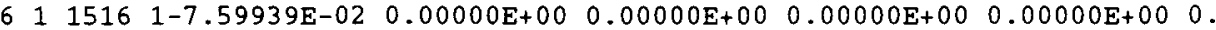

$\begin{array}{llllllllll}3 & 1 & 1611 & 5 & 0.00000 \mathrm{E}+00 & 0.00000 \mathrm{E}+00 & 0.00000 \mathrm{E}+00 & 2.19050 \mathrm{E}-14 & 1.93090 \mathrm{E}-01 & 0 .\end{array}$.

$\begin{array}{llllllll}61 & 1611 & 5 & 0.00000 \mathrm{E}+00 & 0.00000 \mathrm{E}+00 & 0.00000 \mathrm{E}+00-1.98218 \mathrm{E}-14-1.67221 \mathrm{E}-02 & 0 .\end{array}$

$\begin{array}{llllllllll}3 & 1 & 1616 & 1 & 3.68573 \mathrm{E}+00 & 0.00000 \mathrm{E}+00 & 0.00000 \mathrm{E}+00 & 0.00000 \mathrm{E}+00 & 0.00000 \mathrm{E}+00 & 0 .\end{array}$

$\begin{array}{llllllllllll}1 & 6 & 1 & 1616 & 1 & 1.83277 \mathrm{E}-01 & 0.00000 \mathrm{E}+00 & 0.00000 \mathrm{E}+00 & 0.00000 \mathrm{E}+00 & 0.00000 \mathrm{E}+00 & 0 .\end{array}$ $\begin{array}{llllll}0 & 0 & 2 & \text { SILICON VERS } 5 \text { (FAST) + SILICON VERS (THERMAL) }\end{array}$

$1211552.32300 \mathrm{E}-01 \quad 1.80622 \mathrm{E}-01 \quad 1.52291 \mathrm{E}-01 \quad 1.15015 \mathrm{E}-01$ 1.07570E-01 0 .

$126 \begin{array}{lllllllll}1 & 2 & 5 & 1.85717 \mathrm{E}-01 & 1.67335 \mathrm{E}-01 & 1.64283 \mathrm{E}-01 & 1.63017 \mathrm{E}-01 & 1.63006 \mathrm{E}-01 & 0 .\end{array}$

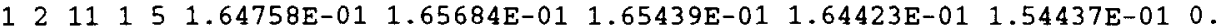

$\begin{array}{llllllllllll}12 & 16 & 1 & 1 & 1.49294 \mathrm{E}-01 & 0.00000 \mathrm{E}+00 & 0.00000 \mathrm{E}+00 & 0.00000 \mathrm{E}+00 & 0.00000 \mathrm{E}+00 & 0 .\end{array}$

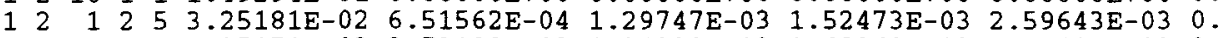

$\begin{array}{llllllllllll}12 & 6 & 2 & 5 & 3.35070 \mathrm{E}-03 & 2.73198 \mathrm{E}-03 & 1.24228 \mathrm{E}-03 & 1.68969 \mathrm{E}-03 & 3.50586 \mathrm{E}-03 & 0 .\end{array}$

$12112556.18118 \mathrm{E}-03 \quad 1.15244 \mathrm{E}-02 \quad 2.00683 \mathrm{E}-02 \quad 3.12131 \mathrm{E}-02 \quad 5.97300 \mathrm{E}-02 \quad 0$.

$\begin{array}{llllllllll}12 & 16 & 2 & 1 & 1.36424 \mathrm{E}-01 & 0.00000 \mathrm{E}+00 & 0.00000 \mathrm{E}+00 & 0.00000 \mathrm{E}+00 & 0.00000 \mathrm{E}+00 & 0 .\end{array}$

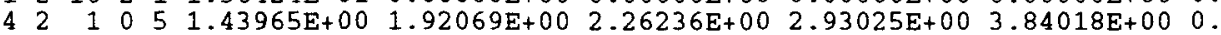

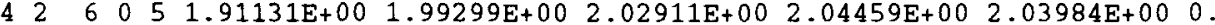

$\begin{array}{llllllllll}42 & 11 & 0 & 5 & 2.02700 \mathrm{E}+00 & 2.01138 \mathrm{E}+00 & 2.01375 \mathrm{E}+00 & 2.02480 \mathrm{E}+00 & 2.15825 \mathrm{E}+00 & 0 .\end{array}$

$4216012.23495 \mathrm{E}+00 \quad 0.00000 \mathrm{E}+00 \quad 0.00000 \mathrm{E}+00 \quad 0.00000 \mathrm{E}+00 \quad 0.00000 \mathrm{E}+00 \quad 0$.

$\begin{array}{lllllllllll}3 & 2 & 1 & 1 & 5 & 1.55749 \mathrm{E}+00 & 4.64253 \mathrm{E}-01 & 1.51698 \mathrm{E}-01 & 1.73816 \mathrm{E}-02 & 4.66450 \mathrm{E}-03 & 0 .\end{array}$

$62111507.88229 \mathrm{E}-01 \quad 6.69916 \mathrm{E}-03-6.21536 \mathrm{E}-03-1.07272 \mathrm{E}-04-1.73266 \mathrm{E}-040$.

$\begin{array}{lllllllllll}3 & 2 & 1 & 6 & 5 & 7.00775 \mathrm{E}-05 & 0.00000 \mathrm{E}+00 & 0.00000 \mathrm{E}+00 & 0.00000 \mathrm{E}+00 & 0.00000 \mathrm{E}+00 & 0 .\end{array}$

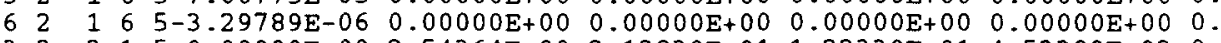

$\begin{array}{lllllllllll}3 & 2 & 2 & 1 & 5 & 0.00000 \mathrm{E}+00 & 2.54364 \mathrm{E}+00 & 2.12830 \mathrm{E}-01 & 1.22330 \mathrm{E}-01 & 4.53389 \mathrm{E}-02 & 0 .\end{array}$

$62 \quad 2 \quad 1 \quad 5 \quad 0.00000 \mathrm{E}+00 \quad 1.03006 \mathrm{E}+00-1.90688 \mathrm{E}-02 \quad 1.35044 \mathrm{E}-02-5.22259 \mathrm{E}-030$.

$\begin{array}{lllllllllll}3 & 2 & 2 & 6 & 5 & 1.40676 \mathrm{E}-02 & 2.48691 \mathrm{E}-03 & 9.17683 \mathrm{E}-05 & 0.00000 \mathrm{E}+00 & 0.00000 \mathrm{E}+00 & 0 .\end{array}$

$62526551.41167 \mathrm{E}-03 \quad 8.43784 \mathrm{E}-05-2.11901 \mathrm{E}-05 \quad 0.00000 \mathrm{E}+00 \quad 0.00000 \mathrm{E}+000$.

$\begin{array}{lllllllllll}3 & 2 & 3 & 1 & 5 & 0.00000 \mathrm{E}+00 & 0.00000 \mathrm{E}+00 & 2.91919 \mathrm{E}+00 & 4.95674 \mathrm{E}-01 & 0.00000 \mathrm{E}+00 & 0 .\end{array}$

$\begin{array}{lllllllllll}6 & 2 & 3 & 1 & 5 & 0.00000 \mathrm{E}+00 & 0.00000 \mathrm{E}+00 & 1.13777 \mathrm{E}+00 & 1.60615 \mathrm{E}-02 & 0.00000 \mathrm{E}+00 & 0 .\end{array}$

$32536564.14963 \mathrm{E}-05 \quad 1.09069 \mathrm{E}-05 \quad 4.44006 \mathrm{E}-07 \quad 0.00000 \mathrm{E}+00 \quad 0.00000 \mathrm{E}+000$.

$62336551.45552 \mathrm{E}-05-1.91452 \mathrm{E}-06-1.53116 \mathrm{E}-07 \quad 0.00000 \mathrm{E}+00 \quad 0.00000 \mathrm{E}+000$.

$3251550.00000 \mathrm{E}+00 \quad 0.00000 \mathrm{E}+00 \quad 0.00000 \mathrm{E}+00 \quad 3.33299 \mathrm{E}+00 \quad 1.92614 \mathrm{E}-010$.

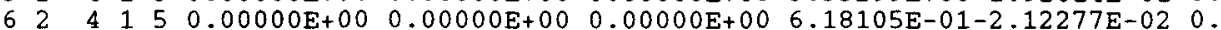

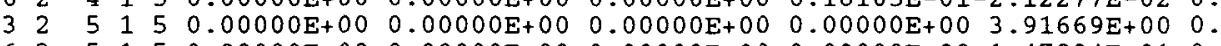

$\begin{array}{lllllllllll}6 & 2 & 1 & 5 & 0.00000 \mathrm{E}+00 & 0.00000 \mathrm{E}+00 & 0.00000 \mathrm{E}+00 & 0.00000 \mathrm{E}+00 & 1.47894 \mathrm{E}-01 & 0 .\end{array}$

$\begin{array}{llllllllllll}32 & 5 & 6 & 5 & 5.31465 \mathrm{E}-02 & 0.00000 \mathrm{E}+00 & 0.00000 \mathrm{E}+00 & 0.00000 \mathrm{E}+00 & 0.00000 \mathrm{E}+00 & 0 .\end{array}$

$\begin{array}{llllllllll}62 & 5 & 6 & 5-1.56362 \mathrm{E}-02 & 0.00000 \mathrm{E}+00 & 0.00000 \mathrm{E}+00 & 0.00000 \mathrm{E}+00 & 0.00000 \mathrm{E}+00 & 0 .\end{array}$

$325666551.92266 \mathrm{E}+00 \quad 6.91458 \mathrm{E}-02 \quad 0.00000 \mathrm{E}+00 \quad 0.00000 \mathrm{E}+00 \quad 0.00000 \mathrm{E}+000$.

$\begin{array}{llllllllll}6 & 2 & 6 & 6 & 5 & 1.05790 \mathrm{E}-01-2.19455 \mathrm{E}-02 & 0.00000 \mathrm{E}+00 & 0.00000 \mathrm{E}+00 & 0.00000 \mathrm{E}+00 & 0 .\end{array}$

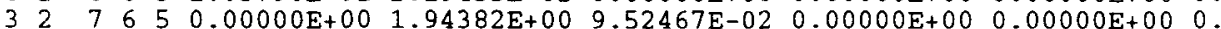

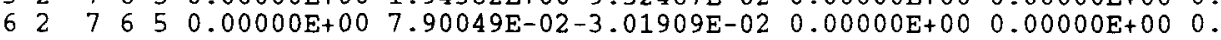

$3288650.00000 \mathrm{E}+00 \quad 0.00000 \mathrm{E}+00 \quad 1.99442 \mathrm{E}+00 \quad 8.31848 \mathrm{E}-02 \quad 0.00000 \mathrm{E}+00 \quad 0$.

$\begin{array}{llllllllll}62 & 8 & 6 & 5 & 0.00000 \mathrm{E}+00 & 0.00000 \mathrm{E}+00 & 7.61237 \mathrm{E}-02-2.63799 \mathrm{E}-02 & 0.00000 \mathrm{E}+00 & 0 .\end{array}$

$\begin{array}{llllllllll}32 & 9 & 6 & 5 & 0.00000 \mathrm{E}+00 & 0.00000 \mathrm{E}+00 & 0.00000 \mathrm{E}+00 & 2.00974 \mathrm{E}+00 & 8.32712 \mathrm{E}-02 & 0 .\end{array}$

$6296550.00000 \mathrm{E}+00 \quad 0.00000 \mathrm{E}+00 \quad 0.00000 \mathrm{E}+00 \quad 7.65490 \mathrm{E}-02-2.64362 \mathrm{E}-020$.

$\begin{array}{lllllllllll}3 & 2 & 10 & 6 & 5 & 0.00000 \mathrm{E}+00 & 0.00000 \mathrm{E}+00 & 0.00000 \mathrm{E}+00 & 0.00000 \mathrm{E}+00 & 1.98166 \mathrm{E}+00 & 0 .\end{array}$

$\begin{array}{llllllllllll}6 & 2 & 10 & 6 & 5 & 0.00000 \mathrm{E}+00 & 0.00000 \mathrm{E}+00 & 0.00000 \mathrm{E}+00 & 0.00000 \mathrm{E}+00 & 8.26698 \mathrm{E}-02 & 0 .\end{array}$

$\begin{array}{llllllllll}3 & 2 & 1011 & 5 & 1.04622 \mathrm{E}-01 & 0.00000 \mathrm{E}+00 & 0.00000 \mathrm{E}+00 & 0.00000 \mathrm{E}+00 & 0.00000 \mathrm{E}+00 & 0.00\end{array}$

$6210115-3.27177 \mathrm{E}-02 \quad 0.00000 \mathrm{E}+00 \quad 0.00000 \mathrm{E}+00 \quad 0.00000 \mathrm{E}+00 \quad 0.00000 \mathrm{E}+000$.

$\begin{array}{llllllllll}3 & 2 & 1111 & 5 & 1.92695 \mathrm{E}+00 & 1.43433 \mathrm{E}-01 & 0.00000 \mathrm{E}+00 & 0.00000 \mathrm{E}+00 & 0.00000 \mathrm{E}+00 & 0 .\end{array}$

$\begin{array}{lllllllll}6 & 2 & 11115 & 5 & 9.51181 \mathrm{E}-02-4.55472 \mathrm{E}-02 & 0.00000 \mathrm{E}+00 & 0.00000 \mathrm{E}+00 & 0.00000 \mathrm{E}+00 & 0 .\end{array}$

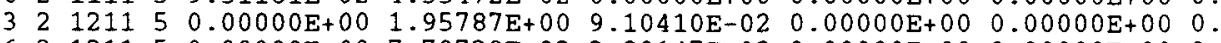

$\begin{array}{lllllllll}6 & 2 & 1211 & 5 & 0.00000 \mathrm{E}+00 & 7.79729 \mathrm{E}-02-2.89147 \mathrm{E}-02 & 0.00000 \mathrm{E}+00 & 0.00000 \mathrm{E}+00 & 0 .\end{array}$

$\begin{array}{lllllllllll}3 & 2 & 1311 & 5 & 0.00000 \mathrm{E}+00 & 0.00000 \mathrm{E}+00 & 1.85285 \mathrm{E}+00 & 1.89743 \mathrm{E}-01 & 0.00000 \mathrm{E}+00 & 0 .\end{array}$

$\begin{array}{llllllll}62 & 1311 & 5 & 0.00000 \mathrm{E}+00 & 0.00000 \mathrm{E}+00 & 1.09079 \mathrm{E}-01-6.01733 \mathrm{E}-02 & 0.00000 \mathrm{E}+00 & 0 .\end{array}$

$32141150.00000 \mathrm{E}+00 \quad 0.00000 \mathrm{E}+00 \quad 0.00000 \mathrm{E}+00 \quad 1.89984 \mathrm{E}+00 \quad 1.42650 \mathrm{E}-010$.

$\begin{array}{llllllll}62 & 14115 & 0.00000 \mathrm{E}+00 & 0.00000 \mathrm{E}+00 & 0.00000 \mathrm{E}+00 & 9.33243 \mathrm{E}-02-4.44212 \mathrm{E}-02 & 0 .\end{array}$

$\begin{array}{llllllll}32 & 15115 & 0.00000 \mathrm{E}+00 & 0.00000 \mathrm{E}+00 & 0.00000 \mathrm{E}+00 & 0.00000 \mathrm{E}+00 & 2.15000 \mathrm{E}+00 & 0 .\end{array}$

$\begin{array}{lllllllll}62 & 1511 & 5 & 0.00000 \mathrm{E}+00 & 0.00000 \mathrm{E}+00 & 0.00000 \mathrm{E}+00 & 0.00000 \mathrm{E}+00 & 5.14770 \mathrm{E}-02 & 0 .\end{array}$

$\begin{array}{llllllllll}32 & 1616 & 1 & 2.15000 \mathrm{E}+00 & 0.00000 \mathrm{E}+00 & 0.00000 \mathrm{E}+00 & 0.00000 \mathrm{E}+00 & 0.00000 \mathrm{E}+00 & 0 .\end{array}$

$\begin{array}{lllllllllll}16 & 2 & 1616 & 1 & 5.14770 \mathrm{E}-02 & 0.00000 \mathrm{E}+00 & 0.00000 \mathrm{E}+00 & 0.00000 \mathrm{E}+00 & 0.00000 \mathrm{E}+00 & 0 .\end{array}$ $0 \begin{array}{lll}0 & 0 & 3 \\ \text { PLUTONIUM-239 VERS (FAST) + PLUTONIUM-239 VERS (THERMAL) }\end{array}$

$\begin{array}{llllllllllll}1 & 3 & 1 & 1 & 5 & 8.24866 \mathrm{E}-02 & 7.02444 \mathrm{E}-02 & 6.72189 \mathrm{E}-02 & 5.85071 \mathrm{E}-02 & 3.55568 \mathrm{E}-02 & 0 .\end{array}$.

$\begin{array}{lllllllllll}13 & 6 & 1 & 5 & 2.63987 \mathrm{E}-02 & 2.13778 \mathrm{E}-02 & 1.50405 \mathrm{E}-02 & 7.33308 \mathrm{E}-03 & 3.68033 \mathrm{E}-03 & 0\end{array}$

$\begin{array}{llllllllllll}1 & 3 & 11 & 1 & 5 & 2.07334 \mathrm{E}-03 & 5.95276 \mathrm{E}-03 & 8.95205 \mathrm{E}-03 & 1.74660 \mathrm{E}-03 & 1.85698 \mathrm{E}-04 & 0 .\end{array}$

$\begin{array}{llllllllllll}1 & 3 & 16 & 1 & 1 & 3.67441 \mathrm{E}-04 & 0.00000 \mathrm{E}+00 & 0.00000 \mathrm{E}+00 & 0.00000 \mathrm{E}+00 & 0.00000 \mathrm{E}+00 & 0 .\end{array}$

$\begin{array}{llllllllll}1 & 3 & 1 & 2 & 5 & 1.78959 \mathrm{E}+00 & 1.93710 \mathrm{E}+00 & 1.79098 \mathrm{E}+00 & 1.70810 \mathrm{E}+00 & 1.73604 \mathrm{E}+000 .\end{array}$

$\begin{array}{llllllllll}1 & 3 & 6 & 2 & 5 & 2.11989 \mathrm{E}+00 & 3.73907 \mathrm{E}+00 & 9.04557 \mathrm{E}+00 & 2.96602 \mathrm{E}+01 & 7.54746 \mathrm{E}+010 .\end{array}$

$\begin{array}{lllllllllll}1 & 3 & 11 & 2 & 5 & 1.49678 \mathrm{E}+02 & 4.56657 \mathrm{E}+01 & 2.74155 \mathrm{E}+01 & 1.80037 \mathrm{E}+02 & 1.80814 \mathrm{E}+03 & 0 .\end{array}$

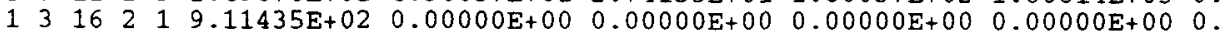

$\begin{array}{llllllllllll}1 & 3 & 1 & 3 & 5 & 6.21502 \mathrm{E}+00 & 6.08568 \mathrm{E}+00 & 5.34206 \mathrm{E}+00 & 4.80873 \mathrm{E}+00 & 4.46415 \mathrm{E}+00 & 0 .\end{array}$

$1366354.73922 \mathrm{E}+00 \quad 6.49426 \mathrm{E}+00 \quad 1.38058 \mathrm{E}+01 \quad 4.44756 \mathrm{E}+01 \quad 1.12307 \mathrm{E}+02 \quad 0$. 
LIsting 36. continued.

$13113552.57174 E+02 \quad 8.08960 E+01 \quad 6.13337 E+013.51082 E+02 \quad 3.16934 E+03 \quad 0$.

$13163311.89897 \mathrm{E}+03 \quad 0.00000 \mathrm{E}+00 \quad 0.00000 \mathrm{E}+00 \quad 0.00000 \mathrm{E}+00 \quad 0.00000 \mathrm{E}+0000$.

$\begin{array}{llllllllllll}1 & 3 & 1 & 4 & 5 & 1.79734 \mathrm{E}+00 & 1.92864 \mathrm{E}+00 & 1.76594 \mathrm{E}+00 & 1.62325 \mathrm{E}+00 & 1.53628 \mathrm{E}+00 & 0 .\end{array}$

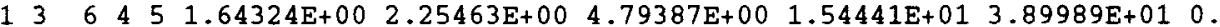

$\begin{array}{llllllllllll}1 & 3 & 11 & 4 & 5 & 8.93044 \mathrm{E}+01 & 2.80914 \mathrm{E}+01 & 2.12984 \mathrm{E}+01 & 1.21914 \mathrm{E}+02 & 1.09613 \mathrm{E}+03 & 0 .\end{array}$

$\begin{array}{llllllllllll}1 & 3 & 16 & 4 & 1 & 6.56766 \mathrm{E}+02 & 0.00000 \mathrm{E}+00 & 0.00000 \mathrm{E}+00 & 0.00000 \mathrm{E}+00 & 0.00000 \mathrm{E}+00 & 0 .\end{array}$

$43 \quad 1 \quad 0 \quad 5 \quad 4.07339 \mathrm{E}+00 \quad 4.66452 \mathrm{E}+00 \quad 4.98584 \mathrm{E}+00 \quad 5.79385 \mathrm{E}+00 \quad 9.24494 \mathrm{E}+000$.

$43 \quad 6 \quad 0 \quad 5 \quad 1.26261 \mathrm{E}+01 \quad 1.55990 \mathrm{E}+01 \quad 2.21796 \mathrm{E}+01 \quad 4.54396 \mathrm{E}+01 \quad 9.03666 \mathrm{E}+01 \quad 0$.

$43110551.60710 \mathrm{E}+02 \quad 5.42386 \mathrm{E}+01 \quad 3.72401 \mathrm{E}+01 \quad 1.91430 \mathrm{E}+02 \quad 1.81718 \mathrm{E}+030$.

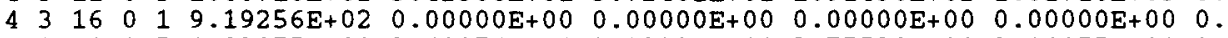

$\begin{array}{lllllllllll}3 & 3 & 1 & 1 & 5 & 4.83075 \mathrm{E}+00 & 2.68976 \mathrm{E}-01 & 2.93334 \mathrm{E}-01 & 3.75528 \mathrm{E}-01 & 2.14155 \mathrm{E}-01 & 0 .\end{array}$

$\begin{array}{llllllllllll}6 & 3 & 1 & 1 & 5 & 3.70419 \mathrm{E}+00 & 6.33809 \mathrm{E}-03 & 0.00000 \mathrm{E}+00 & 0.00000 \mathrm{E}+00 & 0.00000 \mathrm{E}+00 & 0 .\end{array}$

$\begin{array}{lllllllllll}3 & 3 & 1 & 6 & 5 & 1.15799 \mathrm{E}-02 & 1.07359 \mathrm{E}-07 & 0.00000 \mathrm{E}+00 & 0.00000 \mathrm{E}+00 & 0.00000 \mathrm{E}+00 & 0 .\end{array}$

$\begin{array}{llllllllllll}6 & 3 & 1 & 6 & 5 & 0.00000 \mathrm{E}+00 & 0.00000 \mathrm{E}+00 & 0.00000 \mathrm{E}+00 & 0.00000 \mathrm{E}+00 & 0.00000 \mathrm{E}+00 & 0 .\end{array}$

$33251550.00000 E+00 \quad 4.32677 E+00 \quad 3.94329 E-01 \quad 4.01732 E-012.56189 E-010$.

$\begin{array}{lllllllll}6 & 3 & 1 & 5 & 0.00000 \mathrm{E}+00 & 2.66660 \mathrm{E}+00 & 1.93841 \mathrm{E}-03-1.19803 \mathrm{E}-04 & 0.00000 \mathrm{E}+00 & 0 .\end{array}$

$\begin{array}{lllllllllll}3 & 3 & 2 & 6 & 5 & 1.68103 \mathrm{E}-02 & 0.00000 \mathrm{E}+00 & 0.00000 \mathrm{E}+00 & 0.00000 \mathrm{E}+00 & 0.00000 \mathrm{E}+00 & 0 .\end{array}$

$\begin{array}{lllllllllllll}6 & 3 & 2 & 6 & 5 & 0.00000 \mathrm{E}+00 & 0.00000 \mathrm{E}+00 & 0.00000 \mathrm{E}+00 & 0.00000 \mathrm{E}+00 & 0.00000 \mathrm{E}+00 & 0 .\end{array}$

$\begin{array}{llllllllllll}3 & 3 & 3 & 1 & 5 & 0.00000 \mathrm{E}+00 & 0.00000 \mathrm{E}+00 & 4.37486 \mathrm{E}+00 & 6.89612 \mathrm{E}-01 & 2.41767 \mathrm{E}-01 & 0 .\end{array}$

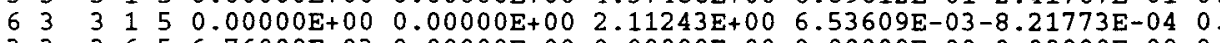

$\begin{array}{llllllllllll}3 & 3 & 3 & 6 & 5 & 6.76000 E-03 & 0.00000 E+00 & 0.00000 E+00 & 0.00000 E+00 & 0.00000 E+00 & 0 .\end{array}$

$\begin{array}{llllllllllll}6 & 3 & 3 & 5 & 0.00000 E+00 & 0.00000 E+00 & 0.00000 E+00 & 0.00000 E+00 & 0.00000 E+00 & 0 .\end{array}$

$\begin{array}{llllllllllll}3 & 3 & 1 & 5 & 0.00000 \mathrm{E}+00 & 0.00000 \mathrm{E}+00 & 0.00000 \mathrm{E}+00 & 5.93056 \mathrm{E}+00 & 4.26181 \mathrm{E}-01 & 0 .\end{array}$

$\begin{array}{llllllllllll}6 & 3 & 4 & 1 & 5 & 0.00000 \mathrm{E}+00 & 0.00000 \mathrm{E}+00 & 0.00000 \mathrm{E}+00 & 2.32327 \mathrm{E}+00 & 8.70615 \mathrm{E}-04 & 0 .\end{array}$

$\begin{array}{lllllllllll}3 & 3 & 4 & 6 & 5 & 5.29820 \mathrm{E}-02 & 0.00000 \mathrm{E}+00 & 0.00000 \mathrm{E}+00 & 0.00000 \mathrm{E}+00 & 0.00000 \mathrm{E}+00 & 0 .\end{array}$

$\begin{array}{llllllllll}6 & 3 & 6 & 5-1.65786 \mathrm{E}-04 & 0.00000 \mathrm{E}+00 & 0.00000 \mathrm{E}+00 & 0.00000 \mathrm{E}+00 & 0.00000 \mathrm{E}+00 & 0 .\end{array}$

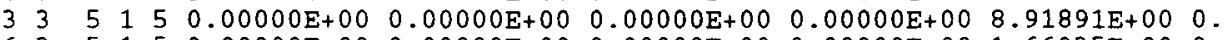

$\begin{array}{llllllllll}6 & 3 & 1 & 5 & 0.00000 E+00 & 0.00000 E+00 & 0.00000 E+00 & 0.00000 E+00 & 1.66035 E+00 & 0 .\end{array}$

$\begin{array}{llllllllllll}3 & 3 & 5 & 6 & 5 & 2.26331 E-01 & 0.00000 E+00 & 0.00000 E+00 & 0.00000 E+00 & 0.00000 E+00 & 0 .\end{array}$

$\begin{array}{llllllllll}63 & 5 & 6 & 5-2.40159 \mathrm{E}-02 & 0.00000 \mathrm{E}+00 & 0.00000 \mathrm{E}+00 & 0.00000 \mathrm{E}+00 & 0.00000 \mathrm{E}+00 & 0 .\end{array}$

$\begin{array}{lllllllllll}3 & 3 & 6 & 6 & 5 & 1.08844 \mathrm{E}+01 & 1.28893 \mathrm{E}-01 & 0.00000 \mathrm{E}+00 & 0.00000 \mathrm{E}+00 & 0.00000 \mathrm{E}+00 & 0.0\end{array}$

$\begin{array}{lllllllllll}6 & 3 & 6 & 6 & 5 & 5.22741 \mathrm{E}-01-1.55745 \mathrm{E}-02 & 0.00000 \mathrm{E}+00 & 0.00000 \mathrm{E}+00 & 0.00000 \mathrm{E}+00 & 0 .\end{array}$

$\begin{array}{llllllllllll}3 & 3 & 7 & 6 & 5 & 0.00000 \mathrm{E}+00 & 1.17802 \mathrm{E}+01 & 1.10633 \mathrm{E}-01 & 2.88327 \mathrm{E}-03 & 5.82658 \mathrm{E}-05 & 0 .\end{array}$

$\begin{array}{llllllll}6 & 3 & 7 & 6 & 5 & 0.00000 \mathrm{E}+00 & 5.54718 \mathrm{E}-02-2.16732 \mathrm{E}-02-2.05291 \mathrm{E}-06-3.29462 \mathrm{E}-06 & 0 .\end{array}$

$\begin{array}{llllllllllll}3 & 3 & 8 & 6 & 5 & 0.00000 \mathrm{E}+00 & 0.00000 \mathrm{E}+00 & 1.30698 \mathrm{E}+01 & 1.01291 \mathrm{E}-01 & 0.00000 \mathrm{E}+00 & 0 .\end{array}$

$\begin{array}{lllllllllll}6 & 3 & 8 & 6 & 5 & 0.00000 \mathrm{E}+00 & 0.00000 \mathrm{E}+00 & 7.06154 \mathrm{E}-02-3.35657 \mathrm{E}-02 & 0.00000 \mathrm{E}+00 & 0 .\end{array}$

$\begin{array}{lllllllllll}3 & 3 & 9 & 6 & 5 & 0.00000 \mathrm{E}+00 & 0.00000 \mathrm{E}+00 & 0.00000 \mathrm{E}+00 & 1.57786 \mathrm{E}+01 & 4.53690 \mathrm{E}-02 & 0 .\end{array}$

$\begin{array}{llllllllll}6 & 3 & 9 & 6 & 5 & 0.00000 \mathrm{E}+00 & 0.00000 \mathrm{E}+00 & 0.00000 \mathrm{E}+00 & 5.89013 \mathrm{E}-02-1.43900 \mathrm{E}-02 & 0 .\end{array}$

$33106650.00000 \mathrm{E}+00 \quad 0.00000 \mathrm{E}+00 \quad 0.00000 \mathrm{E}+00 \quad 0.00000 \mathrm{E}+00 \quad 1.48815 \mathrm{E}+010$

$\begin{array}{lllllllllll}6 & 3 & 10 & 6 & 5 & 0.00000 \mathrm{E}+00 & 0.00000 \mathrm{E}+00 & 0.00000 \mathrm{E}+00 & 0.00000 \mathrm{E}+00 & 5.91650 \mathrm{E}-02 & 0 .\end{array}$

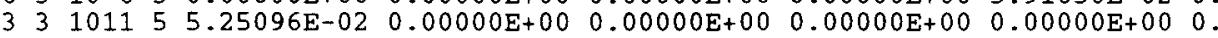

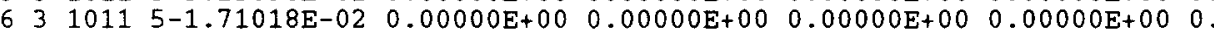

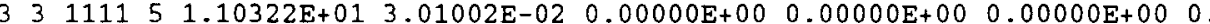

$\begin{array}{lllllllll}63 & 3111 & 5 & 4.10503 \mathrm{E}-02-9.94901 \mathrm{E}-03 & 0.00000 \mathrm{E}+00 & 0.00000 \mathrm{E}+00 & 0.00000 \mathrm{E}+00 & 0 .\end{array}$

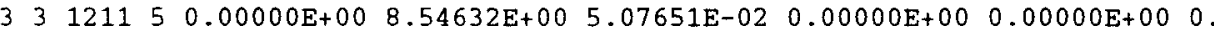

$\begin{array}{llllllllll}6 & 3 & 1211 & 5 & 0.00000 \mathrm{E}+00 & 4.10533 \mathrm{E}-02-1.68388 \mathrm{E}-02 & 0.00000 \mathrm{E}+00 & 0.00000 \mathrm{E}+00 & 0\end{array}$

$\begin{array}{llllllllll}3 & 3 & 1311 & 5 & 0.00000 \mathrm{E}+00 & 0.00000 \mathrm{E}+00 & 9.73836 \mathrm{E}+00 & 1.14013 \mathrm{E}-01 & 0.00000 \mathrm{E}+00 & 0 .\end{array}$

$\begin{array}{lllllllll}6 & 3 & 1311 & 5 & 0.00000 \mathrm{E}+00 & 0.00000 \mathrm{E}+00 & 6.54752 \mathrm{E}-02-3.77611 \mathrm{E}-02 & 0.00000 \mathrm{E}+00 & 0 .\end{array}$

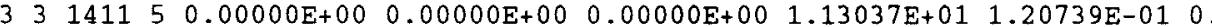

$\begin{array}{llllllllll}6 & 3 & 1411 & 5 & 0.00000 \mathrm{E}+00 & 0.00000 \mathrm{E}+00 & 0.00000 \mathrm{E}+00 & 7.17292 \mathrm{E}-02-3.96028 \mathrm{E}-02 & 0\end{array}$

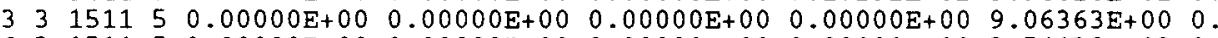

$\begin{array}{llllllllll}63 & 15115 & 0.00000 \mathrm{E}+00 & 0.00000 \mathrm{E}+00 & 0.00000 \mathrm{E}+00 & 0.00000 \mathrm{E}+00 & 2.54138 \mathrm{E}-02 & 0 .\end{array}$

$33161617.84331 \mathrm{E}+00 \quad 0.00000 \mathrm{E}+000.00000 \mathrm{E}+00 \quad 0.00000 \mathrm{E}+00 \quad 0.00000 \mathrm{E}+000$

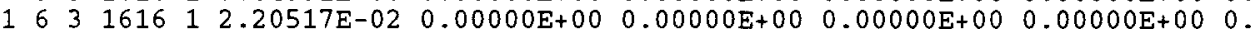


Listing 37. Table 1 Case 9, scakp input using Bansen-Roach crose sections.

LIMIT

LOWGRAPH PU $=0.0 \frac{1}{\mathrm{G}} / 16$; $\quad$ VF $\mathrm{GRA}=1.0$

$\begin{array}{rrr}1 & 13 & 0 \\ 19 & 1 & 999\end{array}$

$\begin{array}{rrrrr}1 & 1 & 1 & 1 \\ 1 & 1 & 1 & 1 & 1 \\ 1 & 1 & 2 & 616 & 8\end{array}$

$\begin{array}{lll}1 & 1 & .001\end{array}$

$\begin{array}{llll}1 & 2 & 1 & 001 \\ 1 & 1 & 100\end{array}$

$\begin{array}{lllll}1 & 1 & 1 & 5 & 1.0\end{array}$

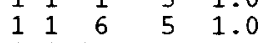

$\begin{array}{lllll}1 & 1 & 11 & 5 & 1.0\end{array}$

$\begin{array}{lllll}1 & 1 & 16 & 1 & 1.0\end{array}$

$\begin{array}{lllll}1 & 2 & 1 & 5 & 1.0\end{array}$

$\begin{array}{lllll}1 & 2 & 6 & 5 & 1.0\end{array}$

$\begin{array}{lllll}1 & 2 & 11 & 5 & 1.0\end{array}$

1216

$\begin{array}{lll}5 & 1 & 1\end{array}$

11.0

$5 \quad .225$

1.013

11111

LOWGRAPH PU $12 \quad \mathrm{PU}=0.04 \mathrm{G} / \mathrm{lb} ; \mathrm{VF}$ GRA $=1.0 \quad \mathrm{WVF}=0$

1.0

1.0

1.0
1.0

1.0

1.0

1.0

1.0
1.0

1.0

.161

.347

0.080233

$\begin{array}{rrrrrrr}1 & 1 & 1 & 1 & 2 & 616 & 8\end{array}$

$1111123.555-7$

LOWGRAPH $P U=0.03 \mathrm{G} / \mathrm{lb} ; \mathrm{VF}$ GRA $=1.0 \quad \mathrm{WVF}=0$

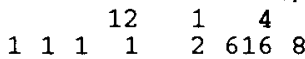

$1111122.666-7$

0.080233

LOWGRAPH $P U=0.02 \mathrm{G} / 1 \mathrm{~b} ; \mathrm{VF}$ GRA $=1.0 \quad \mathrm{WVF}=0$

$\begin{array}{rrrrrrrr} & & 1 & 12 & 1 & 4 & \\ 1 & 1 & 1 & 2 & 616 & 8\end{array}$

$\begin{array}{lllll}111 & 1 & 1 & 2 & 1.777-7\end{array}$

0.080233

LOWGRAPH PU $=0.01 \mathrm{G} / \mathrm{lb}$; VF GRA $=1$. 0 WVF $=0$

$\begin{array}{rrrrrrr} & & 1 & 12 & 1 & 4 & \\ 1 & 1 & 1 & 1 & 616 & 8\end{array}$

$\begin{array}{llllll}111 & 1 & 1 & 2 & 8.887-8\end{array}$

0.080233
1

$\begin{array}{ll}1.0 & 1.0 \\ 1.0 & 1.0 \\ 1.0 & 1.0 \\ 1.0 & 1.0 \\ 1.0 & 1.0 \\ 1.0 & 1.0 \\ .170 & .084\end{array}$

1

1

1 
Ilsting 38. Table 1 Case 9, KrNo-v.a Input using Hansen-Roach crose sections.

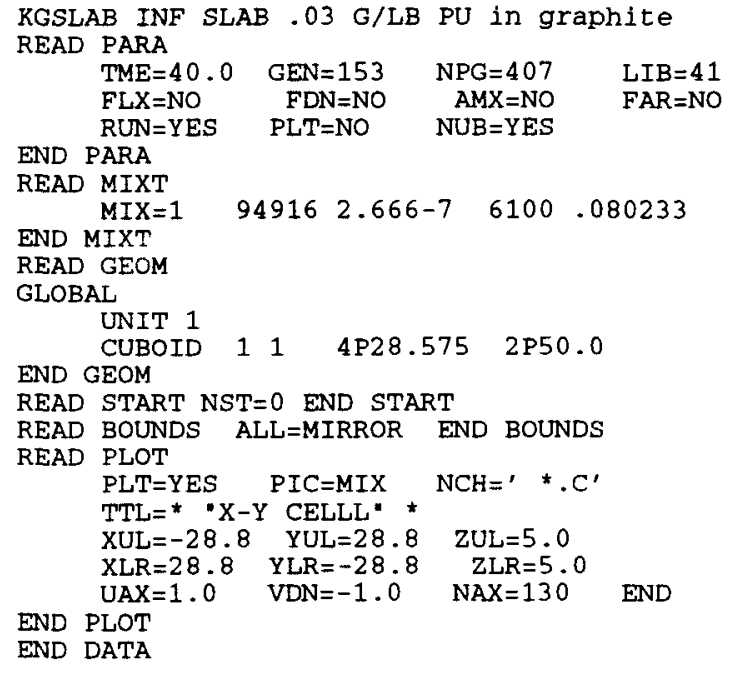

Ilsting 39. Table 1 Case 9, Krwo-V.a input using CSAs and 27-group cross sections. 
Liating 41. Table 5 case 5, KENO-V.a input.

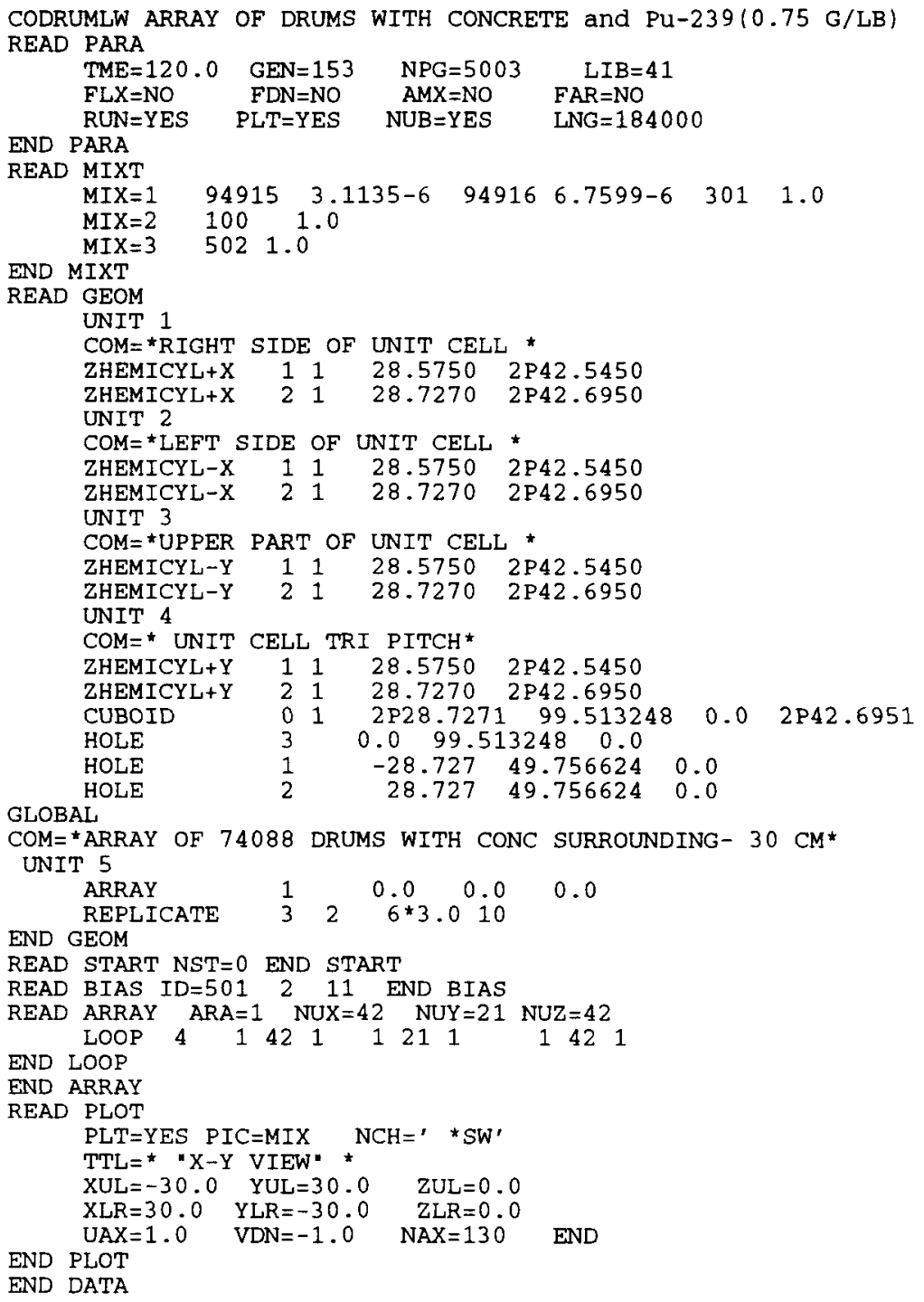


Ilsting 42. Table 5 case 8, Kswo-v. Input.

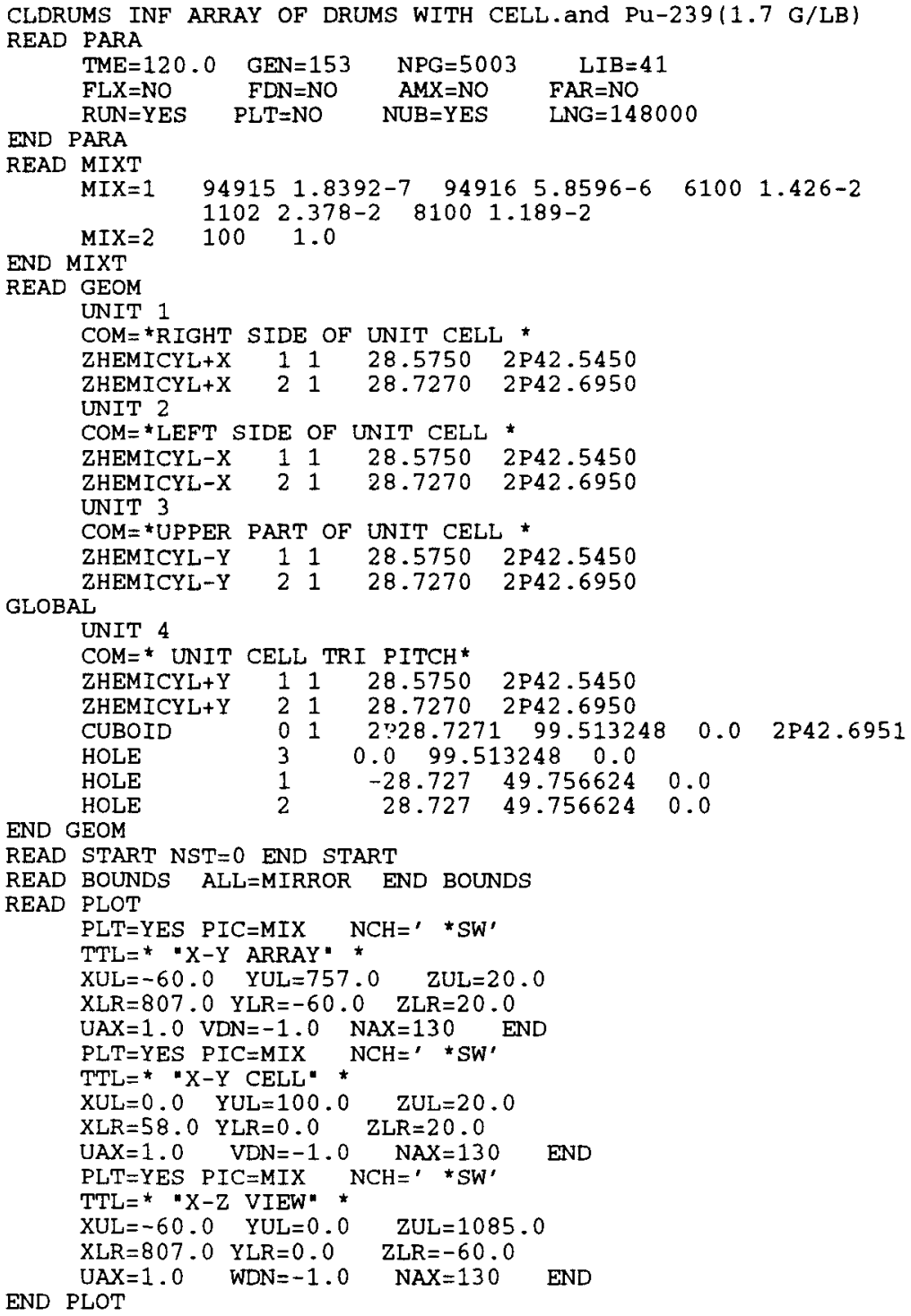


Liating 43. Table 5 Case 12, KrNo-v. a input.

SLABG2 INF SLAB $0.5 \mathrm{G} / \mathrm{LB}$ PU in graphite

READ PARA

TME $=40.0 \quad$ GEN $=153 \quad \mathrm{NPG}=407 \quad \mathrm{LIB}=41$

FLX $=$ NO FDN $=$ NO $\quad A M X=N O \quad F A R=N O$

END PARA

RUN=YES PLT $=$ NO NUB=YES

READ MIXT

$M I X=1 \quad 94915 \quad 1.37298-6 \quad 94916 \quad 3.07102-6 \quad 6100 \quad .080233$

EAD GEOM

GLOBAL

UNIT 1

CUBOID 1114 4P28.575 2P50.0

END GEOM

READ START NST $=0$ END START

READ BOUNDS ALL=MIRROR END BOUNDS

READ PLOT

PLT=YES PIC $=$ MIX NCH $={ }^{\prime} * \mathrm{C}^{\prime}$

TTL $=$ * "X-Y CELLL" *

$\mathrm{XUL}=-28.8 \quad$ YUL $=28.8 \quad \mathrm{ZUL}=5.0$

$\mathrm{XLR}=28.8 \quad \mathrm{YLR}=-28.8 \quad \mathrm{ZLR}=5.0$

END PLOT

$\mathrm{UAX}=1.0 \quad \mathrm{VDN}=-1.0 \quad \mathrm{NAX}=130^{\circ} \quad$ END

END DATA

Ifating 44. Table 5 Case 16, KawO-V.a input.

DRUMSG1 INF ARRAY OF DRUMS WITH 1 G/LB PU

READ PARA

TME $=40.0 \quad$ GEN $=153 \quad \mathrm{NPG}=407 \quad \mathrm{LIB}=4$

$F L X=N O \quad F D N=N O \quad A M X=N O \quad F A R=N O$

END PARA

RUN=YES PLT $=$ NO NUB $=$ YES

READ MIXT

MIX $=1 \quad 94914 \quad 7.6739-6 \quad 94915 \quad 1.2111-6 \quad 6100 \quad .080233$

MIX $=2 \quad 100 \quad 1.0$

END MIXT

$\operatorname{MIX}=3 \quad 402 \quad 1.0$

READ GEOM

UNIT 1

COM $=$ *RIGHT SIDE OF UNIT CELL *

ZHEMICYL+X $\quad \begin{array}{lllll}1 & 1 & 28.5750 & 2 \mathrm{P} 42.5450\end{array}$

ZHEMICYL+X $\quad 2 \quad 1 \quad 28.7270 \quad 2842.6950$

UNIT 2

COM $={ }^{*}$ LEFT SIDE OF UNIT CELL *

ZHEMICYL-X $\quad 1 \quad 1 \quad 28.5750 \quad 2 \mathrm{P} 42.5450$

ZHEMICYL-X $\quad 21 \quad 28.7270 \quad 2$ P42.6950

UNIT 3

COM $=$ *UPPER PART OF UNIT CELT *

$\begin{array}{lcclll}\text { ZHEMICYL-Y } & 1 & 1 & 28.5750 & 2 \mathrm{P} 42.5450\end{array}$

GLOBAL

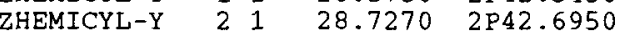

UNIT 4

COM $=$ * UNIT CELL TRI PITCH *

ZHEMICYL+Y $11128.5750 \quad 2 \mathrm{P} 42.5450$

ZHEMICYL+Y $\quad 2 \quad 1 \quad 28.7270 \quad 2 P 42.6950$

$\begin{array}{lllllll}\text { CUBOID } & 0 & 1 & 2 \mathrm{P} 28.727001 & 99.513248 & -0.0 & 2 \mathrm{P} 42.6950\end{array}$

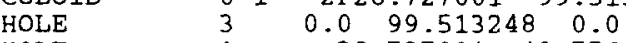

$\begin{array}{llllll}\text { HOLE } & 1 & -28.727001 & 49.756624 & 0.0\end{array}$

TND

$28.727001-49.756624 \quad 0.0$

READ START NST $=0$ END START

READ BOUNDS ALL=MIRROR END BOUNDS

READ PLOT

PLT=YES PIC=MIX $\mathrm{NCH}=$ ' *. $\mathrm{C}^{\prime}$

TTL $=$ * "X-Y CELLL" *

XUL $=-28.8 \quad$ YUL $=49.8 \quad$ ZUL $=25.0$

$X L R=28.8 \quad$ YLR $=-49.8 \quad \mathrm{ZLR}=25.0$

END PLOT

$\mathrm{UAX}=1.0 \quad \mathrm{VDN}=-1.0^{\circ} \mathrm{NAX}=130^{\circ}$ END

END DATA 
Listing 45. Table 5 Case 19 , KEro-v. a Input.

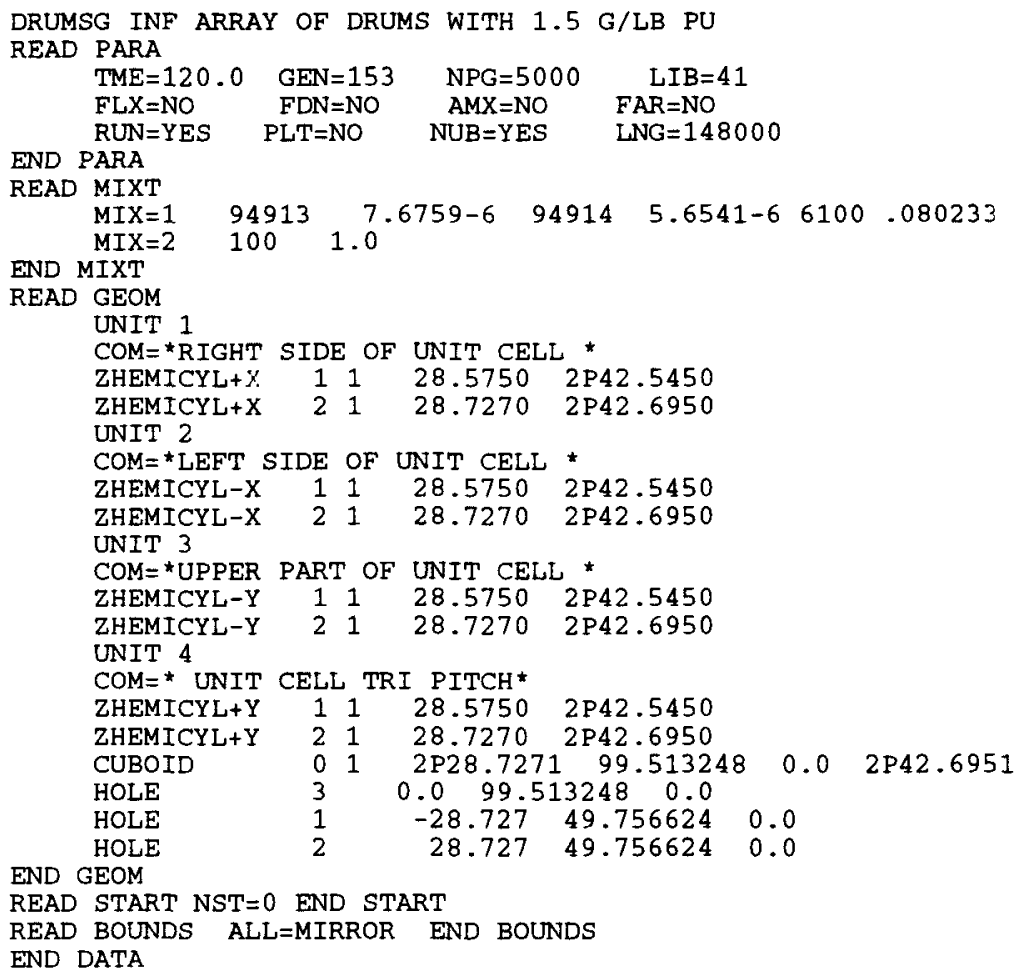


Listing 46. Table 6 Case 6, Krwo-v.a input.

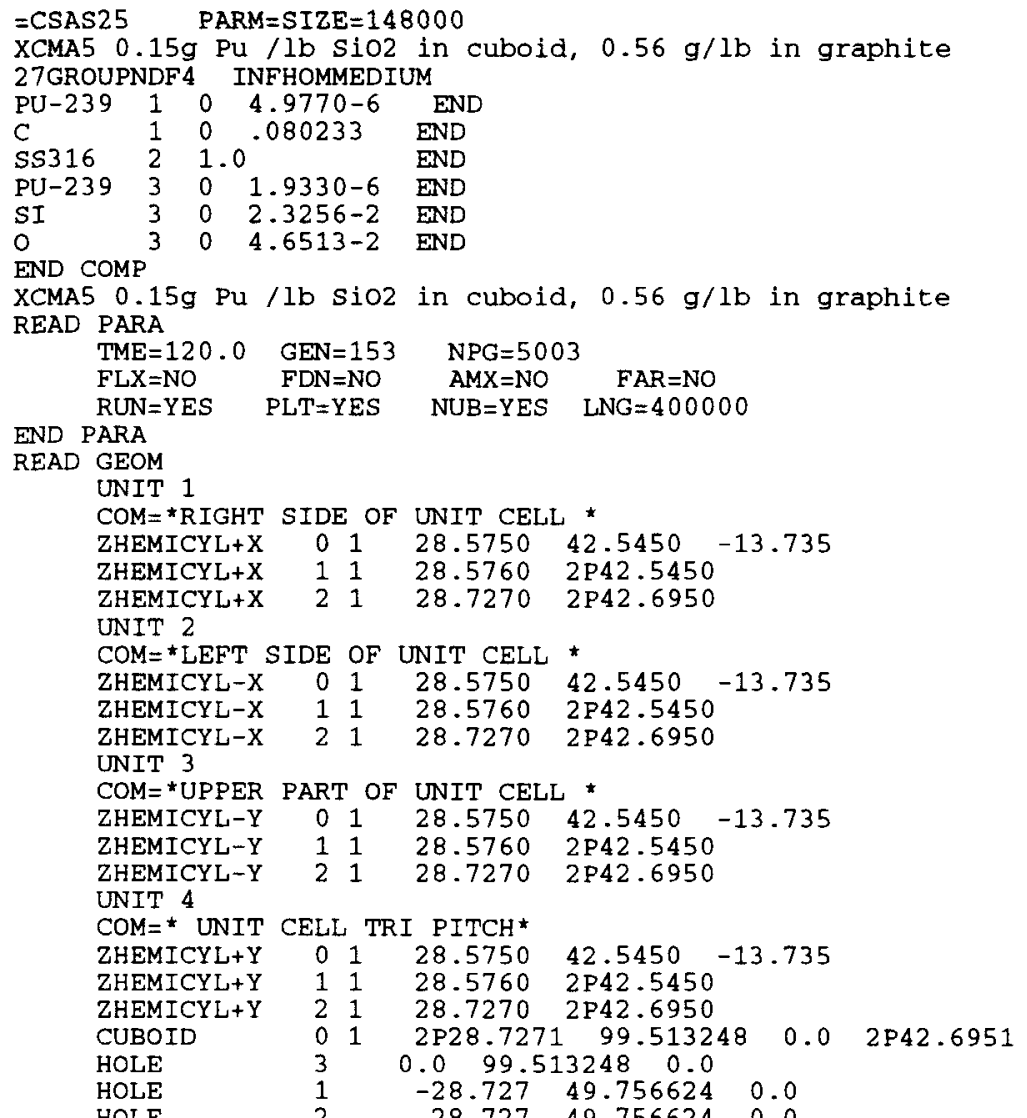


Listing 47. Table 9 Case 9, 5 drum high KBNO-v.a Input.

$=\operatorname{CSAS} 25$

CS95W5 INF SLAB .15 G/LB PU in SiO2/H20, 5hi

27GROUPNDF4 INFHOMMEDIUM

PU-239 1 1 0 1.9330-6 END

SI $11002.2094-2$ END

O $11004.4187-2$ END

$\begin{array}{lllll}\mathrm{H} 2 \mathrm{O} & & 1 & 0.05 & \text { END } \\ \mathrm{H} & 2 & 0 & 0.014868 & \text { END }\end{array}$

$\begin{array}{lllll}\mathrm{H} & 2 & 0 & 0.014868 & \text { END } \\ \mathrm{C} & 2 & 0 & 0.003814 & \text { END }\end{array}$

$\begin{array}{lllll}0 & 2 & 0 & 0.041519 & \text { END }\end{array}$

$\begin{array}{lllll}C A & 2 & 0 & 0.011588 & \text { END }\end{array}$

SI $2000.006037 \quad$ END

FE $2 \quad 0 \quad 0.0001968$ END

AL $2 \quad 0 \quad 0.000735$ END

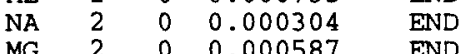

END COMP

CS95W5 INF SLAB .15 G/LB PU in SiO2/H20, 5hi

READ PARA

$T M E=40.0 \quad G E N=153 \quad N P G=1000$

$F L X=N O \quad F D N=N O \quad A M X=N O \quad F A R=N O$

END PARA

RUN $=$ YES $\quad P L T=N O \quad N U B=Y E S$

READ GEOM

GLOBAL

UNIT 1

CUBOID $\quad 11 \quad 4$ P28.575 2P213.475

END GEOM

REPLICATE $22 \quad 4 * 0.02 * 5.06$

READ START NST $=0$ END START

READ BOUNDS XYF=MIRROR END BOUNDS

READ BIAS ID $=30127$ END BIAS

READ PLOT

PLT=YES PIC=MIX NCH ${ }^{\prime}$ *. $\mathrm{C}^{\prime}$

TTL = * "X-Y VIEW" *

$X U L=-28.8 \quad$ YUL $=28.8 \quad$ ZUL $=5.0$

$X L R=28.8 \quad Y L R=-28.8 \quad Z L R=5.0$

$\mathrm{UAX}=1.0 \quad \mathrm{VDN}=-1.0 \quad \mathrm{NAX}=130$ END

END PLOT

END DATA

Listing 48. Table 9 Case 9, fully infinite, KENO-V.a input.

$=\operatorname{CSAS} 25$

CS95W5 (i50g) INF SLAB . $15 \mathrm{G} / \mathrm{LB}$ PU in SiO2/H20

27GROUPNDF4 INFHOMMEDIUM

PU-239 $1001.9330-6$ END

SI $\quad 1 \quad 0 \quad 2.2094-2$ END

$0 \quad 1 \quad 0 \quad 4.4187-2$ END

$\begin{array}{llll}\mathrm{H} 2 \mathrm{O} & 1 & 0.05 & \end{array}$

CS95W5 (i50g) INF SLAB . $15 \mathrm{G} / \mathrm{LB}$ PU in SiO2/H20

READ PARA

$\begin{array}{llll}\text { TME }=40.0 & \text { GEN }=153 & \text { NPG }=1000 & \\ \text { FLX }=\text { NO } & \text { FDN }=\text { NO } & \text { AMX }=\text { NO } & \text { FAR }=\text { NO }\end{array}$

END PARA

$F D N=N O \quad A M X=N O \quad F A R=N O$

READ GEOM

GLOBAL

UNIT 1

$\begin{array}{llll}\text { UNIT } 1 & 1 & 4 \mathrm{P} 28.575 & 2 \mathrm{P} 50.0\end{array}$

END GEOM

READ START NST $=0$ END START

READ BOUNDS ALL=MIRROR END BOUNDS

READ PLOT

PLT $=$ YES PIC=MIX $\mathrm{NCH}={ }^{\prime} * . \mathrm{C}^{\prime}$

TTL $=$ * $\cdot \mathrm{X}-\mathrm{Y}$ VIEW" *

$\mathrm{XUL}=-28.8 \quad$ YUL $=28.8 \quad \mathrm{ZUL}=5.0$

$\mathrm{XLR}=28.8 \quad \mathrm{YLR}=-28.8 \quad \mathrm{ZLR}=5.0$

END PLOT

UAX $=1.0 \quad \mathrm{VDN}=-1.0 \quad \mathrm{NAX}=130 \quad$ END

END DATA 
Lieting 49. Table 9 Case 12, 5 drum high, Kawo-v. Input.

\section{$=\operatorname{CSAS} 25$}

CS92W8 INF SLAB .15 G/LB PU in SiO2/H20, 5hi 27GROUPNDF4 INFHOMMEDIUM

PU-239 1 o $1.9330-6$ END

SI $\quad 1 \quad 0 \quad 2.1396-2$ END

$0 \quad 11004.2792-2$ END

$\mathrm{H} 2 \mathrm{O} \quad 1 \quad 0.08 \quad$ END

$\begin{array}{lllll}\mathrm{H} & 2 & 0 & 0.014868 \quad \text { END }\end{array}$

$\begin{array}{lllll}C & 2 & 0 & 0.003814 & \text { END } \\ 0 & 2 & 0 & 0.041519 & \text { END }\end{array}$

$\begin{array}{lllll} & & 2 & 0 & 0.011588\end{array}$

$\begin{array}{lllll}\text { SI } & 2 & 0 & 0.006037 & \text { END }\end{array}$

FE 2000001968 END

AL $200.000735 \quad$ END

$\begin{array}{llllll}\text { NA } & 2 & 0 & 0.000304 & \text { END }\end{array}$

$\begin{array}{lccc}M G & 2 & 0 & 0.000587\end{array}$

CS92W8 INF SLAB . $15 \mathrm{G} / \mathrm{LB}$ PU in SiO2/H20, 5hi

READ PARA

TME $=40.0 \quad$ GEN $=153 \quad \mathrm{NPG}=1000$

$F L X=N O \quad F D N=N O \quad A M X=N O \quad F A R=N O$

END PARA

RUN=YES PLT=NO NUB=YES $\quad$ FAR=NO

READ GEOM

GLOBAL

UNIT 1

CUBOID $\quad \begin{array}{llll}1 & 1 & 4 \mathrm{P} 28.575 & 2 \mathrm{P} 213.475\end{array}$

REPLICATE $22 \quad 4 * 0.02 * 5.06$

END GEOM

READ START NST $=0$ END START

READ BOUNDS XYF=MIRROR END BOUNDS

READ BIAS ID $=30127$ END BIAS

READ PLOT

PLT $=$ YES PIC $=\mathrm{MIX} \quad \mathrm{NCH}=$ ' *. $\mathrm{C}^{\prime}$

TTL $=$ * "X-Y VIEW" *

$\mathrm{XUL}=-28.8 \quad$ YUL $=28.8 \quad$ ZUL $=5.0$

$X L R=28.8 \quad Y L R=-28.8 \quad \mathrm{ZLR}=5.0$

$\mathrm{UAX}=1.0 \quad \mathrm{VDN}=-1.0 \quad \mathrm{NAX}=130^{\circ} \quad$ END

END PLOT

END DATA 
L1sting 50. Table 10 All Cases, schup Input.

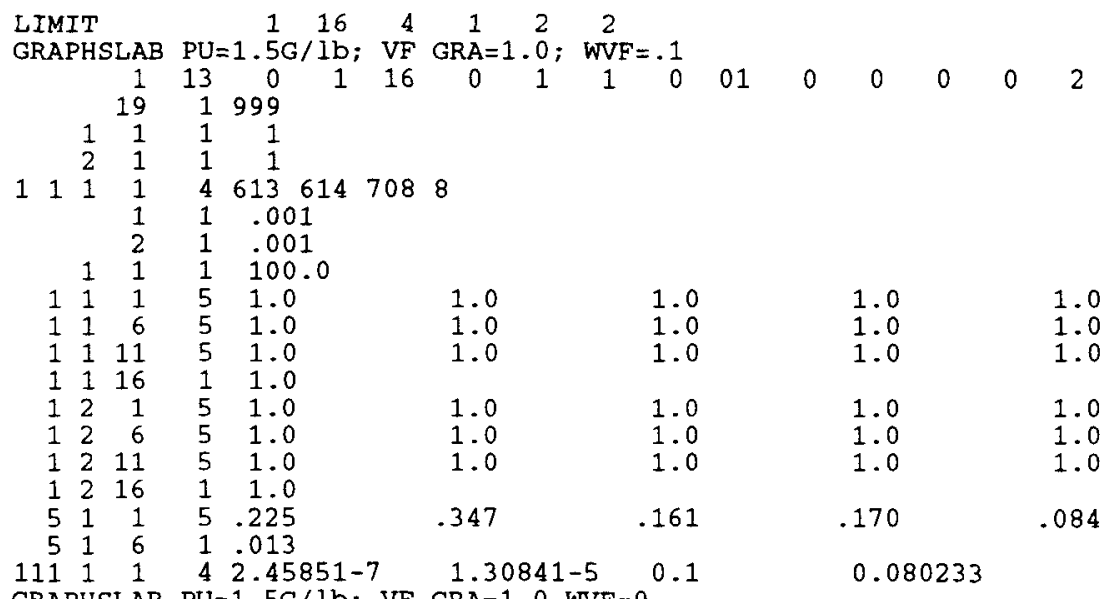


Listing 51. Table 11 case 2, KRNo-v. Input.

$=$ CSAS $25 \quad$ PARM $=$ SIZE $=153000$

CCSAM 3 PU at 758 of Crit $\mathrm{C}(.02) / \mathrm{SiO} 2(.15) / \mathrm{AlO} 2(.23) / \mathrm{MgO}(.10)$

27GROUPNDF 4 INFHOMMEDIUM

PU-239 $11001.7775-7$ END

C $\quad 1 \quad 0 \quad 8.0233-2$ END

PU-239 $2001.9330-6$ END

SI $20002.3256-2$ END

$\begin{array}{llll}0 & 2 & 0 & 4.6513-2 \\ \text { END }\end{array}$

PU-239 $3 \quad 0 \quad 5.0656-6$ END

$\mathrm{AL} \quad 3 \quad 0 \quad 4.6844-2$ END

$\begin{array}{lllll}0 & 3 & 0 & 7.0266-2 & \text { END }\end{array}$

PU-239 4 4 0 1.9887-6 END

MG $4 \quad 4 \quad 0 \quad 5.3499-2$ END

$\begin{array}{lllll}0 & 4 & 0 & 5.3499-2 & \text { END }\end{array}$

CCSAM3 PU at $75 \%$ of crit $\mathrm{C}(.02) / \mathrm{SiO} 2(.15) / \mathrm{AlO} 2(.23) / \mathrm{MgO}(.10)$

READ PARA

TME $=200.0 \quad$ GEN $=153 \quad \mathrm{NPG}=3003$

$F L X=N O \quad F D N=N O \quad A M X=N O \quad F A R=N O$

END PARA

READ GEOM

UNIT 1

CUBOID 1114 4P28.575 2 P25.0

UNIT 2

$\begin{array}{lllll}\text { CUBOID } & 2 & 1 & 4 \mathrm{P} 28.575 & 2 \mathrm{P} 50.0\end{array}$

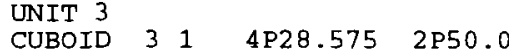

UNTT 4

CUBOID 414 P $28.575 \quad 2$ P25.0

GLOBAL COM='Array of 4 layers $(50 \mathrm{~cm})$ of $\mathrm{Pu}$ in different waste mixtures' UNIT

END GEOM

$\begin{array}{lllll}\text { ARRAY } & 1 & 0.0 & 0.0 & 0.0\end{array}$

READ START NST $=0$ END START

READ ARRAY

$A R A=1 \quad N U X=1 \quad N U Y=1 \quad N U Z=4$

FILL $\begin{array}{llllllll}1 & 2 & 3 & 4 & \text { END FILL }\end{array}$

END ARRAY

READ START NST $=1$ END START

READ BOUNDS ALL=MIRROR END BOUNDS

READ PLOT

PLT=YES PIC $=$ MIX $\mathrm{NCH}=$ * *. $\mathrm{C}^{\prime}$

TTL $=$ * "X-Y VIEW" *

XUL $=-28.8 \quad$ YUL $=28.8 \quad \mathrm{ZUL}=5.0$

$\mathrm{XLR}=28.8 \quad \mathrm{YLR}=-28.8 \quad \mathrm{ZLR}=5.0$

$\mathrm{UAX}=1.0 \quad \mathrm{VDN}=-1.0 \quad \mathrm{NAX}=130 \quad \mathrm{END}$

END PLOT

END DATA 
Ileting 52. Table 11 Case 9, scxur input.

LIMIT $\quad \begin{array}{llllll}1 & 16 & 3 & 1 & 2 & 2\end{array}$

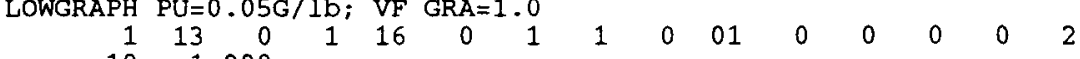

$\begin{array}{rrrrr}1 & 1 & 1 & 1 \\ 1 & 2 & 1 & 1 & 1\end{array}$

$\begin{array}{rrrrrr}1 & 1 & 1 & 2 & 616 & 8 \\ & 1 & 1 & .001\end{array}$

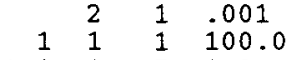

$\begin{array}{lllll}1 & 1 & 1 & 5 & 1.0\end{array}$

$\begin{array}{lllll}1 & 1 & 6 & 5 & 1.0\end{array}$

$\begin{array}{lllll}1 & 1 & 11 & 5 & 1.0\end{array}$

$\begin{array}{lllll}1 & 1 & 16 & 1 & 1.0\end{array}$

$\begin{array}{lllll}1 & 2 & 1 & 5 & 1\end{array}$

$\begin{array}{lllll}1 & 2 & 6 & 5 & 1.0\end{array}$

$\begin{array}{lllll}1 & 2 & 11 & 5 & 1.0\end{array}$

$\begin{array}{lll}1 & 2 & 16\end{array}$

$\begin{array}{lllll}5 & 1 & 1 & 5 & 225\end{array}$

$\begin{array}{lllll}5 & 1 & 6 & 1 & .013\end{array}$

$1111 \quad 1 \quad 2 \quad 4.444-7$

$$
\begin{aligned}
& 1.0 \\
& 1.0 \\
& 1.0 \\
& 1.0 \\
& 1.0 \\
& 1.0
\end{aligned}
$$

1.0

1.0

1.0
1.0

1.0

1.0

1.0

1.0

1.0

1.0

.347

.161

.170

1.0

1.0
1.0
1.0

0.080233

LOWGRAPH PU $=0.04 \mathrm{G} / \mathrm{lb} ; \mathrm{VF} \quad \mathrm{GRA}=1.0 \quad \mathrm{WVF}=0$

$\begin{array}{rrrrrr}1 & & 12 & 1 & 4 \\ 111 & 1 & 1 & 2 & 616 & 8 \\ 1 & 1 & 2 & 3.555-7\end{array}$

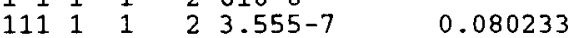

LOWGRAPH $P U=0.03 \mathrm{G} / \mathrm{lb} ; \mathrm{VF} \quad G R A=1.0 \quad \mathrm{WVF}=0$

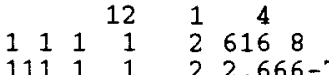

$1111122.666-7 \quad 0.080233$

LOWGRAPH PU $=0.02 \mathrm{G} / \mathrm{lb} ; \mathrm{VF} \quad \mathrm{GRA}=1.0 \mathrm{WVF}=0$

$\begin{array}{rrrrrrr}1 & 1 & 1 & 12 & 1 & 4 & \\ 1 & 1 & 1 & 2 & 616 & 8\end{array}$

LOWGRAPH PU $=0.01 \mathrm{G} / \mathrm{lb}$; VF $\mathrm{GRA}=1.0 \quad \mathrm{WVF}=0$

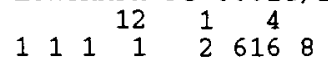

$\begin{array}{llllll}111 & 1 & 1 & 2 & 8.887-8 & 0.080233\end{array}$

Listing 53. Table 12 Case 1, scaMp input.

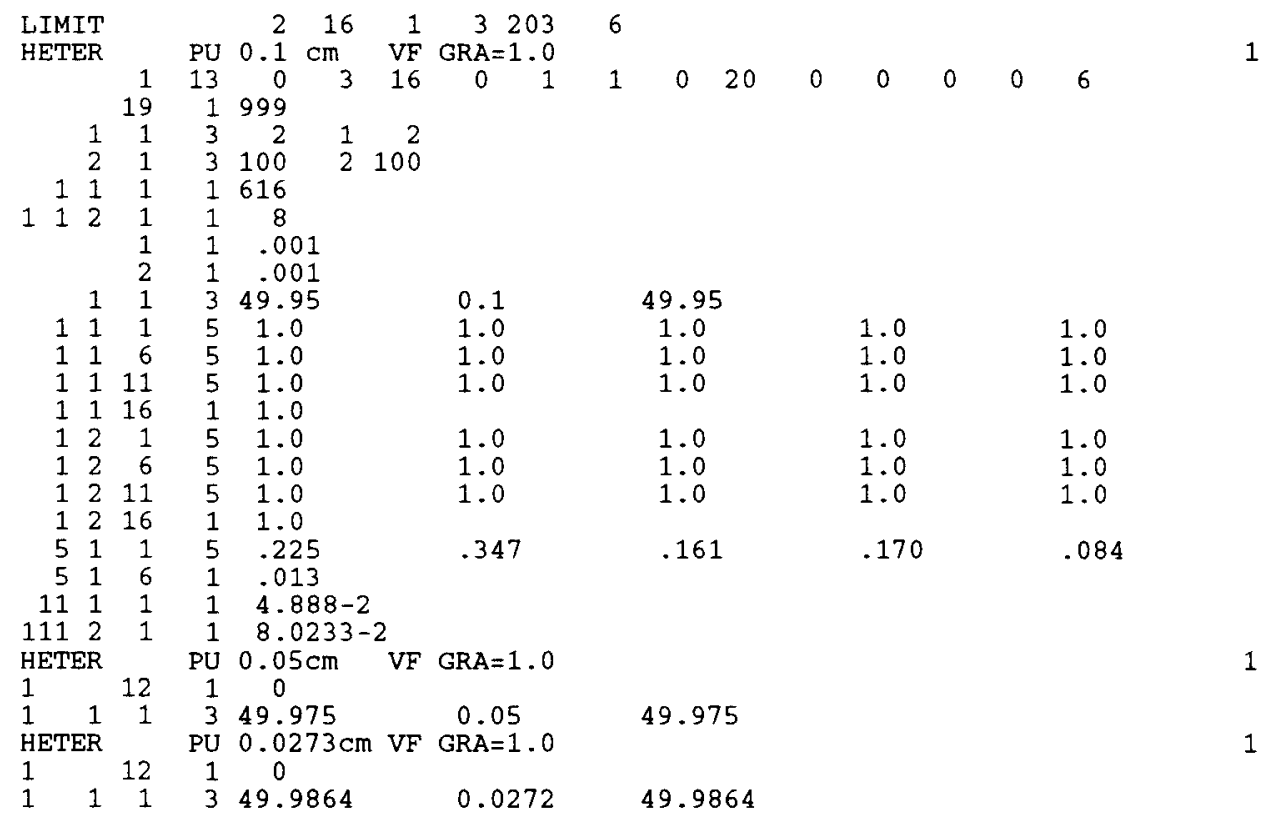


Listing 54. Table 12 Case 6, SCNMP Input.

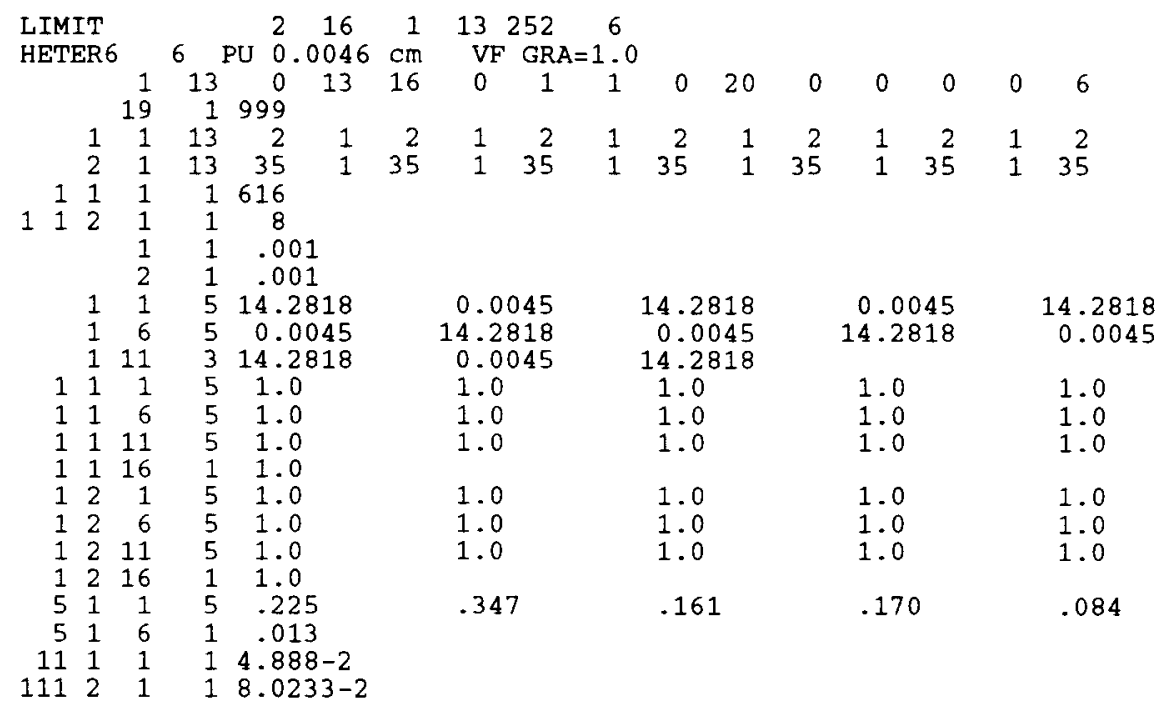


Llating 55. Table 13 case 2, KBro-v.a input.

DMGMXV INF ARRAY OF DRUMS WITH $1.5 \mathrm{G} / \mathrm{LB}$ PU, $C$ vol based on $260 \mathrm{lb}, 1.6 \mathrm{~g} / \mathrm{CC}$ READ PARA

$\begin{array}{llcl}\text { TME }=120.0 & \text { GEN }=153 & \text { NPG }=5000 & \text { LIB }=41 \\ \text { FLX }=\text { NO } & \text { FDN=NO } & \text { AMX=NO } & \text { FAR=NO } \\ \text { RUN=YES } & \text { PLT=NO } & \text { NUB }=\text { YES } & \text { LNG }=148000\end{array}$

END PARA

READ MIXT

$\begin{array}{lllllll}\text { MIX=1 } & 94913 & 7.6759-6 & 94914 & 5.6541-6 & 6100 & .080233\end{array}$

END MIXT

$\begin{array}{lllllll}\text { MIX }=2 & 100 & 1.0 & & & & \end{array}$

READ GEOM

UNIT 1

COM $=$ *RIGHT SIDE OF UNIT CELL *

$\begin{array}{llllll}\text { ZHEMICYL } \mathrm{X} & 0 & 1 & 28.5750 & 42.5450 & -13.735\end{array}$

ZHEMICYL+X $\quad 1 \quad 1 \quad 28.5750 \quad 2 \mathrm{P} 42.5450$

ZHEMICYL $+\mathrm{X} \quad 2 \quad 1 \quad 28.7270 \quad 2 \mathrm{P} 42.6950$

UNIT 2

COM=*LEFT SIDE OF UNIT CELL *

$\begin{array}{llllll}\text { ZHEMICYL-X } & 0 & 1 & 28.5750 & 42.5450 & -13.735\end{array}$

$\begin{array}{lllll}\text { ZHEMICYL-X } & 1 & 1 & 28.5750 & 2 \mathrm{P} 42.5450\end{array}$

ZHEMICYL-X $\quad 21128.7270 \quad 2$ P42.6950

UNIT 3

COM $=$ *UPPER PART OF UNIT CELL *

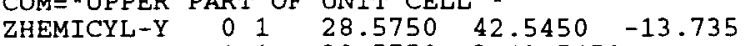

$\begin{array}{lllll}\text { ZHEMICYL-Y } & 1 & 1 & 28.5750 & 2 \mathrm{P} 42.5450\end{array}$

$\begin{array}{lllll}\text { ZHEMICYL-Y } & 2 & 1 & 28.7270 & 2 \mathrm{P} 42.6950\end{array}$

UNIT 4

COM=* UNIT CELL TRI PITCH *

$\begin{array}{llllll}\text { ZHEMICYL +Y } & 0 & 1 & 28.5750 & 42.5450 & -13.735\end{array}$

$\begin{array}{lllll}Z H E M I C Y L+Y & 1 & 1 & 28.5750 & 2 \mathrm{P} 42.5450\end{array}$

$\begin{array}{lllll}Z H E M I C Y L+Y & 2 & 1 & 28.7270 & 2 \mathrm{P} 42.6950\end{array}$

$\begin{array}{lllllll}\text { CUBOID } & 0 & 1 & 2 \mathrm{P} 28.7271 & 99.513248 & 0.0 & 2 \mathrm{P} 42.6951\end{array}$

$\begin{array}{lllll}\text { HOLE } & 3 & 0.0 & 99.513248 & 0.0\end{array}$

$\begin{array}{llrrr}\text { HOLE } & 1 & -28.727 & 49.756624 & 0.0\end{array}$

GLOBAL

UNIT 5

ARRAY

CUBOID

CUBOID

$\begin{array}{llll}1 & 0.0 & 0.0 & 0.0\end{array}$

END GEOM

$\begin{array}{lllllllllll}1 & 746.905 & 0.0 & 696.593 & 0.0 & 1024.683 & 0.0\end{array}$

READ START NST $=0$ END START

READ ARRAY ARA $=1 \quad$ NUX $=13 \quad \mathrm{NUY}=7 \quad \mathrm{NUZ}=12$

END LOOP

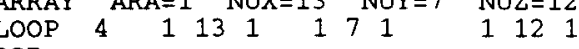

END ARRAY

READ BOUNDS ALL=MIRROR END BOUNDS

READ PLOT

PLT $=$ YES PIC $=$ MIX $\quad \mathrm{NCH}=\prime \quad$ "SW'

TTL $=$ * $\times-Y$-Y ARRAY" *

XUL $=-60.0 \quad$ YUL $=757.0 \quad$ ZUL $=20.0$

$X L R=807.0 \quad Y L R=-60.0 \quad$ ZLR $=20.0$

$\mathrm{UAX}=1.0 \quad \mathrm{VDN}=-1.0 \quad \mathrm{NAX}=130 \quad \mathrm{END}$

PLT $=$ YES PIC $=$ MIX NCH $=$ ' "SW"

TTL $=$ * "X-Y CELL" *

$\mathrm{XUL}=0.0 \quad$ YUL $=100.0 \quad \mathrm{ZUL}=20.0$

$X L R=58.0 \quad Y L R=0.0 \quad Z L R=20.0$

$\mathrm{UAX}=1.0 \quad \mathrm{VDN}=-1.0 \quad$ NAX $=130 \quad$ END

PLT $=$ YES PIC=MIX $\mathrm{NCH}=$ ' 'SW'

TTL $=$ * "X-Z VIEW" *

$\mathrm{XUL}=-60.0 \quad \mathrm{YUL}=0.0 \quad \mathrm{ZUL}=1085.0$

$\mathrm{XLR}=807.0 \quad \mathrm{YLR}=0.0 \quad \mathrm{ZLR}=-60.0$

END PLOT

UAX $=1.0 \quad$ WDN $=-1.0 \quad$ NAX $=130 \quad$ END

END DATA 
Listing 56. Table 13 Case 4, Kaxo-v. a Input.

DMD2 INF ARRAY OF DRUMS WITH $1.5 \mathrm{G} / \mathrm{LB}$ PU, C vol based on $260 \mathrm{lb}, .942 \mathrm{~g} / \mathrm{CC}$

READ PARA

TME $=120.0 \quad$ GEN $=153 \quad \mathrm{NPG}=5000 \quad \mathrm{LIB}=41$

FLX $=$ NO FDN=NO AMX $=$ NO $\quad F A R=N O$

END PARA

RUN $=$ YES PLT $=$ NO NUB $=$ YES LNG $=148000$

READ MIXT

$\begin{array}{lllllll}M I X=1 & 94913 & 4.52052-6 & 94914 & 3.32820-6 & 6100 & .0472373\end{array}$

END MIXT

READ GEOM

UNIT 1

COM $={ }^{*}$ RIGHT SIDE OF UNIT CELL *

$\begin{array}{llllll}\text { ZHEMICYL }+X & 0 & 1 & 28.5750 & 42.5450 & 6.265\end{array}$

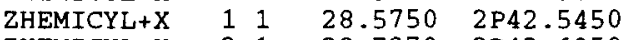

ZHEMICYL+X $\quad 21 \quad 28.7270 \quad 2$ P42.6950

UNIT 2

COM $={ }^{*}$ LEFT SIDE OF UNIT CELT *

$\begin{array}{llllll}\text { ZHEMICYL-X } & 0 & 1 & 28.5750 & 42.5450 & 6.265 \\ \text { ZHEMICYL-X } & 1 & 1 & 28.5750 & 2 \mathrm{P} 42.5450\end{array}$

$\begin{array}{lllll}\text { ZHEMICYL-X } & 2 & 1 & 28.7270 & 2 \mathrm{P} 42.6950\end{array}$

UNIT 3

COM $=$ *UPPER PART OF UNIT CELL *

ZHEMICYL-Y $001128.5750 \quad 42.5450 \quad 6.265$

$\begin{array}{lllll}\text { ZHEMICYL } Y & 1 & 1 & 28.5750 & 2 \mathrm{P} 42.5450\end{array}$

ZHEMICYL-Y $\quad 2 \quad 1 \quad 28.7270 \quad 2 \mathrm{P} 42.6950$

UNIT 4

COM $=$ * UNIT CELL TRI PITCH *

$\begin{array}{llllll}\text { ZHEMICYL+Y } & 0 & 1 & 28.5750 & 42.5450 & 6.265\end{array}$

$\begin{array}{lllll}\text { ZHEMICYL+Y } & 1 & 1 & 28.5750 & 2 \mathrm{P} 42.5450\end{array}$

ZHEMICYL $+Y \quad 21128.7270 \quad 2$ P42.6950

CUBOID

HOLE

$\begin{array}{lrrrr}\text { HOLE } & 1 & -28.727 & 49.756624 & 0.0 \\ \text { HOLE } & 2 & 28.727 & 49.756624 & 0.0\end{array}$

GLOBAL

UNIT 5

ARRAY

CUBOID

$\begin{array}{llll}1 & 0.0 & 0.0 & 0.0\end{array}$

$\begin{array}{lllllllll}0 & 1 & 746.905 & 0.0 & 696.593 & 0.0 & 1024.683 & 0.0\end{array}$

END GEOM

$\begin{array}{lllllllll}0 & 1 & 746.906 & -0.001 & 696.594 & -0.001 & 1024.684 & -0.001\end{array}$

READ START NST $=0$ END START

READ ARRAY ARA $=1 \quad$ NUX $=13 \quad$ NUY $=7 \quad N U Z=12$

END LOOP

$\begin{array}{lllllllll}\mathrm{ARA}=1 & \mathrm{NUX}=13 & \mathrm{NUY}=7 & \mathrm{NUZ}=12 \\ \text { LOOP } & 4 & 1 & 13 & 1 & 7 & 1 & 1 & 12\end{array}$

END ARRAY

READ BOUNDS ALL=MIRROR END BOUNDS

READ PLOT

PLT $=$ YES PIC $=$ MIX NCH $=\prime \quad$ *SW'

TTL $=$ * "X-Y ARRAY. *

$X U L=-60.0 \quad Y U L=757.0 \quad Z U L=5.0$

$X L R=807.0 \quad Y L R=-60.0 \quad$ ZLR $=5.0$

$\mathrm{UAX}=1.0 \quad \mathrm{VDN}=-1.0 \quad \mathrm{NAX}=130$ END

$\mathrm{PLT}=\mathrm{YES}$ PIC $=\mathrm{MIX} \mathrm{NCH}={ }^{\prime}{ }^{*} \mathrm{SW}$

TTL $=$ * "X X Y CELL" *

$\mathrm{XUL}=0.0 \quad$ YUL $=100.0 \quad \mathrm{ZUL}=5.0$

$\mathrm{XLR}=58.0 \quad \mathrm{YLR}=0.0 \quad \mathrm{ZLR}=5.0$

$\mathrm{UAX}=1.0 \quad \mathrm{VDN}=-1.0 \quad \mathrm{NAX}=130 \quad$ END

PLT $=$ YES $P I C=M I X \quad N C H=$ ' * $S W$ '

TTL $=$ * "X-Z VIEW" *

XUL $=-60.0 \quad$ YUL $=0.0 \quad$ ZUL $=1085.0$

$X L R=807.0 \quad Y L R=0.0 \quad Z L R=-60.0$

END PLOT

$\mathrm{UAX}=1.0 \quad \mathrm{WDN}=-1.0 \quad \mathrm{NAX}=130 \quad$ END

END DATA 
Listing 57. Table 14 Case 4b, Hoavily loaded drums with Mgo waste.

\begin{tabular}{|c|c|c|c|c|}
\hline & & & $M=S$ & \\
\hline NMCO35 & & $\frac{g o}{4}$ & - Compress & $d$ \\
\hline PU-239 & 1 & ${ }_{0}^{4}$ & INF HOMMEDI & ENI \\
\hline & 1 & 0 & & \\
\hline & 1 & 0 & & \\
\hline-239 & 2 & 0 & 2. & \\
\hline IG & $\overline{2}$ & 0 & & \\
\hline & 2 & 0 & & \\
\hline & & 0 & & \\
\hline$G$ & 3 & 0 & & \\
\hline & & 0 & & \\
\hline PU-239 & 4 & 0 & & \\
\hline 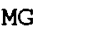 & 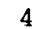 & 0 & & \\
\hline 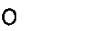 & 4 & 0 & & \\
\hline PU-239 & 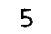 & 0 & 1 . & \\
\hline MG & 5 & 0 & & \\
\hline & 5 & 0 & 5. & \\
\hline PU- & 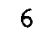 & & & \\
\hline MG & 6 & 0 & & \\
\hline & & & & \\
\hline PU-239 & 7 & 0 & 2 . & \\
\hline MG & & 0 & & \\
\hline 0 & 7 & 0 & 5. & \\
\hline PU- & 8 & 0 & & \\
\hline MG & 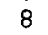 & 0 & 5. & \\
\hline 0 & & 0 & 5. & \\
\hline PU- & 9 & 0 & & \\
\hline SI & & 0 & & \\
\hline 0 & 9 & 0 & 4.65 & \\
\hline SS 304 & 10 & 1. & & \\
\hline
\end{tabular}

RWMC035 Mgo - Compressed Cube Model of Individual Heavily Loaded Drums READ PARA

TME $=350 \quad$ GEN $=253 \quad$ NPG $=2500$

$F L X=N O \quad F D N=N O \quad A M X=N O \quad F A R=N O$

END PARA

READ GEOM

UNIT 1

COM $=*$ MGO - CONCENTRATION $=2.03$ G PU/LB *

CUBOID $\quad 1116$ P 13.84660

CUBOID $\quad 10116$ 6P14.49113

UNIT 2

COM $=$ * MGO - CONCENTRATION $=1.34 \mathrm{G} \mathrm{PU/LB} \mathrm{*}$

CUBOID $\quad 2116$ PP13.84660

CUBOID $\quad 10116$ F14.49113

UNIT 3

COM $=$ * MGO - CONCENTRATION $=0.95 \mathrm{G} \mathrm{PU} / \mathrm{LB}$ *

CUBOID $\quad 3116 \mathrm{P} 13.84660$

CUBOID $\quad 1010614.49113$

UNIT 4

COM $=$ * MGO - CONCENTRATION $=0.74 \mathrm{G} \mathrm{PU} / \mathrm{LB}$ *

CUBOID $\quad 4116$ PP13.84660

CUBOID $\quad 101 \quad 6$ P14.49113

UNIT 5

COM $=$ * MGO - CONCENTRATION $=0.55 \mathrm{G}$ PU/LB *

CUBOID $\quad 5116$ 6 13.84660

CUBOID $\quad 10116$ 6P14.49113

UNIT 6

COM $=$ * MGO - CONCENTRATION $=0.24 \mathrm{G} \mathrm{PU} / \mathrm{LB}$ *

CUBOID $\quad 610$ 6P13.84660

CUBOID $\quad 10116$ PP14.49113

UNIT 7

COM = * MGO - CONCENTRATION=0.15 G PU/LB *

CUBOID $\quad 71$ 6P13.84660

CUBOID $\quad 101 \quad 6$ P 14.49113

UNIT 8

COM=* MGO - CONCENTRATION $=0.10 \mathrm{G} \mathrm{PU} / \mathrm{LB}$ *

CUBOID $\quad 81$ 6P13.84660

CUBOID $\quad 101 \quad 6$ P14.49113

UNIT 9

COM=* SIO2 - CONCENTRATION=0.15 G PU/LB *

CUBOID $\quad 91 \quad$ 6P13.84660

CUBOID $\quad 101 \quad 6 \mathrm{P} 14.49113$

GLOBAL 
Listing 57. Continued.

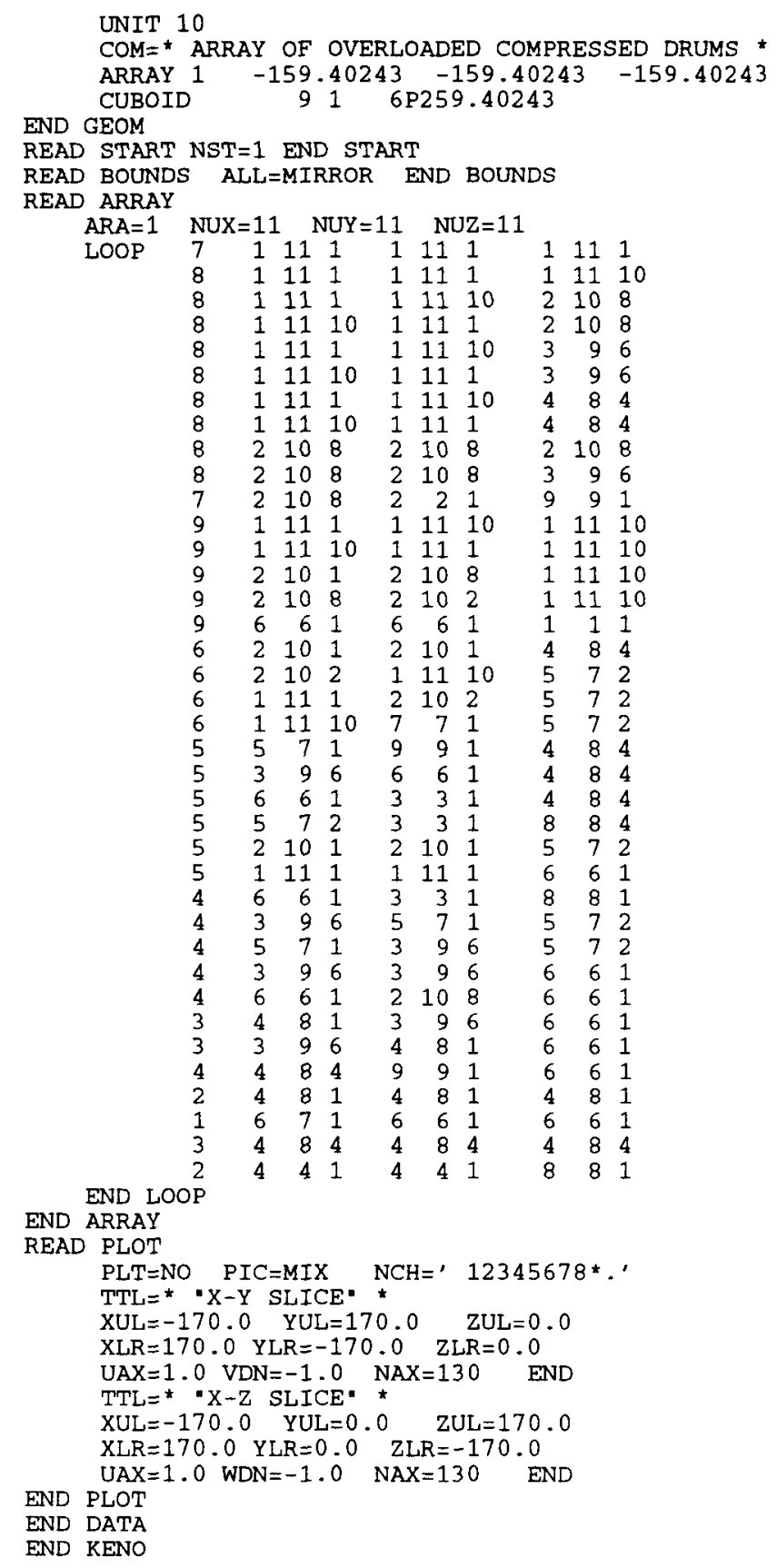


Ilsting 58. Table 14 Case Ac, Heavily loaded drum with Mgo waste. Double volume - half donsity.

\begin{tabular}{lllll} 
=CSAS25 & \multicolumn{5}{c}{ PARM=SIZE=153000 } \\
RWMC040 & \multicolumn{5}{c}{ RWMC033 with doubl } \\
27GROUPNDF 4 & INFHOMMEDIUM \\
PU-239 & 1 & 0 & $2.0184-5$ & END \\
MG & 1 & 0 & $2.6750-2$ & END \\
O & 1 & 0 & $2.6750-2$ & END \\
PU-239 & 2 & 0 & $1.3323-5$ & END \\
MG & 2 & 0 & $2.6750-2$ & END \\
O & 2 & 0 & $2.6750-2$ & END \\
PU-239 & 3 & 0 & $9.4455-6$ & END \\
MG & 3 & 0 & $2.6750-2$ & END \\
O & 3 & 0 & $2.6750-2$ & END \\
PU-239 & 4 & 0 & $7.3575-6$ & END \\
MG & 4 & 0 & $2.6750-2$ & END \\
O & 4 & 0 & $2.6750-2$ & END \\
PU-239 & 5 & 0 & $5.4685-6$ & END \\
MG & 5 & 0 & $2.6750-2$ & END \\
O & 5 & 0 & $2.6750-2$ & END \\
PU-239 & 6 & 0 & $2.3863-6$ & END \\
MG & 6 & 0 & $2.6750-2$ & END \\
O & 6 & 0 & $2.6750-2$ & END \\
PU-239 & 7 & 0 & $1.4914-6$ & END \\
MG & 7 & 0 & $2.6750-2$ & END \\
O & 7 & 0 & $2.6750-2$ & END \\
PU-239 & 8 & 0 & $9.9430-7$ & END \\
MG & 8 & 0 & $2.6750-2$ & END \\
O & 8 & 0 & $2.6750-2$ & END \\
PU-239 & 9 & 0 & $1.9330-6$ & END \\
SI & 9 & 0 & $2.3256-2$ & END \\
O & 9 & 0 & $4.6513-2$ & END \\
SS304 & 10 & 1.0 & & END \\
END $60 M P$ & & &
\end{tabular}

END COMP

RWMC040 RWMC033 with double volume and reduced atom densities READ PARA

$\begin{array}{lrrr}\text { TME }=350 & \text { GEN }=257 & \text { NPG }=2500 & \\ \text { FLX }=\text { NO } & \text { FDN=NO } & \text { AMX }=\text { NO } & \text { FAR }=\text { NO } \\ \text { RUN=YES } & \text { PLT }=\text { NO } & \text { NUB }=\text { YES } & \end{array}$

END PARA

READ GEOM

UNIT 1

COM $=$ * MGO - CONCENTRATION $=2.03 \mathrm{G}$ PU/LB *

CUBOID $\quad 1116$ 6P17.44562

CUBOID $\quad 101 \quad 6 P 17.86088$

UNIT 2

COM $=$ "MGO - CONCENTRATION=1.34 G PU/LB *

CUBO.. $\quad 21 \quad 6 P 17.44562$

CUBO:- $\quad 101$ 6P17.86088

UNIT 3

COM $=$ * MGO - CONCENTRATION $=0.95 \mathrm{G} \mathrm{PU} / \mathrm{LB}$ *

CUBOID $\quad 3116$ 6P17.44562

CUBOID $\quad 10116$ 6P17.86088

UNIT 4

$\mathrm{COM}=$ * $\mathrm{MGO}$ - CONCENTRATION $=0.74 \mathrm{G} \mathrm{PU} / \mathrm{LB}$ *

CUBOID $\quad 4116 \mathrm{P} 17.44562$

$\begin{array}{llll}\text { CUBOID } & 10 & 1 & 6 \mathrm{P} 17.86088\end{array}$

UNIT 5

$\mathrm{COM}=$ * MGO - CONCENTRATION $=0.55 \mathrm{G} \mathrm{PU} / \mathrm{LB}$ *

$\begin{array}{lll}\text { CUBOID } & 51 & 6 P 17.44562\end{array}$

CUBOID $\quad 10116$ P 17.86088

UNIT 6

COM = * MGO - CONCENTRATION $=0.24$ G PU/LB *

$\begin{array}{lccc}\text { CUBOID } & 61 & 6 \mathrm{P} 17.44562\end{array}$

CUBOID $\quad 10 \quad 1 \quad 6 P 17.86088$

UNIT 7

$\mathrm{COM}=$ * $\mathrm{MGO}$ - CONCENTRATION $=0.15 \mathrm{G} \mathrm{PU} / \mathrm{LB}$ *

CUBOID $\quad 71 \quad 6 \mathrm{P} 17.44562$

CUBOID $\quad 10116$ PP17.86088

UNIT 8

COM= * MGO - CONCENTRATION $=0.10 \mathrm{G} \mathrm{PU} / \mathrm{LB}$ *

CUBOID $\quad 81$ 6P17.44562

CUBOID $\quad 101 \quad 6 P 17.86088$

UNIT 9

COM = * SIO2 - CONCENTRATION $=0.15 \mathrm{G} \mathrm{PU} / \mathrm{LB}$ *

CUBOID $\quad 91 \quad 6 P 17.44562$

$\begin{array}{llll}\text { CUBOID } & 101 & 6 \mathrm{P} 17.86088\end{array}$ 
Liating 59. Table 14 Cace 5a, Krso-v.a input.

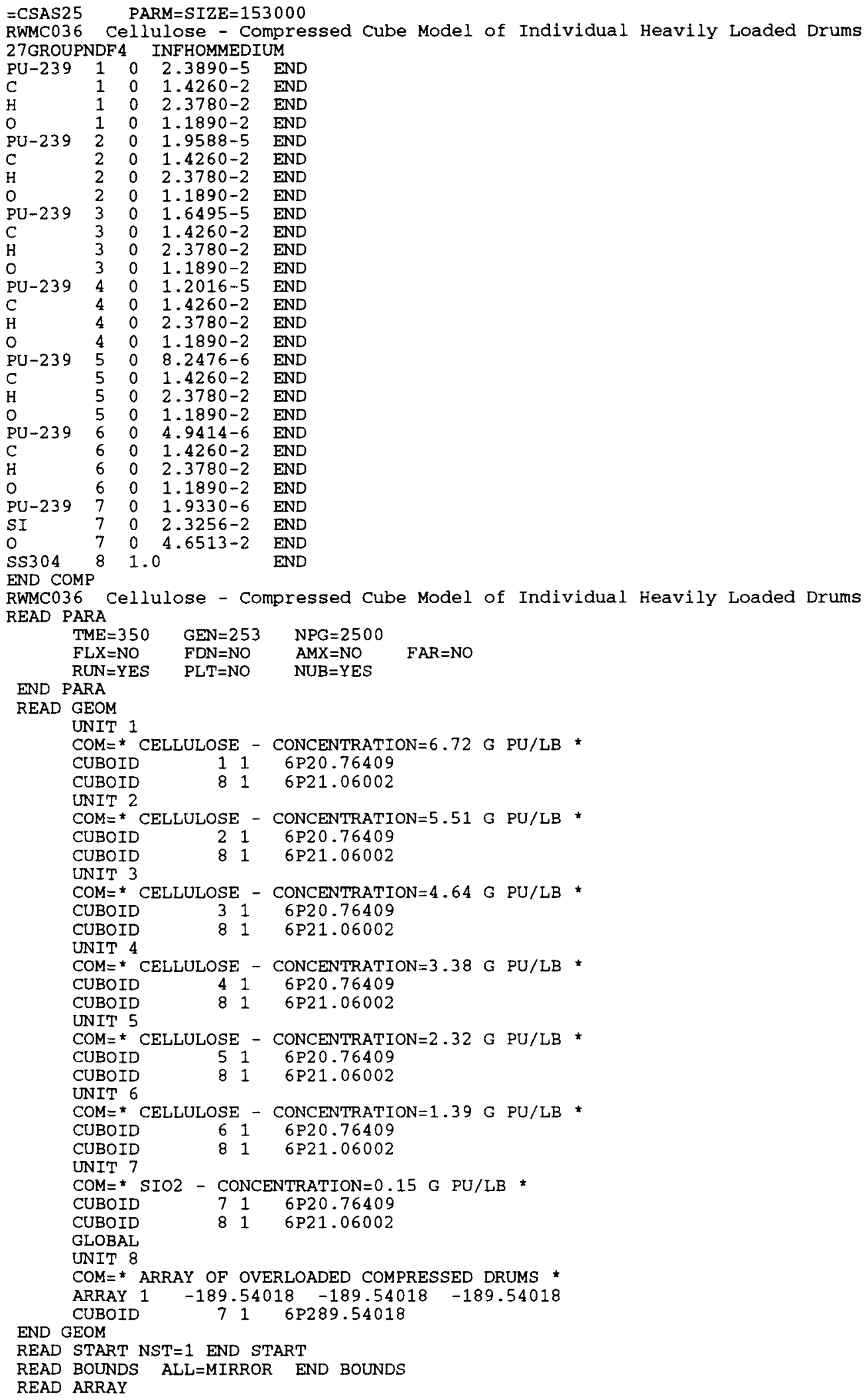


Listing 59. Continued.

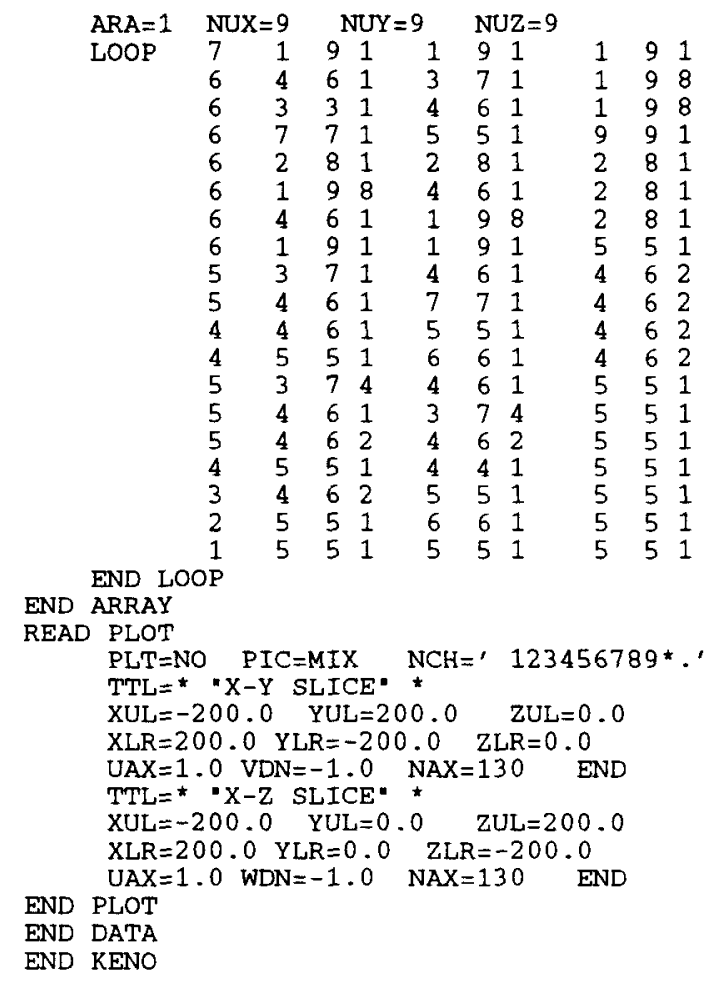


Listing 60. Table 14 case 5b, xawo-v.a Input.

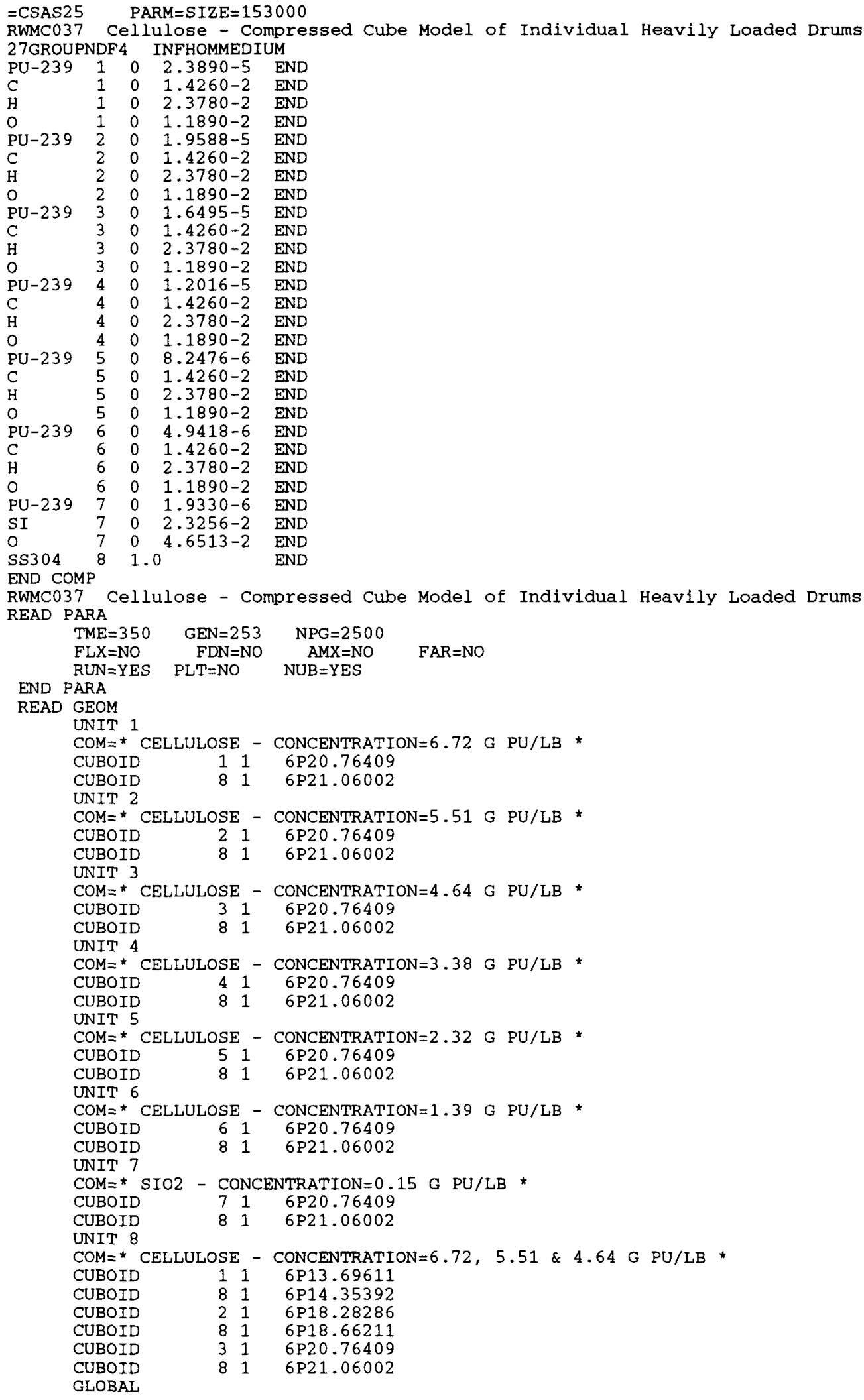


Lieting 60. Continued.

UNIT 9

COM $=$ * ARRAY OF OVERLOADED COMPRESSED DRUMS *

END GEO

$\begin{array}{llll} & -189.54018 & -189.54018 & -189.54018\end{array}$

READ START NST=1 END START

READ BOUNDS ALL=MIRROR END BOUNDS

READ ARRAY

$A R A=1 \quad N U X=9 \quad N U Y=9 \quad N U Z=9$

LOOP

END LOOP

\begin{tabular}{|c|c|c|c|c|c|}
\hline & NUT & & NUZ & & \\
\hline 1 & $\begin{array}{ll}91 \\
\end{array}$ & 1 & 91 & 1 & $\begin{array}{ll}9 & 1\end{array}$ \\
\hline 4 & 61 & 3 & 71 & 1 & 9 \\
\hline 3 & 31 & 4 & 61 & 1 & 98 \\
\hline 7 & & 5 & 51 & 9 & 91 \\
\hline 2 & 81 & 2 & 81 & 2 & 81 \\
\hline 1 & 98 & 4 & 61 & 2 & 8 \\
\hline 4 & 61 & 1 & 98 & 2 & \\
\hline 1 & 91 & 1 & 91 & 5 & 51 \\
\hline$A$ & & 4 & $\begin{array}{ll}6 \\
7\end{array}$ & 4 & \\
\hline 4 & 61 & 5 & 51 & 4 & 62 \\
\hline 5 & 51 & 6 & 61 & 4 & 62 \\
\hline 3 & 74 & 4 & 61 & 5 & \\
\hline 4 & 61 & 3 & 72 & 5 & 51 \\
\hline 4 & 62 & 4 & & 5 & $\begin{array}{ll}5 & 1\end{array}$ \\
\hline 5 & $\begin{array}{ll}5 & 1\end{array}$ & 4 & 4 & 5 & $\begin{array}{ll}5 & 1\end{array}$ \\
\hline 5 & 51 & 6 & 6 & 5 & 5 \\
\hline 5 & 51 & 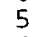 & 5 & 5 & 5 \\
\hline & 5 & 6 & & 5 & \\
\hline
\end{tabular}

END ARRAY

READ PLOT

PLT $=$ NO PIC $=$ MIX NCH $=\prime 123456789^{*}$.

TTL $=$ * "X-Y SLICE" *

$X U L=-200.0 \quad$ YUL $=200.0 \quad Z U L=0.0$

$X L R=200.0 \quad Y L R=-200.0 \quad Z L R=0.0$

$\mathrm{UAX}=1.0 \quad \mathrm{VDN}=-1.0 \quad \mathrm{NAX}=130 \quad \mathrm{END}$

TTL $=*$ "X-Z SLICE" *

$X U L=-200.0 \quad$ YUL $=0.0 \quad$ ZUL $=200.0$

$X L R=200.0 \quad Y L R=0.0 \quad \mathrm{ZLR}=-200.0$

END PLOT

$J A X=1.0 \quad W D N=-1.0 \quad$ NAX $=130 \quad$ END

END DATA

END KENO 
Listing 61. Table 14 Case 7, KBNo-v.a Input.

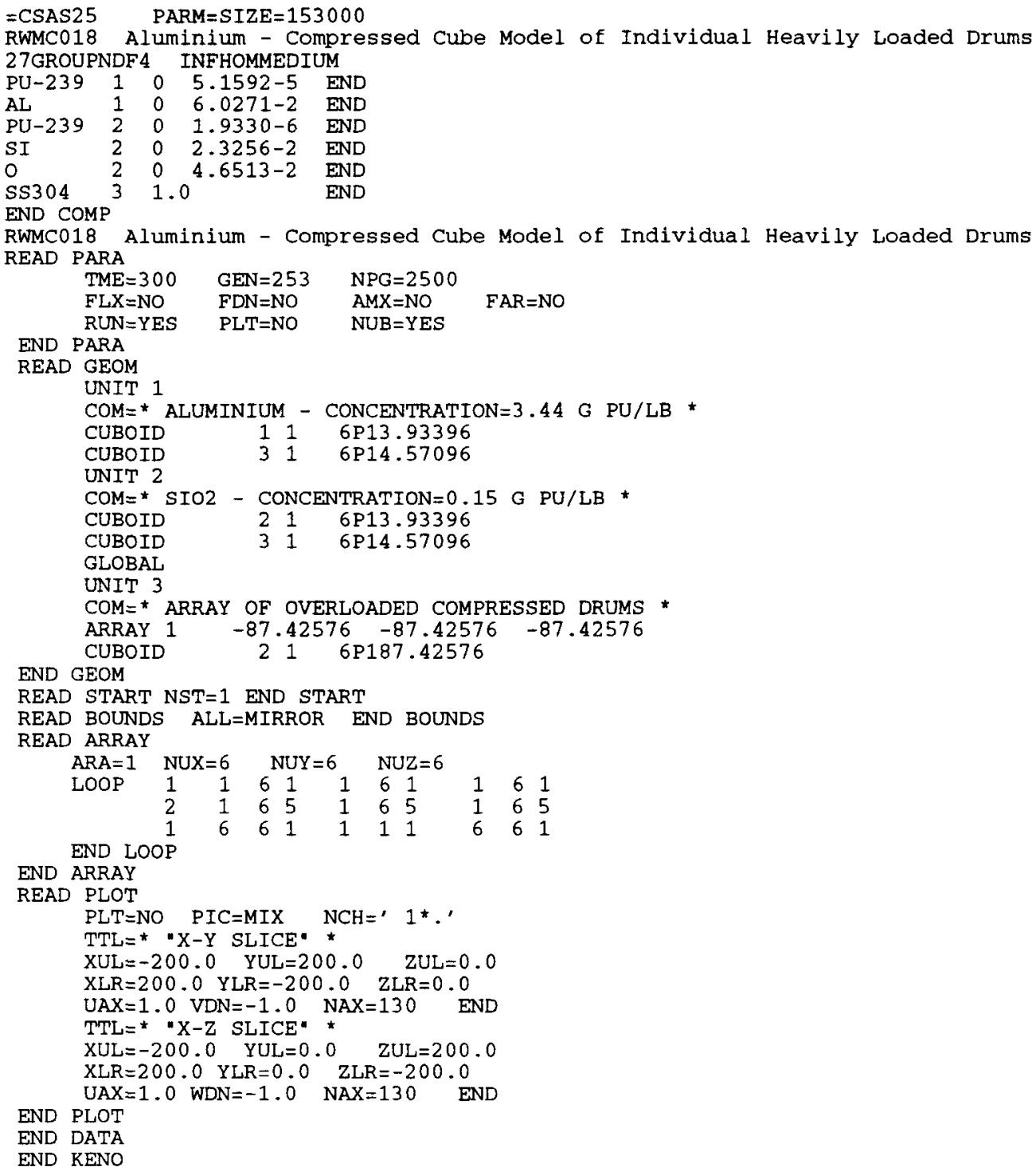


APPENDIX C:

TRANSURANIC WASTE CONTENT CODES DESCRIPTIONS 


\section{Transuranic Waste content Code Description}

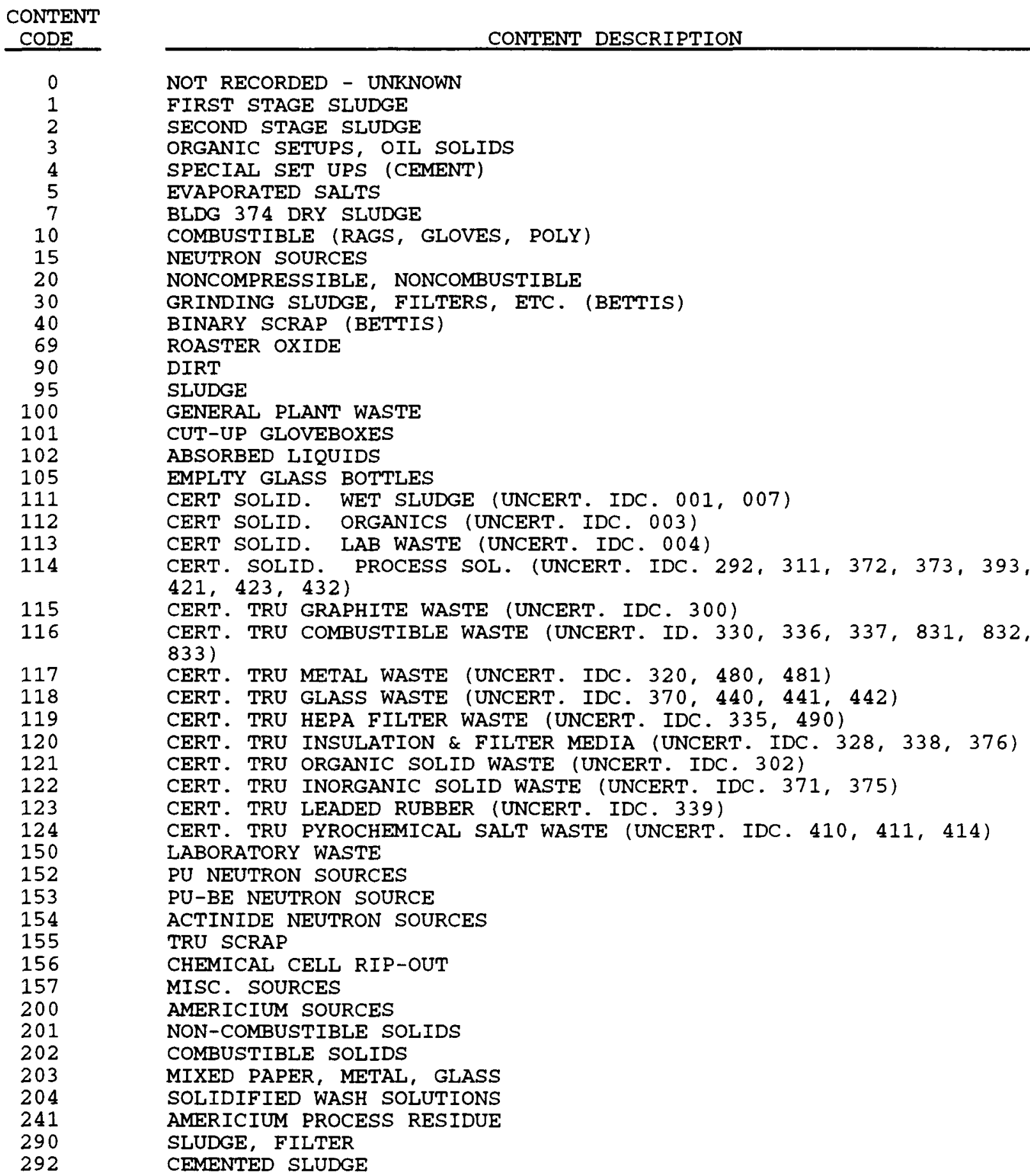




\begin{tabular}{|c|c|}
\hline 295 & SEWAGE SLUDGE \\
\hline 299 & MISCELLANEOUS SLUDGES \\
\hline 300 & GRAPHITE MOLDS \\
\hline 301 & GRAPHITE CORES \\
\hline 302 & BENELEX AND PLEXIGLASS \\
\hline 303 & SCARFED GRAPHITE CHUNKS \\
\hline 310 & GRAPHITE SCAFFINGS \\
\hline 311 & GRAPHITE HEELS \\
\hline 312 & GRAPHITE, COARSE \\
\hline 320 & TANTALUM \\
\hline 321 & LEAD \\
\hline 328 & FILTERS， FULFLO INCINERATOR \\
\hline 330 & PAPER AND RAGS - DRY \\
\hline 331 & FILTERS， FULFLO \\
\hline 332 & SLUDGE, OILY \\
\hline 333 & METAL, CALCIUM \\
\hline 334 & BLANKETS, FIRE \\
\hline 335 & FILTERS, ABSOLUTE $8 \times 8$ \\
\hline 336 & PAPER AND RAGS - MOIST \\
\hline 337 & PLASTICS, TEFLON, WASH, PVC \\
\hline 338 & INSULATION AND CWS FILTER MEDIA \\
\hline 339 & LEADED RUBBER GLOVES AND APRONS \\
\hline 360 & INSULATION \\
\hline 361 & INSULATION HEEL \\
\hline 368 & MG OXIDE CERAMIC CRUCIBLES - NOT LECO \\
\hline 370 & CRUCIBLE， LECO \\
\hline 371 & BRICK, FIRE \\
\hline 372 & GRIT \\
\hline 373 & FIRE BRICK, LECO HEELS \\
\hline 374 & BLACKTOP CONCRETE DIRT AND SAND \\
\hline 375 & OIL DRI RESIDUES FROM INCIN'TR \\
\hline 376 & CEMENT INSULATION AND FILTER MEDIA \\
\hline 377 & FIRE BRICK, COARSE \\
\hline 378 & FIRE BRICK, PULVERIZED OR FINES \\
\hline 379 & FIREBRICK， SCARFED (SCARFED FIREBRICK) \\
\hline 390 & SLAG \\
\hline 391 & CRUCIBLE AND SAND \\
\hline 392 & SAND, SLAG AND CRUCIBLES \\
\hline 393 & SAND, SLAG AND CRUCIBLE HEELS \\
\hline 409 & MOLTEN SALTS-30\% UNPULVERIZED \\
\hline 410 & MOLTEN SALTS-30\% PULVERIZED \\
\hline 411 & ELECTROREFINING SALT \\
\hline 412 & GIBSON SALTS \\
\hline 413 & IMPURE SALT - CELL CLEANOUT \\
\hline 414 & DIRECT OXIDE REDUCTION SALT \\
\hline 416 & ZINC MANGANESE ALLOY METAL \\
\hline 420 & ASH, INCINERATOR (VIRGIN) \\
\hline 421 & HEELS, ASH $(>2 \&$ G/G) \\
\hline 422 & SOOT \\
\hline 423 & RESIN, AND SOOT CALCINATED \\
\hline 425 & FLUID BED ASH \\
\hline 429 & SPENT SALT (SCRUB ALLOY SPENT SALT) \\
\hline 430 & RESIN, ION COLUMN UNLEACHED \\
\hline 431 & RESIN, LEACHED \\
\hline 432 & RESIN, LEACHED AND CEMENTED \\
\hline 438 & INSULATION (INSULATION, INCLUDING FIRE BLANKET) \\
\hline 440 & GLASS \\
\hline 441 & RASCHIG RINGS, UNLEACHED \\
\hline 442 & RASCHIG RINGS, LEACHED \\
\hline 454 & DOR SALTS (DIRECT OXIDE SALT - OXIDIZED CA) \\
\hline & WASHABLES， RUBBER， PLASTICS \\
\hline C & GLOVES, DRYBOX \\
\hline
\end{tabular}




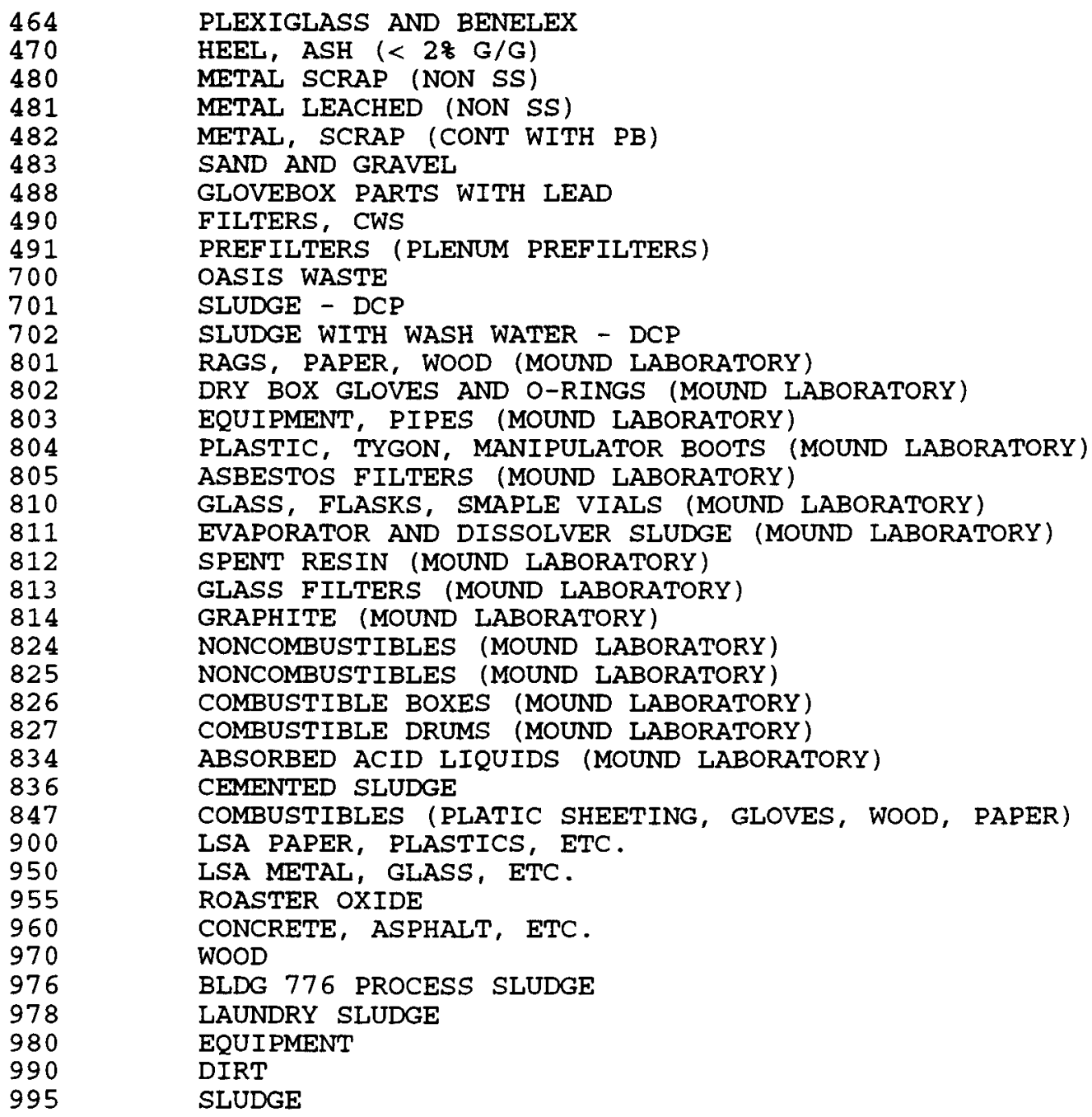


130 
APPENDIX D:

SUMMARY OF DATABASE INFORMATION BY MATRIX GROUPS 
RWMCSR $3 F$

RUN DATE: 03/08/93

PAGE NO.:

CONCENTRATION DISTRIBUTION

(GRAMS PER POUNDS)

CONTENT: ALL

CONTENT CODES: ALL

\begin{tabular}{ll}
\multicolumn{1}{c}{ CONCENTRATION } \\
RANGE \\
\hdashline 0.0 & TO 0.0 \\
0.0 & TO 0.0001 \\
0.0001 & TO 0.0002 \\
0.0002 & TO 0.0003 \\
0.0003 & TO 0.0004 \\
0.0004 & TO 0.0005 \\
0.0005 & TO 0.0006 \\
0.0006 & TO 0.0007 \\
0.0007 & TO 0.0008 \\
0.0008 & TO 0.0009 \\
0.0009 & TO 0.001 \\
0.001 & TO 0.002 \\
0.002 & TO 0.003 \\
0.003 & TO 0.004 \\
0.004 & TO 0.005 \\
0.005 & TO 0.006 \\
0.006 & TO 0.007 \\
0.007 & TO 0.008 \\
0.008 & TO 0.009 \\
0.009 & TO 0.01 \\
0.01 & TO 0.02 \\
0.02 & TO 0.03 \\
0.03 & TO 0.04 \\
0.04 & TO 0.05 \\
0.05 & TO 0.06 \\
0.06 & TO 0.07 \\
0.07 & TO 0.08 \\
0.08 & TO 0.09 \\
0.09 & TO 0.1 \\
0.1 & TO 0.2 \\
0.2 & TO 0.3 \\
0.3 & TO 0.4 \\
0.4 & TO 0.5 \\
0.5 & TO 0.6 \\
0.6 & TO 0.7 \\
0.7 & TO 0.8 \\
0.8 & TO 0.9 \\
0.9 & TO 1 \\
1 & TO 2 \\
2 & TO 3 \\
3 & TO 4 \\
4 & TO 5 \\
6 & TO 6 \\
& TO 7 \\
0.09
\end{tabular}

WEIGHTED AVERAGE

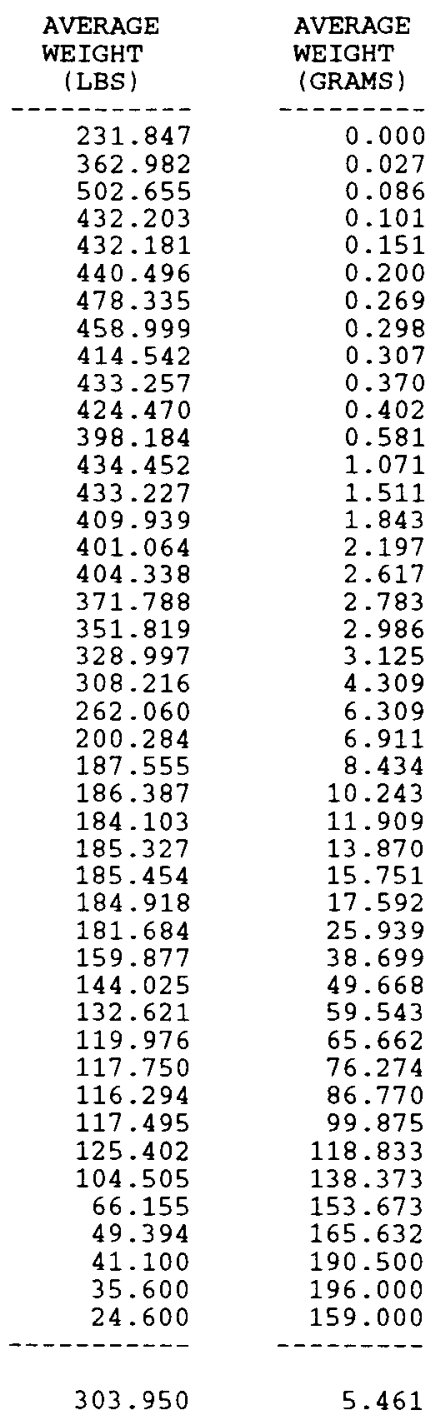

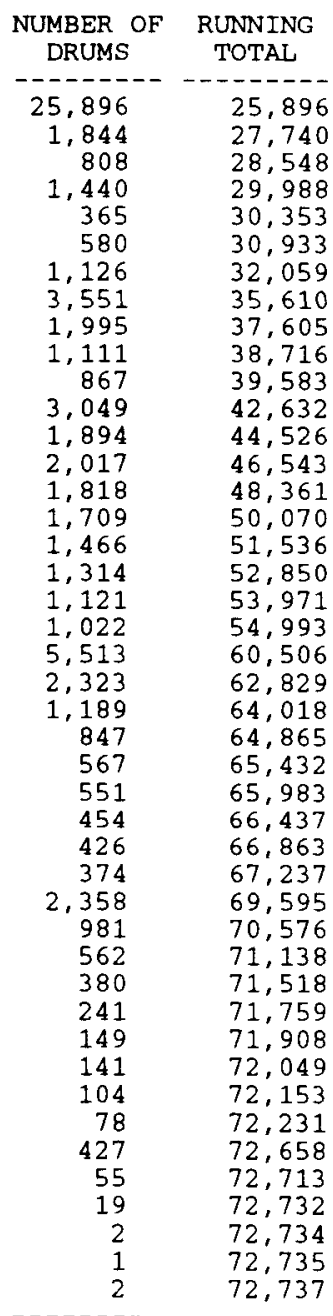

72,737

\begin{tabular}{|c|c|}
\hline $\begin{array}{l}\text { NUMBER OF } \\
\text { DRUMS }\end{array}$ & $\begin{array}{c}\text { RUNNING } \\
\text { TOTAL }\end{array}$ \\
\hline------- & ------- \\
\hline 25,896 & 25,896 \\
\hline 1,844 & 27,740 \\
\hline 808 & 28,548 \\
\hline 1,440 & 29,988 \\
\hline 365 & 30,353 \\
\hline 580 & 30,933 \\
\hline 1,126 & 32,059 \\
\hline 3,551 & 35,610 \\
\hline 1,995 & 37,605 \\
\hline 1,111 & 38,716 \\
\hline 867 & 39,583 \\
\hline 3,049 & 42,632 \\
\hline 1,894 & 44,526 \\
\hline 2,017 & 46,543 \\
\hline 1,818 & 48,361 \\
\hline 1,709 & 50,070 \\
\hline 1,466 & 51,536 \\
\hline 1,314 & 52,850 \\
\hline 1,121 & 53,971 \\
\hline 1,022 & 54,993 \\
\hline 5,513 & 60,506 \\
\hline 2,323 & 62,829 \\
\hline 1,189 & 64,018 \\
\hline 847 & 64,865 \\
\hline 567 & 65,432 \\
\hline 551 & 65,983 \\
\hline 454 & 66,437 \\
\hline 426 & 66,863 \\
\hline 374 & 67,237 \\
\hline 2,358 & 69,595 \\
\hline 981 & 70,576 \\
\hline 562 & 71,138 \\
\hline 380 & 71,518 \\
\hline 241 & 71,759 \\
\hline 149 & 71,908 \\
\hline 141 & 72,049 \\
\hline 104 & 72,153 \\
\hline 78 & 72,231 \\
\hline 427 & 72,658 \\
\hline 55 & 72,713 \\
\hline 19 & 72,732 \\
\hline 2 & 72,734 \\
\hline 1 & 72,735 \\
\hline 2 & 72,737 \\
\hline & \\
\hline 73 & \\
\hline
\end{tabular}


CONCENTRATION DISTRIBUTION (GRAMS PER POUNDS)

CONTENT: POLYETHYLENE

CONTENT CODES: $3,112,123,153,202,332,337,339,423,430,431,432,460,463$, $700,802,804,812$

\begin{tabular}{lll}
\multicolumn{3}{c}{ CONCENTRATION } \\
\multicolumn{3}{c}{ RANGE } \\
\hdashline 0.0 & TO & 0.0 \\
0.0 & TO & 0.0001 \\
0.0001 & TO & 0.0002 \\
0.0002 & TO & 0.0003 \\
0.0003 & TO & 0.0004 \\
0.0004 & TO & 0.0005 \\
0.0005 & TO & 0.0006 \\
0.0006 & TO & 0.0007 \\
0.0007 & TO & 0.0008 \\
0.0008 & TO & 0.0009 \\
0.0009 & TO & 0.001 \\
0.001 & TO & 0.002 \\
0.002 & TO & 0.003 \\
0.003 & TO & 0.004 \\
0.004 & TO & 0.005 \\
0.005 & TO & 0.006 \\
0.006 & TO & 0.007 \\
0.007 & TO & 0.008 \\
0.008 & TO & 0.009 \\
0.009 & TO & 0.01 \\
0.01 & TO & 0.02 \\
0.02 & TO & 0.03 \\
0.03 & TO & 0.04 \\
0.04 & TO & 0.05 \\
0.05 & TO & 0.06 \\
0.06 & TO & 0.07 \\
0.07 & TO & 0.08 \\
0.08 & TO & 0.09 \\
0.09 & TO & 0.1 \\
0.1 & TO & 0.2 \\
0.2 & TO & 0.3 \\
0.3 & TO & 0.4 \\
0.4 & TO & 0.5 \\
0.5 & TO & 0.6 \\
0.6 & TO & 0.7 \\
0.7 & TO & 0.8 \\
0.8 & TO & 0.9 \\
0.9 & TO & 1 \\
1 & TO & 2 \\
2 & TO & 3 \\
& &
\end{tabular}

WEIGHTED AVERAGE

\begin{tabular}{l} 
AVERAGE \\
WEIGHT \\
(LBS) \\
\hline.---- \\
334.119 \\
336.893 \\
535.605 \\
428.618 \\
459.543 \\
447.949 \\
485.132 \\
456.464 \\
432.768 \\
450.702 \\
447.622 \\
346.439 \\
464.365 \\
483.707 \\
445.059 \\
422.918 \\
385.012 \\
381.049 \\
353.777 \\
296.681 \\
237.964 \\
171.132 \\
194.443 \\
223.381 \\
229.989 \\
243.705 \\
264.593 \\
253.954 \\
266.544 \\
242.359 \\
210.686 \\
193.490 \\
175.102 \\
160.736 \\
141.516 \\
94.676 \\
160.293 \\
147.694 \\
114.700 \\
41.788 \\
------- \\
\\
--149 \\
\hline
\end{tabular}

347.749

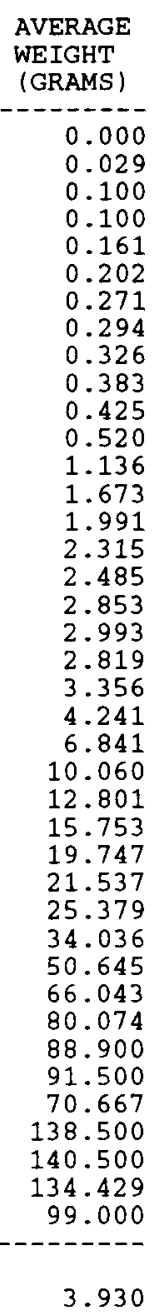

\begin{tabular}{|c|c|}
\hline $\begin{array}{l}\text { NUMBER OF } \\
\text { DRUMS }\end{array}$ & $\begin{array}{c}\text { RUNNING } \\
\text { TOTAL }\end{array}$ \\
\hline $0---1-$ & $--\ldots$ \\
\hline 4,970 & 4,970 \\
\hline 124 & 5,094 \\
\hline 161 & 5,255 \\
\hline 571 & 5,826 \\
\hline 61 & 5,887 \\
\hline 117 & 6,004 \\
\hline 160 & 6,164 \\
\hline 193 & 6,357 \\
\hline 169 & 6,526 \\
\hline 144 & 6,670 \\
\hline 105 & 6,775 \\
\hline 919 & 7,694 \\
\hline 475 & 8,169 \\
\hline 324 & 8,493 \\
\hline 215 & 8,708 \\
\hline 186 & 8.894 \\
\hline 156 & 9,050 \\
\hline 140 & 9,190 \\
\hline 97 & 9,287 \\
\hline 87 & 9,374 \\
\hline 462 & 9,836 \\
\hline 228 & 10,064 \\
\hline 166 & 10.230 \\
\hline 132 & 10,362 \\
\hline 94 & 10,456 \\
\hline 89 & 10,545 \\
\hline 60 & 10,605 \\
\hline 72 & 10,677 \\
\hline 62 & 10,739 \\
\hline 421 & 11,160 \\
\hline 108 & 11,268 \\
\hline 46 & 11,314 \\
\hline 27 & 11,341 \\
\hline 10 & 11,351 \\
\hline 8 & 11,359 \\
\hline 3 & 11362 \\
\hline 2 & 11,364 \\
\hline 4 & 11,368 \\
\hline 7 & 11,375 \\
\hline 1 & 11,376 \\
\hline & --- \\
\hline 1 & \\
\hline
\end{tabular}


CONCENTRATION DISTRIBUTION

(GRAMS PER POUNDS)

CONTENT: GRAPHITE

CONTENT CODES: $115,300,301,303,310,311,312,814$

\begin{tabular}{lll}
\multicolumn{3}{c}{ CONCENTRATION } \\
\multicolumn{3}{c}{ RANGE } \\
\hdashline 0.0 & TO & 0.0 \\
0.0 & TO & 0.0001 \\
0.0001 & TO & 0.003 \\
0.003 & TO & 0.004 \\
0.004 & TO & 0.005 \\
0.005 & TO & 0.006 \\
0.006 & TO & 0.007 \\
0.007 & TO & 0.008 \\
0.008 & TO & 0.009 \\
0.009 & TO & 0.01 \\
0.01 & TO & 0.02 \\
0.02 & TO & 0.03 \\
0.03 & TO & 0.04 \\
0.04 & TO & 0.05 \\
0.05 & TO & 0.06 \\
0.06 & TO & 0.07 \\
0.07 & TO & 0.08 \\
0.08 & TO & 0.09 \\
0.09 & TO & 0.1 \\
0.1 & TO & 0.2 \\
0.2 & TO & 0.3 \\
0.3 & TO & 0.4 \\
0.4 & TO & 0.5 \\
0.5 & TO & 0.6 \\
0.6 & TO & 0.7 \\
0.8 & TO & 0.9 \\
0.9 & TO & 1 \\
1 & TO & 2 \\
& &
\end{tabular}

WEIGHTED AVERAGE

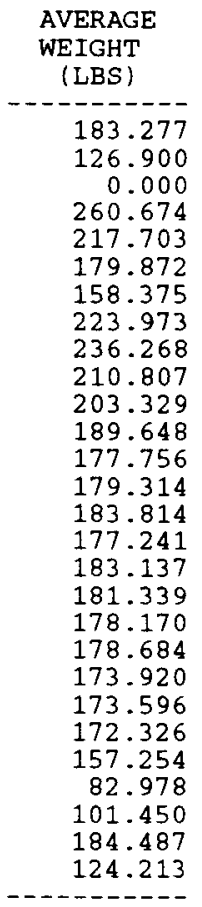

182.869

\begin{tabular}{c} 
AVERAGE \\
WEIGHT \\
(GRAMS) \\
\hline 0.000 \\
0.011 \\
0.000 \\
1.000 \\
1.000 \\
1.000 \\
1.000 \\
1.667 \\
2.000 \\
2.000 \\
3.000 \\
4.762 \\
6.175 \\
8.137 \\
10.052 \\
11.424 \\
13.691 \\
15.383 \\
16.957 \\
25.210 \\
41.577 \\
58.783 \\
75.586 \\
84.167 \\
53.750 \\
86.000 \\
182.000 \\
157.500 \\
$-9-1---$
\end{tabular}

16.583

\begin{tabular}{c} 
AVERAGE \\
CONCENTRATION \\
\hline 0.000 \\
0.000 \\
0.000 \\
0.004 \\
0.005 \\
0.006 \\
0.006 \\
0.007 \\
0.008 \\
0.009 \\
0.015 \\
0.025 \\
0.035 \\
0.045 \\
0.055 \\
0.065 \\
0.075 \\
0.085 \\
0.095 \\
0.141 \\
0.239 \\
0.339 \\
0.440 \\
0.538 \\
0.643 \\
0.848 \\
0.987 \\
1.294 \\
\hline.---1
\end{tabular}

0.095

\begin{tabular}{rr}
$\begin{array}{c}\text { NUMBER } \\
\text { DRUMS }\end{array}$ & \multicolumn{1}{r}{ RUNNING } \\
TOTAL
\end{tabular}

2,365 
CONCENTRATION DISTRIBUTION

(GRAMS PER POUNDS)

CONTENT: GLASS, SLAG

CONTENT CODES: $7,30,40,69,90,100,102,105,114,118,150,241,368,370,372$, $390,391,392,393,420,421,422,425,440,441,442,470,483,810$, $813,834,955,990$

\begin{tabular}{lll}
\multicolumn{3}{c}{ CONCENTRATION } \\
RANGE \\
$---1----$ \\
0.0 & TO & 0.0 \\
0.0 & TO & 0.0001 \\
0.0001 & TO & 0.0002 \\
0.0002 & TO & 0.0003 \\
0.0003 & TO & 0.0004 \\
0.0004 & TO & 0.0005 \\
0.0005 & TO & 0.0006 \\
0.0006 & TO & 0.0007 \\
0.0007 & TO & 0.0008 \\
0.0008 & TO & 0.0009 \\
0.0009 & TO & 0.001 \\
0.001 & TO & 0.002 \\
0.002 & TO & 0.003 \\
0.003 & TO & 0.004 \\
0.004 & TO & 0.005 \\
0.005 & TO & 0.006 \\
0.006 & TO & 0.007 \\
0.007 & TO & 0.008 \\
0.008 & TO & 0.009 \\
0.009 & TO & 0.01 \\
0.01 & TO & 0.02 \\
0.02 & TO & 0.03 \\
0.03 & TO & 0.04 \\
0.04 & TO & 0.05 \\
0.05 & TO & 0.06 \\
0.06 & TO & 0.07 \\
0.07 & TO & 0.08 \\
0.08 & TO & 0.09 \\
0.09 & TO & 0.1 \\
0.1 & TO & 0.2 \\
0.2 & TO & 0.3 \\
0.3 & TO & 0.4 \\
0.4 & TO & 0.5 \\
0.5 & TO & 0.6 \\
0.6 & TO & 0.7 \\
0.7 & TO & 0.8 \\
0.8 & TO & 0.9 \\
0.9 & TO & 1 \\
1 & TO & 2 \\
2 & TO & 3 \\
& &
\end{tabular}

WEIGHTED AVERAGE

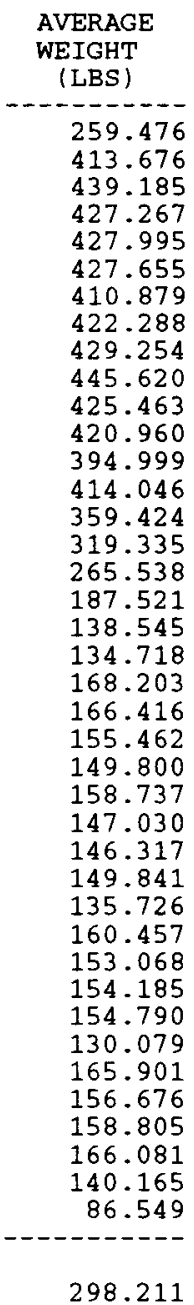

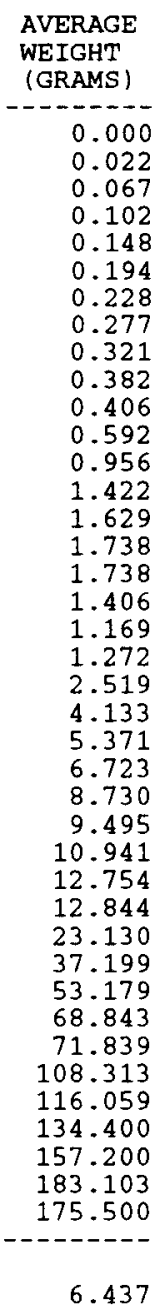

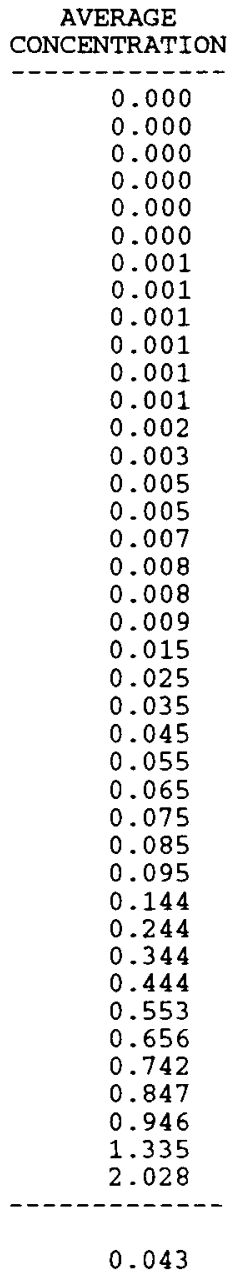


CONCENTRATION DISTRIBUTION

(GRAMS PER POUNDS)

CONTENT: CELLULOSE

CONTENT CODES: $10,116,119,120,121,153,203,302,328,330,331,334,335$, $336,338,360,361,375,376,438,464,490,491,801,805$, $826,827,847,900,970$

\begin{tabular}{lll}
\multicolumn{3}{c}{ CONCENTRATION } \\
\multicolumn{3}{c}{ RANGE } \\
\hdashline 0.0 & TO & 0.0 \\
0.0 & TO & 0.0001 \\
0.0001 & TO & 0.0004 \\
0.0004 & TO & 0.0005 \\
0.0005 & TO & 0.0006 \\
0.0006 & TO & 0.0007 \\
0.0007 & TO & 0.0008 \\
0.0008 & TO & 0.0009 \\
0.0009 & TO & 0.001 \\
0.001 & TO & 0.002 \\
0.002 & TO & 0.003 \\
0.003 & TO & 0.004 \\
0.004 & TO & 0.005 \\
0.005 & TO & 0.006 \\
0.005 & TO & 0.007 \\
0.007 & TO & 0.008 \\
0.008 & TO & 0.009 \\
0.009 & TO & 0.01 \\
0.01 & TO & 0.02 \\
0.02 & TO & 0.03 \\
0.03 & TO & 0.04 \\
0.04 & TO & 0.05 \\
0.05 & TO & 0.06 \\
0.06 & TO & 0.07 \\
0.07 & TO & 0.08 \\
0.08 & TO & 0.09 \\
0.09 & TO & 0.1 \\
0.1 & TO & 0.2 \\
0.2 & TO & 0.3 \\
0.3 & TO & 0.4 \\
0.4 & TO & 0.5 \\
0.5 & TO & 0.6 \\
0.6 & TO & 0.7 \\
0.7 & TO & 0.8 \\
0.8 & TO & 0.9 \\
0.9 & TO & 1 \\
1 & TO & 2 \\
2 & TO & 3 \\
3 & TO & 4 \\
4 & TO & 5 \\
5 & TO & 6 \\
6 & TO & 7 \\
& &
\end{tabular}

WEIGHTED AVERAGE

\begin{tabular}{|c|c|}
\hline $\begin{array}{l}\text { AVERAGE } \\
\text { WEIGHT } \\
\text { (LBS) }\end{array}$ & $\begin{array}{l}\text { AVERAGE } \\
\text { WEIGHT } \\
\text { (GRAMS) }\end{array}$ \\
\hline $\begin{array}{r}128.471 \\
87.712 \\
0.000 \\
202.449 \\
170.517 \\
160.538 \\
137.253 \\
119.624 \\
105.986 \\
167.814 \\
205.965 \\
280.632 \\
218.420 \\
179.688 \\
164.307 \\
145.390 \\
138.329 \\
127.690 \\
121.232 \\
131.072 \\
133.219 \\
132.691 \\
134.601 \\
128.445 \\
135.407 \\
131.644 \\
117.754 \\
127.577 \\
119.392 \\
109.782 \\
101.206 \\
103.287 \\
97.979 \\
100.364 \\
101.052 \\
95.538 \\
85.108 \\
65.900 \\
44.465 \\
41.100 \\
35.600 \\
29.000\end{array}$ & $\begin{array}{r}0.000 \\
0.007 \\
0.000 \\
0.100 \\
0.100 \\
0.100 \\
0.100 \\
0.100 \\
0.100 \\
0.262 \\
0.529 \\
1.000 \\
0.983 \\
0.985 \\
1.077 \\
1.094 \\
1.174 \\
1.214 \\
1.758 \\
3.226 \\
4.618 \\
5.972 \\
7.435 \\
8.341 \\
10.180 \\
11.177 \\
11.241 \\
18.759 \\
29.389 \\
38.091 \\
45.643 \\
56.625 \\
63.553 \\
74.639 \\
86.033 \\
90.108 \\
117.427 \\
152.795 \\
150.222 \\
190.500 \\
196.000 \\
195.000\end{array}$ \\
\hline & \\
\hline 126.79 & 0. \\
\hline
\end{tabular}

\begin{tabular}{c} 
AVERAGE \\
CONCENTRATION \\
\hline 0.000 \\
0.000 \\
0.000 \\
0.000 \\
0.001 \\
0.001 \\
0.001 \\
0.001 \\
0.001 \\
0.001 \\
0.003 \\
0.004 \\
0.005 \\
0.005 \\
0.007 \\
0.008 \\
0.009 \\
0.010 \\
0.014 \\
0.025 \\
0.035 \\
0.045 \\
0.055 \\
0.065 \\
0.075 \\
0.085 \\
0.095 \\
0.147 \\
0.248 \\
0.346 \\
0.451 \\
0.547 \\
0.648 \\
0.746 \\
0.851 \\
0.943 \\
1.392 \\
2.349 \\
3.381 \\
4.634 \\
5.506 \\
6.724 \\
$--.-1--$ \\
0.069 \\
--
\end{tabular}

\begin{tabular}{rr} 
NUMBER OF & RUNNING \\
DRUMS & TOTAL \\
\hdashline 11,704 & 11,704 \\
242 & 11,946 \\
0 & 11,946 \\
2 & 11,948 \\
1 & 11,949 \\
1 & 11,950 \\
3 & 11,953 \\
1 & 11,954 \\
3 & 11,957 \\
13 & 11,970 \\
7 & 11,977 \\
20 & 11,997 \\
105 & 12,102 \\
98 & 12,200 \\
39 & 12,239 \\
80 & 12,319 \\
100 & 12,419 \\
154 & 12,573 \\
840 & 13,413 \\
359 & 13,772 \\
226 & 13,998 \\
145 & 14,143 \\
93 & 14,236 \\
87 & 14,323 \\
84 & 14,407 \\
81 & 14,488 \\
63 & 14,551 \\
478 & 15,029 \\
297 & 15,326 \\
232 & 15,558 \\
174 & 15,732 \\
119 & 15,851 \\
73 & 15,924 \\
79 & 16,003 \\
60 & 16,063 \\
37 & 16,100 \\
251 & 16,351 \\
44 & 16,395 \\
9 & 16,404 \\
2 & 16,406 \\
1 & 16,407 \\
1 & 16,408 \\
------1 & \\
16,408 & \\
& \\
\hline 4 &
\end{tabular}


CONCENTRATION DISTRIBUTION

(GRAMS PER POUNDS)

CONTENT: CONCRETE

CONTENT CODES: $1,2,4,15,95,111,113,122,152,154,157,200,204,290$, $292,295,299,374,701,702,811,812,836,960,976$, $978,980,995$

\begin{tabular}{lll}
\multicolumn{3}{c}{ CONCENTRATION } \\
RANGE \\
--10.0 \\
0.0 & TO & 0.0 \\
0.0 & TO & 0.0001 \\
0.0001 & TO & 0.0002 \\
0.0002 & TO & 0.0003 \\
0.0003 & TO & 0.0004 \\
0.0004 & TO & 0.0005 \\
0.0005 & TO & 0.0006 \\
0.0006 & TO & 0.0007 \\
0.0007 & TO & 0.0008 \\
0.0008 & TO & 0.0009 \\
0.0009 & TO & 0.001 \\
0.001 & TO & 0.002 \\
0.002 & TO & 0.003 \\
0.003 & TO & 0.004 \\
0.004 & TO & 0.005 \\
0.005 & TO & 0.006 \\
0.006 & TO & 0.007 \\
0.007 & TO & 0.008 \\
0.008 & TO & 0.009 \\
0.009 & TO & 0.01 \\
0.01 & TO & 0.02 \\
0.02 & TO & 0.03 \\
0.03 & TO & 0.04 \\
0.04 & TO & 0.05 \\
0.05 & TO & 0.06 \\
0.06 & TO & 0.07 \\
0.07 & TO & 0.08 \\
0.08 & TO & 0.09 \\
0.09 & TO & 0.1 \\
0.1 & TO & 0.2 \\
0.2 & TO & 0.3 \\
0.3 & TO & 0.4 \\
0.4 & TO & 0.5 \\
0.5 & TO & 0.6 \\
0.6 & TO & 0.7 \\
0.7 & TO & 0.8 \\
0.8 & TO & 0.9 \\
0.9 & TO & 1 \\
1 & TO & 2 \\
& &
\end{tabular}

WEIGHTED AVERAGE

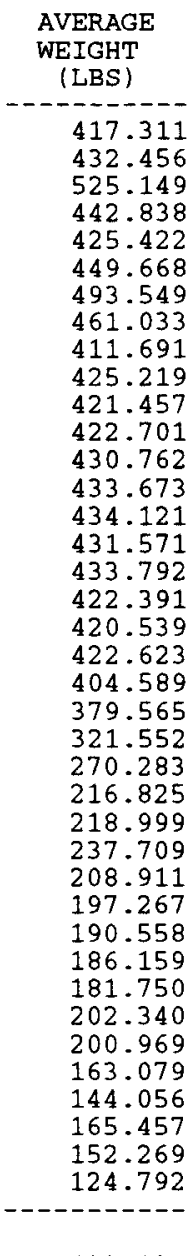

422.036

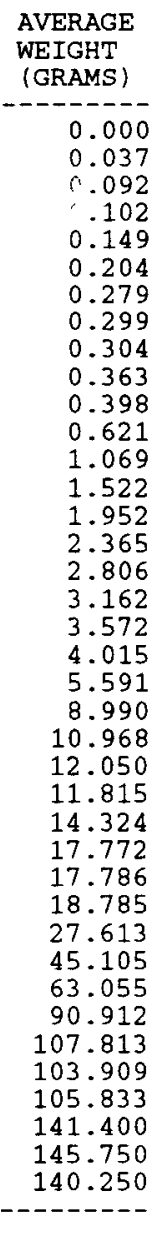

2.881

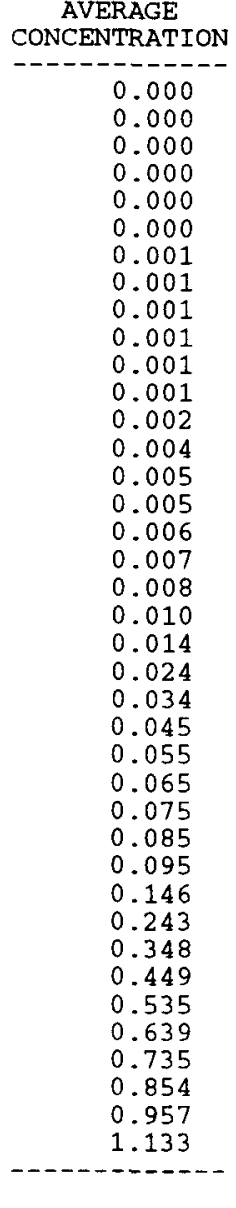

$\begin{array}{rr}\begin{array}{c}\text { NUMBER OF } \\ \text { DRUMS }\end{array} & \begin{array}{c}\text { RUNNING } \\ \text { TOTAL }\end{array} \\ ----- & ---- \\ 3,439 & 3,439 \\ 845 & 4,284 \\ 416 & 4,700 \\ 407 & 5,107 \\ 154 & 5,261 \\ 251 & 5,512 \\ 778 & 6,290 \\ 3,203 & 9,493 \\ 1,655 & 11,148 \\ 693 & 11,841 \\ 556 & 12,397 \\ 1,291 & 13,688 \\ 1,181 & 14,869 \\ 1,281 & 16,150 \\ 1,310 & 17,460 \\ 1,274 & 18,734 \\ 1,147 & 19,881 \\ 927 & 20,808 \\ 764 & 21,572 \\ 637 & 22,209 \\ 3,253 & 25,462 \\ 1,062 & 26,524 \\ 270 & 26,794 \\ 134 & 26,928 \\ 73 & 27,001 \\ 54 & 27,055 \\ 29 & 27,084 \\ 35 & 27,119 \\ 24 & 27,143 \\ 172 & 27,315 \\ 73 & 27,388 \\ 56 & 27,444 \\ 32 & 27,476 \\ 16 & 27,492 \\ 11 & 27,503 \\ 6 & 27,509 \\ 5 & 27,514 \\ 4 & 27,518 \\ 8 & 27,526 \\ ----- & ------\end{array}$

27,526 
CONCENTRATION DISTRIBUTION

(GRAMS PER POUNDS)

CONTENT: METALS

CONTENT CODES: $20,101,117,155,156,201,320,321,333,416,480,481,482,488$, $803,824,825,950$

\begin{tabular}{lll}
\multicolumn{3}{c}{ CONCENTRATION } \\
\multicolumn{3}{c}{ RANGE } \\
\hdashline 0.0 & TO & 0.0 \\
0.0 & TO & 0.0001 \\
0.0001 & TO & 0.001 \\
0.001 & TO & 0.002 \\
0.002 & TO & 0.003 \\
0.003 & TO & 0.004 \\
0.004 & TO & 0.005 \\
0.005 & TO & 0.006 \\
0.006 & TO & 0.007 \\
0.007 & TO & 0.008 \\
0.008 & TO & 0.009 \\
0.009 & TO & 0.01 \\
0.01 & TO & 0.02 \\
0.02 & TO & 0.03 \\
0.03 & TO & 0.04 \\
0.04 & TO & 0.05 \\
0.05 & TO & 0.06 \\
0.06 & TO & 0.07 \\
0.07 & TO & 0.08 \\
0.08 & TO & 0.09 \\
0.09 & TO & 0.1 \\
0.1 & TO & 0.2 \\
0.2 & TO & 0.3 \\
0.3 & TO & 0.4 \\
0.4 & TO & 0.5 \\
0.5 & TO & 0.6 \\
0.6 & TO & 0.7 \\
0.7 & TO & 0.8 \\
0.8 & TO & 0.9 \\
0.9 & TO & 1 \\
1 & TO & 2 \\
2 & TO & 3 \\
3 & TO & 4 \\
& &
\end{tabular}

WEIGHTED AVERAGE

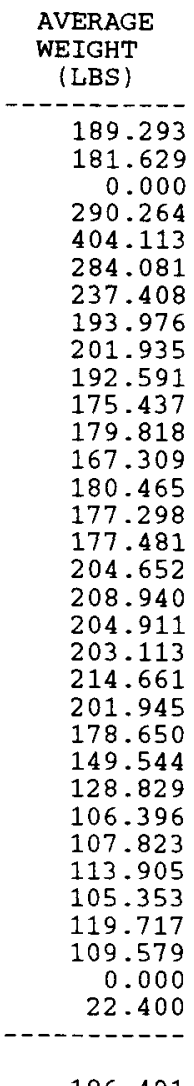

186.491

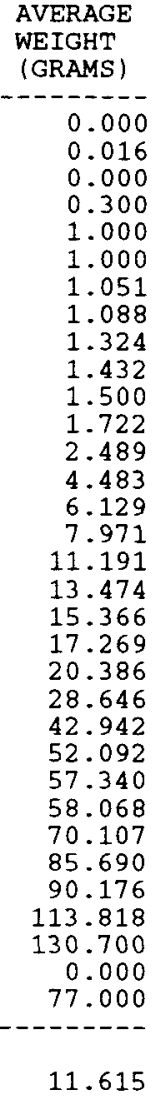

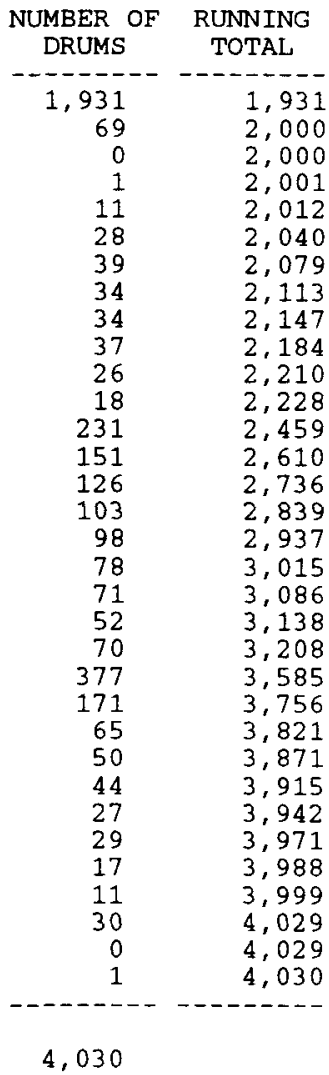


RWMCSR $3 F$

PAGE NO.:

RUN DATE: 03/08/93

CONCENTRATION DISTRIBUTION

(GRAMS PER POUNDS)

CONTENT: SALTS

CONTENT CODES: $5,124,409,410,411,412,413,414,429,454$

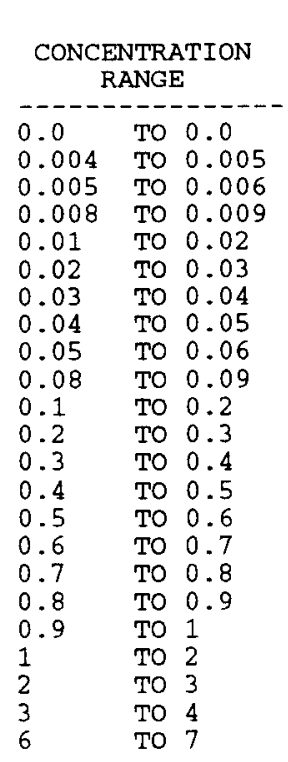

\begin{tabular}{lr}
$\begin{array}{l}\text { AVERAGE } \\
\text { WEIGHT } \\
\text { (LBS) }\end{array}$ & $\begin{array}{r}\text { AVERAGE } \\
\text { WEIGHT } \\
\text { (GRAMS) }\end{array}$ \\
\hline 348.641 & $-r$ \\
375.335 & 0.000 \\
189.975 & 1.600 \\
242.365 & 1.000 \\
257.391 & 2.000 \\
191.472 & 3.715 \\
239.372 & 5.333 \\
309.224 & 9.000 \\
313.216 & 14.000 \\
251.346 & 16.000 \\
143.324 & 21.500 \\
245.398 & 17.250 \\
175.850 & 60.250 \\
205.000 & 61.500 \\
155.918 & 100.000 \\
293.000 & 84.333 \\
209.400 & 191.000 \\
190.333 & 158.400 \\
178.600 & 169.833 \\
129.848 & 160.222 \\
65.507 & 159.875 \\
57.322 & 190.889 \\
20.200 & 123.000 \\
--185 & \\
185.913 & 95.501
\end{tabular}

\begin{tabular}{cr}
$\begin{array}{c}\text { NUMBER OF } \\
\text { DRUMS }\end{array}$ & $\begin{array}{r}\text { RUNNING } \\
\text { TOTAL }\end{array}$ \\
-4 & 4 \\
4 & 8 \\
2 & 10 \\
1 & 11 \\
8 & 19 \\
3 & 22 \\
1 & 23 \\
2 & 25 \\
1 & 26 \\
2 & 28 \\
4 & 32 \\
4 & 36 \\
4 & 40 \\
1 & 41 \\
3 & 44 \\
1 & 45 \\
5 & 50 \\
6 & 56 \\
5 & 61 \\
9 & 70 \\
8 & 78 \\
9 & 87 \\
1 & \\
$-1--$ & \\
\hline 88 &
\end{tabular}




\section{CONCENTRATION DISTRIBUTION}

(GRAMS PER POUNDS)

CONTENT: BRICK

CONTENT CODES: $371,373,377,378,379$

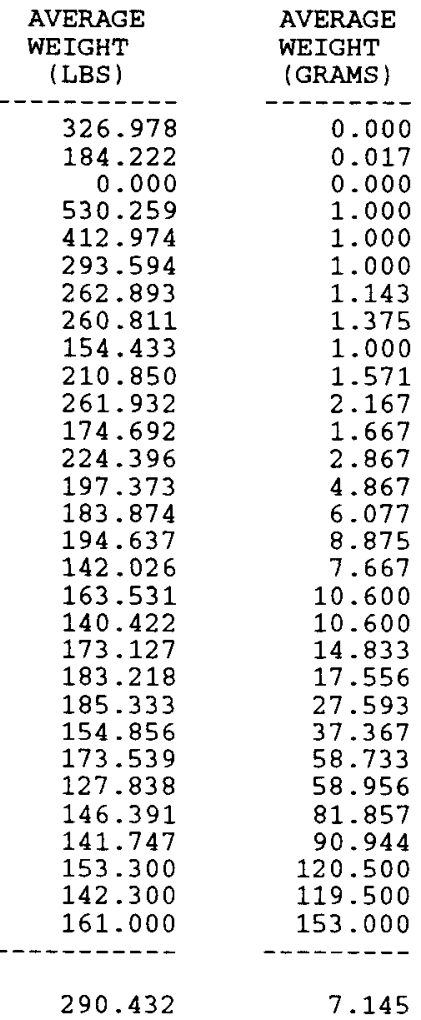

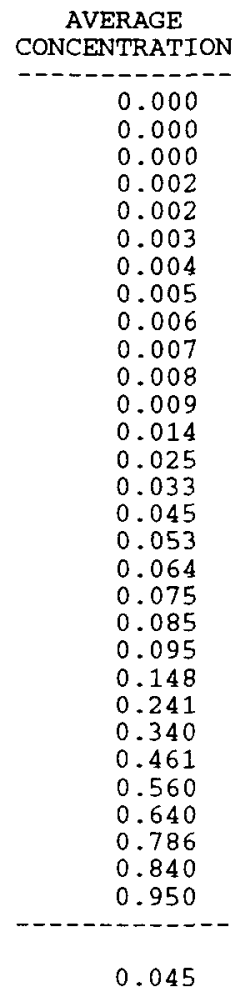

\begin{tabular}{|c|c|}
\hline $\begin{array}{l}\text { NUMBER OF } \\
\text { DRUMS }\end{array}$ & $\begin{array}{l}\text { RUNNING } \\
\text { TOTAL }\end{array}$ \\
\hline--------- & --------- \\
\hline 691 & 691 \\
\hline 9 & 700 \\
\hline 0 & 700 \\
\hline 2 & 702 \\
\hline 39 & 741 \\
\hline 20 & 761 \\
\hline 7 & 768 \\
\hline 8 & 776 \\
\hline 8 & 784 \\
\hline 7 & 791 \\
\hline 6 & 797 \\
\hline 3 & 800 \\
\hline 15 & 815 \\
\hline 15 & 830 \\
\hline 13 & 843 \\
\hline 16 & 859 \\
\hline 6 & 865 \\
\hline 10 & 875 \\
\hline 5 & 880 \\
\hline 6 & 886 \\
\hline 9 & 895 \\
\hline 54 & 949 \\
\hline 30 & 979 \\
\hline 15 & 994 \\
\hline 16 & 1,010 \\
\hline 7 & 1,017 \\
\hline 9 & 1,026 \\
\hline 2 & 1,028 \\
\hline 2 & 1,030 \\
\hline 1 & 1,031 \\
\hline-- & --------- \\
\hline 1,031 & \\
\hline
\end{tabular}


RWMCSR $3 \mathrm{H}$

RUN DATE : 03/08/93

MATRIX WEIGHT DISTRIBUTION

(POUNDS)

CONTENT: ALL

CONTENT CODES: ALL

MATRIX WEIGHT
RANGE
10 TO 25 LBS.

25 TO 50 LBS.

50 TO 75 LBS.

75 TO 100 LBS.

100 TO 125 LBS

125 TO 150 LBS.

150 TO 175 LBS.

175 TO 200 LBS.

200 TO 225 LBS.

225 TO 250 LBS.

250 TO 275 LBS.

275 TO 300 LBS.

300 TO 325 LBS.

325 TO 350 LBS.

350 TO 375 LBS.

375 TO 400 LBS.

400 TO 425 LBS.

425 TO 450 LBS.

450 TO 475 LBS.

475 TO 500 LBS.

500 TO 525 LBS.

525 TO 550 LBS.

550 TO 575 LBS.

575 TO 600 LBS.

600 TO 625 LBS.

625 TO 650 LBS.

650 TO 675 LBS.

675 TO 700 LBS.

700 TO 725 LBS.

725 TO 750 LBS.

750 TO 775 LBS.

775 TO 800 LBS.

800 TO 825 LBS.

900 TO 925 LBS.

WEIGHTED AVERAGE

\begin{tabular}{c} 
AVERAGE \\
WEIGHT \\
(LBS) \\
\hline----- \\
\hline 22.74 \\
42.79 \\
64.56 \\
88.02 \\
112.11 \\
136.68 \\
161.45 \\
185.82 \\
210.05 \\
236.34 \\
262.65 \\
287.72 \\
312.79 \\
337.45 \\
361.34 \\
385.37 \\
413.27 \\
440.44 \\
464.32 \\
488.04 \\
512.30 \\
536.66 \\
560.63 \\
584.51 \\
610.62 \\
638.94 \\
663.52 \\
687.83 \\
710.26 \\
733.38 \\
753.29 \\
784.22 \\
814.09 \\
922.20 \\
------ \\
302.53
\end{tabular}

RUNNING
TOTAL
-8
433
3,210
8,652
15,088
19,790
23,481
26,629
29,046
30,731
31,937
32,991
34,285
36,034
38,919
43,419
51,593
57,896
63,136
67,051
69,415
70,934
71,709
72,133
72,444
72,589
72,665
72,697
72,716
72,729
72,730
72,733
72,735
72,736
72,736

NUMBER OF
DRUMS
-8
425
2,777
5,442
6,436
4,702
3,691
3,148
2,417
1,685
1,206
1,054
1,294
1,749
2,885
00
.74
6,303
5,240
3,915
2,364
1,519
775
424
311
145
76
32
19
13
---7
72,736


RWMCSR $3 H$

RUN DATE : $10 / 14 / 93$

PAGE NO.:

MATRIX WEIGHT DISTRIBUTION

(POUNDS)

CONTENT: POLYETHYLENE

CONTENT CODES: $3,112,123,153,202,332,337,339,423,430,431,432,460,463$, $700,802,804,812$

MATRIX WEIGHT
RANGE

10 TO 25 LBS.

25 TO 50 LBS.

50 TO 75 LBS.

75 TO 100 LBS.

100 TO 125 LBS.

125 TO 150 LBS.

150 TO 175 LBS.

175 TO 200 LBS.

200 TO 225 LBS.

225 TO 250 LBS.

250 TO 275 LBS.

275 TO 300 LBS.

300 TO 325 LBS.

325 TO 350 LBS.

350 TO 375 LBS.

375 TO 400 LBS.

400 TO 425 LBS.

425 TO 450 LBS.

450 TO 475 LBS.

475 TO 500 LBS.

500 TO 525 LBS.

525 TO 550 LBS.

550 TO 575 LBS.

575 TO 600 LBS.

600 TO 625 LBS.

625 TO 650 LBS.

650 TO 675 LBS.

675 TO 700 LBS.

WEIGHTED AVERAGE

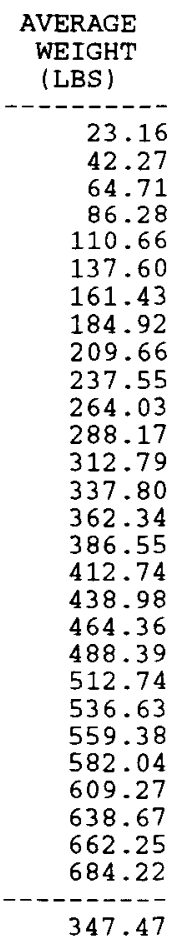

$\begin{array}{r}\text { NUMBER OF } \\ \text { DRUMS } \\ -33 \\ 26 \\ 670 \\ 647 \\ 405 \\ 314 \\ 254 \\ 186 \\ 192 \\ 247 \\ 241 \\ 237 \\ 303 \\ 429 \\ 762 \\ 997 \\ 1,258 \\ 1,021 \\ 988 \\ 848 \\ 620 \\ 427 \\ 186 \\ 66 \\ 35 \\ 10 \\ 2 \\ 2 \\ -11 \\ \hline-376\end{array}$

RUNNING

TOTAL

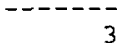

699

1,346

1,751

2,065

2,319

2,505

2,697

2,944

3,185

3,422

3,725

4,154

4,916

5,913

7,171

8,192

9,180

10,028

10,648

11,075

11,261

11,327

11,362

11,372

11,374

11,376

11,376 
RWMCSR $3 \mathrm{H}$

RUN DATE: 10/14/93

MATRIX WEIGHT DISTRIBUTION

(POUNDS)

CONTENT: GRAPHITE

CONTENT CODES: $115,300,301,303,310,311,312,814$

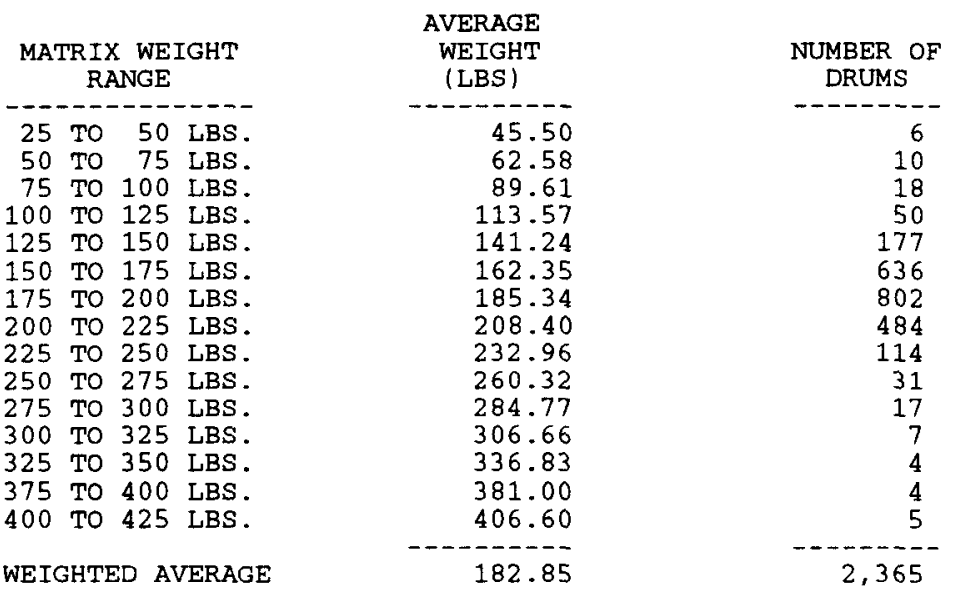

RUNNING

TOTAL

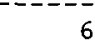

16

34

261

897

1,699

2,183

2,297

2,328

2,345

2,352

2,356

2,360

2,365 
RWMCSR $3 \mathrm{H}$

RUN DATE: $10 / 14 / 93$

PAGE NO. :

MATRIX WEIGHT DISTRIBUTION

(POUNDS)

CONTENT: GLASS, SLAG

CONTENT CODES: $7,30,40,69,90,100,102,105,114,118,150,241,368,370,372$, $390,391,392,393,420,421,422,425,440,441,442,470,483,810$, $813,834,955,990$

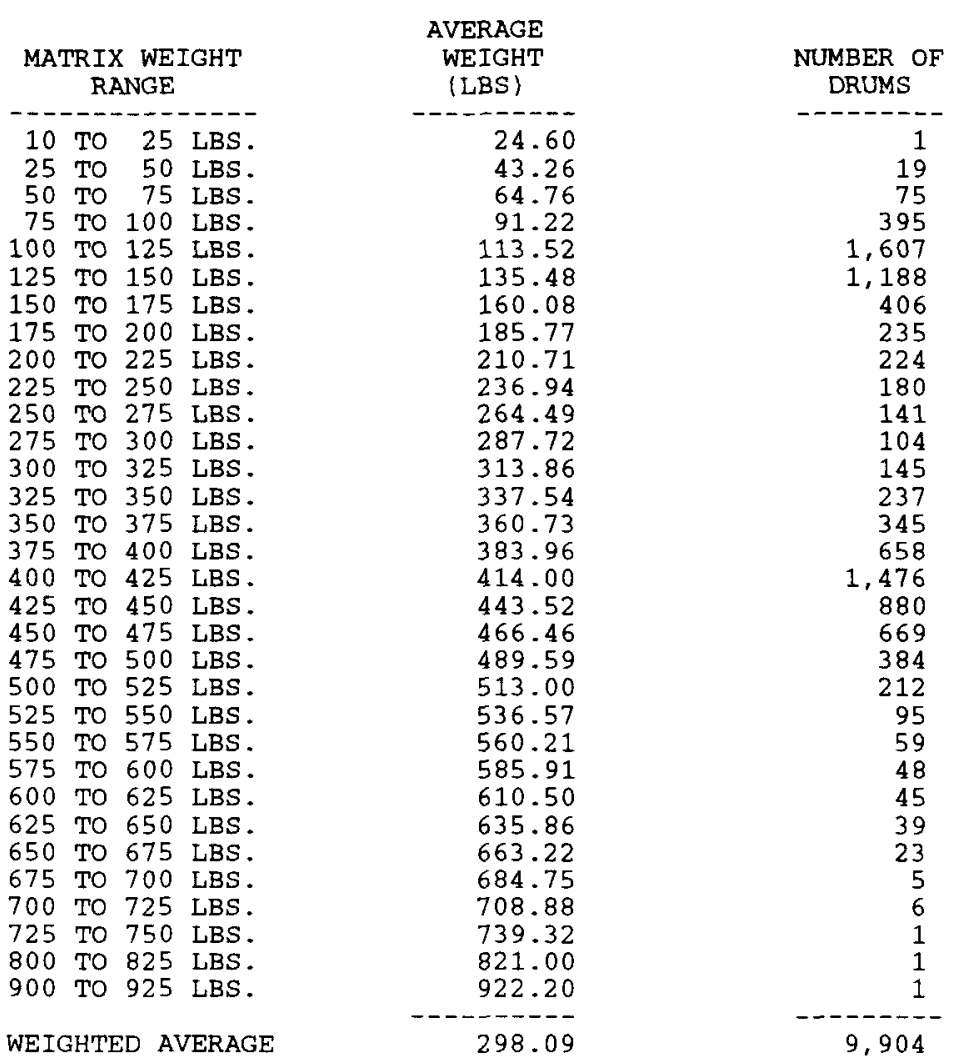

RUNNING
TOTAL
21
20
95
490
2,097
3,285
3,691
3,926
4,150
4,330
4,471
4,575
4,720
4,957
5,302
5,960
7,436
8,316
8,985
9,369
9,581
9,676
9,735
9,783
9,828
9,867
9,890
9,895
9,901
9,902
9,903
9,904

WEIGHTED AVERAGE 
RWMCSR $3 \mathrm{H}$

RUN DATE : $10 / 14 / 93$

MATRIX WEIGHT DISTRIBUTION (POUNDS)

CONTENT: CELLULOSE

CONTENT CODES: $10,116,119,120,121,153,203,302,309,328,330,331,334,335$, $336,338,360,361,375,376,438,464,490,491,801,805$, $826,827,847,900,970$

MATRIX WEIGHT RANGE

10 TO 25 LBS.

25 TO 50 LBS.

50 TO 75 LBS.

75 TO 100 LBS.

100 TO 125 LBS

125 TO 150 LBS.

150 TO 175 LBS

175 TO 200 LBS.

200 TO 225 LBS.

225 TO 250 LBS.

250 TO 275 LBS.

275 TO 300 LBS.

300 TO 325 LBS

325 TO 350 LBS.

350 TO 375 LBS.

375 TO 400 LBS.

400 TO 425 LBS.

425 TO 450 LBS.

450 TO 475 LBS

500 TO 525 LBS

525 TO 550 LBS.

650 TO 675 LBS.

WEIGHTED AVERAGE

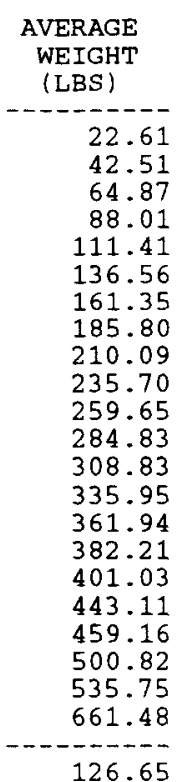

RUNNING

TOTAL

2

1,935

5,803

9,541

11,858

13,537

14,732

15,540

16,002

16,219

16,304

16,349

16,368

16,385

16,392

16,394

16,400

16,404

16,405

16,406

16,407

16,407 
RWMCSR $3 H$

RUN DATE : $10 / 14 / 93$

PAGE NO.:

1

MATRIX WEIGHT DISTRIBUTION

(POUNDS)

CONTENT: CONCRETE

CONTENT CODES: $1,2,4,15,95,111,113,122,152,154,157,200,204,290$, $292,295,299,374,701,702,811,812,836,863,960,976$, $978,980,995$

MATRIX WEIGHT RANGE

- RANGE

25 TO 50 LBS.

50 TO 75 LABS.

75 TO 100 LBS

100 TO 125 LBS

125 TO 150 LBS.

150 TO 175 LBS

175 TO 200 LBS.

200 TO 225 LBS.

225 TO 250 LBS.

250 TO 275 LBS.

275 TO 300 LBS.

300 TO 325 LBS.

325 TO 350 LBS.

350 TO 375 LBS

375 TO 400 LBS.

400 TO 425 LBS.

425 TO 450 LBS

450 TO 475 LBS.

475 TO 500 LBS

500 TO 525 LBS.

525 TO 550 LBS.

550 TO 575 LBS.

575 TO 600 LBS.

600 TO 625 LBS.

625 TO 650 LBS.

650 TO 675 LBS.

675 TO 700 LBS.

700 TO 725 LBS.

725 TO 750 LBS.

750 TO 775 LBS.

775 TO 800 LBS.

800 TO 825 LBS.

WEIGHTED AVERAGE

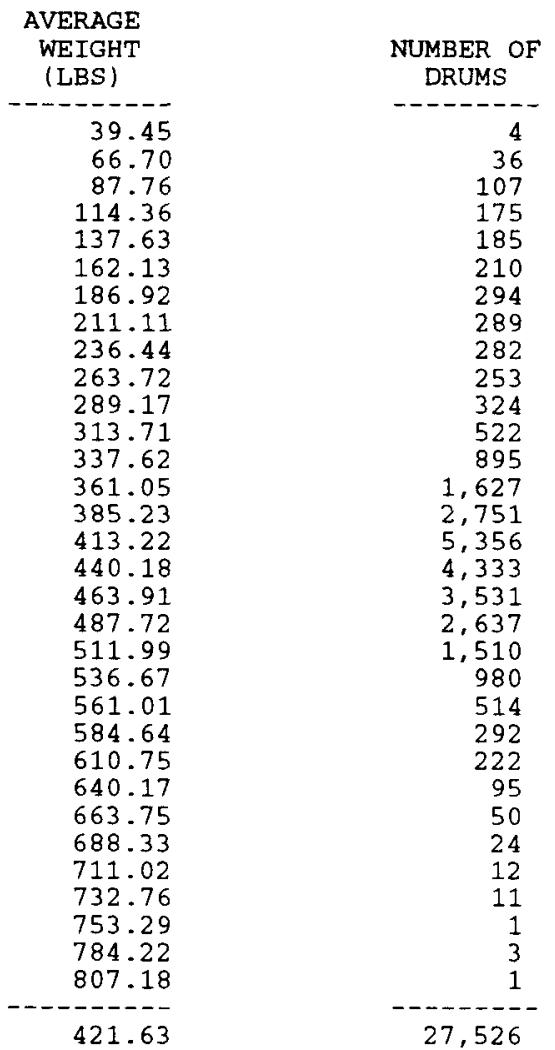

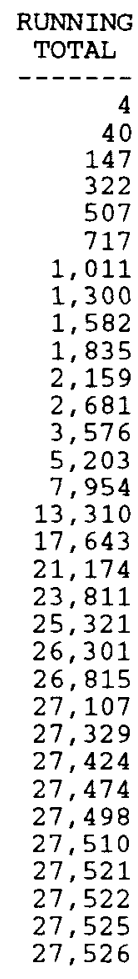

RUNNING

147

717

1,300

1,582

2,159

2,681

5,203

17,643

3,811

5,321

26,815

27,107

7,329

27,474

7,498

7,510

27,522

27,526 
RWMCSR3H

RUN DATE: $10 / 14 / 93$

MATRIX WEIGHT DISTRIBUTION (POUNDS)

CONTENT: METALS

CONTENT CODES: $20,101,117,155,156,201,320,321,333,416,480,481,482,488$, $803,824,825,950$

MATRIX WEIGHT RANGE

10 TO 25 LBS.

25 TO 50 LBS

50 TO 75 LBS

75 TO 100 LBS

100 TO 125 LBS.

125 TO 150 LBS.

150 TO 175 LBS.

175 TO 200 LBS.

200 TO 225 LBS.

225 TO 250 LBS.

250 TO 275 LBS

275 TO 300 LBS

300 TO 325 LBS.

325 TO 350 LBS.

350 TO 375 LBS.

375 TO 400 LBS.

400 TO 425 LBS

425 TO 450 LBS.

450 TO 475 LBS.

475 TO 500 LBS.

500 TO 525 LBS.

525 TO 550 LBS.

550 TO 575 LBS.

575 TO 600 LBS.

600 TO 625 LBS.

625 TO 650 LBS.

675 TO 700 LBS.

725 TO 750 LBS.

WEIGHTED AVERAGE

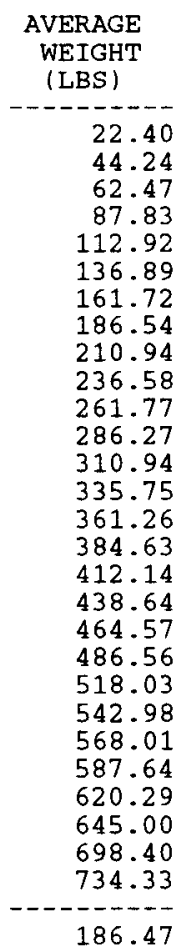

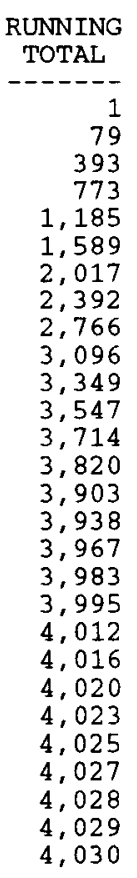


RWMCSR3H

RUN DATE: 03/08/93

PAGE NO.:

MATRIX WEIGHT DISTRIBUTION

(POUNDS)

CONTENT: SALTS

CONTENT CODES: $5,124,409,410,411,412,413,414,429,454$
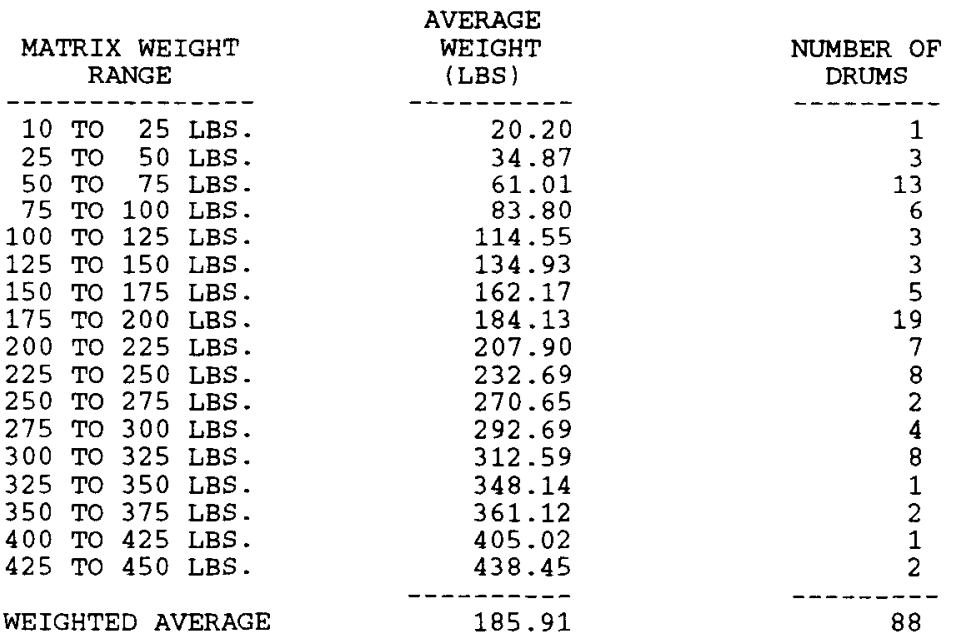

RUNNING

TOTAL

20.20

4.87

(1)

232.69

270.65

292.69

312.59

438.45

WEIGHTED AVERAGE

185.91

88 
CONCENTRATION DISTRIBUTION (GRAMS PER POUNDS)

CONTENT: ALL CONTENT CODES: ALL

\begin{tabular}{lll}
\multicolumn{1}{c}{ CONCENTRATION } \\
RANGE \\
\hdashline 0.0 & TO 0.0 \\
0.0 & TO & 0.0001 \\
0.0001 & TO & 0.0002 \\
0.0002 & TO & 0.0003 \\
0.0003 & TO & 0.0004 \\
0.0004 & TO & 0.0005 \\
0.0005 & TO & 0.0006 \\
0.0006 & TO & 0.0007 \\
0.0007 & TO & 0.0008 \\
0.0008 & TO & 0.0009 \\
0.0009 & TO & 0.001 \\
0.001 & TO & 0.002 \\
0.002 & TO & 0.003 \\
0.003 & TO & 0.004 \\
0.004 & TO & 0.005 \\
0.005 & TO & 0.006 \\
0.006 & TO & 0.007 \\
0.007 & TO & 0.008 \\
0.008 & TO & 0.009 \\
0.009 & TO & 0.01 \\
0.01 & TO & 0.02 \\
0.02 & TO & 0.03 \\
0.03 & TO & 0.04 \\
0.04 & TO & 0.05 \\
0.05 & TO & 0.06 \\
0.06 & TO & 0.07 \\
0.07 & TO & 0.08 \\
0.08 & TO & 0.09 \\
0.09 & TO & 0.1 \\
0.1 & TO & 0.2 \\
0.2 & TO & 0.3 \\
0.3 & TO & 0.4 \\
&
\end{tabular}

WEIGHTED AVERAGE

\begin{tabular}{|c|c|}
\hline $\begin{array}{c}\text { AVERAGE } \\
\text { WEIGHT } \\
\text { (LBS) }\end{array}$ & $\begin{array}{l}\text { AVERAGE } \\
\text { WEIGHT } \\
\text { (GRAMS) }\end{array}$ \\
\hline $\begin{array}{l}2,570.754 \\
2,434.270 \\
2,211.846 \\
2,631.235 \\
2,589.960 \\
2,507.764 \\
1,989.785 \\
2,054.403 \\
2,342.338 \\
2,029.640 \\
2,255.317 \\
2,828.830 \\
2,590.044 \\
2,508.740 \\
2,468.500 \\
2,200.970 \\
1,927.524 \\
1,892.677 \\
1,992.644 \\
2,051.391 \\
1,878.125 \\
1,889.342 \\
1,864.724 \\
2,034.444 \\
1,923.804 \\
2,048.376 \\
2,282.483 \\
2,045.548 \\
2,221.266 \\
1,889.217 \\
1,455.586 \\
1,679.000\end{array}$ & $\begin{array}{r}0.000 \\
0.167 \\
0.277 \\
0.656 \\
0.911 \\
1.126 \\
1.100 \\
1.324 \\
1.729 \\
1.718 \\
2.140 \\
4.347 \\
6.467 \\
8.742 \\
11.087 \\
12.002 \\
12.520 \\
14.111 \\
16.818 \\
19.506 \\
27.295 \\
46.401 \\
64.535 \\
91.638 \\
105.591 \\
132.540 \\
169.459 \\
173.823 \\
212.111 \\
241.295 \\
332.200 \\
635.500\end{array}$ \\
\hline & $x--0-0$ \\
\hline .27 & \\
\hline
\end{tabular}

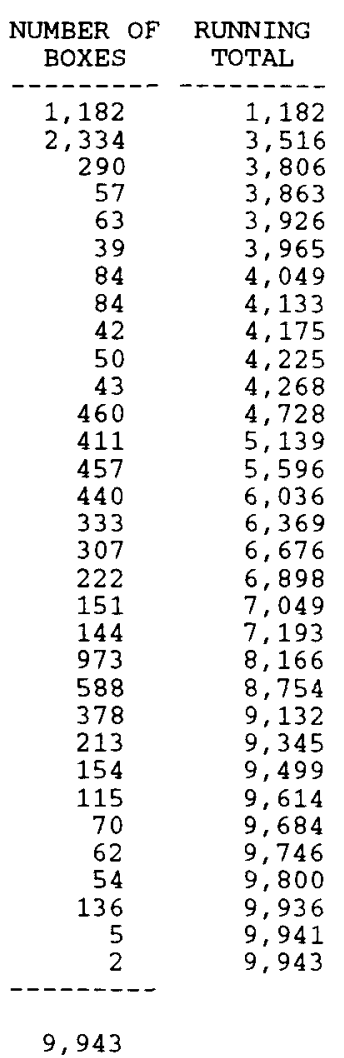

9,943

1,182
3,516
3,806
3,863
3,926
3,965
4,049
4,133
4,175
4,225
4,268
4,728
5,139
5,596
6,036
6,369
6,676
6,898
7,049
7,193
8,166
8,754
9,132
9,345
9,499
9,614
9,684
9,746
9,800
9,936
9,941
9,943
0.010 
CONCENTRATION DISTRIBUTION

(GRAMS PER POUNDS)

CONTENT: POLYETHYLENE

CONTENT CODES: $3,112,123,153,202,332,337,339,423,430,431,432,460,463$, $700,802,804,812$,

\begin{tabular}{lll}
\multicolumn{3}{c}{ CONCENTRATION } \\
RANGE \\
\hdashline 0.0 & TO 0.0001 \\
0.0003 & TO 0.0004 \\
0.0006 & TO 0.0007 \\
0.0008 & TO 0.0009 \\
0.001 & TO 0.002 \\
0.002 & TO 0.003 \\
0.005 & TO 0.006 \\
0.008 & TO 0.009 \\
0.009 & TO 0.01 \\
0.02 & TO 0.03 \\
0.03 & TO 0.04 \\
0.1 & TO 0.2
\end{tabular}

WEIGHTED AVERAGE

\begin{tabular}{|c|}
\hline $\begin{array}{l}\text { AVERAGE } \\
\text { WEIGHT } \\
\text { (LBS) }\end{array}$ \\
\hline $\begin{array}{l}2,781.016 \\
2,874.820 \\
1,569.000 \\
2,395.829 \\
2,648.629 \\
2,974.610 \\
2,854.862 \\
2,415.787 \\
1,318.099 \\
1,657.000 \\
1,701.000 \\
1,838.500\end{array}$ \\
\hline
\end{tabular}

\begin{tabular}{l} 
AVERAGE \\
WEIGHT \\
(GRAMS) \\
\hline 0.180 \\
1.000 \\
1.000 \\
2.000 \\
3.667 \\
8.000 \\
16.000 \\
21.000 \\
13.000 \\
39.000 \\
53.000 \\
296.250 \\
.-----
\end{tabular}

50.844

\begin{tabular}{c} 
AVERAGE \\
CONCENTRATION \\
\hline 0.000 \\
0.000 \\
0.001 \\
0.001 \\
0.001 \\
0.003 \\
0.006 \\
0.009 \\
0.010 \\
0.024 \\
0.031 \\
0.161 \\
0.021
\end{tabular}

\begin{tabular}{cr}
$\begin{array}{c}\text { NUMBER OF } \\
\text { BOXES }\end{array}$ & $\begin{array}{c}\text { RUNNING } \\
\text { TOTAL }\end{array}$ \\
\hline 10 & 10 \\
1 & 11 \\
1 & 12 \\
1 & 13 \\
3 & 16 \\
1 & 17 \\
1 & 18 \\
2 & 20 \\
1 & 21 \\
1 & 22 \\
1 & 23 \\
4 & 27
\end{tabular}

27 
RWMCSR 4F

RUN DATE: $10 / 14 / 93$

CONCENTRATION DISTRIBUTION

(GRAMS PER POUNDS)

CONTENT: GRAPHITE

CONTENT CODES: $115,300,301,303,310,311,312,814$

CONCENTRATION

RANGE

0.006 To 0.007

WEIGHTED AVERAGE

\begin{tabular}{l}
$\begin{array}{c}\text { AVERAGE } \\
\text { WEIGHT } \\
\text { (LBS) }\end{array}$ \\
\hline $1,876.922$ \\
$1,876.920$
\end{tabular}

$1,876.920$

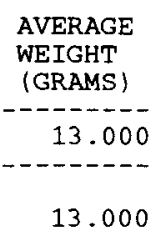

13.000

AVERAGE
CONCENTRATION
0.007
0.007

\begin{tabular}{cr}
$\begin{array}{c}\text { NUMBER OF } \\
\text { BOXES }\end{array}$ & $\begin{array}{c}\text { RUNNING } \\
\text { TOTAL }\end{array}$ \\
\hline 1 & \\
1 &
\end{tabular}

1 
RWMCSR 4F

\section{CONCENTRATION DISTRIBUTION} (GRAMS PER POUNDS)

CONTENT: GLASS, SLAG

CONTENT CODES: $7,30,40,69,90,100,102,105,114,118,150,241,368,370,372$, $390,391,392,393,420,421,422,425,440,441,442,470,483,810$, $813,834,955,990$

\begin{tabular}{lll}
\multicolumn{3}{c}{ CONCENTRATION } \\
RANGE \\
\hdashline 0.0 & TO 0.0001 \\
0.0003 & TO 0.0004 \\
0.0007 & TO & 0.0008 \\
0.001 & TO & 0.002 \\
0.002 & TO & 0.003 \\
0.003 & TO & 0.004 \\
0.004 & TO & 0.005 \\
0.005 & TO & 0.006 \\
0.006 & TO & 0.007 \\
0.007 & TO & 0.008 \\
0.008 & TO & 0.009 \\
0.01 & TO & 0.02 \\
0.02 & TO & 0.03 \\
0.03 & TO & 0.04 \\
0.04 & TO & 0.05 \\
0.05 & TO & 0.06 \\
0.06 & TO & 0.07 \\
0.07 & TO & 0.08 \\
0.08 & TO & 0.09 \\
0.09 & TO & 0.1 \\
0.1 & TO & 0.2 \\
0.2 & TO & 0.3
\end{tabular}

WEIGHTED AVERAGE

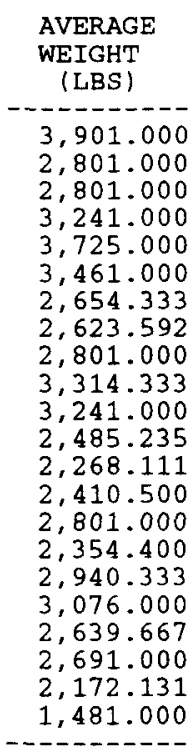

$2,636.326$

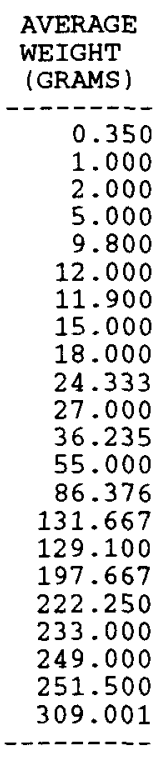

93.550

\begin{tabular}{l} 
AVERAGE \\
CONCENTRATION \\
\hline 0.000 \\
0.000 \\
0.001 \\
0.002 \\
0.003 \\
0.003 \\
0.004 \\
0.006 \\
0.006 \\
0.007 \\
0.008 \\
0.015 \\
0.024 \\
0.036 \\
0.047 \\
0.055 \\
0.067 \\
0.072 \\
0.088 \\
0.093 \\
0.116 \\
0.209 \\
$--1-\cdots$ \\
---
\end{tabular}

0.035

$\begin{array}{cr}\begin{array}{c}\text { NUMBER OF } \\ \text { BOXES }\end{array} & \begin{array}{r}\text { RUNNING } \\ \text { TOTAL }\end{array} \\ 1 & 1 \\ 1 & 2 \\ 1 & 3 \\ 2 & 5 \\ 5 & 10 \\ 1 & 11 \\ 3 & 14 \\ 2 & 16 \\ 2 & 18 \\ 3 & 21 \\ 1 & 22 \\ 17 & 39 \\ 9 & 48 \\ 12 & 60 \\ 3 & 63 \\ 10 & 73 \\ 3 & 76 \\ 4 & 80 \\ 3 & 83 \\ 2 & 85 \\ 6 & 91 \\ 1 & 92 \\ --- & \end{array}$

92 
CONCENTRATION DISTRIBUTION

(GRAMS PER POUNDS)

CONTENT: CELLULOSE

CONTENT CODES: $10,116,119,120,121,153,203,302,328,330,331,334,335$,

$336,338,360,361,375,376,438,464,490,491,801,805$,

$826,827,847,900,970$

\begin{tabular}{lll}
\multicolumn{1}{c}{$\begin{array}{c}\text { CONCENTRATION } \\
\text { RANGE }\end{array}$} \\
\hdashline 0.0 & TO & 0.0 \\
0.0 & TO & 0.0001 \\
0.0001 & TO & 0.0002 \\
0.0002 & TO & 0.0003 \\
0.0003 & TO & 0.0004 \\
0.0004 & TO & 0.0005 \\
0.0005 & TO & 0.0006 \\
0.0006 & TO & 0.0007 \\
0.0007 & TO & 0.0008 \\
0.0008 & TO & 0.0009 \\
0.0009 & TO & 0.001 \\
0.001 & TO & 0.002 \\
0.002 & TO & 0.003 \\
0.003 & TO & 0.004 \\
0.004 & TO & 0.005 \\
0.005 & TO & 0.006 \\
0.006 & TO & 0.007 \\
0.007 & TO & 0.008 \\
0.008 & TO & 0.009 \\
0.009 & TO & 0.01 \\
0.01 & TO & 0.02 \\
0.02 & TO & 0.03 \\
0.03 & TO & 0.04 \\
0.04 & TO & 0.05 \\
0.05 & TO & 0.06 \\
0.06 & TO & 0.07 \\
0.07 & TO & 0.08 \\
0.08 & TO & 0.09 \\
0.09 & TO & 0.1 \\
0.1 & TO & 0.2 \\
0.2 & TO & 0.3 \\
0.3 & TO & 0.4 \\
& &
\end{tabular}

WEIGHTED AVERAGE

\begin{tabular}{|c|c|}
\hline $\begin{array}{l}\text { AVERAGE } \\
\text { WEIGHT } \\
\text { (LBS) }\end{array}$ & $\begin{array}{l}\text { AVERAGE } \\
\text { WEIGHT } \\
\text { (GRAMS) }\end{array}$ \\
\hline $\begin{array}{l}1,520.628 \\
1,875.560 \\
1,938.670 \\
1,841.611 \\
1,980.037 \\
2,110.196 \\
1,830.283 \\
1,625.188 \\
1,627.880 \\
1,732.425 \\
1,672.268 \\
1,799.813 \\
1,723.007 \\
1,725.481 \\
1,737.281 \\
1,788.362 \\
1,725.181 \\
1,708.108 \\
1,632.069 \\
1,669.316 \\
1,625.972 \\
1,613.235 \\
1,602.322 \\
1,628.071 \\
1,517.622 \\
1,532.418 \\
1,538.529 \\
1,545.575 \\
1,662.027 \\
1,499.695 \\
1,511.977 \\
1,679.000\end{array}$ & $\begin{array}{r}0.000 \\
0.119 \\
0.247 \\
0.423 \\
0.700 \\
0.953 \\
1.014 \\
1.041 \\
1.195 \\
1.468 \\
1.594 \\
2.666 \\
4.304 \\
6.000 \\
7.821 \\
9.878 \\
11.233 \\
12.747 \\
13.788 \\
15.839 \\
23.441 \\
39.491 \\
55.803 \\
73.199 \\
83.121 \\
99.092 \\
115.094 \\
130.343 \\
157.450 \\
201.789 \\
355.333 \\
635.500\end{array}$ \\
\hline & \\
\hline 1,70 & 23.464 \\
\hline
\end{tabular}

\begin{tabular}{rr}
$\begin{array}{c}\text { NUMBER OF } \\
\text { BOXES }\end{array}$ & $\begin{array}{c}\text { RUNNING } \\
\text { TOTAL }\end{array}$ \\
\hline 191 & 191 \\
904 & 1,095 \\
126 & 1,221 \\
13 & 1,234 \\
12 & 1,246 \\
15 & 1,261 \\
63 & 1,324 \\
58 & 1,382 \\
22 & 1,404 \\
34 & 1,438 \\
18 & 1,456 \\
253 & 1,709 \\
226 & 1,935 \\
240 & 2,175 \\
153 & 2,328 \\
167 & 2,495 \\
191 & 2,686 \\
159 & 2,845 \\
108 & 2,953 \\
97 & 3,050 \\
747 & 3,797 \\
459 & 4,256 \\
286 & 4,542 \\
145 & 4,687 \\
99 & 4,786 \\
66 & 4,852 \\
32 & 4,884 \\
35 & 4,919 \\
20 & 4,939 \\
66 & 5,005 \\
3 & 5,008 \\
2 & 5,010 \\
$-1--$ &
\end{tabular}

5,010

191

1,221

, 234

, 261

, 32

1,404

.709

2.175

, 328

, 686

, 050

, 542

786

, 852

, 919

5,010
0.014 


\section{CONCENTRATION DISTRIBUTION}

(GRAMS PER POUNDS)

CONTENT: CONCRETE

CONTENT CODES: $1,2,4,15,95,111,113,122,152,154,157,200,204,290$,

$292,295,299,374,701,702,811,812,836,960,976$,

$978,980,995$

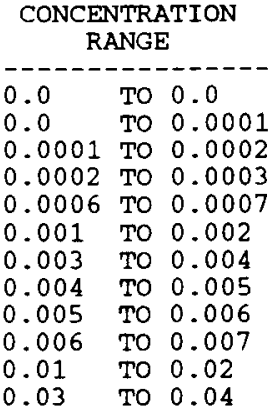

WEIGHTED AVERAGE

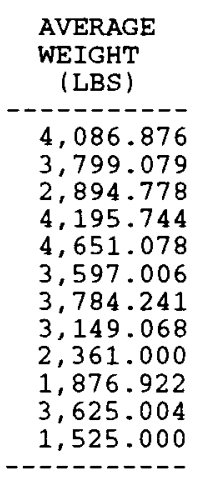

$3,948.518$

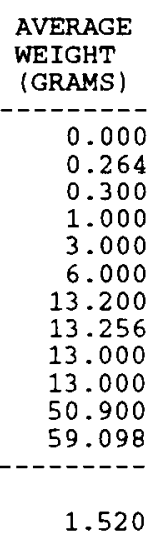

$\begin{array}{cr}\begin{array}{c}\text { NUMBER OF } \\ \text { BOXES }\end{array} & \begin{array}{r}\text { RUNNING } \\ \text { TOTAL }\end{array} \\ -164 & 164 \\ 74 & 238 \\ 1 & 239 \\ 2 & 241 \\ 1 & 242 \\ 2 & 244 \\ 5 & 249 \\ 4 & 253 \\ 1 & 254 \\ 1 & 255 \\ 3 & 258 \\ 1 & 259 \\ ---- & \\ 259 & \end{array}$


RWMCSR4F

RUN DATE : $10 / 14 / 93$

CONCENTRATION DISTRIBUTION

(GRAMS PER POUNDS)

CONTENT: METALS

CONTENT CODES: $20,101,117,155,156,201,320,321,333,416,480,481,482,488$, $803,824,825,950$

\begin{tabular}{lll}
\multicolumn{1}{c}{ CONCENTRATION } \\
RANGE \\
\hdashline 0.0 & TO 0.0 \\
0.0 & TO & 0.0001 \\
0.0001 & TO & 0.0002 \\
0.0002 & TO & 0.0003 \\
0.0003 & TO & 0.0004 \\
0.0004 & TO & 0.0005 \\
0.0005 & TO & 0.0006 \\
0.0006 & TO & 0.0007 \\
0.0007 & TO & 0.0008 \\
0.0008 & TO & 0.0009 \\
0.0009 & TO & 0.001 \\
0.001 & TO & 0.002 \\
0.002 & TO & 0.003 \\
0.003 & TO & 0.004 \\
0.004 & TO & 0.005 \\
0.005 & TO & 0.006 \\
0.006 & TO & 0.007 \\
0.007 & TO & 0.008 \\
0.008 & TO & 0.009 \\
0.009 & TO & 0.01 \\
0.01 & TO & 0.02 \\
0.02 & TO & 0.03 \\
0.03 & TO & 0.04 \\
0.04 & TO & 0.05 \\
0.05 & TO & 0.06 \\
0.06 & TO & 0.07 \\
0.07 & TO & 0.08 \\
0.08 & TO & 0.09 \\
0.09 & TO & 0.1 \\
0.1 & TO & 0.2 \\
0.2 & TO & 0.3 \\
& &
\end{tabular}

WEIGHTED AVERAGE

\begin{tabular}{|c|c|}
\hline $\begin{array}{l}\text { AVERAGE } \\
\text { WEIGHT } \\
\text { (LBS) }\end{array}$ & $\begin{array}{l}\text { AVERAGE } \\
\text { WEIGHT } \\
\text { (GRAMS) }\end{array}$ \\
\hline $\begin{array}{l}2,510.883 \\
2,734.939 \\
2,426.922 \\
2,801.153 \\
2,729.216 \\
2,756.255 \\
2,468.319 \\
3,003.724 \\
3,145.483 \\
2,678.931 \\
2,675.120 \\
4,121.563 \\
3,650.895 \\
3,362.289 \\
2,855.943 \\
2,618.284 \\
2,268.708 \\
2,319.078 \\
2,913.836 \\
2,873.026 \\
2,724.762 \\
2,927.705 \\
2,749.352 \\
2,905.588 \\
2,721.718 \\
2,730.496 \\
2,889.325 \\
2,700.421 \\
2,541.438 \\
2,292.784 \\
1,261.000\end{array}$ & $\begin{array}{r}0.000 \\
0.194 \\
0.301 \\
0.712 \\
0.959 \\
1.233 \\
1.357 \\
1.950 \\
2.332 \\
2.267 \\
2.532 \\
6.461 \\
9.095 \\
11.733 \\
12.831 \\
14.144 \\
14.683 \\
17.288 \\
24.535 \\
27.380 \\
40.320 \\
72.468 \\
93.406 \\
130.923 \\
149.800 \\
176.283 \\
214.415 \\
229.833 \\
243.969 \\
280.067 \\
286.000\end{array}$ \\
\hline & \\
\hline $2,802.169$ & 22.502 \\
\hline
\end{tabular}

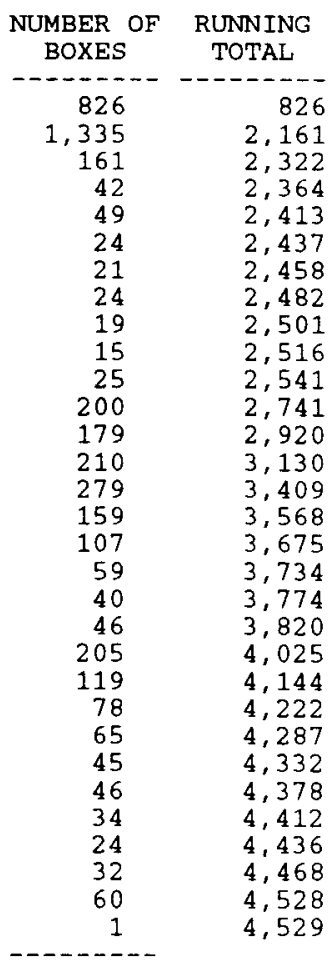

4,529

\begin{tabular}{rr}
$\begin{array}{c}\text { NUMBER OF } \\
\text { BOXES }\end{array}$ & $\begin{array}{r}\text { RUNNING } \\
\text { TOTAL }\end{array}$ \\
\hdashline 826 & 826 \\
1,335 & 2,161 \\
161 & 2,322 \\
42 & 2,364 \\
49 & 2,413 \\
24 & 2,437 \\
21 & 2,458 \\
24 & 2,482 \\
19 & 2,501 \\
15 & 2,516 \\
25 & 2,541 \\
200 & 2,741 \\
179 & 2,920 \\
210 & 3,130 \\
279 & 3,409 \\
159 & 3,568 \\
107 & 3,675 \\
59 & 3,734 \\
40 & 3,774 \\
46 & 3,820 \\
205 & 4,025 \\
119 & 4,144 \\
78 & 4,222 \\
65 & 4,287 \\
45 & 4,332 \\
46 & 4,378 \\
34 & 4,412 \\
24 & 4,436 \\
32 & 4,468 \\
60 & 4,528 \\
1 & 4,529 \\
-1 & \\
$4,-529$ &
\end{tabular}


CONCENTRATION DISTRIBUTION

(GRAMS PER POUNDS)

CONTENT: SALTS

CONTENT CODES:

$5,124,409,410,411,412,413,414,429,454$

CONCENTRATION

RANGE

0.0 TO 0.0

WEIGHTED AVERAGE

\begin{tabular}{l} 
AVERAGE \\
WEIGHT \\
(LBS) \\
\hline 3.992 .466 \\
\hline
\end{tabular}

$3,992.470$

\begin{tabular}{l} 
AVERAGE \\
WEIGHT \\
(GRAMS) \\
\hline 0.000 \\
\hline
\end{tabular}

0.000

\begin{tabular}{c} 
AVERAGE \\
CONCENTRATION \\
\hline 0.000 \\
0.000
\end{tabular}

NUMBER OF RUNNING BOXES TOTAL

1
1


CONCENTRATION DISTRIBUTION (GRAMS PER POUNDS)

CONTENT: BRICK

CONTENT CODES: $371,373,377,378,379$

\begin{tabular}{|c|c|c|}
\hline$\stackrel{\mathrm{NCE}}{\mathrm{R}}$ & $\begin{array}{l}\text { NTRA } \\
\text { ANGE }\end{array}$ & ION \\
\hline & то & 0.0001 \\
\hline & TO & 0.0002 \\
\hline o. & то & 0.004 \\
\hline .004 & TO & 0.005 \\
\hline 0.00 & то & 0.006 \\
\hline 0.006 & TO & 0.007 \\
\hline 0.007 & TO & 0.008 \\
\hline 01 & & \\
\hline
\end{tabular}

WEIGHTED AVERAGE

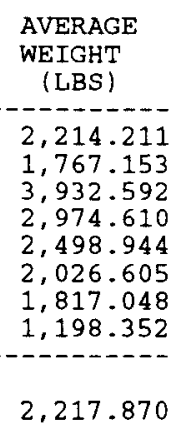

$2,217.870$

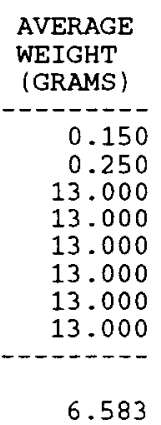

\begin{tabular}{l} 
AVERAGE \\
\hline 0.000 \\
0.000 \\
0.003 \\
0.004 \\
0.005 \\
0.006 \\
0.007 \\
0.011 \\
\hline 0.003
\end{tabular}

\begin{tabular}{cr}
$\begin{array}{c}\text { NUMBER OF } \\
\text { BOXES }\end{array}$ & $\begin{array}{c}\text { RUNNING } \\
\text { TOTAL }\end{array}$ \\
\hline 10 & 10 \\
2 & 12 \\
1 & 13 \\
1 & 14 \\
3 & 17 \\
5 & 22 \\
1 & 23 \\
1 & 24
\end{tabular}

24 
CONCENTRATION DISTRIBUTION (GRAMS PER POUNDS)

CONTENT: ALL

CONTENT CODES: ALL

\section{CONCENTRATION}

$0.000 \mathrm{E}+00$

3. $413 \mathrm{E}-05$

$4.472 \mathrm{E}-05$

$4.910 \mathrm{E}-05$

$6.202 \mathrm{E}-05$

1. $221 \mathrm{E}-04$

$1.375 \mathrm{E}-04$

1.399E-04

$1.411 \mathrm{E}-04$

$1.416 \mathrm{E}-04$

$1.462 \mathrm{E}-04$

$1.490 \mathrm{E}-04$

$1.518 \mathrm{E}-04$

$1.578 \mathrm{E}-04$

$1.633 \mathrm{E}-04$

$1.712 \mathrm{E}-04$

$2.065 \mathrm{E}-04$

$2.120 \mathrm{E}-04$

$2.177 \mathrm{E}-04$

$2.303 E-04$

2. $371 \mathrm{E}-04$

$2.458 \mathrm{E}-04$

$2.618 \mathrm{E}-04$

$2.689 \mathrm{E}-04$

$2.989 \mathrm{E}-04$

$3.291 \mathrm{E}-04$

$3.408 \mathrm{E}-04$

3. $513 \mathrm{E}-04$

$3.527 \mathrm{E}-04$

$3.656 \mathrm{E}-04$

$4.064 \mathrm{E}-04$

4. 344 E-04

$4.387 \mathrm{E}-04$

$4.709 \mathrm{E}-04$

$4.753 \mathrm{E}-04$

4.845E-04

$4.868 \mathrm{E}-04$

$4.886 \mathrm{E}-04$

$4.899 \mathrm{E}-04$

4. $910 \mathrm{E}-04$

4. $919 \mathrm{E}-04$

$4.927 \mathrm{E}-04$

4. $933 \mathrm{E}-04$

4. $938 \mathrm{E}-04$

$5.111 \mathrm{E}-04$

$5.119 \mathrm{E}-04$

$5.127 \mathrm{E}-04$

5.137E-04

$5.149 \mathrm{E}-04$

$5.163 E-04$

5.181E-04

$5.203 E-04$

5.231E-04

$5.270 \mathrm{E}-04$

5.291E-04

5.312E-04

$5.325 \mathrm{E}-04$

$5.337 \mathrm{E}-04$

5.366 E-04

$5.401 \mathrm{E}-04$

$5.444 \mathrm{E}-04$

$5.496 \mathrm{E}-04$

\begin{tabular}{|c|c|}
\hline $\begin{array}{c}\text { AVERAGE } \\
\text { WEIGHT } \\
\text { (LBS) }\end{array}$ & $\begin{array}{l}\text { AVERAGE } \\
\text { WEIGHT } \\
\text { (GRAMS) }\end{array}$ \\
\hline $\begin{array}{l}2,056.887 \\
2,929.704 \\
2,236.164 \\
2,036.586 \\
1,612.479 \\
1,637.427 \\
2,909.746 \\
2,859.852 \\
2,834.902 \\
2,824.925 \\
2,735.115 \\
2,685.220 \\
2,635.325 \\
2,535.535 \\
1,837.006 \\
2,335.955 \\
1,936.796 \\
1,886.901 \\
1,861.953 \\
1,837.006 \\
1,737.216 \\
1,687.322 \\
1,627.448 \\
1,527.658 \\
1,487.742 \\
1,338.057 \\
2,735.115 \\
2,934.694 \\
1,138.478 \\
2,834.904 \\
2,735.115 \\
2,460.692 \\
2,141.000 \\
2,735.115 \\
2,335.955 \\
2,735.115 \\
1,238.267 \\
1,437.846 \\
1,637.426 \\
1,837.005 \\
2,036.586 \\
2,236.164 \\
2,435.743 \\
2,635.324 \\
2,834.904 \\
2,934.692 \\
2,735.113 \\
2,535.532 \\
2,335.954 \\
2,136.375 \\
1,936.792 \\
1,737.215 \\
1,537.633 \\
1,338.056 \\
1,138.478 \\
2,834.902 \\
2,635.325 \\
938.898 \\
2,435.743 \\
2,236.164 \\
2,036.586 \\
1,837.006 \\
1,637.426\end{array}$ & $\begin{array}{l}0.000 \\
0.100 \\
0.100 \\
0.100 \\
0.100 \\
0.200 \\
0.400 \\
0.400 \\
0.400 \\
0.400 \\
0.400 \\
0.400 \\
0.400 \\
0.400 \\
0.300 \\
0.400 \\
0.400 \\
0.400 \\
0.400 \\
0.400 \\
0.400 \\
0.400 \\
0.400 \\
0.400 \\
0.400 \\
0.400 \\
0.900 \\
1.000 \\
0.400 \\
1.000 \\
1.000 \\
1.000 \\
0.930 \\
1.200 \\
1.100 \\
1.300 \\
0.600 \\
0.700 \\
0.800 \\
0.900 \\
1.000 \\
1.100 \\
1.200 \\
1.300 \\
1.400 \\
1.500 \\
1.400 \\
1.300 \\
1.200 \\
1.100 \\
1.000 \\
0.900 \\
0.800 \\
0.700 \\
0.600 \\
1.500 \\
1.400 \\
0.500 \\
1.300 \\
1.200 \\
1.100 \\
1.000 \\
0.900\end{array}$ \\
\hline
\end{tabular}

NUMBER OF RUNNING
BINS
TOTAL

CONCENTRATION

0.000

0.000

0.000

0.000

0.000

0.000

0.000

0.000

0.000

0.000

0.000

0.000

0.000

0.000

0.000

0.000

0.000

0.000

0.000

0.000

0.000

0.000

0.000

0.000

0.000

0.000

0.000

0.000

0.000

0.000

0.000

0.000

0.000

0.000

0.000

0.000

0.000

0.000

0.000

0.000

0.000

0.000

0.000

0.000

0.001

0.001

0.001

0.001

0.001

0.001

0.001

0.001

0.001

0.001

0.001

0.001

0.001

0.001

0.001

0.001

0.001

0.001

$-0-19$

$\begin{array}{ll}1 & 3 \\ 2 & 3\end{array}$

34

$1 \quad 36$

$1 \quad 37$

1238

$1 \quad 4$

42

43

44

45
46

47

50

51

52

55 
CONCENTRATION DISTRIBUTION (GRAMS PER POUNDS)

CONTENT: ALL

CONTENT CODES: ALL

\section{CONCENTRATION}

\section{$5.564 \mathrm{E}-04$}

$5.653 \mathrm{E}-04$

$6.532 \mathrm{E}-04$

$6.702 \mathrm{E}-04$

$6.955 \mathrm{E}-04$

$7.021 \mathrm{E}-04$

$7.621 \mathrm{E}-04$

$7.745 \mathrm{E}-04$

$8.261 \mathrm{E}-04$

$8.519 \mathrm{E}-04$

$8.819 \mathrm{E}-04$

$9.362 \mathrm{E}-04$

$9.838 \mathrm{E}-04$

$9.877 \mathrm{E}-04$

$9.882 \mathrm{E}-04$

$1.022 \mathrm{E}-03$

$1.058 \mathrm{E}-03$

$1.097 \mathrm{E}-03$

$1.129 \mathrm{E}-03$

$1.183 \mathrm{E}-03$

$1.188 \mathrm{E}-03$

$1.228 \mathrm{E}-03$

$1.232 \mathrm{E}-03$

$1.284 \mathrm{E}-03$

$1.291 \mathrm{E}-03$

$1.295 \mathrm{E}-03$

$1.404 \mathrm{E}-03$

$1.438 \mathrm{E}-03$

$1.518 \mathrm{E}-03$

$1.533 \mathrm{E}-03$

$1.609 \mathrm{E}-03$

$1.712 \mathrm{E}-03$

1.972E-03

$2.450 \mathrm{E}-03$

$2.450 \mathrm{E}-03$

$2.814 \mathrm{E}-03$

$3.392 \mathrm{E}-03$

$3.550 \mathrm{E}-03$

$3.576 \mathrm{E}-03$

$3.610 \mathrm{E}-03$

$3.642 \mathrm{E}-03$

$3.919 \mathrm{E}-03$

$3.944 \mathrm{E}-03$

$4.021 \mathrm{E}-03$

$4.022 \mathrm{E}-03$

$4.061 E-03$

$4.089 E-03$

$4.168 \mathrm{E}-03$

$4.191 E-03$

$4.229 \mathrm{E}-03$

$4.288 \mathrm{E}-03$

$4.419 \mathrm{E}-03$

$4.457 \mathrm{E}-03$

$4.515 \mathrm{E}-03$

$4.598 \mathrm{E}-03$

$4.681 \mathrm{E}-03$

$4.709 \mathrm{E}-03$

$4.795 \mathrm{E}-03$

$4.907 \mathrm{E}-03$

$4.941 E-03$

$4.964 \mathrm{E}-03$

$5.044 \mathrm{E}-03$

5. 181E-03

\begin{tabular}{cc}
$\begin{array}{c}\text { AVERAGE } \\
\text { WEIGHT }\end{array}$ & $\begin{array}{l}\text { AVERAGE } \\
\text { (LBS) }\end{array}$ \\
\hline WEIGHT \\
(GRAMS)
\end{tabular}

$1,437.845$

$1,238.267$

$1,837.006$

$2,834.904$

$1,437.847$

$2,136.375$

$1,837.006$

$1,936.796$

$1,936.796$

$2,934.694$

2, 834.904

$2,136.375$

$2,236.166$

$2,834.904$

$2,934.694$

$2,934.694$

$2,834.904$

$2,735.115$

$2,036.586$

$2,535.535$

$1,936.796$

$2,036.586$

$2,435.745$

$2,335.955$

$1,936.796$

$2,934.694$

$2,136.375$

$2,086.481$

$2,635.325$

$2,934.694$

$2,485.640$

$2,335.955$

$2,535.535$

$2,735.115$

$1,837.005$

$1,777.133$

589.634

$2,535.535$

$1,118.519$

1. 647.406

$2,934.692$

$2,535.535$

$2,834.904$

$2,735.115$

$2,216.207$

$2,934.694$

$2,735.113$

$2,934.694$

$2,435.745$

$2,635.324$

$2,036.586$

$2,535.533$

$2,834.904$

$2,435.744$

$2,136.375$

$2,335.955$

$2,335.955$

$2,934.693$

$2,934.694$

2. 236.164

$2,834.904$

1.737 .216

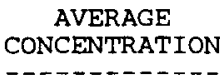

0.001

0.001

0.001

0.001

0.001

0.001

0.001

0.001

0.001

0.001

0.001

0.001

0.001

0.001

0.001

0.001

0.001

0.001

0.001

0.001

0.001

0.001

0.001

0.001

0.001

0.001

0.001

0.002

0.002

0.002

0.002

0.002

0.002

0.002

0.003

0.003

0.004

0.004

0.004

0.004

0.004

0.004

0.004

0.004

0.004

0.004

0.004

0.004

0.004

0.004

0.004

0.004

0.005

0.005

0.005

0.005

0.005

0.005

0.005

0.005

0.005

0.005

NUMBER OF RUNNING
BINS
TOTAL

10

278

278

281

282

283

284
285

287

288

289

290

291

292
293

295

296

297

299

300

301

302

303
304

305

306

307

308

309

310

311

313

314

317

318

319

320

321
365

366

371

372

373

374

376

381
382

383

386

387

389

390

392

393

394

395

397
398

404

405

406 
CONCENTRATION DISTRIBUTION

(GRAMS PER POUNDS)

CONTENT: ALL

CONTENT CODES : ALL

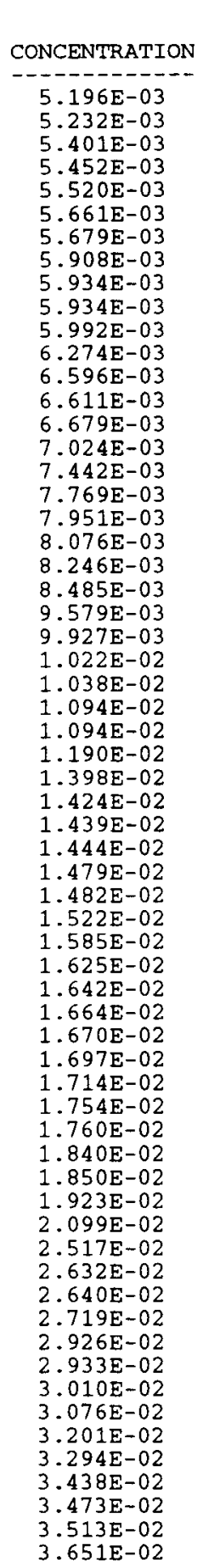

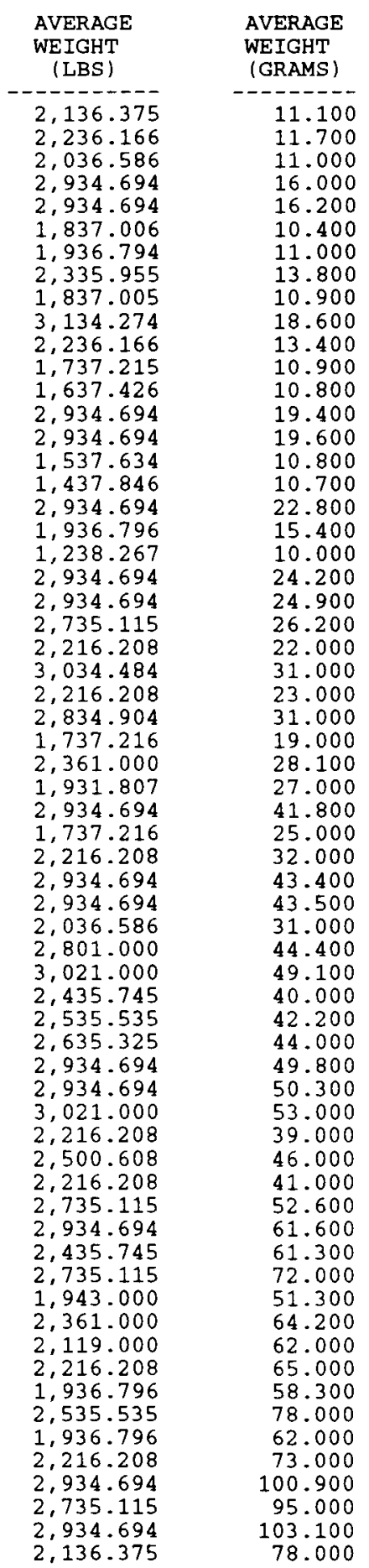

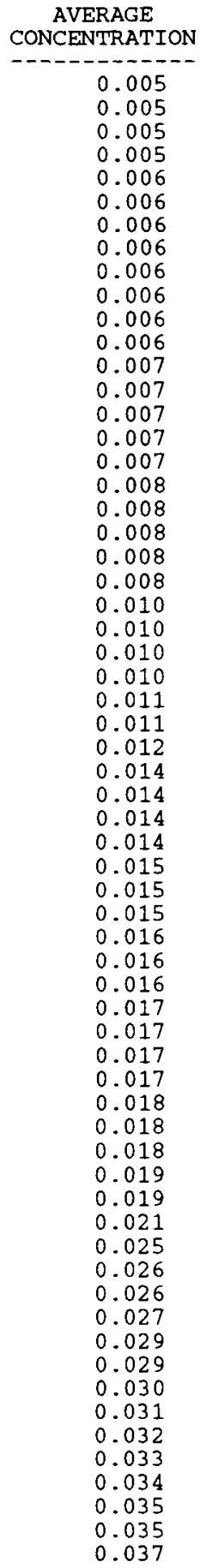

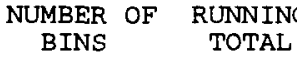

BINS TOTAL

- - - - - - - - - - - -


CONCENTRATION DISTRIBUTION (GRAMS PER POUNDS)

CONTENT: ALL CONTENT CODES: ALL

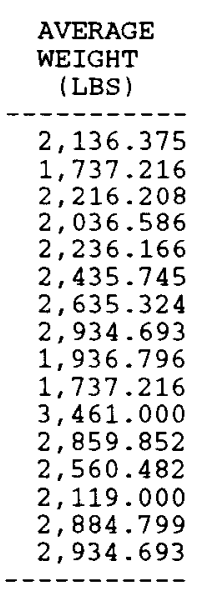

2.174 .655

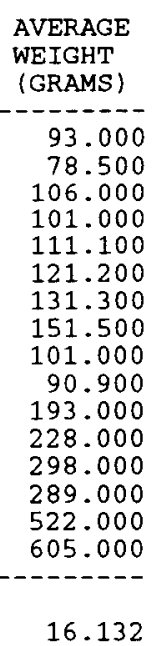

$\begin{array}{cr}\begin{array}{c}\text { NUMBER } \\ \text { BINS }\end{array} & \begin{array}{c}\text { RUNNING } \\ \text { TOTAL }\end{array} \\ -1 & 496 \\ 1 & 497 \\ 1 & 498 \\ 2 & 500 \\ 1 & 501 \\ 1 & 502 \\ 3 & 505 \\ 3 & 508 \\ 1 & 509 \\ 1 & 510 \\ 1 & 511 \\ 1 & 512 \\ 1 & 513 \\ 1 & 514 \\ 1 & 515 \\ 2 & 517 \\ ---- & \\ 517 & \end{array}$


APPENDIX E:

CALCULATIONAL CONFIGURATION OF EXISTING MORE HEAVILY LOADED DRUMS 


\section{WASTE CHARACTERIZED BY GRAPHITE WITH PLUTONIUM CONCENTRATIONS THAT EXCEED 37.5\% OF THE MINIMUM CRITICAL VALUE}

\begin{tabular}{|c|c|c|}
\hline $\begin{array}{c}\text { Drum } \\
\text { No. }\end{array}$ & $\begin{array}{c}\text { 2s0 Pu Concentration } \\
\text { (g Pu/b matrix) }\end{array}$ & $\begin{array}{c}\text { Number of } \\
\text { drums }\end{array}$ \\
\hline 1 & 1.27 & 6 \\
\hline 2 & 0.99 & 1 \\
\hline 3 & 0.85 & 2 \\
\hline 4 & 0.65 & 4 \\
\hline 5 & 0.54 & 6 \\
\hline 6 & 0.44 & 29 \\
\hline 7 & 0.34 & 60 \\
\hline 8 & 0.24 & 156 \\
\hline 9 & 0.14 & 506 \\
\hline 10 & 0.10 & 1388 \\
\hline $11^{*}$ & 0.15 & 39 \\
\hline
\end{tabular}

a Drum Type 11 contains $\mathrm{SiO}_{2}$ at $75 \%$ of the critical concentration This drum type was used to complete the cubic configuration of the array

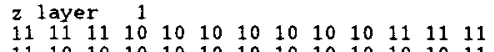
11101010101010101010101011 11101010101010101010101011 10101010101010101010101010 10101010101010101010101010

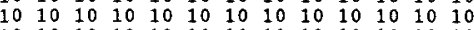
$1010101010 \quad 1010101010101010$ 10101010101010101010101010 10 10 10 10 10 10 10 10 10 10 10 10 10 10 10 10 10 10 10 10 10 10 10 10 10 10 11. 101010 10 10 10 10 10 10 10 10 10 10 10 10 10

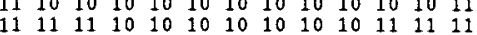

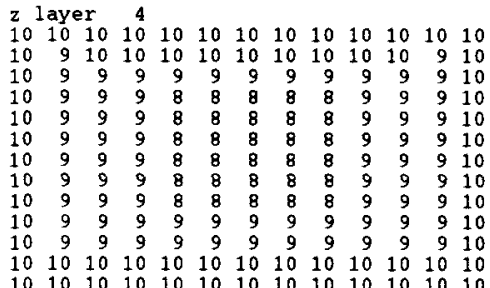

2 layer 2

$10 \quad 10 \quad 10 \quad 10 \quad 10 \quad 10 \quad 1010$ $\begin{array}{llllllllllll}10 & 10 & 10 & 10 & 10 & 10 & 10 & 10 & 10 & 10 & 10 & 10\end{array}$

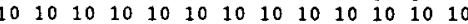
$\begin{array}{lllllllllllll}10 & 10 & 10 & 10 & 10 & 10 & 10 & 10 & 10 & 10 & 10 & 10 & 10\end{array}$

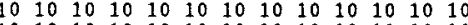
$10101010101010101010101010 \quad 10$

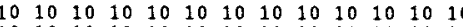
$1010101010 \quad 10 \quad 10 \quad 1010101010 \quad 1010$ 101010101010 10 101010101010 1010 10 10 10 10 10 10 10 10 10101010 101010 10 10 10 10 10 10 10 10 1010 $\begin{array}{lllllllllllll}10 & 10 & 10 & 10 & 10 & 10 & 10 & 10 & 10 & 10 & 10 & 10 & 10 \\ 10 & 10 & 10 & 10 & 10 & 10 & 10 & 10 & 10 & 10 & 10 & 10 & 10\end{array}$

2 layer 5

10101010101010101010101010

10101010101010101010101010

$\begin{array}{lllllllllllll}10 & 10 & 9 & 9 & 9 & 9 & 9 & 9 & 9 & 9 & 9 & 10 & 10\end{array}$

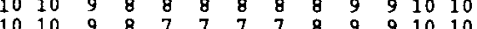

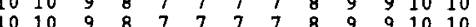

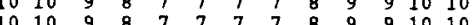

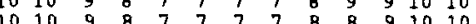

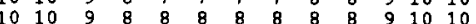
$\begin{array}{lllllllllllllll}10 & 10 & 9 & 9 & 9 & 9 & 9 & 9 & 9 & 8 & 9 & 10 & 10\end{array}$ $\begin{array}{llllllllllllll}10 & 10 & 9 & 9 & 9 & 9 & 9 & 9 & 9 & 9 & 9 & 10 & 10\end{array}$ $\begin{array}{lllllllllllll}10 & 10 & 10 & 10 & 10 & 10 & 10 & 10 & 9 & 10 & 10 & 10 & 10 \\ 10 & 10 & 10 & 10 & 10 & 10 & 10 & 10 & 10 & 10 & 10 & 10 & 10\end{array}$

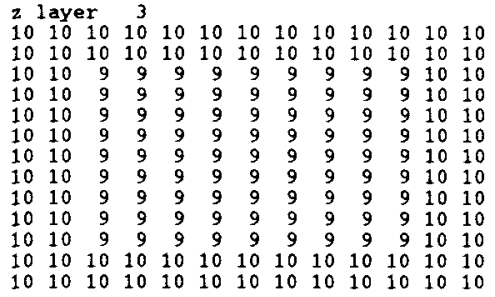

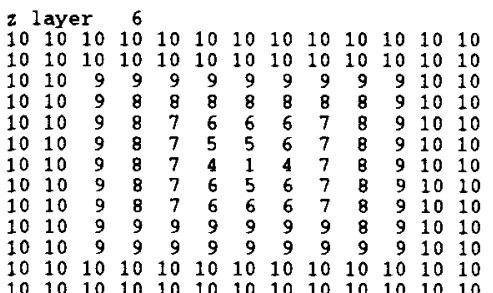



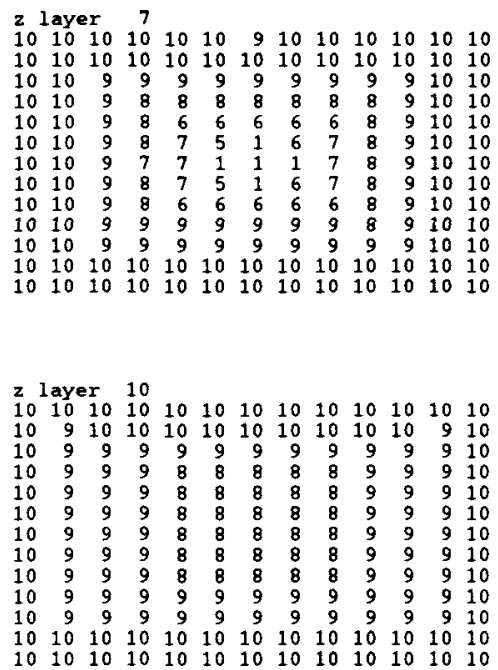

2 layer 13

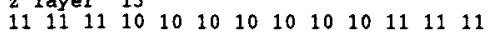
$\begin{array}{lllllllllllll}11 & 10 & 10 & 10 & 10 & 10 & 10 & 10 & 10 & 10 & 10 & 10 & 11\end{array}$ $\begin{array}{lllllllllllll}11 & 10 & 10 & 10 & 10 & 10 & 10 & 10 & 10 & 10 & 10 & 10 & 11\end{array}$ $\begin{array}{lllllllllllllll}10 & 10 & 10 & 10 & 10 & 10 & 10 & 10 & 10 & 10 & 10 & 10 & 10\end{array}$ $\begin{array}{lllllllllllll}10 & 10 & 10 & 10 & 10 & 10 & 10 & 10 & 10 & 10 & 10 & 10 & 10\end{array}$ $\begin{array}{lllllllllllll}10 & 10 & 10 & 10 & 10 & 10 & 10 & 10 & 10 & 10 & 10 & 10 & 10\end{array}$ $10101010 \quad 10 \quad 101010 \quad 1010 \quad 10 \quad 1010$ $\begin{array}{lllllllllllll}10 & 10 & 10 & 10 & 10 & 10 & 10 & 10 & 10 & 10 & 10 & 10 & 10\end{array}$

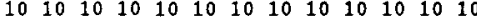
$\begin{array}{lllllllllllll}10 & 10 & 10 & 10 & 10 & 10 & 10 & 10 & 10 & 10 & 10 & 10 & 10\end{array}$ 11 10 10 10 10 10 10 10 10 10 10 10 10 10 10 10 10

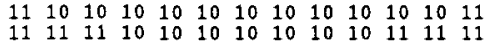

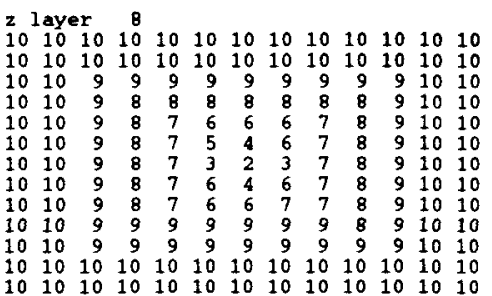

2 layer 9 $\begin{array}{lllllllllllll}10 & 10 & 10 & 10 & 10 & 10 & 10 & 10 & 10 & 10 & 10 & 10 & 10\end{array}$ $\begin{array}{ccccccccccccc}10 & 10 & 10 & 10 & 10 & 10 & 10 & 10 & 10 & 10 & 10 & 10 & 10 \\ 10 & 10 & 9 & 9 & 9 & 9 & 9 & 9 & 9 & 9 & 9 & 10 & 10\end{array}$ $\begin{array}{llllllllllllll}10 & 10 & 9 & 8 & 8 & 8 & 8 & 8 & 9 & 9 & 9 & 10 & 10 & 10\end{array}$

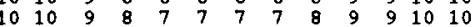
10

921010 $\begin{array}{llllllllllllll}10 & 10 & 9 & 8 & 7 & 7 & 7 & 7 & 8 & 9 & 9 & 10 & 10 & 70\end{array}$ $\begin{array}{llllllllllll}10 & 10 & 9 & 8 & 7 & 7 & 7 & 8 & 8 & 9 & 10 & 10\end{array}$ $\begin{array}{lllllllllllll}10 & 10 & 9 & 8 & 8 & 8 & 8 & 8 & 8 & 9 & 9 & 10 & 10 \\ 0 & 9 & 9 & 9 & 9 & 9 & 9 & 10 & 10\end{array}$

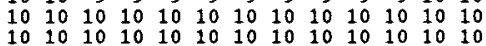

2 layer 11

$10 \quad 1010 \quad 10 \quad 10 \quad 1010 \quad 1010 \quad 10 \quad 10 \quad 10 \quad 10$ $\begin{array}{lllllllllllllllllllll}10 & 10 & 10 & 10 & 10 & 10 & 10 & 10 & 10 & 10 & 10 & 10 & 10\end{array}$

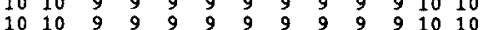
101009909000 1010099000 101009090

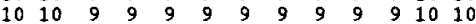
$\begin{array}{llllllllllllll}10 & 10 & 9 & 9 & 9 & 9 & 9 & 9 & 9 & 9 & 9 & 10 & 10\end{array}$ $\begin{array}{lllllllllllll}10 & 10 & 9 & 9 & 9 & 9 & 9 & 9 & 9 & 9 & 9 & 10 & 10\end{array}$ $10 \quad 10 \quad 10 \quad 10 \quad 10 \quad 10 \quad 10 \quad 10 \quad 10 \quad 10 \quad 10 \quad 10 \quad 10$ $10 \quad 10 \quad 10 \quad 10 \quad 10 \quad 10 \quad 10 \quad 10 \quad 10 \quad 10 \quad 10 \quad 10 \quad 10$ $z$ layer 12

$101010 \quad 1010 \quad 1010 \quad 1010 \quad 10 \quad 1010 \quad 10$ $1010101010 \quad 10 \quad 10 \quad 101010 \quad 10 \quad 1010$ $101010 \quad 10 \quad 1010 \quad 10 \quad 101010 \quad 10 \quad 1010$ $10101010101010 \quad 101010101010$ 10101010101010 10 10 10 10 10 10 101010101010 10 10 10 10 10 10 10 10101010101010101010101010 10101010101010101010101010 10101010 10 10 10 1010101010 10101010101012101010101010

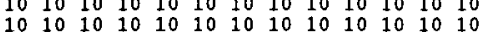
10101010 10 10 10 10 10 10 10 10 


\section{WASTE CHARACTERIZED BY $\mathrm{SIO}_{2}$ WITH PLUTONIUM CONCENTRATIONS THAT EXCEED $37.5 \%$ OF THE MINIMUM CRITICAL VALUE}

\begin{tabular}{|c|c|c|}
\hline $\begin{array}{c}\text { Drum } \\
\text { No. }\end{array}$ & $\begin{array}{c}250 \text { Pu Concentration } \\
\text { (g Pu/b matrix) }\end{array}$ & $\begin{array}{c}\text { Number of } \\
\text { drums }\end{array}$ \\
\hline 1 & 2.03 & 2 \\
\hline 2 & 1.31 & 116 \\
\hline 3 & 0.95 & $25^{\circ}$ \\
\hline 4 & 0.74 & $33^{b}$ \\
\hline 5 & 0.55 & $171^{\circ}$ \\
\hline 6 & 0.24 & 142 \\
\hline 7 & 0.15 & 526 \\
\hline $8^{d}$ & 0.15 & 316 \\
\hline
\end{tabular}

a Number of drums includes those having ${ }^{200} \mathrm{Pu}$ concentrations of 095 and 085

b Number of drums includes those having pu concentrations of 074 and 065

c Number of drums includes those having ${ }^{200} \mathrm{Pu}$ concentrations of 055,044 and 034

d Drum Type 8 contains $\mathrm{SiO}_{2}$ at $75 \%$ of the critical concentration This drum type

was used to complete the cubic configuration of the array
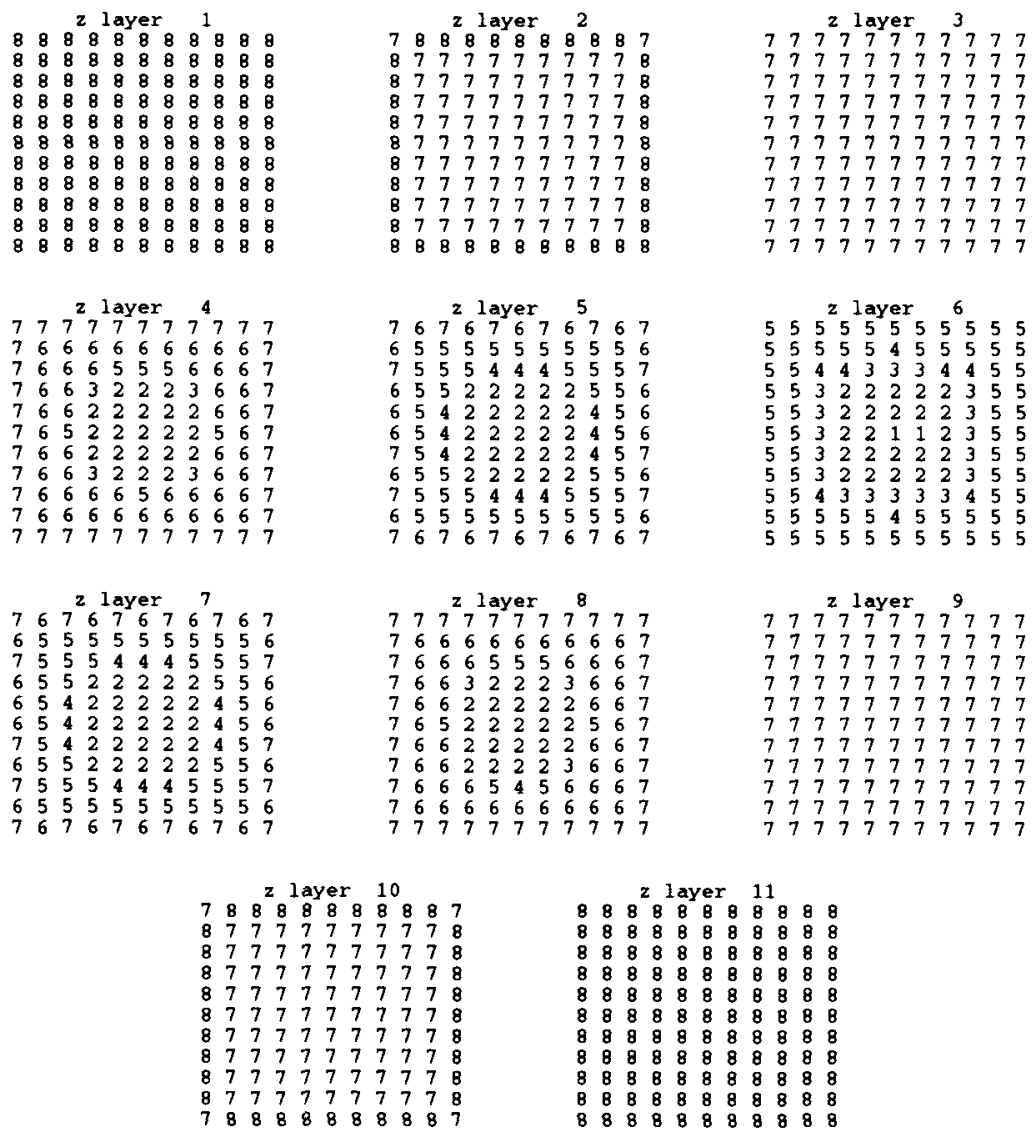
WASTE CHARACTERIZED BY MGO WITH PLUTONIUM CONCENTRATIONS THAT EXCEED $37.5 \%$ OF THE MINIMUM CRITICAL VALUE

\begin{tabular}{|c|c|c|}
\hline $\begin{array}{c}\text { Drum } \\
\text { No. }\end{array}$ & $\begin{array}{c}\text { 2s0 Pu Concentration } \\
\text { (g Pu/b matrix) }\end{array}$ & $\begin{array}{c}\text { Number of } \\
\text { drums }\end{array}$ \\
\hline 1 & 2.03 & 2 \\
\hline 2 & 1.34 & 116 \\
\hline 3 & 0.95 & $25^{*}$ \\
\hline 4 & 0.74 & $33^{b}$ \\
\hline 5 & 0.55 & $171^{\circ}$ \\
\hline 6 & 0.24 & 142 \\
\hline 7 & 0.15 & 346 \\
\hline 8 & 0.10 & 367 \\
\hline $9^{d}$ & 0.15 & 129 \\
\hline
\end{tabular}

a Number of drums includes those having ${ }^{230} \mathrm{Pu}$ concentrations of 0.5 and 085

b Number of drums inciudes those having ${ }^{200} \mathrm{Pu}$ concentrations of 074 and 065

c Number of drums includes those having ${ }^{290} \mathrm{Pu}$ concnetrations of 055,044 and 034

d Drum Type 9 contains $\mathrm{S}_{2} \mathrm{O}_{2}$ at $75 \%$ of the critical concentration This drum type

was used to complete the cubic configuration of the array
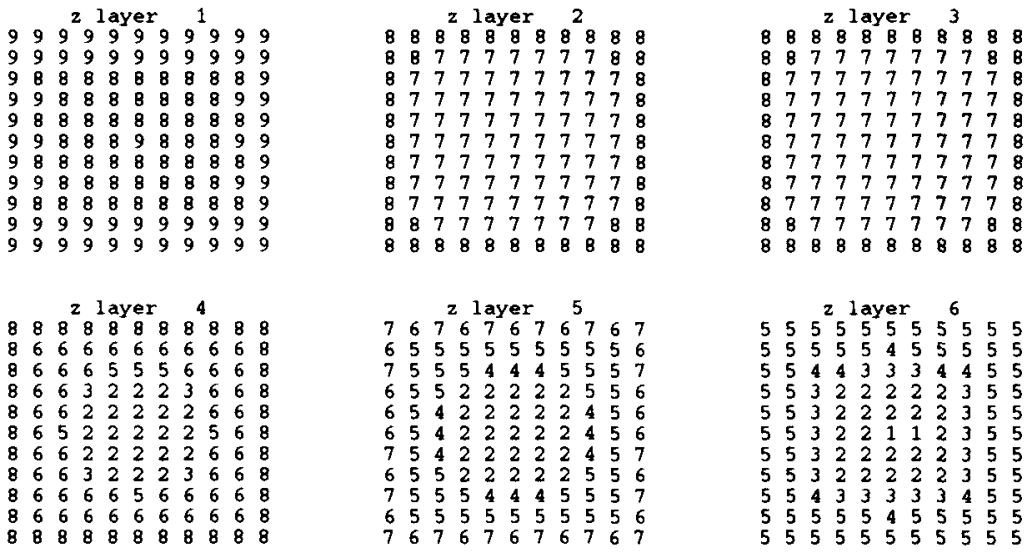

$767^{2}$ layer 7

2 layer 8

$\begin{array}{lllllllllll}7 & 6 & 7 & 6 & 7 & 6 & 7 & 6 & 7 & 6 & 7 \\ 6 & 5 & 5 & 5 & 5 & 5 & 5 & 5 & 5 & 5 & 6 \\ 7 & 5 & 5 & 5 & 4 & 4 & 4 & 5 & 5 & 5 & 7\end{array}$

$\begin{array}{lllllllllllll}6 & 5 & 5 & 2 & 2 & 2 & 2 & 2 & 5 & 5 & 5 \\ 6 & 5 & 0\end{array}$

$\begin{array}{llllllllllll}6 & 5 & 4 & 2 & 2 & 2 & 2 & 2 & 4 & 5 & 6 \\ 6 & 6 & 4 & 2 & 2 & 2 & 2 & 2 & 4 & 5 & 6\end{array}$

$\begin{array}{lllllllllll}6 & 5 & 4 & 2 & 2 & 2 & 2 & 2 & 4 & 5 & 6 \\ 7 & 5 & 4 & 2 & 2 & 2 & 2 & 2 & 4 & 5 & 7\end{array}$

$\begin{array}{llllllllllll}6 & 5 & 5 & 2 & 2 & 2 & 2 & 2 & 5 & 5 & 6 \\ 7 & 5 & 5 & 5 & 4 & 4 & 4 & 5 & 5 & 5 & 7\end{array}$

$\begin{array}{llllllllllll}6 & 5 & 5 & 5 & 5 & 5 & 5 & 5 & 5 & 5 & 6 \\ 7 & 6 & 7 & 6 & 7 & 6 & 7 & 6 & 7 & 6 & 7\end{array}$

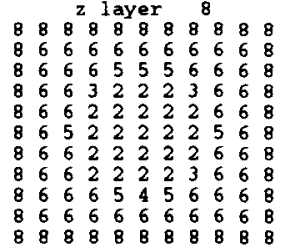

2 layer 9

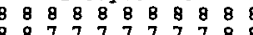

$\begin{array}{lllllllllll}8 & 8 & 7 & 7 & 7 & 7 & 7 & 7 & 7 & 8 & 8 \\ 8 & 7 & 7 & 7 & 7 & 7 & 7 & 7 & 7 & 7 & 8 \\ 8 & 8 & 7\end{array}$

87777777778

8777777777778

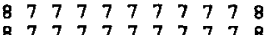

87777777778

8777777777778
877777779798

87777777778

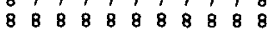



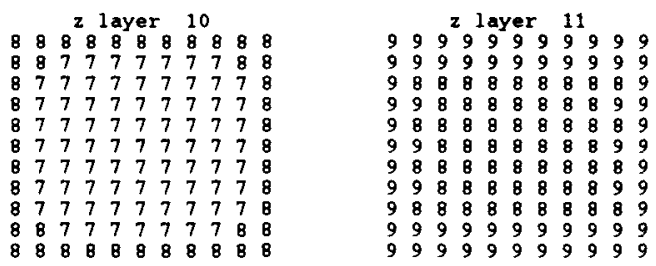

\section{WASTE CHARACTERIZED BY CELLULOSE WITH PLUTONIUM CONCENTRATIONS THAT EXCEED $37.5 \%$ OF THE MINIMUM CRITICAL VALUE}

\begin{tabular}{|c|c|c|}
\hline $\begin{array}{c}\text { Dnum } \\
\text { No. }\end{array}$ & $\begin{array}{c}\text { 290 Pu Concentration } \\
\text { (g Pu/b matrix) }\end{array}$ & $\begin{array}{c}\text { Number of } \\
\text { drums }\end{array}$ \\
\hline 1 & 6.72 & 1 \\
\hline 2 & 5.51 & 1 \\
\hline 3 & 4.64 & 2 \\
\hline 4 & 3.38 & 9 \\
\hline 5 & 2.32 & 44 \\
\hline 6 & 1.39 & 427 \\
\hline 7 & 0.15 & 245 \\
\hline
\end{tabular}

a Drum Type 7 comtains $\mathrm{SIO}_{2}$ at $75 \%$ of the ertical concentration This drum type was used to complete the cubic configuration of the array

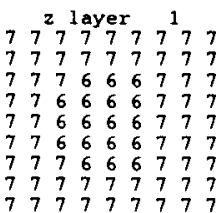

772 layer 4 777760669777 $\begin{array}{llllllllll}7 & 6 & 6 & 6 & 6 & 6 & 6 & 6 & 7 \\ 7 & 6 & 6 & 5 & 5 & 5 & 6 & 6 & 7\end{array}$

666555455606

$6 \begin{array}{llllllll}6 & 5 & 4 & 4 & 4 & 5 & 6 & 6\end{array}$

$\begin{array}{llllllllll}6 & 6 & 5 & 5 & 5 & 5 & 5 & 6 & 6 \\ 7 & 6 & 6 & 6 & 6 & 6 & 6 & 6 & 7\end{array}$

$76 \begin{array}{lllllllll}7 & 6 & 6 & 6 & 6 & 6 & 6 & 6 & 7 \\ 7 & 6 & 6 & 6 & 6 & 6 & 6 & 6 & 7\end{array}$

$\begin{array}{lllllllll}7 & 6 & 6 & 6 & 6 & 6 & 6 & 6 & 7 \\ 7 & 7 & 7 & 6 & 6 & 6 & 7 & 7 & 7\end{array}$

7 layer 7

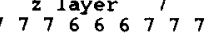

$\begin{array}{llllllllll}7 & 6 & 6 & 6 & 6 & 6 & 6 & 6 & 7\end{array}$

$\begin{array}{lllllllll}7 & 6 & 6 & 6 & 6 & 6 & 6 & 6 & 7 \\ 6 & 6 & 6 & 6 & 6 & 6 & 6 & 6 & 6\end{array}$

$\begin{array}{llllllllll}6 & 6 & 6 & 6 & 6 & 6 & 6 & 6 & 6\end{array}$

$\begin{array}{lllllllll}6 & 6 & 6 & 6 & 6 & 6 & 6 & 6 & 6\end{array}$

$\begin{array}{lllllllll}7 & 6 & 6 & 6 & 6 & 6 & 6 & 6 & 7 \\ 7 & 7 & 7 & 6 & 6 & 6 & 6 & 6 & 7\end{array}$
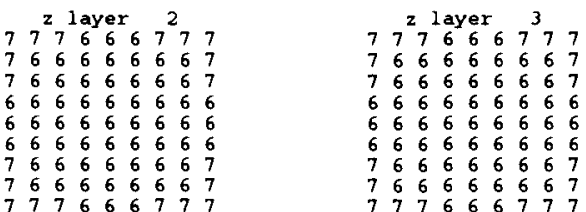

2 layer 5 $\begin{array}{llllllllll}6 & 6 & 6 & 6 & 6 & 6 & 6 & 6 & 6\end{array}$ $\begin{array}{lllllllll}6 & 6 & 6 & 6 & 6 & 6 & 6 & 6 & 6 \\ 6 & 6 & 6 & 5 & 5 & 5 & 6 & 6 & \end{array}$ $\begin{array}{lllllllll}6 & 6 & 5 & 5 & 2 & 5 & 5 & 6 & 6\end{array}$ $\begin{array}{llllllllll}6 & 6 & 5 & 3 & 1 & 3 & 5 & 6 & 6\end{array}$ $6 \begin{array}{lllllllll}6 & 6 & 5 & 5 & 5 & 5 & 6 & 6 \\ 6 & 6 & 6 & 5 & 5 & 5 & 6 & 6 & 6\end{array}$ $\begin{array}{lllllllll}6 & 6 & 6 & 5 & 5 & 5 & 6 & 6 & 6\end{array}$ $\begin{array}{lllllllll}6 & 6 & 6 & 6 & 6 & 6 & 6 & 6 & 6 \\ 6 & 6 & 6 & 6 & 6 & 6 & 6 & 6 & 6\end{array}$

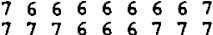

2 layer 6 766 765655555667 $\begin{array}{lllllllll}6 & 6555 & 4 & 5 & 5 & 66\end{array}$

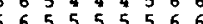
76666666667 $\begin{array}{lllllllll}7 & 6 & 6 & 6 & 6 & 6 & 6 & 6 & 7 \\ 7 & 7 & 7 & 6 & 6 & 6 & 7 & 7 & 7\end{array}$

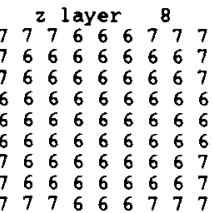

$77_{7}^{2}$ layer 997 777777777

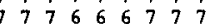
$\begin{array}{lllllllll}776 & 6 & 6 & 6 & 7 & 777\end{array}$ 7776666660677 77666666777 $\begin{array}{lllllllll}7 & 7 & 7 & 6 & 6 & 6 & 7 & 7 & 7 \\ 7 & 7 & 7 & 7 & 7 & 7 & 7\end{array}$ 
WASTE CHARACTERIZED BY CONCRETE WITH PLUTONIUM CONCENTRATIONS THAT EXCEED 37.5\% OF THE MINIMUM CRITICAL VALUE

\begin{tabular}{|c|c|c|}
\hline $\begin{array}{c}\text { Drum } \\
\text { No. }\end{array}$ & $\begin{array}{c}\text { 250 Pu Concentration } \\
\text { (g Pu/b matrix) }\end{array}$ & $\begin{array}{c}\text { Number of } \\
\text { drums }\end{array}$ \\
\hline \hline 1 & 1.13 & 138 \\
\hline $2^{a}$ & 0.15 & 78 \\
\hline
\end{tabular}

a Drum Type 2 contains $\mathrm{SiO}_{2}$ at $75 \%$ of the critical concentration This drum type was used to complete the cubic contiguration of the array
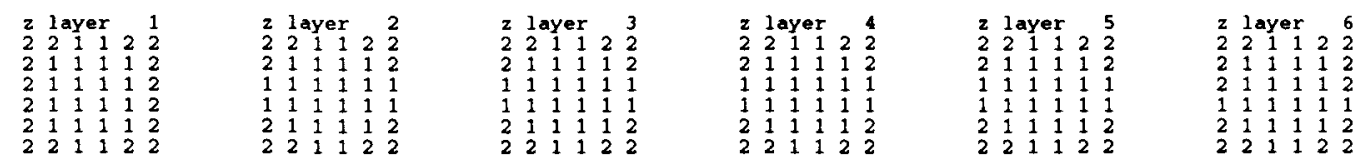

WASTE CHARACTERIZED BY ALUMINUM WITH PLUTONIUM CONCENTRATIONS THAT EXCEED $37.5 \%$ OF THE MINIMUM CRITICAL VALUE

\begin{tabular}{|c|c|c|}
\hline $\begin{array}{c}\text { Drum } \\
\text { No. }\end{array}$ & $\begin{array}{c}\text { 2sepu Concentration } \\
\text { (g Pu/lb matrix) }\end{array}$ & $\begin{array}{c}\text { Number of } \\
\text { drums }\end{array}$ \\
\hline \hline 1 & 3.44 & 209 \\
\hline 2 & 0.15 & 7 \\
\hline
\end{tabular}

a Drum Type 2 contains $\mathrm{SiO}_{2}$ at $75 \%$ of the critical concentration This drum type was used to complete the cubic configuration of the array
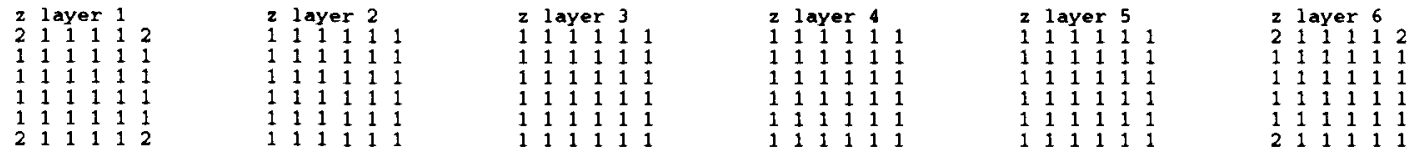
WASTE CHARACTERIZED BY AL $\mathrm{O}_{3}$ WITH PLUTONIUM CONCENTRATIONS

THAT EXCEED $37.5 \%$ OF THE MINIMUM CRITICAL VALUE

\begin{tabular}{|c|c|c|}
\hline $\begin{array}{c}\text { Drum } \\
\text { No. }\end{array}$ & $\begin{array}{c}{ }^{230} \mathrm{Pu} \text { Concentration } \\
\text { (g Pu/b matrix) }\end{array}$ & $\begin{array}{c}\text { Number of } \\
\text { drums }\end{array}$ \\
\hline 1 & 0.95 & 136 \\
\hline $2^{*}$ & 0.15 & 80 \\
\hline
\end{tabular}

a Drum Type 2 contains $\mathrm{SiO}_{2}$ at $75 \%$ of the critical concentration This drum type was used to complete the cubic configuration of the array
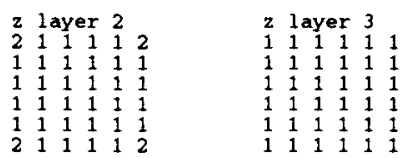

\begin{tabular}{llllll} 
z & \multicolumn{4}{c}{ layer } & 4 \\
1 & 1 & 1 & 1 & 1 & 1 \\
1 & 1 & 1 & 1 & 1 & 1 \\
1 & 1 & 1 & 1 & 1 & 1 \\
1 & 1 & 1 & 1 & 1 & 1 \\
1 & 1 & 1 & 1 & 1 & 1 \\
1 & 1 & 1 & 1 & 1 & 1
\end{tabular}

\begin{tabular}{llllll}
$\mathbf{2}$ & \multicolumn{6}{l}{ layer } & 5 & \\
2 & 1 & 1 & 1 & 1 & 2 \\
1 & 1 & 1 & 1 & 1 & 1 \\
1 & 1 & 1 & 1 & 1 & 1 \\
1 & 1 & 1 & 1 & 1 & 1 \\
1 & 1 & 1 & 1 & 1 & 1 \\
2 & 1 & 1 & 1 & 1 & 2
\end{tabular}

z layer 6

$\begin{array}{llllll}2 & 2 & 2 & 2 & 2\end{array}$ 
APPENDIX F:

INDEPENDENT REVIEW 
Date: October 26, 1993

To: $\quad$ J. B. Briggs, MS 3890

From: $\quad$ H. A. Worle, MS 3960

Subject: INDEPENDENT REVIEW OF THE CRITICALITY SAFETY EVALUATION FOR TRU WASTE IN STORAGE AT THE RWMC - WORLE-07-93

Attached is the summary of my review of the Criticality Safety Evaluation (CSE) for transuranic waste in storage at the Radioactive Waste Management Complex. The independent calculations in this review verify those contained in the CSE. The review verifies that modelling in the CSE is adequately conservative. Editorial and other verbal comments have been forwarded to you eartier and are appropriately addressed in the latest revision of the draft CSE. The subject CSE is a fine piece of work, and this reviewer concurs with its findings.

Attachment:

As Stated

cc: R. L. Nitschke, MS 3960

G. J. Briscoe,

H. A. Worle File, MS 3960

Central Files, MS 1651 
Attachment

October 26, 1993

Worle-07-93

Page 1 of 2

\section{INDEPENDENT REVIEW}

OF THE

\section{CRITICALITY SAFETY EVALUATION FOR TRU WASTE IN STORAGE AT THE RWMC}

Criticality safety calculations for the storage of transuranic-contaminated (TRU) waste have been performed and reported. ${ }^{\prime}$ Reference 1 constitutes the primary Criticality Safety Evaluation (CSE) for this waste storage. EG\&G Idaho, Inc. Company Procedure 7.2 requires the performance of an Independent Criticality Analysis (ICA) "to verify calculations and assumptions made by the author of the CSE." The CSE includes a multi-code comparison as part of the code validation and verification. Calculations with different criticality computer codes and nuclear cross-section libraries were performed by different individuals within the performing organization. It has been concluded that many of the essential requirements for an ICA have already been fulfilled and are incorporated into the CSE. Therefore, a full ICA is not required. A thorough review, including a few key independent computer calculations, has been performed and is reported here. The author of this review has been in contact with the authors of the primary CSE throughout the review process. Significant findings during the review have been passed on to the primary CSE authors, and have led to modifications of that document in a few cases. This review methodology has been judged to be the most appropriate and efficient way to comply with the independent review requirement cited above.

The basis for the criticality safety approach used in the primary CSE is to determine critical concentrations of Pu-239 in infinite systems of various waste matrices. These calculations have been independently repeated for this review. The calculations were performed with a personal computer version of the SCALE $4^{2}$ system of computer codes. The KENO-V.a computer code within that system was used, either as a stand-alone code with the 16-energy group cross-section library that is included with this code, or as part of the Criticality Safety Analytical Sequence (CSAS25), which allows the use of a 27-energy group cross-section library based on ENDF/B-IV (Evaluated Nuclear Data File/B-IV) cross-sections. Nine waste matrices were investigated: Water, polyethylene, cellulose, concrete, aluminum metal, aluminum oxide, silicon oxide, magnesium oxide, and graphite (water was later eliminated as a matrix). In most cases, the critical Pu-239 concentration is very close for the two calculational tools used. However, the metal oxides show a significant difference, with the calculations using the 27-group cross-sections yielding lower critical concentrations than the calculations using the Hansen-Roach library. Table 1 shows the results of these calculations and the comparative values from the primary CSE. The independently calculated Pu-239 concentrations show good agreement with the infinite system critical concentrations found in the primary CSE.

Computer input listings for many of the calculations reported in the various tables of the CSE have been reviewed. In one case, an error was found, leading to a recalculation of that case. Dimensions of realistic waste drum models used in certain calculations in the CSE were reviewed and found to be correct. A few independent calculations, other than those for infinite system critical concentrations discussed above, were performed for this review. The 
results, in all cases showed good agreement with those reported in the CSE. Constituent atom densities for many calculations reported in the CSE are listed in that document's Appendix A. Check calculations of those atom densities were performed, and close agreement was found in all cases.

Other reviews performed include an editorial review. Comments forwarded to the authors of the primary CSE have been incorporated into that document to improve its clarity.

It is the conclusion of this review that the results reported in Reference 1 are correct and that the primary CSE provides an adequate basis for a determination of criticality safety of the TRU waste stored at the Radioactive Waste Management Complex.

Table 1. Results of Independent Calculations of Critical Concentrations of Pu-239 in Various Matrices.

\begin{tabular}{|c|c|c|c|c|}
\hline \multirow[b]{2}{*}{ Matrix } & \multirow[b]{2}{*}{ Density $\left(\mathrm{g} / \mathrm{cm}^{3}\right)$} & \multicolumn{3}{|c|}{ Critical Pu-239 Concentrations (g per lb matrix) } \\
\hline & & H-R 16-group & 27-group & From Reference 1 \\
\hline Water & 1.0 & 3.18 & & 3.2 \\
\hline Polyethylene & 0.92 & 4.12 & & 4.12 \\
\hline Cellulose & 0.64 & 1.79 & 1.79 & 1.78 \\
\hline Aluminum & 2.70 & 1.10 & 1.09 & 1.10 \\
\hline Concrete & 2.37 & 0.73 & 0.75 & 0.75 \\
\hline $\mathrm{Al}_{2} \mathrm{O}_{3}$ & 3.695 & 0.37 & 0.308 & 0.31 \\
\hline $\mathrm{SiO}_{2}$ & 2.32 & 0.228 & 0.197 & 0.20 \\
\hline $\mathrm{MgO}$ & 3.58 & 0.14 & 0.12 & 0.12 \\
\hline Graphite & 1.6 & 0.0258 & 0.0246 & 0.0260 \\
\hline
\end{tabular}

\section{REFERENCES}

1. Maria E. Shaw, et al., Criticality Safety Evaluation for TRU Waste in Storage at the RWMC, EGG-NRE-10754, EG\&G Idaho, Inc., October 1993.

2. SCALE: A Modular Code System for Performing Standardized Computer Analyses for Licensing Evaluation, RSIC Computer Code Collection, CCC-545, NUREG/CR-0200, Rev. 4, ORNL/NUREG/CSD-2/R4, Oak Ridge National Laboratory. 


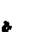

